National Water-Quality Assessment Program

\title{
Quality of Groundwater in the Denver Basin Aquifer System, Colorado, 2003-5
}

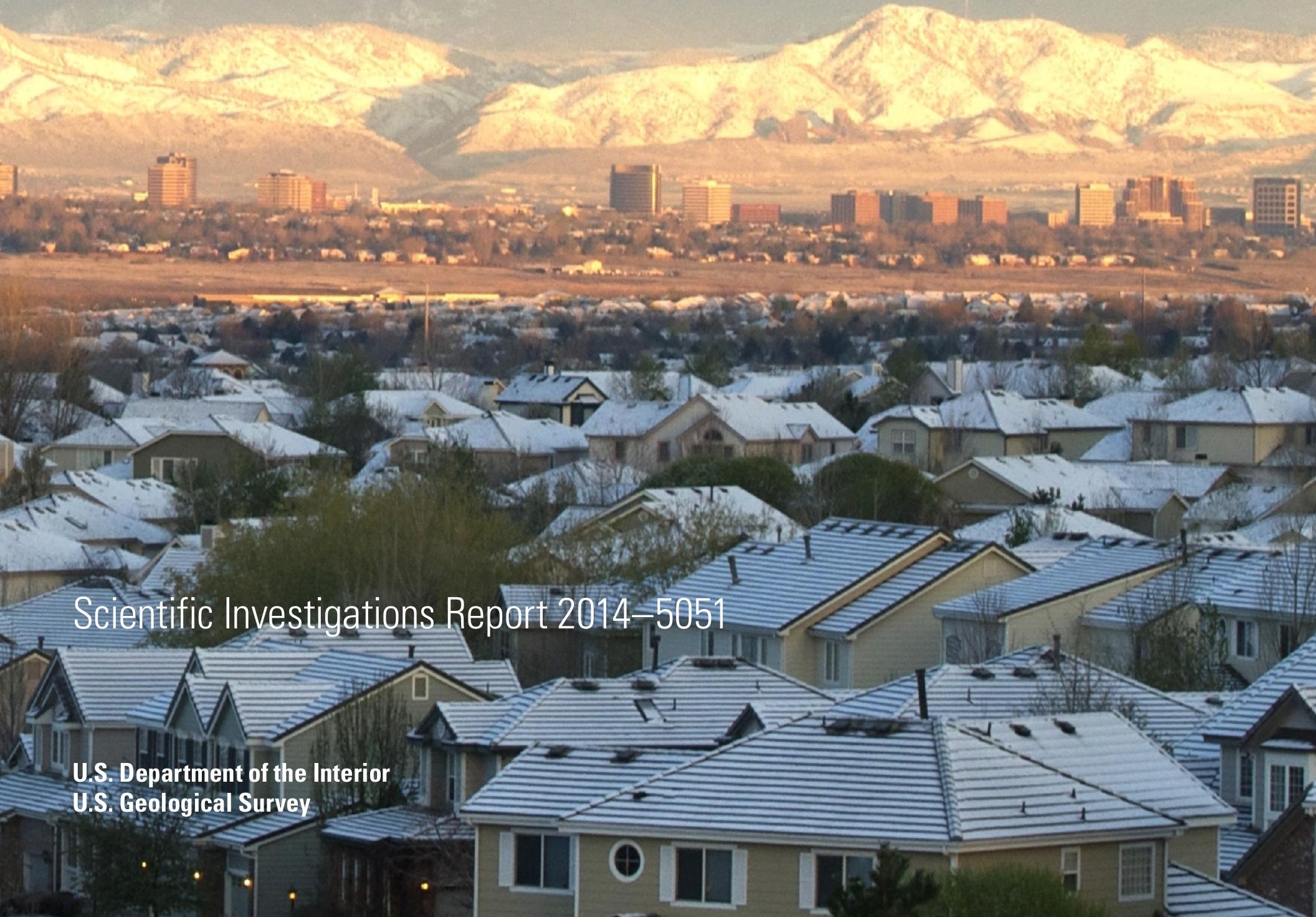


Cover, An April dusting of snow covers the south metropolitan area of Denver, Colorado, and the foothills of the Front Range at sunrise (copyright photograph by Lynn Bashaw, used with permission). 


\section{Quality of Groundwater in the Denver Basin Aquifer System, Colorado, 2003-5}

By Marylynn Musgrove, Jennifer A. Beck, Suzanne S. Paschke, Nancy J. Bauch, and Shana L. Mashburn

National Water-Quality Assessment Program

Scientific Investigations Report 2014-5051 


\section{U.S. Department of the Interior \\ SALLY JEWELL, Secretary}

\section{U.S. Geological Survey \\ Suzette M. Kimball, Acting Director}

\section{U.S. Geological Survey, Reston, Virginia: 2014}

For more information on the USGS — the Federal source for science about the Earth, its natural and living resources, natural hazards, and the environment, visit http://www.usgs.gov or call 1-888-ASK-USGS.

For an overview of USGS information products, including maps, imagery, and publications, visit http://www.usgs.gov/pubprod

To order this and other USGS information products, visit http://store.usgs.gov

Any use of trade, firm, or product names is for descriptive purposes only and does not imply endorsement by the U.S. Government.

Although this information product, for the most part, is in the public domain, it also may contain copyrighted materials as noted in the text. Permission to reproduce copyrighted items must be secured from the copyright owner.

Suggested citation:

Musgrove, M., Beck, J.A., Paschke, S.S., Bauch, N.J., and Mashburn, S.L., 2014, Quality of groundwater in the Denver Basin aquifer system, Colorado, 2003-5: U.S. Geological Survey Scientific Investigations Report 2014-5051, 107 p., http://dx.doi.org/10.3133/sir20145051.

ISSN 2328-031X (print)

ISSN 2328-0328 (online)
ISBN 978-1-4113-3785-5 


\section{Acknowledgments}

The authors thank the landowners, municipalities, and local agencies that provided access to property for the installation and sampling of monitoring wells or the sampling of domestic and public-supply wells. The sampling and analysis of groundwater age constituents were done in cooperation with Denver Water and Colorado Springs Utilities. 



\section{Contents}

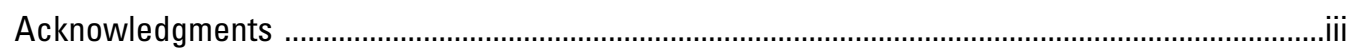

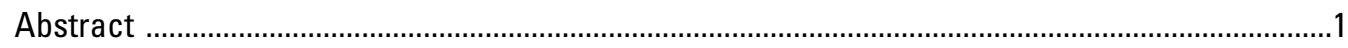

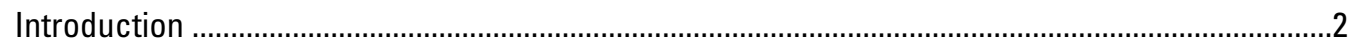

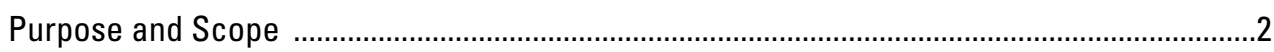

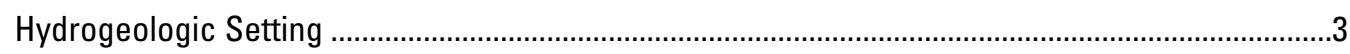

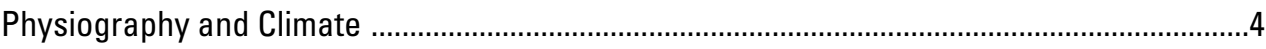

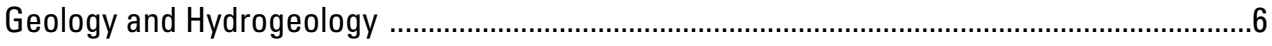

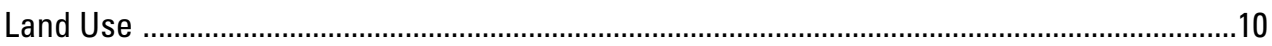

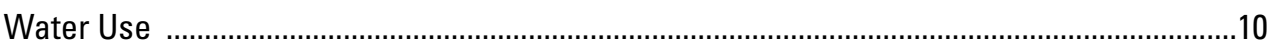

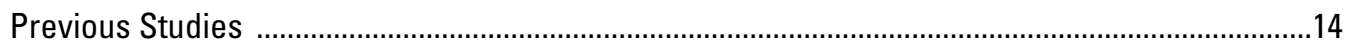

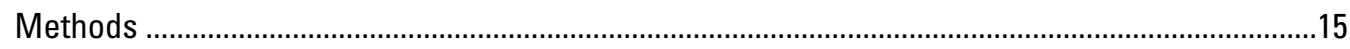

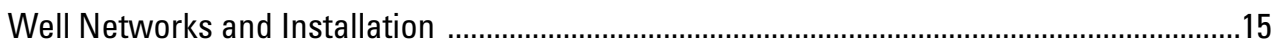

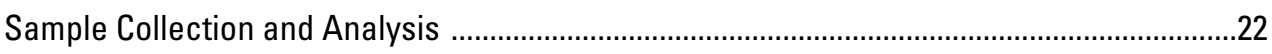

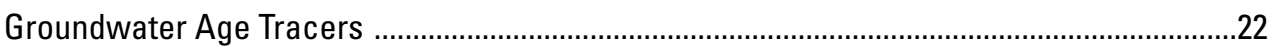

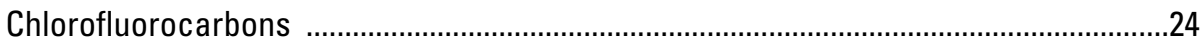

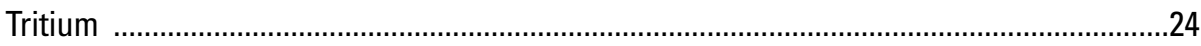

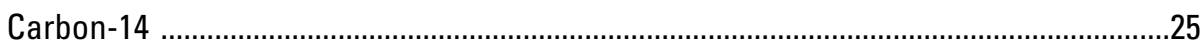

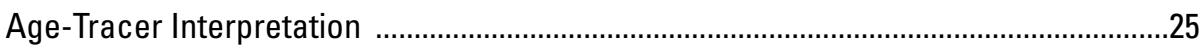

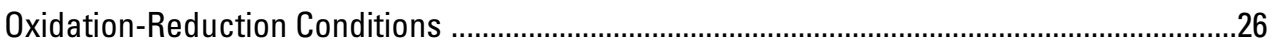

Water-Quality Data Presentation and Statistical Methods ..................................................26

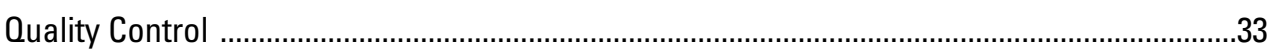

Quality of Groundwater in the Denver Basin Aquifer System ......................................................37

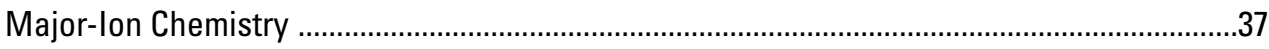

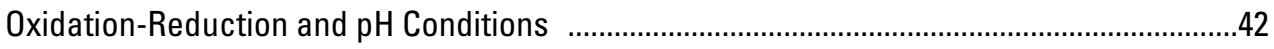

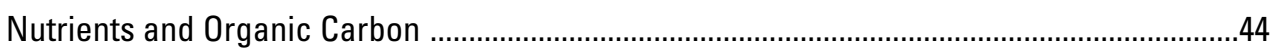

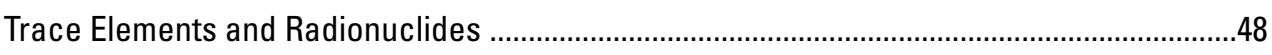

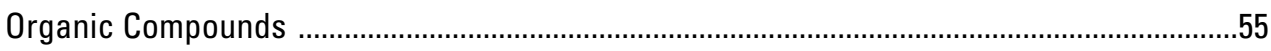

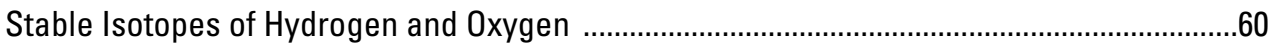

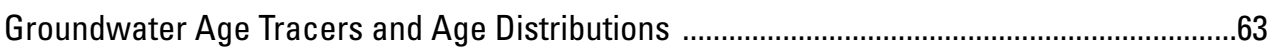

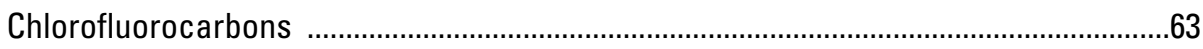

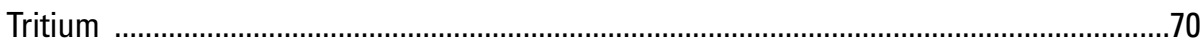

Carbon-14 and Adjustment of Radiocarbon Ages ......................................................71

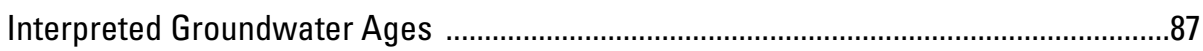

Synthesis: Vulnerability of the Denver Basin Aquifer System to Contamination ............................90

Denver Basin Groundwater Quality in a National Context ........................................................94

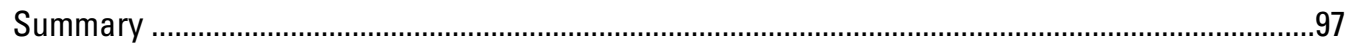

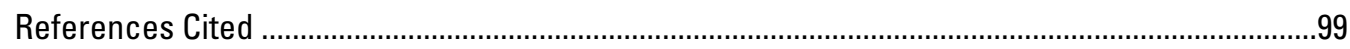




\section{Figures}

1. Map showing regional setting of the Denver Basin aquifer system, Colorado .3

2. Map showing regional setting of the South Platte River Basin and the Denver Basin aquifer system, Colorado

3. Map showing location and hydrogeologic setting of the Denver Basin aquifer system, Colorado .5

4. Conceptual block diagram illustrating hydrogeologic features of the Denver Basin aquifer system, Colorado .6

5. Map showing geology and extent of alluvial and bedrock aquifers, Denver Basin aquifer system, Colorado

6. Map showing land use in the Denver Basin, Colorado, 2001 11

7. Graph showing total estimated pumping from Denver Basin alluvial-aquifer and bedrock-aquifer wells, Denver Basin aquifer system, Colorado, 1880-2003

8. Graphs showing percentages of wells and estimated pumping from the Denver Basin aquifer system, Colorado, 2003

9. Map showing hydrogeologic setting and locations of groundwater wells sampled for water quality, Denver Basin aquifer system, Colorado, 2003-5 .

10. Trilinear diagram showing relations between major cations and anions in groundwater samples, Denver Basin aquifer system, Colorado, 2003-5

11. Graphs showing distribution of total dissolved solids concentrations for groundwater samples, Denver Basin aquifer system, Colorado, 2003-5

12. Graph showing distribution of bicarbonate concentration by bedrock aquifer for groundwater samples, Denver Basin aquifer system, Colorado, 2003-5

13. Map showing hydrogeologic setting and location of sampled wells distinguished by total dissolved solids concentrations, Denver Basin aquifer system, Colorado, 2003-5

14. Graph showing distribution of the molar ratio of sodium to calcium plus magnesium (sodium excess) by bedrock aquifer for groundwater samples, Denver Basin aquifer system, Colorado, 2003-5

15. Graphs showing oxidation-reduction classification for groundwater samples, Denver Basin aquifer system, Colorado, 2003-5

16. Graph showing distribution of dissolved oxygen and nitrate concentrations for groundwater samples, Denver Basin aquifer system, Colorado, 2003-5

17. Graphs showing dissolved-constituent relations for groundwater samples, Denver Basin aquifer system, Colorado, 2003-5

18. Graph showing distribution of $\mathrm{pH}$ values for groundwater samples from the bedrock aquifers, Denver Basin aquifer system, Colorado, 2003-5

19. Graph showing relation between well depth and nitrate concentration for groundwater samples, Denver Basin aquifer system, Colorado, 2003-5

20. Graphs showing relation between well depth and concentration for selected trace elements for groundwater samples, Denver Basin aquifer system, Colorado, 2003-5

21. Graph showing exceedances of water-quality benchmarks for selected trace elements and radionuclides for groundwater samples, Denver Basin aquifer system, Colorado, 2003-5

22. Graphs showing relation between selenium and selected geochemical constituent concentrations for groundwater samples, Denver Basin aquifer system, Colorado, 2003-5 
23. Graphs showing relation between uranium and bicarbonate concentrations for groundwater samples, Denver Basin aquifer system, Colorado, 2003-5 . .53

24. Graph showing distribution of radon concentration for groundwater samples, Denver Basin aquifer system, Colorado, 2003-5

25. Graphs showing distribution of iron and manganese concentrations for anoxic and oxic conditions for groundwater samples, Denver Basin, Colorado, 2003-5

26. Graphs showing relation between well depth and the number of organic compounds detected for groundwater samples, Denver Basin aquifer system, Colorado, 2003-5

27. Graphs showing frequency of detection of organic compounds for groundwater samples, Denver Basin aquifer system, Colorado, 2003-5

28. Graphs showing relation between deuterium and oxygen isotopes for groundwater samples, Denver Basin aquifer system, Colorado, 2003-5

29. Graph showing relation between deuterium isotopes and adjusted carbon-14 ages for bedrock-aquifer samples, Denver Basin aquifer system, Colorado, 2003-5

30. Map showing hydrogeologic setting and locations of bedrock-aquifer wells distinguished by enriched delta-deuterium values, Denver Basin aquifer system, Colorado, 2003-5

31. Graph showing relation between well depth and chlorofluorocarbon concentration (chlorofluorocarbon-12) for groundwater samples, Denver Basin aquifer system, Colorado, 2003-5

32. Graph showing relation between well depth and tritium concentration for groundwater samples, Denver Basin aquifer system, Colorado, 2003-5

33. Photographs showing occurrence of gypsum in Denver Formation sediments, Adams County, Colorado

34. Graph showing relation between well depth and adjusted carbon-14 ages for groundwater samples, Denver Basin aquifer system, Colorado, 2003-5

35. Graph showing relation between well depth and groundwater age interpretation category for groundwater samples, Denver Basin aquifer system, Colorado, 2003-5

36. Graph showing relation between well depth and the estimated proportion of young water from groundwater age interpretation, Denver Basin aquifer system, Colorado, 2003-5

37. Graphs showing summary of occurrence and detection of water-quality constituents used to evaluate vulnerability to contamination for groundwater samples, Denver Basin aquifer system, Colorado, 2003-5

38. Maps showing hydrogeologic setting and location of sampled wells with detections of selected water-quality constituents, Denver Basin aquifer system, Colorado, 2003-5.

39. Graph showing relation between well depth and groundwater age interpretation category for groundwater samples, distinguished by dissolved oxygen concentration and detections of volatile organic compounds, Denver Basin aquifer system, Colorado, 2003-5

40. Graphs showing comparison of selected water-quality results from the National Water-Quality Assessment Program, 1991-2010, with samples from the Denver Basin aquifer system, Colorado, 2003-5 


\section{Tables}

1. Stratigraphic, hydrogeologic, and lithologic characteristics of the Denver Basin aquifers, Colorado

2. Summary of water-quality studies and data collected for National Water-Quality Assessment Program studies, Denver Basin aquifer system, Colorado, 2003-5

3. Site information for wells sampled in the Denver Basin aquifer system, Colorado, 2003-5

4. Analytes measured, sample treatment and preservation, and analytical methods for samples collected from the Denver Basin aquifer system, Colorado, 2003-5

5. Summary statistics for well completion information, physicochemical properties, and selected geochemical constituents for groundwater samples from the Denver Basin aquifer system, Colorado, 2003-5

6. Constituents detected in groundwater field-blank samples, Denver Basin aquifer system, Colorado, 2003-5

7. Summary of replicate sample results for quality-control samples, Denver Basin aquifer system, Colorado, 2003-5

8. Summary of field-spike results for quality-control samples, Denver Basin aquifer system, Colorado, 2003-5

9. Summary statistics for groundwater samples with detections of selected pesticide compounds and volatile organic compounds, Denver Basin aquifer system, Colorado, 2003-5

10. Summary of chlorofluorocarbon and tritium age-tracer and associated data for groundwater samples, Denver Basin aquifer system, Colorado, 2003-5

11. Summary of carbon-14 age-tracer data and modeled age adjustments for groundwater samples, Denver Basin aquifer system, Colorado, 2003-5

12. Model constraints, model phases, and isotopic data used in Netpath models for groundwater samples, Denver Basin aquifer system, Colorado, 2003-5

13. Summary of age tracers, age interpretation, and associated data for groundwater samples, Denver Basin aquifer system, Colorado, 2003-5 


\section{Conversion Factors and Datums}

Inch/Pound to SI

\begin{tabular}{lcl}
\hline \multicolumn{1}{c}{ Multiply } & By & \multicolumn{1}{c}{ To obtain } \\
\hline inch (in.) & Length & \\
inch (in.) & 2.54 & centimeter $(\mathrm{cm})$ \\
foot (ft) & 25.4 & millimeter $(\mathrm{mm})$ \\
\hline & 0.3048 & meter $(\mathrm{m})$ \\
\hline square mile $\left(\mathrm{mi}^{2}\right)$ & Area & square kilometer $\left(\mathrm{km}^{2}\right)$ \\
\hline & 2.590 & liter $(\mathrm{L})$ \\
\hline ounce, fluid (fl. oz) & Volume & liter $(\mathrm{L})$ \\
pint (pt) & 0.02957 & liter $(\mathrm{L})$ \\
quart (qt) & 0.4732 & liter $(\mathrm{L})$ \\
gallon $($ gal) & 0.9464 & liter $(\mathrm{L})$ \\
cubic inch (in $\left.{ }^{3}\right)$ & 3.785 & \\
\hline & 0.01639 & cubic meter per second $\left(\mathrm{m}^{3} / \mathrm{s}\right)$ \\
\hline cubic foot per second (ft $3 / \mathrm{s})$ & Flow rate & gram $(\mathrm{g})$ \\
\hline & 0.02832 & becquerel per liter $(\mathrm{Bq} / \mathrm{L})$ \\
\hline ounce, avoirdupois $(\mathrm{oz})$ & Mass & \\
\hline picocurie per liter $(\mathrm{pCi} / \mathrm{L})$ & 28.35 & Radioactivity \\
\hline
\end{tabular}

SI to Inch/Pound

\begin{tabular}{lll}
\hline \multicolumn{1}{c}{ Multiply } & By & \multicolumn{1}{c}{ To obtain } \\
\hline centimeter (cm) & Length & \\
meter (m) & 0.3937 & inch (in.) \\
& 3.281 & foot (ft) \\
\hline cubic centimeter $\left(\mathrm{cm}^{3}\right)$ & Volume & cubic inch (in $\left.{ }^{3}\right)$ \\
liter (L) & 0.06102 & ounce, fluid (fl. oz) \\
liter (L) & 33.82 & pint (pt) \\
liter (L) & 2.113 & quart (qt) \\
liter (L) & 1.057 & gallon (gal) \\
\hline
\end{tabular}

Temperature in degrees Celsius $\left({ }^{\circ} \mathrm{C}\right)$ may be converted to degrees Fahrenheit $\left({ }^{\circ} \mathrm{F}\right)$ as follows:

${ }^{\circ} \mathrm{F}=\left(1.8 x^{\circ} \mathrm{C}\right)+32$

Temperature in degrees Fahrenheit $\left({ }^{\circ} \mathrm{F}\right)$ may be converted to degrees Celsius $\left({ }^{\circ} \mathrm{C}\right)$ as follows:

${ }^{\circ} \mathrm{C}=\left({ }^{\circ} \mathrm{F}-32\right) / 1.8$

Vertical coordinate information is referenced to the National Geodetic Vertical Datum of 1929

(NGVD 29). 
Horizontal coordinate information is referenced to the Universal Transverse Mercator (UTM), Zone 13, North American Datum of 1983 (NAD 83).

Land-surface altitude, as used in this report, refers to distance above the vertical datum.

Chlorofluorocarbon (CFC) concentrations are given in units of picograms per kilogram (pg/ $\mathrm{kg}$ ) and picomoles per kilogram (pmol/kg). One picogram is $10^{-12}$ grams. One picomole is $10^{-12}$ moles. One mole contains $6.022 \times 10^{23}$ atoms or molecules of a substance. CFC concentrations in gases are expressed as a mixing ratio; that is, volume of gas per volume of dry air, in parts per trillion (parts per trillion by volume [pptv]). The mixing ratio is calculated as the atmospheric concentration that would yield the measured aqueous concentration assuming equilibrium partitioning between atmosphere and water under the specified conditions (recharge temperature, recharge altitude, and excess-air concentration).

Tritium concentrations are given in units of tritium units (TU). Based upon a tritium half-life of 12.32 years (Lucas and Unterweger, 2000), 1 TU is equal to 3.22 picocuries per liter.

\section{Explanation of Isotope Units}

Per mil: A unit expressing the ratio of stable isotope abundances of an element in a sample to those of a standard material. Per mil units are equivalent to parts per thousand. Stable isotope ratios are computed as follows (Coplen and others, 2002):

$$
\delta \mathrm{X}=\left(\mathrm{R}_{\text {sample }} / \mathrm{R}_{\text {standard }}-1\right) \times 1,000
$$

where

$\delta \quad$ is the "delta" notation,

$\mathrm{X}$ is the heavier stable isotope, and

$\mathrm{R}$ is the ratio of the heavier, less abundant isotope to the lighter, stable isotope in a sample or standard.

The $\delta$ values for stable isotope ratios discussed in this report are referenced to the following standard materials:

\begin{tabular}{lll}
\hline \multicolumn{1}{c}{ Element } & \multicolumn{1}{c}{$\mathbf{R}$} & \multicolumn{1}{c}{ Standard identity and reference } \\
\hline Carbon & Carbon-13/carbon-12 & Vienna PeeDee Belemnite (Fritz and Fontes, 1980) \\
Hydrogen & Hydrogen-2/hydrogen-1 & Vienna Standard Mean Ocean Water (Fritz and Fontes, 1980) \\
Oxygen & Oxygen-18/oxygen-16 & Vienna Standard Mean Ocean Water (Fritz and Fontes, 1980) \\
\hline
\end{tabular}




\section{Abbreviations, Acronyms, and Symbols}

\begin{tabular}{|c|c|c|c|}
\hline As & arsenic & $\mathrm{mi}^{2}$ & square mile \\
\hline${ }^{13} \mathrm{C}$ & carbon-13 & MTBE & methyl tert-butyl ether \\
\hline${ }^{14} \mathrm{C}$ & carbon-14 & $\mathrm{N}$ & nitrogen \\
\hline $\mathrm{Ca}$ & calcium & $\mathrm{N}_{2}$ & nitrogen gas \\
\hline CFCs & chlorofluorocarbons & $\mathrm{Na}$ & sodium \\
\hline $\mathrm{CH}_{4}$ & methane & NAWQA & National Water-Quality Assessment \\
\hline chloroform & trichloromethane & $\mathrm{NH}_{3}$ & ammonia \\
\hline $\mathrm{Cl}$ & chloride & $\mathrm{NH}_{4}$ & ammonium \\
\hline $\mathrm{CO}_{2}$ & carbon dioxide & $\mathrm{NO}_{2}$ & nitrite \\
\hline$\delta \mathrm{D}$ & delta deuterium & $\mathrm{NO}_{3}$ & nitrate \\
\hline$\delta^{18} \mathrm{O}$ & delta oxygen-18 & NWIS & National Water Information System \\
\hline$\delta^{13} \mathrm{C}$ & delta carbon-13 & NWQL & National Water Quality Laboratory \\
\hline DIC & dissolved inorganic carbon & $\mathrm{O}_{2}$ & oxygen \\
\hline DO & dissolved oxygen & PCE & tetrachloroethene \\
\hline DOC & dissolved organic carbon & $\mathrm{pCi} / \mathrm{L}$ & picocuries per liter \\
\hline \multirow[t]{2}{*}{ EPA } & U.S. Environmental Protection & $\mathrm{pmC}$ & percent modern carbon \\
\hline & Agency & PVC & polyvinyl chloride \\
\hline $\mathrm{Fe}$ & iron & QC & quality control \\
\hline $\mathrm{ft}$ & feet & redox & oxidation and reduction \\
\hline $\mathrm{ft}^{3} / \mathrm{s}$ & cubic feet per second & $\mathrm{Rn}$ & radon \\
\hline${ }^{3} \mathrm{H}$ & tritium & RPD & relative percent difference \\
\hline HBSL & health-based screening level & $\mathrm{Se}$ & selenium \\
\hline $\mathrm{HCO}_{3}$ & bicarbonate & SI & saturation index \\
\hline LRL & laboratory reporting level & SMCL & secondary maximum contaminant \\
\hline LT-MDL & long-term method detection level & & level \\
\hline MCL & maximum contaminant level & $\mathrm{SO}_{4}$ & sulfate \\
\hline $\mathrm{Mg}$ & magnesium & TDS & total dissolved solids \\
\hline $\mathrm{Mgal} / \mathrm{d}$ & million gallons per day & TU & tritium units \\
\hline $\mathrm{Mn}$ & manganese & $\mathrm{U}$ & uranium \\
\hline MWL & meteoric water line & UCL & upper confidence limit \\
\hline$\mu \mathrm{g} / \mathrm{L}$ & micrograms per liter & USGS & U.S. Geological Survey \\
\hline $\mathrm{mg} / \mathrm{L}$ & milligrams per liter & VOCs & volatile organic compounds \\
\hline
\end{tabular}





\title{
Quality of Groundwater in the Denver Basin Aquifer System, Colorado, 2003-5
}

\author{
By MaryLynn Musgrove, Jennifer A. Beck, Suzanne S. Paschke, Nancy J. Bauch, and Shana L. Mashburn
}

\begin{abstract}
Groundwater resources from alluvial and bedrock aquifers of the Denver Basin are critical for municipal, domestic, and agricultural uses in Colorado along the eastern front of the Rocky Mountains. Rapid and widespread urban development, primarily along the western boundary of the Denver Basin, has approximately doubled the population since about 1970, and much of the population depends on groundwater for water supply. As part of the National WaterQuality Assessment Program, the U.S. Geological Survey conducted groundwater-quality studies during 2003-5 in the Denver Basin aquifer system to characterize water quality of shallow groundwater at the water table and of the bedrock aquifers, which are important drinking-water resources. For the Denver Basin, water-quality constituents of concern for human health or because they might otherwise limit use of water include total dissolved solids, fluoride, sulfate, nitrate, iron, manganese, selenium, radon, uranium, arsenic, pesticides, and volatile organic compounds. For the water-table studies, two monitoring-well networks were installed and sampled beneath agricultural (31 wells) and urban ( 29 wells) land uses at or just below the water table in either alluvial material or near-surface bedrock. For the bedrock-aquifer studies, domestic- and municipal-supply wells completed in the bedrock aquifers were sampled. The bedrock aquifers, stratigraphically from youngest (shallowest) to oldest (deepest), are the Dawson, Denver, Arapahoe, and Laramie-Fox Hills aquifers. The extensive dataset collected from wells completed in the bedrock aquifers (79 samples) provides the opportunity to evaluate factors and processes affecting water quality and to establish a baseline that can be used to characterize future changes in groundwater quality. Groundwater samples were analyzed for inorganic, organic, isotopic, and age-dating constituents and tracers. This report discusses spatial and statistical distributions of chemical constituents and evaluates natural and human-related processes that affect water quality. Findings are synthesized to assess the vulnerability of the Denver Basin aquifer system to groundwater contamination.

The chemistry of groundwater samples collected from the water-table wells was generally different from that of samples collected from the bedrock-aquifer wells. Samples
\end{abstract}

from the water-table wells tended to have higher concentrations of total dissolved solids and most major ions. Concentrations of several constituents with potential human-health concerns, including nitrate, selenium, uranium, and arsenic, decreased with depth and were highest in samples from the water-table wells. Exceedances of drinking-water standards and waterquality benchmarks were more frequently associated with shallow groundwater samples; concentrations of total dissolved solids and sulfate exceeded water-quality benchmarks for about half or more of samples from the water-table wells. The sediments and rocks of the Denver Basin are natural sources of the trace elements selenium, uranium, and arsenic, which affect their concentrations in groundwater. Detections of organic contaminants, which are typically indicative of human sources of contamination to groundwater, were more frequent in samples from the water-table wells. Pesticide compounds and volatile organic compounds were detected in 33 and 62 percent, respectively, of water-table well samples. Detected organic contaminant concentrations were much less than the associated drinking-water standards. Samples collected from the bedrock aquifers had lower concentrations of total dissolved solids than did samples collected from the water-table wells, although within the bedrock-aquifer samples, concentrations increased from the Dawson to Denver to Arapahoe to Laramie-Fox Hills aquifers. Concentrations of total dissolved solids and many constituents varied spatially and with depth in the bedrock aquifers, likely as a result of ion-exchange and oxidationreduction reactions, which are important processes affecting water quality. Major-ion chemistry generally evolved from a calcium-bicarbonate to calcium-sulfate composition, with some sodium-bicarbonate and sodium-sulfate facies in the deeper bedrock aquifers, likely resulting from longer residence times and more extensive water-rock interaction. Oxidation-reduction conditions generally evolved from oxic at the water table to anoxic with increasing depth in the bedrock aquifers. Most samples from the bedrock aquifers were anoxic. Exceedances of drinking-water standards and water-quality benchmarks for the bedrock aquifers occurred in 1 percent or less of samples for nitrate, selenium, or arsenic; there were no exceedances for uranium. Exceedances for total dissolved solids, sulfate, manganese, and iron were generally between about 10 and 20 percent for the bedrock-aquifer samples. Radon concentrations, which were only measured in samples collected 
from two of the bedrock aquifers, exceeded the lower proposed drinking-water standard for more than 90 percent of samples but exceeded the higher alternative standard for less than 5 percent of samples. Pesticide compounds and volatile organic compounds were detected in 3 and 22 percent, respectively, of bedrock-aquifer samples, all at concentrations that were that were much less than drinking-water standards.

Water-quality data were synthesized to evaluate factors that affect spatial and depth variability in water quality and to assess aquifer vulnerability to contaminants from geologic materials and those of human origin. The quality of shallow groundwater in the alluvial aquifer and shallow bedrock aquifer system has been adversely affected by development of agricultural and urban areas. Land use has altered the pattern and composition of recharge. Increased recharge from irrigation water has mobilized dissolved constituents and increased concentrations in the shallow groundwater. Concentrations of most constituents associated with poor or degraded water quality in shallow groundwater decreased with depth; many of these constituents are not geochemically conservative and are affected by geochemical reactions such as oxidation-reduction reactions. Groundwater age tracers provide additional insight into aquifer vulnerability and help determine if young groundwater of potentially poor quality has migrated to deeper parts of the bedrock aquifers used for drinking-water supply. Age-tracer results were used to group samples into categories of young, mixed, and old groundwater. Groundwater ages transitioned from mostly young in the water-table wells to mostly mixed in the shallowest bedrock aquifer, the Dawson aquifer, to mostly old in the deeper bedrock aquifers. Although the bedrock aquifers are mostly old groundwater of good water quality, several lines of evidence indicate that young, contaminant-bearing recharge has reached shallow to moderate depths in some areas of the bedrock aquifers. The Dawson aquifer is the most vulnerable of the bedrock aquifers to contamination, but results indicate that the older (deeper) bedrock aquifers are also vulnerable to groundwater contamination and that mixing with young recharge has occurred in some areas. Heavy pumping has caused water-level declines in the bedrock aquifers in some parts of the Denver Basin, which has the potential to enhance the transport of contaminants from overlying units. Results of this study are consistent with the existing conceptual understanding of aquifer processes and groundwater issues in the Denver Basin and add new insight into the vulnerability of the bedrock aquifers to groundwater contamination.

\section{Introduction}

The alluvial and bedrock aquifers of the Denver Basin (the Denver Basin aquifer system) provide critical water resources for municipal, domestic, and agricultural irrigation uses in Colorado along the eastern front of the Rocky Mountains. Alluvial and eolian deposits that overlie the bedrock aquifers form a productive unconfined alluvial aquifer (Bjorklund and Brown, 1957; Smith and others, 1964; Robson, $1989,1996)$. The bedrock aquifers are primarily composed of sandstone interbedded with claystone and shale and underlie about 7,000 square miles $\left(\mathrm{mi}^{2}\right)$ of the semiarid Great Plains along the Rocky Mountain Front Range (Fenneman, 1931; Robson, 1987; Paschke, 2011) (fig. 1). Groundwater quality in the Denver Basin alluvial and bedrock aquifers is affected by natural climatic, geologic, and hydrologic conditions, as well as by human activities and land use. Natural factors that can affect groundwater quality include sediment and bedrock composition, water-rock interaction, oxidationreduction (redox) conditions, and evaporative concentration of constituents. Human activities that can affect groundwater quality include modification of natural groundwater flow and recharge by groundwater pumping; application of water (irrigation) and chemicals, such as fertilizers, to the land surface in agricultural and urban areas; and point-source discharge of nutrients and chemicals.

Studies of the water quality of the Denver Basin aquifer system were conducted during $2003-5$ as part of the U.S. Geological Survey (USGS) National WaterQuality Assessment (NAWQA) Program's regional focus on important principal aquifers across the Nation (Lapham and others, 2005). Understanding the quality of groundwater in the Denver Basin is important for human and aquatic ecosystem health and management and protection of the available resource. The NAWQA Program was implemented to assess, in a nationally consistent manner, the status and trends of the Nation's surface-water and groundwater quality and to understand the natural and human factors that affect water quality (Gilliom and others, 1995). NAWQA Program studies were initiated in the Denver Basin (1) to characterize the quality of shallow groundwater underlying areas of agricultural (predominantly non-irrigated wheat) and urban land uses and (2) to characterize the quality of drinking-water resources of the four bedrock aquifers: the Dawson, Denver, Arapahoe, and Laramie-Fox Hills.

\section{Purpose and Scope}

The purpose of this report is to (1) describe water quality in the Denver Basin, (2) document the occurrence and distribution of selected chemical constituents, (3) evaluate factors controlling spatial and depth variations in groundwater quality in the bedrock aquifers that supply drinking water, and (4) synthesize the findings to assess the vulnerability of the Denver Basin aquifer system to groundwater contamination from geologic materials and from human activities. NAWQA Program studies in the Denver Basin from 2003 to 2005 collected water-quality data from wells completed in the shallow (less than $[<] 115$ feet $[\mathrm{ft}]$ ) alluvial aquifer to the deepest bedrock aquifer (more than 2,000 ft below land surface). The extensive dataset collected from the four bedrock aquifers (chemical constituents measured in 79 samples) is 


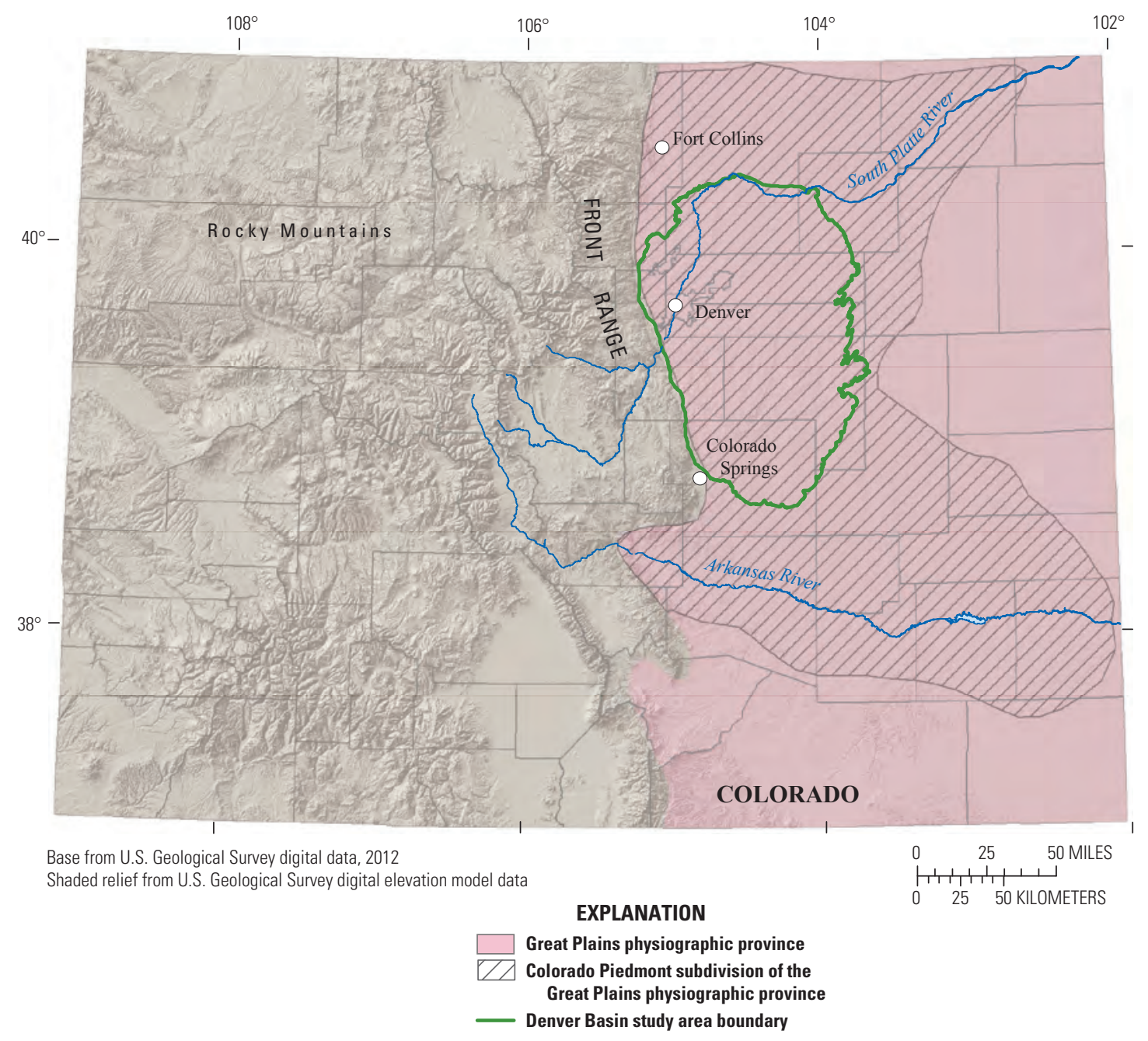

Figure 1. Regional setting of the Denver Basin aquifer system, Colorado.

used to evaluate physical and chemical processes that affect groundwater quality and to establish a baseline against which future water-quality data can be compared. Spatial and statistical distributions of chemical constituents are discussed, along with an evaluation of natural and humanrelated processes that affect water quality. For the Denver Basin, water-quality constituents of concern for human health or because they might otherwise limit use of water include total dissolved solids (TDS), fluoride (F), sulfate $\left(\mathrm{SO}_{4}\right)$, nitrate $\left(\mathrm{NO}_{3}\right)$, iron $(\mathrm{Fe})$, manganese $(\mathrm{Mn})$, selenium $(\mathrm{Se})$, radon $(\mathrm{Rn})$, uranium (U), arsenic (As), pesticides, and volatile organic compounds (VOCs). Results of this report can be used by water managers, stakeholders, and users at the local, regional, and State level to better understand the general distribution of groundwater quality in the Denver Basin and factors that affect that distribution and to evaluate the vulnerability of the deeper bedrock aquifers to contaminants derived from geologic and human sources under current water-use conditions.

\section{Hydrogeologic Setting}

The Front Range urban corridor of Colorado is composed of the urban and suburban areas extending from Colorado Springs in the south to Fort Collins in the north and includes the greater metropolitan area of Denver (Robson, 1989) (fig. 1). Population of the metropolitan areas overlying the Denver Basin aquifer system has approximately doubled from about 1.3 million in 1970 to about 2.7 million in 2005, an increase that has been accompanied by an increase in groundwater use for water supply (Paschke, 2011). Extensive urban development on the west side of the Denver Basin has occurred between the cities of Denver and Colorado 
Springs. Much of this urban population uses groundwater pumped from the Denver Basin for municipal water supply, and domestic (self-supplied) groundwater use is widespread across the rural parts of the basin (Paschke, 2011). The South Platte River Basin (fig. 2) is an important agricultural area, and groundwater from the South Platte River alluvial aquifer is used to support agricultural irrigation and domestic water supply (Paschke, 2011).

\section{Physiography and Climate}

Situated in the Colorado Piedmont subdivision of the Great Plains physiographic province (fig. 1), the Denver Basin's topography is characterized by rolling hills and dissected plains (Trimble, 1980). The topographic high point of about $8,000 \mathrm{ft}$ above the National Geodetic Vertical Datum of 1929 (NGVD 29) is in the southern third of the Denver Basin along the Palmer Divide (Trimble, 1980) (fig. 3).
The Palmer Divide (fig. 3) is the drainage divide between the tributaries of the South Platte River to the north and those of the Arkansas River to the south (fig. 1). Surface drainage generally is north toward the South Platte River in the northern two-thirds of the basin, whereas surface drainage in the southern one-third of the basin is south toward the Arkansas River. The topographic low point of about 4,300 ft above NGVD 29 is near the South Platte River in the northeast part of the basin (Paschke, 2011). Native vegetation over much of the Denver Basin consists of grasslands with mixed-grass prairie and low shrubs (Keith and Maberry, 1973). Along the foothills, the land surface is covered with open stands of mountain mahogany, Gambel shrub oak, and other rangeland shrubs (Keith and Maberry, 1973). Phreatophytes such as cottonwood trees and willows grow in lowlands and flood plains in the Denver Basin and along the South Platte River (Keith and Maberry, 1973; Driscoll, 1974, 1975).

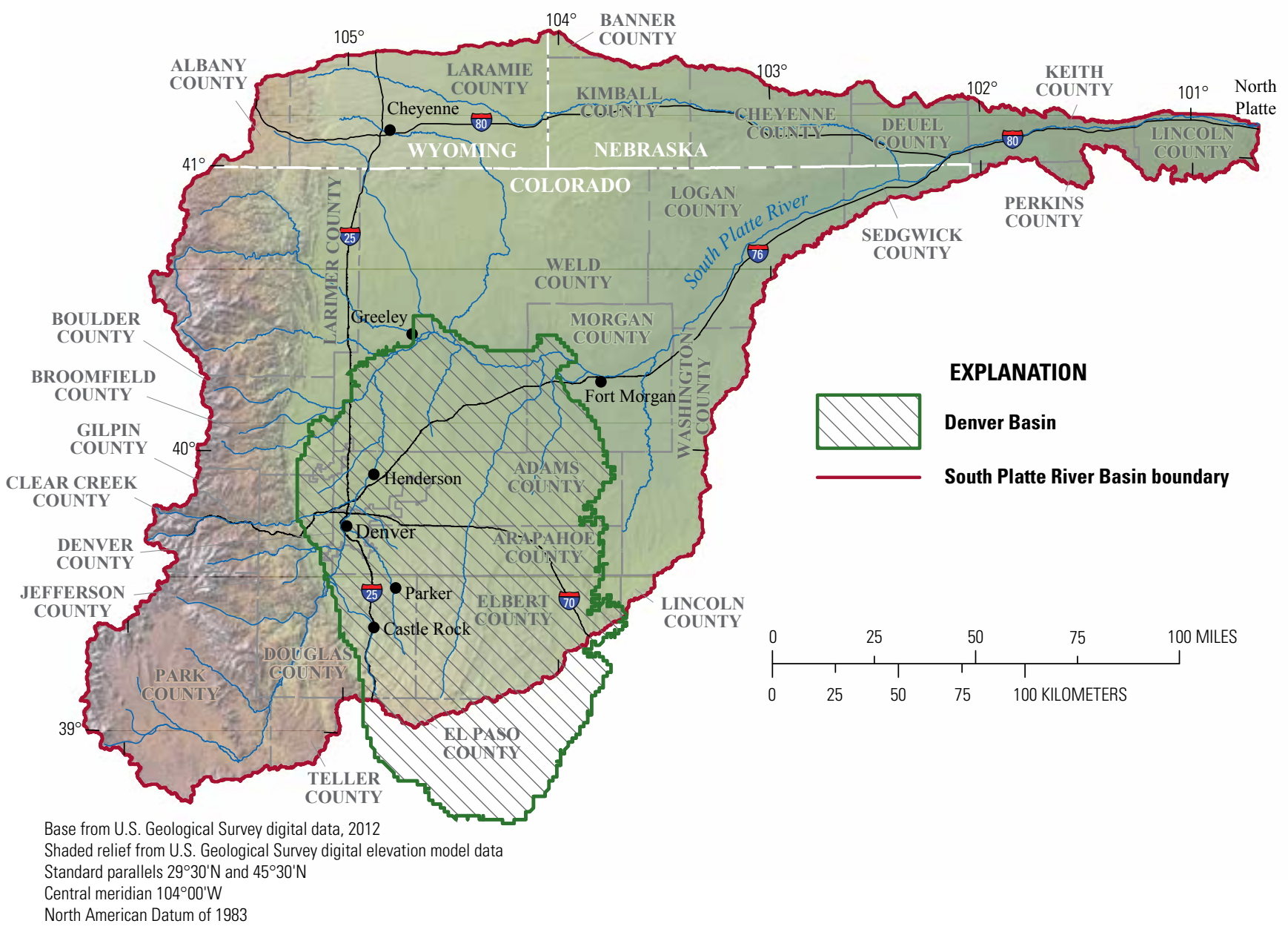

Figure 2. Regional setting of the South Platte River Basin and the Denver Basin aquifer system, Colorado. 


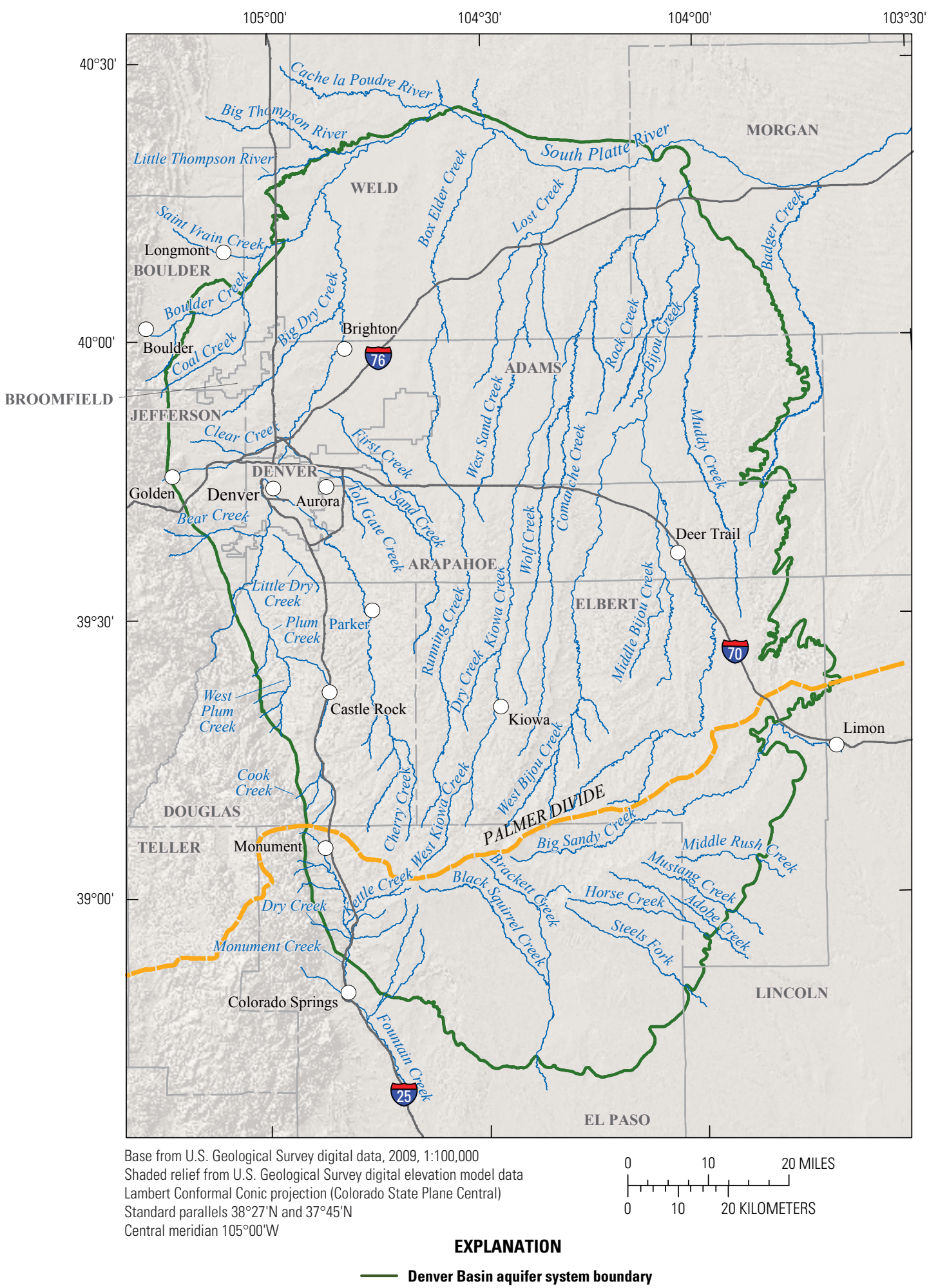

Figure 3. Location and hydrogeologic setting of the Denver Basin aquifer system, Colorado. 
The regional climate is characterized as semiarid (Hansen and others, 1978) with basinwide long-term average precipitation of about 15 inches ( 38 centimeters) per year (1930-2003) (Paschke, 2011). Most precipitation goes to evapotranspiration and surface-water runoff, with a small amount estimated to provide recharge to the bedrock aquifers (Moore and others, 2007; Paschke, 2011). Topography of the Rocky Mountain Front Range of Colorado affects the semiarid climate and weather over the plains in the Denver Basin east of the Rocky Mountain front (Robson, 1989; Paschke, 2011). The Rocky Mountain Front Range creates an orographic effect on weather patterns such that, as westerly winds from the Pacific Coast rise over the mountains, most of the precipitation falls in the form of rain and snow along the Continental Divide. This orographic effect causes a rain shadow on the eastern slope of the mountains and the Denver Basin, which contributes to the semiarid climate (Scott, 1963a; Robson, 1989). The Palmer Divide creates a local orographic effect on storms in the Denver Basin, resulting in greater precipitation rates at higher altitudes near the divide (Hansen and others, 1978; Paschke, 2011). Analysis of long-term (1931-2003) mean annual precipitation data from 129 weather stations in and near the Denver Basin (National Oceanic and Atmospheric Administration, 2004) indicates that the spatial distribution of precipitation ranges from about 11.5 inches per year at lower altitudes along the South Platte River to about 20 inches per year at the highest altitudes along the western basin margin and the Palmer Divide (Paschke, 2011). About 70 percent of precipitation falls during the 6-month period from April through September, with the remainder occurring during winter (Hansen and others, 1978).

\section{Geology and Hydrogeology}

The Denver Basin aquifer system consists of the uppermost layers of the larger structural Denver Basin (fig. 4), which is a double-plunging syncline with high-angle dips along the western basin margin and low-angle dips in the central and eastern parts of the basin (Anderman and Ackman, 1963; Nwangwu, 1977; Robson, 1987; Robson and others, 1998). The geology and hydrogeology of the Denver Basin aquifer system are described in detail by Paschke (2011) and summarized herein. Unconsolidated Quaternary alluvial and eolian deposits overlie the bedrock aquifers along presentday and prehistoric channels of the South Platte River and its tributaries and form a productive unconfined alluvial aquifer where saturated (Bjorklund and Brown, 1957; Smith

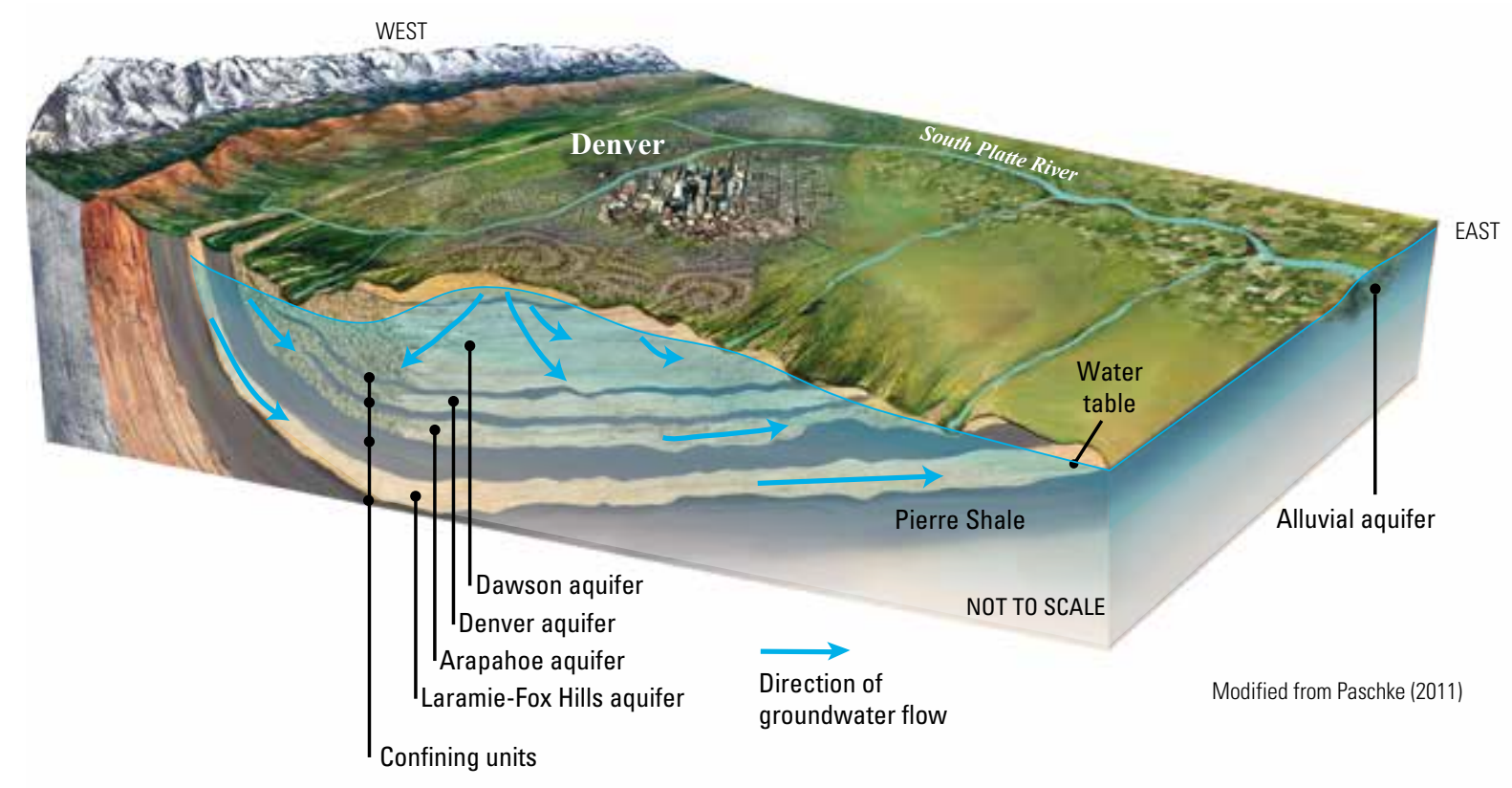

Figure 4. Conceptual block diagram illustrating hydrogeologic features of the Denver Basin aquifer system, Colorado. 
and others, 1964; Robson, 1989, 1996). About 30 percent of the total basin-area land surface consists of the alluvial aquifer (fig. 5). The bedrock aquifers are composed of Late Cretaceous- to Tertiary-age consolidated to semiconsolidated sandstones (Robson, 1987; Raynolds, 2002; Paschke, 2011) (table 1). From stratigraphically youngest (shallowest) to oldest (deepest), the hydrogeologic units that compose the Denver Basin bedrock aquifers are the (1) Dawson aquifer, (2) Denver aquifer, (3) Arapahoe aquifer, and (4) Laramie-Fox Hills aquifer (Romero, 1976; Robson, 1983, 1987) (fig. 4). The Dawson and Arapahoe aquifers are further divided into upper and lower aquifers in parts of the basin on the basis of the presence of intervening confining units (VanSlyke and others, 1988a, 1988b) such that six bedrock aquifers are recognized for administrative purposes (Colorado Division of Water Resources, 1998). For the current study the Dawson and Arapahoe aquifers are not subdivided but are considered as single aquifer units. The upper part of the Dawson aquifer is the uppermost bedrock unit of the basin, with only a small part of the Dawson aquifer overlain by the alluvial aquifer. As a result, most of the Dawson aquifer outcrops at the land surface. The Denver aquifer underlies much of the topographically flatter parts of the basin and has the greatest outcrop area of the bedrock aquifers (Paschke, 2011) (fig. 5). Depth to the base of the Laramie-Fox Hills aquifer is as much as 2,300 ft below land surface near the center of the basin (Paschke, 2011). A thick unit of low-permeability Cretaceousage Pierre Shale underlies the Laramie-Fox Hills aquifer and forms the base of the aquifer system (Nwangwu, 1977; Robson, 1983). Because of the bowl-shaped structure of the Denver Basin, bedrock aquifers outcrop in a ringlike pattern with the oldest unit (the Laramie-Fox Hills aquifer) around the basin margins and the youngest unit (Dawson aquifer) near the center of the basin (figs. 4 and 5). Throughout this report, the stratigraphic sequence of bedrock aquifers from the Dawson to Denver to Arapahoe to Laramie-Fox Hills aquifers is referred to as "from the shallowest to deepest bedrock aquifers"; this is a generalization based on the aquifers' stratigraphic relations from youngest to oldest, although the depth of each aquifer varies spatially with the deepest depths near the center of the basin. Aquifer materials are synorogenic sediment deposited east of the Rocky Mountain Front Range during the Laramide Orogeny and exhibit substantial horizontal and vertical heterogeneity (Scott, 1963b; Weimer, 1973; Epis and others, 1976; Robson, 1987; Weimer and LeRoy, 1987; Raynolds, 2002) (table 1). Interbedded claystone and shale confining units separate the bedrock sandstone aquifers (Scott, 1963b; Weimer, 1973; Romero, 1976) (fig. 4; table 1). The quality of groundwater in the basin is affected by the sediments and minerals that compose the aquifers, which are sources of natural contaminants such as $\mathrm{U}, \mathrm{Se}$, and $\mathrm{Rn}$ (table 1).
Confined groundwater conditions dominate in the bedrock aquifers where they are overlain by younger, less permeable units, and unconfined groundwater conditions exist in the alluvium and in areas where the bedrock aquifers lie near the land surface (Paschke, 2011). Recharge to the alluvial and bedrock aquifers occurs by infiltration of incident precipitation, streamflow, lawn-irrigation return flow in developed areas, irrigation return flow in agricultural areas, and downward interaquifer flow (Paschke, 2011). Precipitation recharge to the bedrock aquifers is low, estimated as 1-2 percent of annual precipitation, and precipitation recharge to the alluvial aquifer has been estimated as 7 percent of annual precipitation (Paschke, 2011). Discharge from bedrock aquifers occurs as evapotranspiration and as flow to wells, streams, the alluvial aquifer, and springs (Paschke, 2011). Groundwater discharge to surface water can affect water supply, water quality, and the health of aquatic ecosystems (Winter and others, 1998).

Regional groundwater flow in the bedrock and alluvial aquifers is generally away from the topographic high and recharge area of the Palmer Divide toward discharge areas along the South Platte River to the north and toward the discharge areas of Monument Creek, Black Squirrel Creek, and Big Sandy Creek to the south (Robson, 1987; Paschke, 2011) (figs. 3 and 4). Downward hydraulic gradients also result in the downward movement of groundwater between aquifers, particularly from the Dawson and Denver aquifers into the Arapahoe aquifer; the Laramie-Fox Hills aquifer is an exception to this process because of its effective separation from overlying units by the Laramie confining unit (Robson, 1987; Paschke, 2011) (fig. 4; table 1). Although the rate of downward flow is small in comparison with lateral flow in the bedrock aquifers, downward flow occurs over a large area and likely results in large volumes of water moving between aquifers (Robson, 1987; Paschke, 2011).

Surface drainage in the basin is generally away from the Palmer Divide to the north, east, and south; streams tend to be perennial in upstream reaches near the Palmer Divide, where groundwater discharge from alluvial and bedrock aquifers supports surface-water flow. Perennial stream reaches, however, lose water to the extensive and permeable alluvial aquifer as topographic gradients decrease downstream, resulting in ephemeral and intermittent stream reaches (Paschke, 2011). In some developed drainages (such as the lower South Platte River and Plum and Cherry Creeks) perennial flow is maintained by groundwater discharge, reservoir releases, wastewater treatment discharge, agricultural irrigation return flow, and urban return flow (Paschke, 2011). As a result, the quality of water discharging to basin streams from shallow groundwater can affect the overall stream water chemistry. 


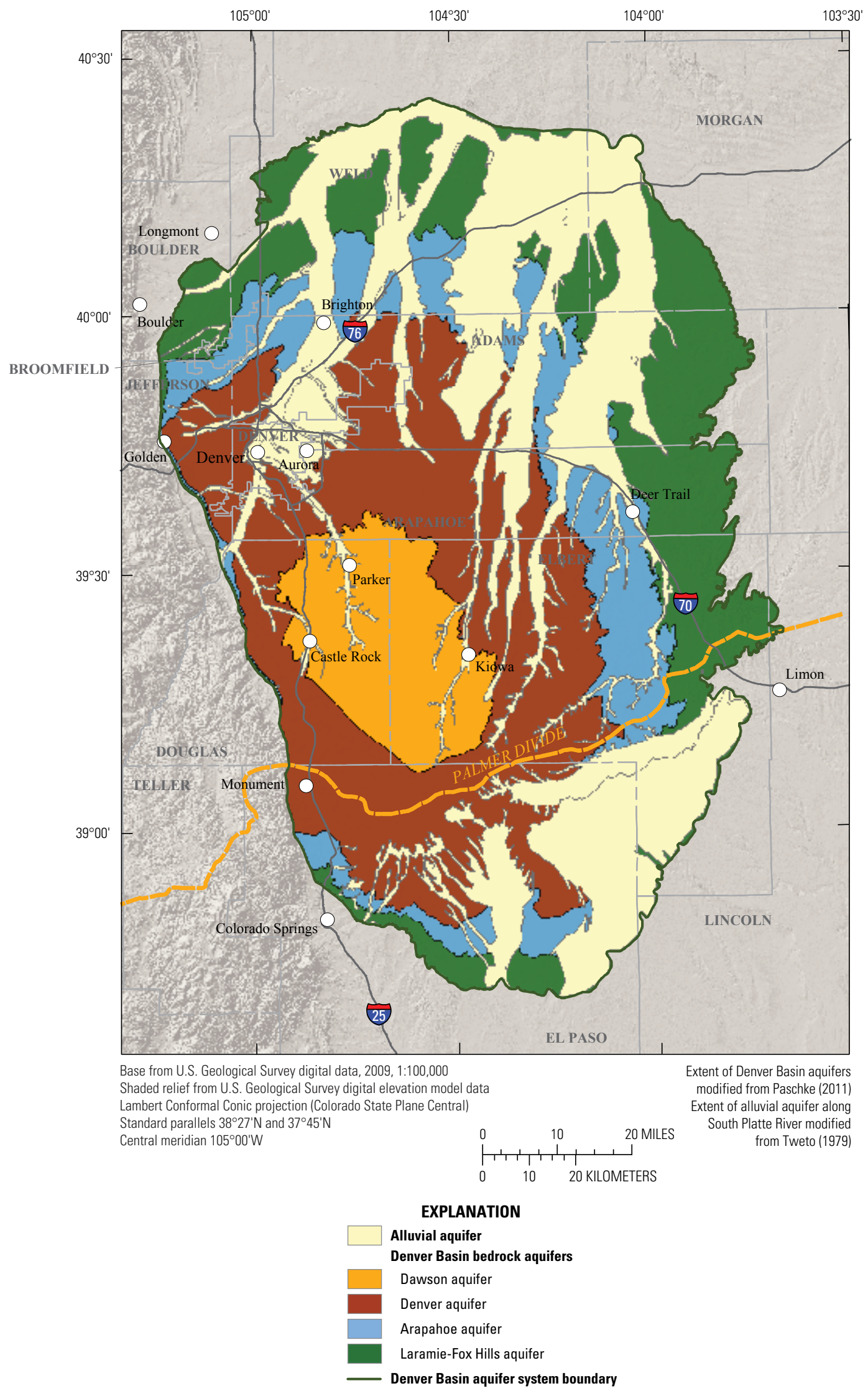

Figure 5. Geology and extent of alluvial and bedrock aquifers, Denver Basin aquifer system, Colorado. 
Table 1. Stratigraphic, hydrogeologic, and lithologic characteristics of the Denver Basin aquifers, Colorado (adapted from Paschke, 2011, and Robson and others, 1998).

[ft, feet; $\mathrm{U}$, uranium; Rn, radon; Se, selenium; Fe, iron]

\begin{tabular}{|c|c|c|c|c|c|c|c|}
\hline Age & $\begin{array}{l}\text { Stratigraphic } \\
\text { unit }\end{array}$ & $\begin{array}{c}\text { Hydrogeologic } \\
\text { unit }\end{array}$ & $\begin{array}{l}\text { Hydrogeologic } \\
\text { description }\end{array}$ & Lithologic description & $\begin{array}{l}\text { Median } \\
\text { hydraulic } \\
\text { conductivity } \\
\text { (ft per day) }\end{array}$ & $\begin{array}{l}\text { Range of } \\
\text { thickness } \\
\text { (ft) }\end{array}$ & Additional information \\
\hline Quaternary & $\begin{array}{l}\text { Alluvial, flood } \\
\text { plain, terrace, } \\
\text { colluvial, and } \\
\text { eolian sand, } \\
\text { gravel, and } \\
\text { clay deposits }\end{array}$ & $\begin{array}{l}\text { Alluvial } \\
\text { aquifer }\end{array}$ & $\begin{array}{l}\text { Productive } \\
\text { unconfined } \\
\text { alluvial } \\
\text { aquifer } \\
\text { where } \\
\text { saturated }\end{array}$ & $\begin{array}{l}\text { Unconsolidated sand and gravel with clay } \\
\text { lenses; primarily along present-day stream } \\
\text { channels; igneous and sedimentary rock } \\
\text { fragments. }\end{array}$ & 479 & $0-175$ & $\begin{array}{l}\text { No confining unit separates alluvial } \\
\text { aquifer and Dawson aquifer. }\end{array}$ \\
\hline $\begin{array}{l}\text { Tertiary } \\
\text { (Paleocene } \\
\text { to Eocene) }\end{array}$ & Dawson Arkose & $\begin{array}{l}\text { Dawson } \\
\text { aquifer }\end{array}$ & $\begin{array}{l}\text { Productive } \\
\text { unconfined } \\
\text { to confined } \\
\text { aquifer }\end{array}$ & $\begin{array}{l}\text { Channel sandstones, overbank mudstone/ } \\
\text { claystone deposits; upper sequence } \\
\text { of coarse-grained arkosic sandstones; } \\
\text { granitic sediments source of U and Rn to } \\
\text { groundwater. Upper and lower Dawson } \\
\text { aquifers separated by paleosol claystone } \\
\text { in northern part of Dawson extent. Lower } \\
\text { Dawson: mixed arkosic and andesitic } \\
\text { fluvial sandstone with interbedded } \\
\text { claystone, lignite, and volcanics. }\end{array}$ & 0.80 & $100-1,100$ & $\begin{array}{l}\text { Underlain by fine-grained confining } \\
\text { unit (1-150 ft thick) of upper } \\
\text { Denver Formation. }\end{array}$ \\
\hline $\begin{array}{l}\text { Late } \\
\text { Cretaceous }\end{array}$ & $\begin{array}{l}\text { Denver } \\
\text { Formation }\end{array}$ & Denver aquifer & $\begin{array}{l}\text { Confined to } \\
\text { unconfined } \\
\text { aquifer }\end{array}$ & $\begin{array}{l}\text { Alluvial fan, swamp, overbank deposits; } \\
\text { andesitic fluvial sandstone with volcanic } \\
\text { ash deposits, coal, lignite, mudstone/ } \\
\text { claystone; Fe-rich sediments; sediments } \\
\text { source of Se and U to groundwater. }\end{array}$ & 0.45 & $280-1,100$ & $\begin{array}{l}\text { Underlain by fine-grained } \\
\text { confining unit ( } 5-150 \mathrm{ft} \text { thick) } \\
\text { predominantly composed of } \\
\text { claystone with andesitic fluvial } \\
\text { sandstone. }\end{array}$ \\
\hline $\begin{array}{l}\text { Late } \\
\text { Cretaceous }\end{array}$ & $\begin{array}{l}\text { Arapahoe } \\
\text { Formation }\end{array}$ & $\begin{array}{l}\text { Arapahoe } \\
\text { aquifer }\end{array}$ & $\begin{array}{l}\text { Productive } \\
\text { confined } \\
\text { aquifer }\end{array}$ & $\begin{array}{l}\text { Fluvial environment, alluvial fan deposits } \\
\text { near mountain front; conglomerates, } \\
\text { sandstone, siltstone, shale; pebbles and } \\
\text { cobbles with granite, chert, metamorphic } \\
\text { rocks, and quartize; shale more prevalent } \\
\text { in northern part of basin. }\end{array}$ & 1.8 & $400-600$ & $\begin{array}{l}\text { Thick confining unit }(100-500 \mathrm{ft}) \\
\text { of gray to black shale, coal, } \\
\text { siltstone, and sandstone below } \\
\text { Arapahoe aquifer limits } \\
\text { downward movement of water } \\
\text { from Arapahoe to Laramie-Fox } \\
\text { Hills aquifer; wedge-shaped } \\
\text { confining unit thins to the east. }\end{array}$ \\
\hline $\begin{array}{l}\text { Late } \\
\text { Cretaceous }\end{array}$ & $\begin{array}{l}\text { Laramie } \\
\text { Formation } \\
\text { and Fox Hills } \\
\text { Sandstone }\end{array}$ & $\begin{array}{l}\text { Laramie-Fox } \\
\text { Hills aquifer }\end{array}$ & $\begin{array}{l}\text { Productive } \\
\text { confined to } \\
\text { unconfined } \\
\text { aquifer }\end{array}$ & $\begin{array}{l}\text { Laramie Formation: swamps, deltas, } \\
\text { overbank deposits; claystone, coal, fluvial } \\
\text { channel sandstone; contains coal and } \\
\text { lignite beds. Fox Hills Sandstone: marine } \\
\text { beach and delta-front environment; } \\
\text { sandstone, thin siltstone and claystone } \\
\text { beds; contains marine fossils. }\end{array}$ & 0.40 & $100-500$ & $\begin{array}{l}\text { A 5- to } 20 \text {-ft-thick shale bed } \\
\text { generally separates the Laramie } \\
\text { and Fox Hills; aquifer underlain } \\
\text { by Pierre Shale, a thick } \\
(5,200 \mathrm{ft}), \text { low permeability, } \\
\text { marine shale that forms base of } \\
\text { aquifer system. }\end{array}$ \\
\hline
\end{tabular}




\section{Land Use}

Land use in the Denver Basin has changed in response to development since the mid-1800s. Present-day (as of 2009) land use ranges from irrigated and non-irrigated agriculture along the South Platte River valley to high-density urban development in downtown Denver (Paschke, 2011) (fig. 6). Changes in the land cover over the Denver Basin include a reduction of native grasslands and shrubs and an increase in agricultural and urban areas and in suburban and rural residential housing (Paschke, 2011). National Land Cover Data for 2001 indicated that the Denver Basin area was 60 percent non-irrigated grassland and rangeland, 11 percent irrigated agricultural land, 16 percent non-irrigated agricultural land, 9 percent developed urban and suburban land, 3 percent forested land, and 1 percent open water or urban recreational areas (Homer and others, 2004; U.S. Geological Survey, 2001). Grassland and rangeland covers much of the central and southern basin, and irrigated and non-irrigated agricultural land is primarily in the northern basin along the South Platte River valley (Bruce and McMahon, 1998; Paschke, 2011) (fig. 6). Developed urban and suburban land is located along the western side of the Denver Basin and is associated with the metropolitan areas of Denver and Colorado Springs (fig. 6). Small towns, rural residences, and farms are spread across the less-populated part of the basin and use the Denver Basin aquifers for water supply. Pine forests occur at the highest altitudes in the basin along the Palmer Divide.

\section{Water Use}

Public water supply along the Front Range urban corridor uses a combination of surface water from the mountains of the Front Range and groundwater from alluvial and bedrock aquifers (Colorado Water Conservation Board, 2004). In rural areas, water is generally self-supplied from groundwater for domestic and irrigation purposes. The allocation of water in the State of Colorado gives seniority to older water rights for surface water and tributary groundwater; that is, groundwater that is hydraulically connected to surface water (Graham and VanSlyke, 2004). As a result, older municipalities such as Denver generally hold water rights senior to more recently established municipalities and suburbs, and public supply in established municipal areas of Denver and Colorado Springs is primarily from surface water. Much of the agricultural irrigation along the South Platte River and its tributaries is supplied by surface water delivered through irrigation diversion ditches by using water rights established in the mid1800s (Colorado Water Conservation Board, 2004). Tributary groundwater pumped from the alluvial aquifer is mainly used for agricultural irrigation because of its proximity to surface water and thus agricultural areas. The large hydraulic conductivity (table 1) and shallow depths to water of the alluvial aquifer facilitate its use as a readily available supply for agricultural irrigation (Hurr and others, 1975; Robson and Romero, 1981a, 1981b, 1981c).

Development of the bedrock aquifers began in the 1950s to support urban and suburban growth along the Front Range urban corridor (Paschke, 2011) (fig. 7). In contrast to water from the alluvial aquifer, which is used mostly for agricultural irrigation, water from the bedrock aquifers is used for municipal, commercial, industrial, and domestic supply (Robson, 1989; Paschke, 2011). Groundwater in the bedrock aquifers is administratively recognized as nonrenewable because the aquifers receive little precipitation recharge and are primarily confined (Graham and VanSlyke, 2004). In 1973, Senate Bill 73-113 recognized the existence of nontributary groundwater in the Denver Basin (that is, groundwater with little physical connection to surface water) and established rules for its administration with the goal of maintaining a 100-year aquifer life for a given parcel of land. By 1985, the continued increase in groundwater withdrawal from the Denver Basin prompted further study of the aquifers, and Senate Bill 85-5 clarified nontributary groundwater definitions and established the Denver Basin Rules. The bill adopted a 100 -year aquifer life to administer pumping rates, allowing for pumping at a rate of 1 percent per year, and accepted storage depletion by not protecting artesian head or aquifer water levels (Graham and VanSlyke, 2004). Denver Basin bedrock aquifer groundwater is considered mostly nontributary and is not subject to the prior-appropriation doctrine; it is allocated on the basis of ownership of overlying land and is subject to the 1 percent pumping per year rate. As a result, bedrock aquifer groundwater has been a readily available supply for population growth and for recently established municipalities in areas with little surface water, little tributary groundwater, or few available water rights (Moore and others, 2007). Additional information on groundwater law for the Denver Basin is available in Hobbs (2007).

Pumping from the bedrock aquifers has increased steadily over the last few decades (fig. 7) in response to increased population and municipal water-supply needs. For example, groundwater from the bedrock aquifers provides more than 70 percent of the water supply in the south Denver metropolitan area (fig. 6), and groundwater availability for long-term water demand is of concern (Colorado Water Conservation Board, 2004; Moore and others, 2007; Paschke, 2011). As described by Paschke (2011), three general areas of development rely heavily on Denver Basin groundwater for municipal supply: the south Denver metropolitan area, the northern area, and the Monument area (fig. 6). The Denver metropolitan area has experienced rapid population growth, with a 31 percent increase occurring between 1990 and 2000 and an additional 17 percent increase between 2000 and 2010 (U.S. Census Bureau, 2012). With increasing urban development in the basin, there is a growing demand on groundwater resources from the alluvial and bedrock aquifers (fig. 7). Although most wells are completed in the bedrock 


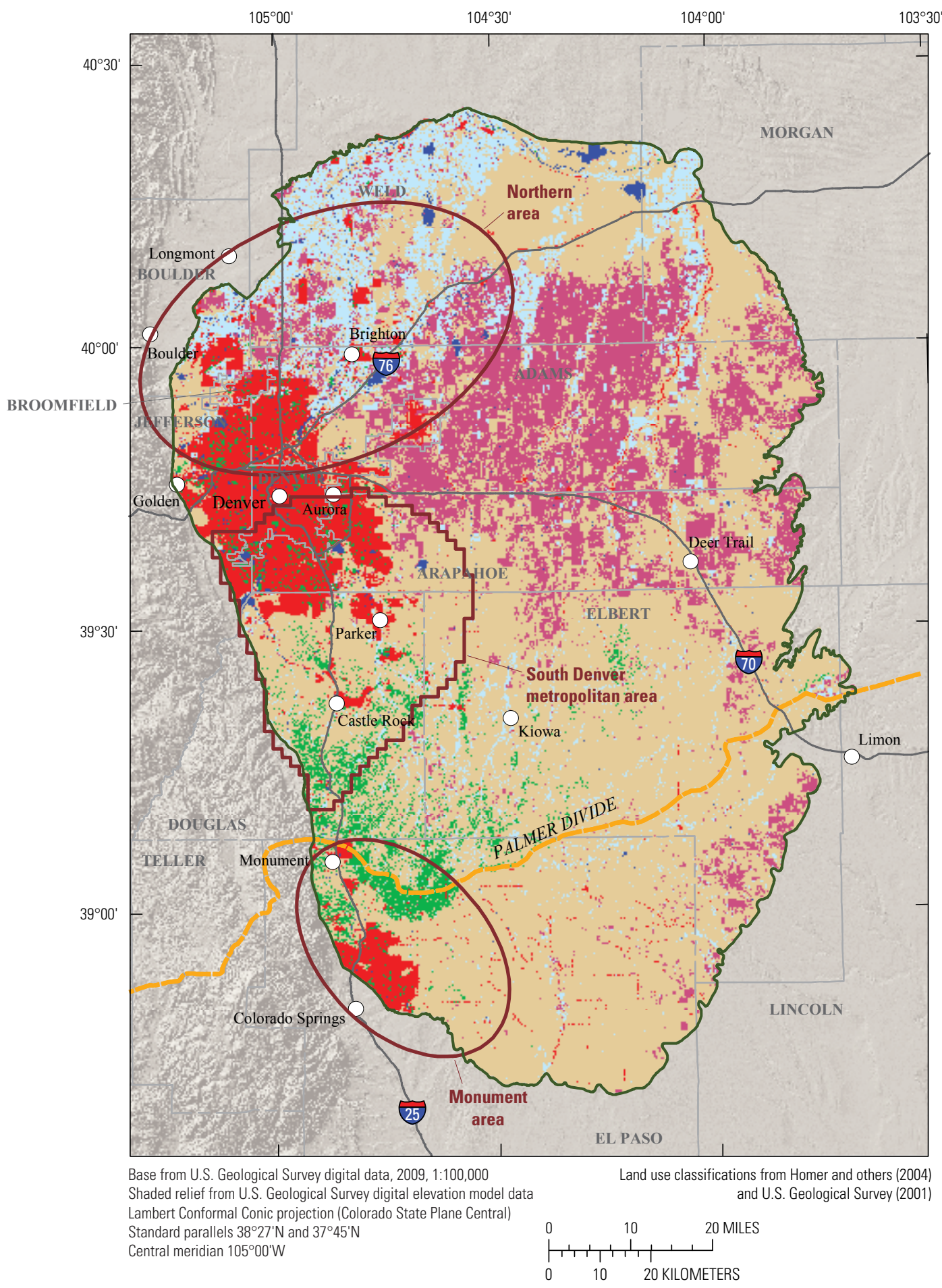

EXPLANATION

\begin{tabular}{|l|l|}
\hline Land use and land cover \\
Water \\
\hline Urban/suburban development \\
Forest \\
Grassland \\
Irrigated pasture or row crops \\
Non-irrigated small grains or fallow
\end{tabular}

Denver Basin aquifer system
boundary
Areas of recent urban/suburban
development with municipal
water supply dominantly
from bedrock aquifers
(from Paschke, 2011)

Figure 6. Land use in the Denver Basin, Colorado, 2001. 


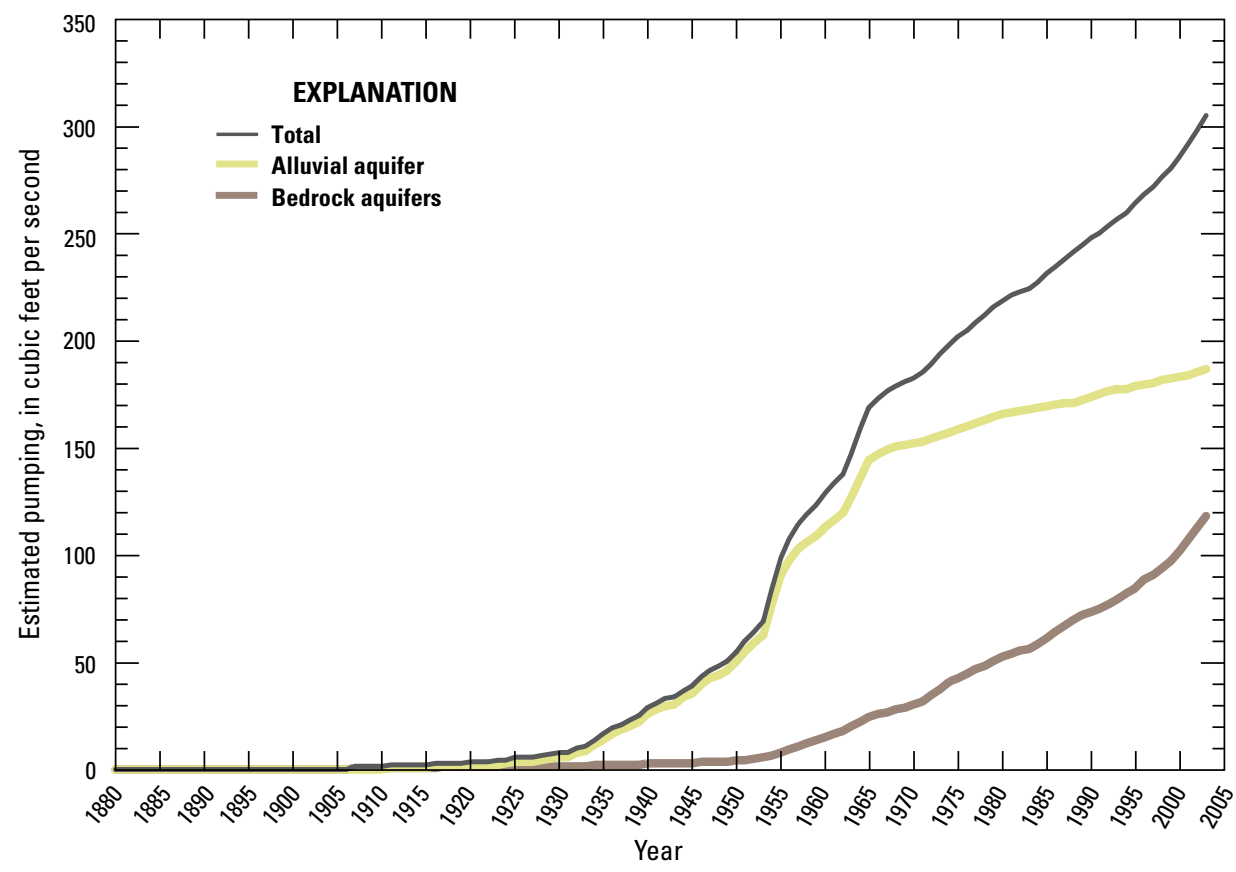

From Paschke (2011)

Figure 7. Total estimated pumping from Denver Basin alluvial-aquifer and bedrock-aquifer wells, Denver Basin aquifer system, Colorado, 1880-2003.

aquifers, more water is produced from the alluvial aquifer (Paschke, 2011) (fig. 8A). The most recent (2003) estimates of basinwide pumping (Paschke, 2011, fig. 8) indicated that water use is dominated by irrigation (62 percent), followed by municipal ( 20 percent), domestic (12 percent), and commercial/industrial uses (6 percent) (fig. $8 B$ ). Pumping estimates for 2003 indicate that the Arapahoe aquifer was the most heavily pumped of the bedrock aquifers, followed by the Denver, Dawson, and Laramie-Fox Hills aquifers (Paschke, 2011) (fig. 8C). The Arapahoe and Laramie-Fox Hills aquifers primarily were used for municipal purposes, whereas the Dawson aquifer primarily was used for domestic purposes (Paschke, 2011). Water use for the Denver aquifer was split nearly equally among municipal, domestic, and irrigation uses in 2003 (Paschke, 2011). Domestic wells in the bedrock aquifers are located throughout the basin and generally are completed in the aquifer nearest to the surface. Municipal wells in the bedrock aquifers tend to be located on the west side of the basin and are concentrated in the identified areas of recent urban and suburban development (fig. 6) (Paschke, 2011).

Development of groundwater resources in the basin has altered the groundwater flow system, including the groundwater budget and flow directions, as described by Paschke (2011), and summarized herein. The expansion of urban and suburban land use and irrigated agriculture since the 1950s has increased water use on the landscape, which has increased recharge, evapotranspiration, and the overall quantity of water recharging and discharging from the groundwater system in this semiarid region. Increased pumping from the bedrock aquifers (fig. 7), primarily in response to municipal water-supply needs in urbanized areas, has resulted in regional lowering of hydraulic heads and removal of water from storage when compared to predevelopment conditions. The alluvial aquifer, with shallow depths to water, receives more irrigation return flow than do the bedrock aquifers, such that recharge, evapotranspiration, and groundwater/surface-water interaction also are greater for the alluvial aquifer than for the bedrock aquifers. These factors, combined with the high hydraulic conductivity of the alluvial aquifer, have resulted in minimal changes to the potentiometric surface and storage in the alluvial aquifer in response to pumping. In contrast, the bedrock aquifers receive little precipitation recharge because of overlying confining units, low precipitation rates, and high evapotranspiration rates. These factors, combined with low hydraulic conductivity values for the bedrock aquifers relative to the alluvial aquifer, have resulted in substantial drawdown of potentiometric surfaces, increased areas of unconfined conditions, reduced flow to the alluvial aquifer, and removal of water from storage in response to pumping from the bedrock aquifers. 
Denver Basin wells, 2003

\section{A. Denver Basin aquifer system}

\section{EXPLANATION}

Denver Basin aquifer system

Alluvial aquifer

Bedrock aquifers in alluvial aquifer

\section{Estimated pumping from \\ Denver Basin wells,}

2003

15 percent of basin wells completed

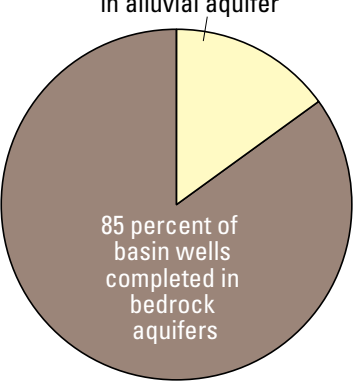

Total Denver Basin wells in this analysis (52,000 wells), 2003

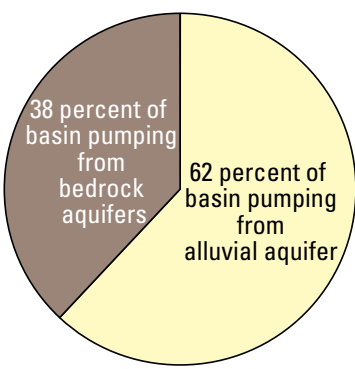

Total estimated pumping from Denver Basin alluvial and bedrock wells (305 cubic feet per second [ $\left.\mathrm{ft}^{3} / \mathrm{s}\right]$ ), 2003

\section{B. Water use in Denver Basin, 2003}

\section{Alluvial aquifer}

\section{EXPLANATION}

\section{Water use}

Irrigation

Municipal

Domestic

Commercial/industria

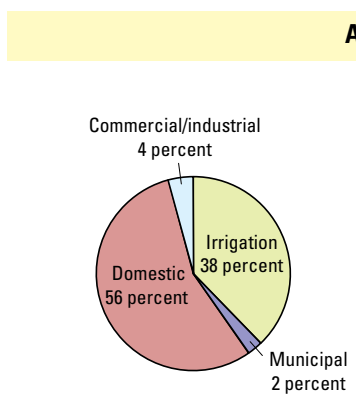

Denver Basin alluvial wells $(7,867$ wells categorized by water use

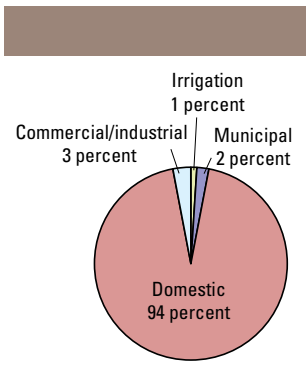

Denver Basin bedrock wells (44,149 wells) categorized by water use

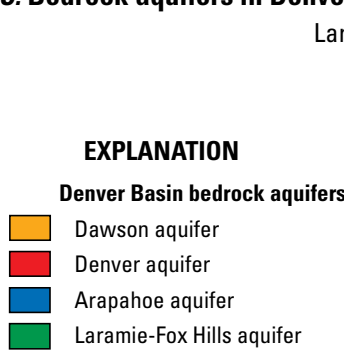

C. Bedrock aquifers in Denver Basin, 2003

\section{Bedrock aquifers}

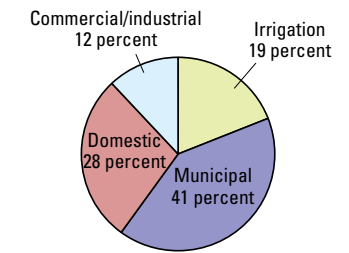

Estimated pumping from Denver Basin bedrock wells $\left(118 \mathrm{ft}^{3} / \mathrm{s}\right)$ categorized by water use

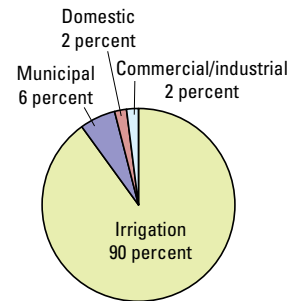

Estimated pumping from Denver Basin alluvial wells (187 ft $3 / \mathrm{s})$ categorized by water use
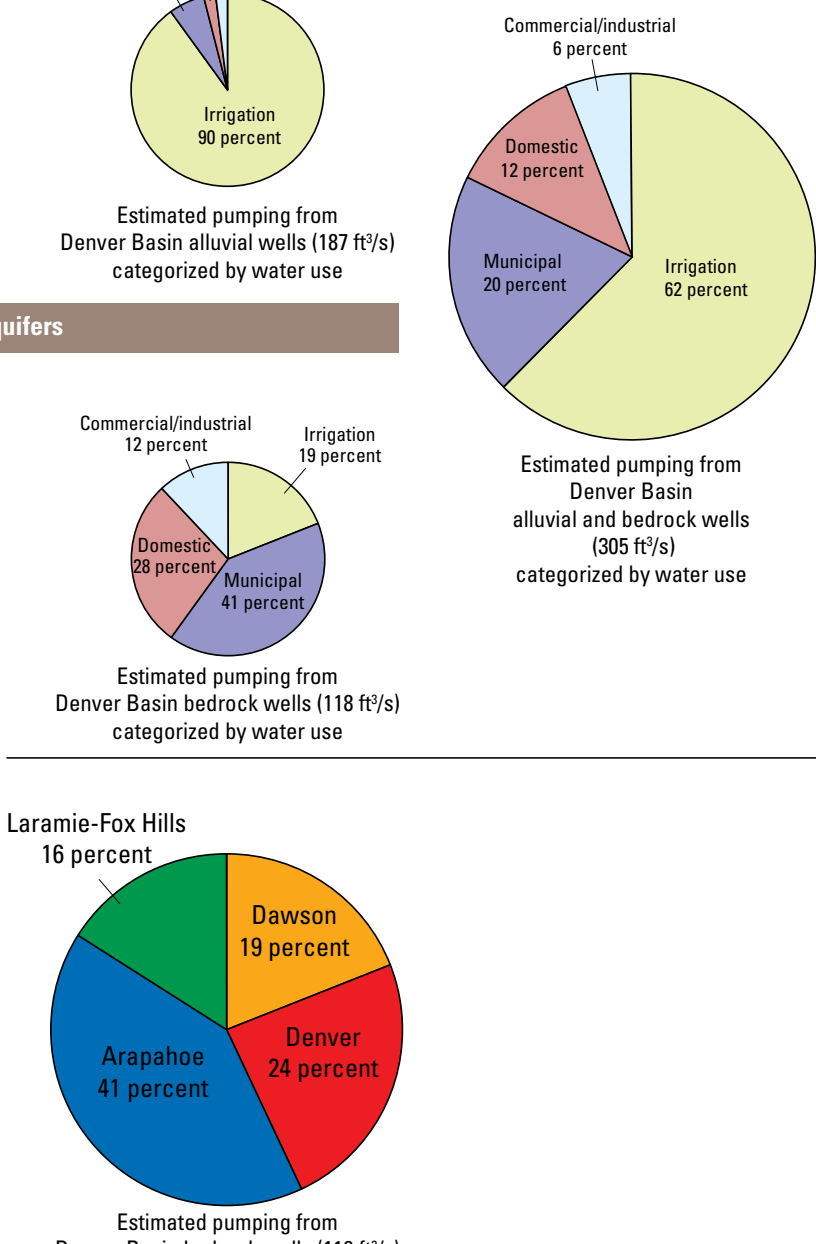

Denver Basin bedrock wells $\left(118 \mathrm{ft}^{3} / \mathrm{s}\right)$ categorized by aquifer

Figure 8. Percentages of wells and estimated pumping from the Denver Basin aquifer system, Colorado, 2003. $A$, Basinwide. $B, B y$ water use. $C$, By bedrock aquifer. 
Alteration to the groundwater flow system, as simulated by an increase in urban and agricultural recharge with a groundwater-flow model by Paschke (2011), can potentially affect water quality for the alluvial and bedrock aquifers. Increased recharge can transport natural constituents, such as trace elements and salts, and human-sourced contaminants from the unsaturated zone to the water table. Under natural conditions, groundwater in the bedrock aquifers is considered less vulnerable to contamination from the land surface because of low recharge rates and impermeable confining layers separating them from the shallow groundwater system. Modeling results indicate, however, that pumping from wells in the bedrock aquifers has increased drawdown in bedrock potentiometric surfaces, which has increased downward interaquifer flow between aquifers (Paschke, 2011). This alteration of natural groundwater flow can potentially result in poor quality groundwater in shallow parts of the aquifer system moving downward toward the bedrock aquifers.

\section{Previous Studies}

Previous studies of the Denver Basin and the surrounding region provide insight into the hydrology, water quality, and water availability of the region. Hydrogeologic characterizations of the Denver Basin aquifers were undertaken beginning in the 1970s, which resulted in hydrologic atlases of the geologic structure, hydrology, and water quality of the four bedrock aquifers (Robson, Romero, and others, 1981; Robson, Wacinski, and others, 1981; Robson and Romero, 1981a, 1981b, 1981c). A groundwater flow model for the Denver Basin aquifers was developed by Robson (1987). The hydrologic atlases were updated in 1988 (VanSlyke and others, 1988a, 1988b, 1988c, 1988d) and form the current basis for defining aquifer boundaries (Graham and VanSlyke, 2004). Robson (1989) evaluated alluvial and bedrock groundwater resources of the basin and noted poorer water quality and greater susceptibility of the alluvial aquifer to contamination.

Robson (1987) summarized typical water quality for groundwater of the four bedrock aquifers, noting generally good water quality throughout most of the Dawson, Denver, and Arapahoe aquifers. Major-ion chemistry generally evolved from a calcium (Ca)-bicarbonate $\left(\mathrm{HCO}_{3}\right)$ to a sodium ( $\mathrm{Na}$ ) $-\mathrm{HCO}_{3}$ composition with depth; the Dawson and Denver aquifers were primarily characterized by a $\mathrm{Ca}-\mathrm{HCO}_{3}$ composition with some $\mathrm{Na}-\mathrm{HCO}_{3}$ water near the aquifer margins. The Arapahoe and Laramie-Fox Hills aquifers were primarily characterized by a $\mathrm{Na}-\mathrm{HCO}_{3}$ composition; some groundwater with a Na-SO ${ }_{4}$ composition was also found near the aquifer margins, particularly for the Laramie-Fox Hills aquifer. TDS concentrations generally were higher in the deeper bedrock aquifers relative to shallower bedrock aquifers; for each individual aquifer, TDS concentrations generally were higher along the aquifer margins and near the northern edges relative to the center of the basin. Some high
Fe concentrations were found in scattered locations in all four aquifers. Water-rock interaction and ion-exchange processes decreased $\mathrm{Ca}$ concentrations and increased $\mathrm{Na}$ concentrations along flow paths (Robson, 1987). Water quality generally was degraded as water moved laterally toward the margins of each aquifer by surface recharge containing dissolved $\mathrm{SO}_{4}$ and other constituents leached from soluble minerals in the overlying soil and rock (Robson and Banta, 1995). Oxic water in the shallow aquifers was noted to evolve to anoxic (low dissolved oxygen [DO]) water with depth in the deeper aquifers; in the Laramie-Fox Hills aquifer, reducing (anoxic) conditions promote dissolution of Fe and Mn (Robson, Wacinski, and others, 1981; Robson and Romero, 1981a, 1981b, 1981c).

The effects of urbanization on groundwater quality at the water table in the South Platte River Basin (fig. 2), which partially overlaps the Denver Basin, were investigated as part of the NAWQA Program between 1993 and 1995 (Bruce and McMahon, 1998). Detections of pesticide compounds and VOCs in samples from the alluvial aquifer beneath areas of urban land use and agricultural land use indicated that human factors have influenced shallow groundwater quality (Bruce and McMahon, 1998). Contaminants such as U and $\mathrm{Rn}$, which occur naturally in the local rocks and sediments (Boberg and Runnells, 1971), were detected throughout the South Platte River Basin at relatively high concentrations that often exceeded established or proposed water-quality benchmarks; high $U$ concentrations for groundwater samples from the alluvial aquifer in urban land-use areas $(n=30)$ and in irrigated agricultural areas $(\mathrm{n}=30)$ (median values of 17 and 46.5 micrograms per liter $[\mu \mathrm{g} / \mathrm{L}]$, respectively) partially reflect relatively high $U$ background concentrations in Denver Basin sediment and rock (Bruce and McMahon, 1998). The differences between the urban and agricultural area are consistent with nationwide studies that indicate that groundwater from wells in agricultural settings tends to have higher $\mathrm{U}$ concentrations relative to urban land-use settings (Ayotte, Gronberg, and others, 2011). The waterquality results for irrigated agriculture described by Bruce and McMahon (1998) provide insight into the effects of irrigation in agricultural land-use settings when compared with the predominantly non-irrigated agricultural land-use results from the current study. Similarly, samples collected by Bruce and McMahon (1998) from the alluvial aquifer in urban land-use areas in the Denver metropolitan area are compared herein with urban land-use results from the current study, although direct comparison is not possible because the same wells were not sampled. Bails and others (2009) described the occurrence of selected organic compounds in samples from publicsupply wells in the Dawson and Denver aquifers. Several pesticides and VOCs were detected, although infrequently and at low concentrations (that is, at concentrations less than water-quality benchmarks), in samples from the Dawson aquifer; detected constituents included atrazine, its degradate deethylatrazine, prometon, trichloromethane (chloroform), tetrachloroethene (PCE), and methyl tert-butyl ether (MTBE) (Bails and others, 2009). 
Water quality of the alluvial aquifer in the region has been the focus of several studies. The groundwater quality of the alluvial aquifer affects surface-water quality because of groundwater discharge to surface-water bodies (McMahon and Böhlke, 1996; Bruce and McMahon, 1998; Dennehy and others, 1998). The effects of denitrification and mixing between streams and the alluvial aquifer in the region were investigated by McMahon and Böhlke (1996) in an area affected by agricultural irrigation to the north of Denver. Results indicated that denitrification and mixing within alluvial aquifer sediments decreased the $\mathrm{NO}_{3}$ load added to surface water by discharging groundwater. Paschke and others (2008) investigated temporal changes in $\mathrm{NO}_{3}$ and pesticide concentrations in the alluvial aquifer of the South Platte River Basin between 1993 and 2004. The South Platte River alluvial aquifer underlies an important agricultural area and is vulnerable to the effects of agricultural practices (Paschke and others 2008), which include increased agricultural irrigation recharge and associated use of agricultural chemicals. Paschke and others (2008) found that $\mathrm{NO}_{3}$ concentrations were higher in oxic conditions and that, based on nitrogen $(\mathrm{N})$ isotopes, synthetic fertilizer was a prominent $\mathrm{NO}_{3}$ source. Redox conditions were determined to be an important influence on redox-sensitive constituents such as $\mathrm{NO}_{3}$ and pesticides in the alluvial aquifer (Paschke and others, 2008).

Water-level declines associated with increased pumping for public supply from the Denver Basin bedrock aquifers are a concern for water-resource management in the region (Moore and others, 2004; Paschke, 2011). Much of the rapid population growth in the Denver Basin area is supported by groundwater resources (Moore and others, 2004), and pumping of groundwater from the bedrock aquifers has more than quadrupled since 1970 (Paschke, 2011) (fig. 7). Longterm water-level data have documented water-level declines of as much as hundreds of feet in some parts of the bedrock aquifers, which can affect groundwater availability, as well as discharge to the surficial system (Paschke, 2011). Groundwater availability in the Denver Basin was investigated by using a regional flow model by Paschke (2011) to assess the effects of groundwater resource development on aquifer sustainability. Changes in land and water use have altered the Denver Basin groundwater flow system compared to predevelopment conditions, resulting in increased groundwater availability in the alluvial aquifer and shallow parts of the hydrologic system and decreased groundwater availability in the bedrock aquifers (Paschke, 2011).

\section{Methods}

The USGS collected groundwater samples from the alluvial and bedrock aquifers of the Denver Basin during 2003-5 for studies done as part of the NAWQA Program (fig. 9; tables 2 and 3). Samples were collected (1) from monitoring wells completed at or just below the water table to evaluate the water quality of shallow groundwater beneath agricultural or urban land-use areas and (2) from domestic- and public-supply wells completed in the bedrock aquifers to evaluate the water quality of drinking water resources, specifically the Dawson, Denver, Arapahoe, and Laramie-Fox Hills aquifers.

\section{Well Networks and Installation}

Two monitoring-well networks (referred to hereinafter as "water-table wells") were installed in areas of (1) agricultural land use, predominantly non-irrigated wheat (and other small grain) crops (referred to as "agricultural land-use wells"), and (2) urban land use (referred to as "urban land-use wells") (fig. 9; tables 2 and 3). Monitoring-well locations were randomly distributed within the areas of targeted land use by following the methods of Scott (1990). Monitoring wells were completed at or just below the water table in either alluvial material or near-surface bedrock depending on where the water table was encountered. The agricultural land-use wells $(\mathrm{n}=31)$ were completed in alluvial material (that is, the alluvial aquifer) or the shallow Denver aquifer, which outcrops at the surface in the area of the network (figs. 5 and 9). In this setting, no supplemental irrigation water is used, but herbicide and fertilizers are applied as needed. The urban land-use wells $(n=29)$ were installed in areas that have been urbanized since 1970 in the south metropolitan area of Denver; wells were completed in alluvial material or the shallow Dawson aquifer, which outcrops at the surface in the area of the network (figs. 5 and 9). The agricultural and urban land-use wells were sampled primarily in 2003. A small subset of the water-table wells ( 1 agricultural and 5 urban land-use wells) were sampled repeatedly during 2003-5; the initial samples collected in 2003 are considered herein. Stable isotope values considered herein for the urban land-use wells are for samples collected in October 2005; no stable isotope values were analyzed for samples collected in 2003. Water-quality data for samples from the water-table wells are discussed separately and collectively for the agricultural and urban land-use wells.

The monitoring wells were completed by using 2 -inchdiameter, Schedule 40, threaded flush-joint polyvinyl chloride (PVC) casing and well screens in accordance with USGS protocols (Lapham and others, 1995) and State of Colorado well-drilling rules (Colorado Division of Water Resources, 2010). Borehole annular space was backfilled with 10-20 mesh silica sand to about $2 \mathrm{ft}$ above the screened interval. An estimated 2-ft thickness of hydrated 0.25 -inchdiameter bentonite pellets was added to seal the screened interval above the sand filter pack, and a high-density bentonite grout was used to seal the borehole annular space from the top of the bentonite pellets to near ground surface. The wells were developed by following USGS protocols (Lapham and others, 1995). During well development, physicochemical properties (specifically, specific conductance, $\mathrm{DO}, \mathrm{pH}$, temperature, and turbidity) were monitored until values stabilized. Monitoring-well depths were relatively shallow, ranging from 18.7 to $113 \mathrm{ft}$, with a median depth of $54.0 \mathrm{ft}$ (table 3 ). The screened-interval length for the watertable wells ranged from 9.50 to $10.0 \mathrm{ft}$ (table 3 ). 


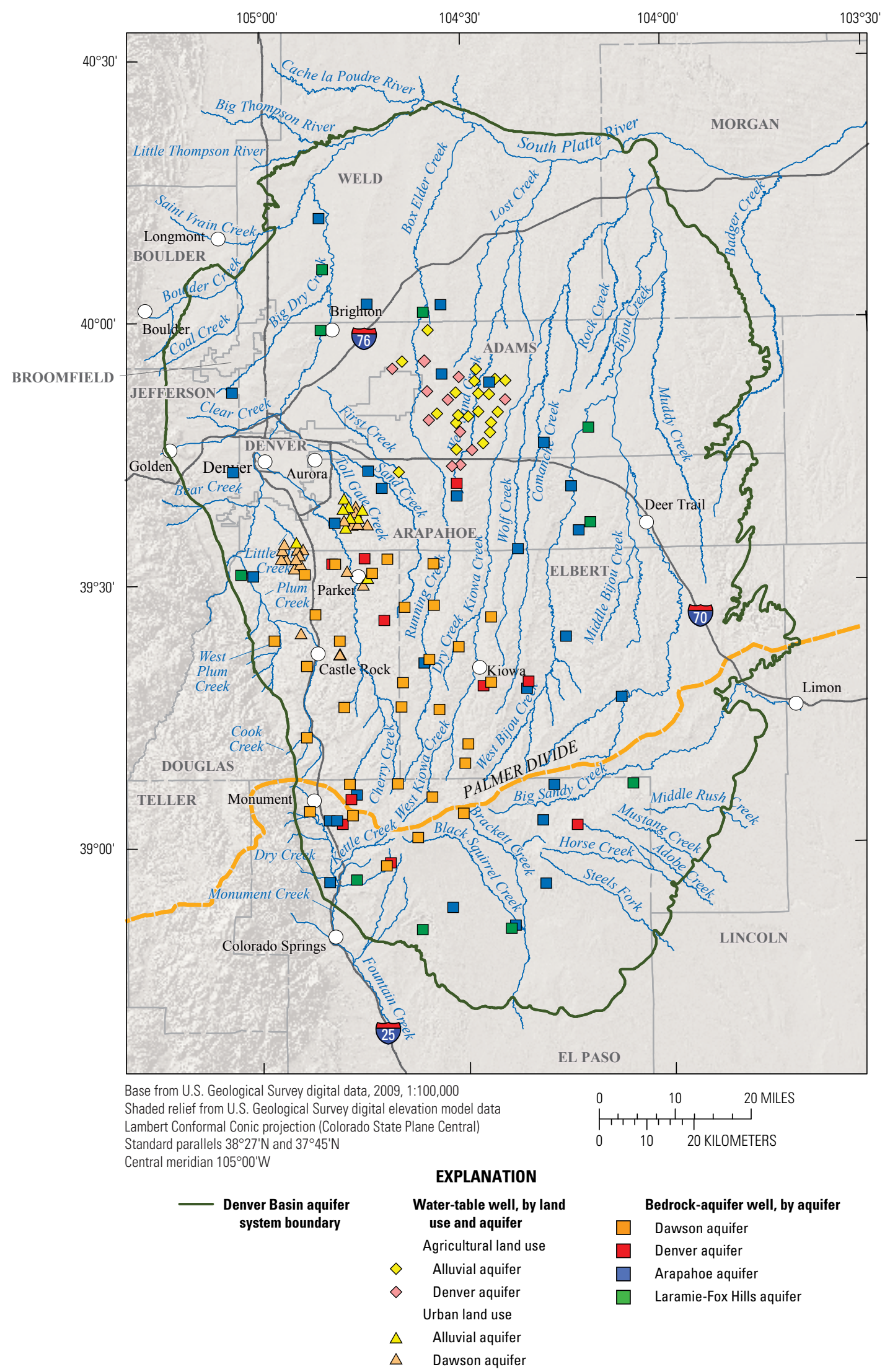

Figure 9. Hydrogeologic setting and locations of groundwater wells sampled for water quality, Denver Basin aquifer system, Colorado, 2003-5. 
Table 2. Summary of water-quality studies and data collected for National Water-Quality Assessment Program studies, Denver Basin aquifer system, Colorado, 2003-5.

[x, sampled; --, not sampled; P, a subset of wells were sampled, and a partial dataset exists; ft, feet; $\delta \mathrm{D}$, delta deuterium; $\delta^{18} \mathrm{O}$, delta oxygen-18; $\delta^{13} \mathrm{C}$, delta carbon-13; ${ }^{3} \mathrm{H}$, tritium; ${ }^{14} \mathrm{C}$, carbon-14]

\begin{tabular}{|c|c|c|c|c|c|c|c|c|c|c|c|c|c|c|c|c|}
\hline \multirow[b]{2}{*}{$\begin{array}{l}\text { Land use } \\
\text { or aquifer }\end{array}$} & \multirow[b]{2}{*}{ Description } & \multirow[b]{2}{*}{$\begin{array}{c}\text { Well } \\
\text { type(s) }\end{array}$} & \multirow[b]{2}{*}{$\begin{array}{l}\text { Num- } \\
\text { ber of } \\
\text { wells } \\
\text { sam- } \\
\text { pled }\end{array}$} & \multirow[b]{2}{*}{$\begin{array}{l}\text { Range } \\
\text { of well } \\
\text { depths } \\
\text { (ft below } \\
\text { land } \\
\text { surface) }\end{array}$} & \multirow[b]{2}{*}{$\begin{array}{c}\text { Dates } \\
\text { sampled }\end{array}$} & \multicolumn{11}{|c|}{ Chemical constituents } \\
\hline & & & & & & $\begin{array}{l}\text { Physico- } \\
\text { chemical } \\
\text { consti- } \\
\text { tuents } \\
\text { and major } \\
\text { ions }\end{array}$ & $\begin{array}{l}\text { Nutri- } \\
\text { ents }\end{array}$ & $\begin{array}{l}\text { Trace } \\
\text { ele- } \\
\text { ments }\end{array}$ & Radon & $\begin{array}{l}\text { Pesti- } \\
\text { cides }\end{array}$ & $\begin{array}{l}\text { Volatile } \\
\text { organic } \\
\text { com- } \\
\text { pounds }\end{array}$ & $\begin{array}{l}\delta D \\
\delta^{18} 0\end{array}$ & $\delta^{13} \mathrm{C}$ & $\begin{array}{c}\text { Age } \\
\text { tracers: } \\
{ }^{3} \mathrm{H}\end{array}$ & $\begin{array}{l}\text { Age } \\
\text { tracers: } \\
{ }^{14} \mathrm{C}\end{array}$ & $\begin{array}{l}\text { Age } \\
\text { tracers: } \\
\text { chloro- } \\
\text { fluoro- } \\
\text { carbons }\end{array}$ \\
\hline $\begin{array}{l}\text { Agricultural } \\
\text { land use }\end{array}$ & $\begin{array}{l}\text { Water-quality character- } \\
\text { ization of agricultural } \\
\text { areas to the east and } \\
\text { northeast of Denver, } \\
\text { primarily non-irrigated } \\
\text { wheat areas }\end{array}$ & $\begin{array}{l}\text { Water-table } \\
\text { monitoring } \\
\text { wells }\end{array}$ & 31 & $19-113$ & 2003 & $\mathrm{x}$ & $\mathrm{x}$ & $\mathrm{x}$ & -- & $\mathrm{x}$ & -- & $\mathrm{P}$ & -- & -- & -- & $\mathrm{P}$ \\
\hline $\begin{array}{l}\text { Urban land } \\
\text { use }\end{array}$ & $\begin{array}{l}\text { Water-quality character- } \\
\text { ization of areas of } \\
\text { recent urbanization to } \\
\text { the south of Denver, } \\
\text { Colorado }\end{array}$ & $\begin{array}{l}\text { Water-table } \\
\text { monitoring } \\
\text { wells }\end{array}$ & 29 & $19-82$ & ${ }^{1} 2003-5$ & $\mathrm{x}$ & $\mathrm{x}$ & $\mathrm{x}$ & -- & $\mathrm{x}$ & $\mathrm{x}$ & $\mathrm{P}^{1}$ & -- & -- & -- & $\mathrm{P}$ \\
\hline $\begin{array}{l}\text { Dawson } \\
\text { aquifer }\end{array}$ & $\begin{array}{l}\text { Water-quality character- } \\
\text { ization of the Dawson } \\
\text { aquifer as a regional } \\
\text { drinking-water resource }\end{array}$ & $\begin{array}{l}\text { Domestic } \\
\text { wells }\end{array}$ & 30 & $190-790$ & $2004-5$ & $\mathrm{x}$ & $\mathrm{x}$ & $\mathrm{x}$ & $\mathrm{x}$ & $\mathrm{x}$ & $\mathrm{x}$ & $\mathrm{P}$ & $\mathrm{P}$ & $\mathrm{P}$ & $\mathrm{P}$ & $\mathrm{P}$ \\
\hline $\begin{array}{l}\text { Denver } \\
\text { aquifer }\end{array}$ & $\begin{array}{l}\text { Water-quality character- } \\
\text { ization of the Denver } \\
\text { aquifer as a regional } \\
\text { drinking-water resource }\end{array}$ & $\begin{array}{l}\text { Domestic } \\
\text { wells }\end{array}$ & 10 & $\begin{array}{l}441- \\
1,150\end{array}$ & 2005 & $\mathrm{x}$ & $\mathrm{x}$ & $\mathrm{x}$ & -- & -- & -- & $\mathrm{P}$ & $\mathrm{P}$ & $\mathrm{P}$ & $\mathrm{P}$ & $\mathrm{P}$ \\
\hline $\begin{array}{l}\text { Arapahoe } \\
\text { aquifer }\end{array}$ & $\begin{array}{l}\text { Water-quality character- } \\
\text { ization of the Arapahoe } \\
\text { aquifer as a regional } \\
\text { drinking-water resource }\end{array}$ & $\begin{array}{l}\text { Domestic } \\
\text { and } \\
\text { public- } \\
\text { supply } \\
\text { wells }\end{array}$ & 29 & $\begin{array}{l}130- \\
2,149\end{array}$ & 2005 & $\mathrm{x}$ & $\mathrm{x}$ & $\mathrm{x}$ & $\mathrm{x}$ & $\mathrm{x}$ & $\mathrm{x}$ & $\mathrm{P}$ & $\mathrm{P}$ & $\mathrm{P}$ & $\mathrm{P}$ & $\mathrm{P}$ \\
\hline $\begin{array}{l}\text { Laramie- } \\
\quad \text { Fox Hills } \\
\text { aquifer }\end{array}$ & $\begin{array}{l}\text { Water-quality character- } \\
\text { ization of the Laramie- } \\
\text { Fox Hills aquifer as a } \\
\text { regional drinking-water } \\
\text { resource }\end{array}$ & $\begin{array}{l}\text { Domestic } \\
\text { wells }\end{array}$ & 10 & $\begin{array}{l}515- \\
1,450\end{array}$ & 2005 & $\mathrm{x}$ & $\mathrm{x}$ & $\mathrm{x}$ & -- & -- & -- & $\mathrm{x}$ & $\mathrm{x}$ & $\mathrm{x}$ & $\mathrm{x}$ & $\mathrm{P}$ \\
\hline
\end{tabular}

${ }^{1}$ Samples collected in 2003, except samples analyzed for $\delta \mathrm{D}$ and $\delta^{18} \mathrm{O}$, which were collected in 2005. 
Table 3. Site information for wells sampled in the Denver Basin aquifer system, Colorado, 2003-5.

[USGS, U.S. Geological Survey; NAD 83, North American Datum of 1983; NGVD 29, National Geodetic Vertical Datum of 1929; ft, feet; --, not available]

\begin{tabular}{|c|c|c|c|c|c|c|c|c|}
\hline $\begin{array}{l}\text { USGS station } \\
\text { number }\end{array}$ & $\begin{array}{l}\text { Local well } \\
\text { name }\end{array}$ & $\begin{array}{l}\text { Land use } \\
\text { or aquifer }\end{array}$ & $\begin{array}{c}\text { Latitude, } \\
\text { in decimal } \\
\text { degrees } \\
\text { (NAD } 83 \\
\text { datum) }\end{array}$ & $\begin{array}{c}\text { Longitude, } \\
\text { in decimal } \\
\text { degrees } \\
\text { (NAD } 83 \\
\text { datum) }\end{array}$ & $\begin{array}{l}\text { Land } \\
\text { surface } \\
\text { altitude } \\
\text { (ft above } \\
\text { NGVD 29) }\end{array}$ & $\begin{array}{c}\text { Well } \\
\text { depth } \\
\text { (ft below } \\
\text { land } \\
\text { surface) }\end{array}$ & \multicolumn{2}{|c|}{$\begin{array}{c}\text { Screened interval } \\
\text { (ft below land surface }\end{array}$} \\
\hline 394310104393401 & AGLUS 1 & Agricultural land use & 39.720 & 104.660 & 5,619 & 20.0 & 9.70 & 19.4 \\
\hline 395300104253301 & AGLUS 3 & Agricultural land use & 39.883 & 104.426 & 5,510 & 93.5 & 83.2 & 92.9 \\
\hline 395324104234301 & AGLUS 4 & Agricultural land use & 39.890 & 104.395 & 5,493 & 82.1 & 71.8 & 81.6 \\
\hline 395450104402701 & AGLUS 5 & Agricultural land use & 39.914 & 104.674 & 5,343 & 90.1 & 79.8 & 89.6 \\
\hline 395909104350401 & AGLUS 6 & Agricultural land use & 39.986 & 104.585 & 5,068 & 42.4 & 32.1 & 41.9 \\
\hline 395115104234401 & AGLUS 10 & Agricultural land use & 39.854 & 104.396 & 5,565 & 90.2 & 79.9 & 89.6 \\
\hline 394953104244601 & AGLUS 11 & Agricultural land use & 39.832 & 104.413 & 5,655 & 97.1 & 86.9 & 96.5 \\
\hline 394539104305901 & AGLUS 12 & Agricultural land use & 39.761 & 104.517 & 5,550 & 44.4 & 34.2 & 43.9 \\
\hline 394731104260001 & AGLUS 13 & Agricultural land use & 39.792 & 104.433 & 5,434 & 84.3 & 74.0 & 83.7 \\
\hline 394947104335201 & AGLUS 14 & Agricultural land use & 39.830 & 104.565 & 5,450 & 33.4 & 23.1 & 32.8 \\
\hline 395119104321001 & AGLUS 15 & Agricultural land use & 39.855 & 104.536 & 5,343 & 72.7 & 62.4 & 72.1 \\
\hline 394933104304101 & AGLUS 16 & Agricultural land use & 39.826 & 104.512 & 5,351 & 43.7 & 33.4 & 43.2 \\
\hline 395540104353601 & AGLUS 17 & Agricultural land use & 39.928 & 104.594 & 5,227 & 82.7 & 72.4 & 82.2 \\
\hline 394530104283901 & AGLUS 23 & Agricultural land use & 39.759 & 104.478 & 5,512 & 67.9 & 57.6 & 67.4 \\
\hline 394614104270701 & AGLUS 24 & Agricultural land use & 39.771 & 104.452 & 5,465 & 101 & 91.0 & 101 \\
\hline 394746104301901 & AGLUS 25 & Agricultural land use & 39.796 & 104.505 & 5,752 & 65.0 & 54.7 & 64.4 \\
\hline 394956104274101 & AGLUS 26 & Agricultural land use & 39.832 & 104.462 & 5,626 & 83.7 & 73.4 & 83.2 \\
\hline 395149104260701 & AGLUS 27 & Agricultural land use & 39.864 & 104.435 & 5,505 & 84.0 & 73.6 & 83.4 \\
\hline 395324104281401 & AGLUS 29 & Agricultural land use & 39.890 & 104.471 & 5,496 & 113 & 103 & 113 \\
\hline 395443104275901 & AGLUS 30 & Agricultural land use & 39.912 & 104.466 & 5,431 & 103 & 92.8 & 103 \\
\hline 395201104274001 & AGLUS REF1 & Agricultural land use & 39.867 & 104.461 & 5,278 & 73.3 & 58.1 & 67.8 \\
\hline 394351104302901 & AGLUS REF2 & Agricultural land use & 39.731 & 104.508 & 5,900 & 46.1 & 35.5 & 45.5 \\
\hline 393158104550701 & URLUS 1 & Urban land use & 39.533 & 104.919 & 5,937 & 77.5 & 67.2 & 77.0 \\
\hline 393301104561601 & URLUS 2 & Urban land use & 39.550 & 104.938 & 5,941 & 62.9 & 52.6 & 62.4 \\
\hline 393306104570201 & URLUS 3 & Urban land use & 39.552 & 104.951 & 5,884 & 81.7 & 71.5 & 81.1 \\
\hline 393404104565101 & URLUS 4 & Urban land use & 39.568 & 104.948 & 5,737 & 54.0 & 43.7 & 53.4 \\
\hline
\end{tabular}


Table 3. Site information for wells sampled in the Denver Basin aquifer system, Colorado, 2003-5.-Continued

[USGS, U.S. Geological Survey; NAD 83, North American Datum of 1983; NGVD 29, National Geodetic Vertical Datum of 1929; ft, feet; --, not available]

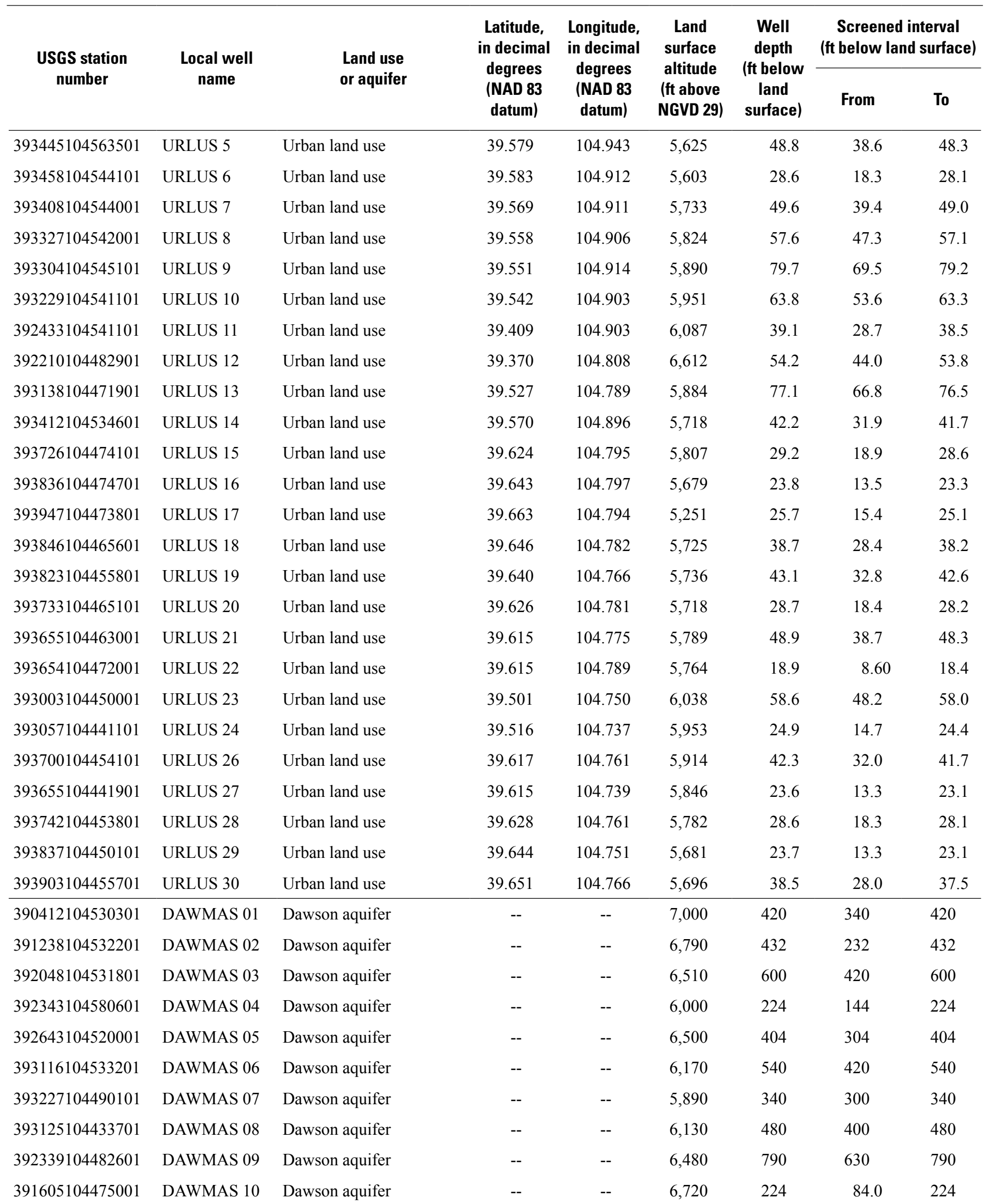


Table 3. Site information for wells sampled in the Denver Basin aquifer system, Colorado, 2003-5.-Continued

[USGS, U.S. Geological Survey; NAD 83, North American Datum of 1983; NGVD 29, National Geodetic Vertical Datum of 1929; ft, feet; --, not available]

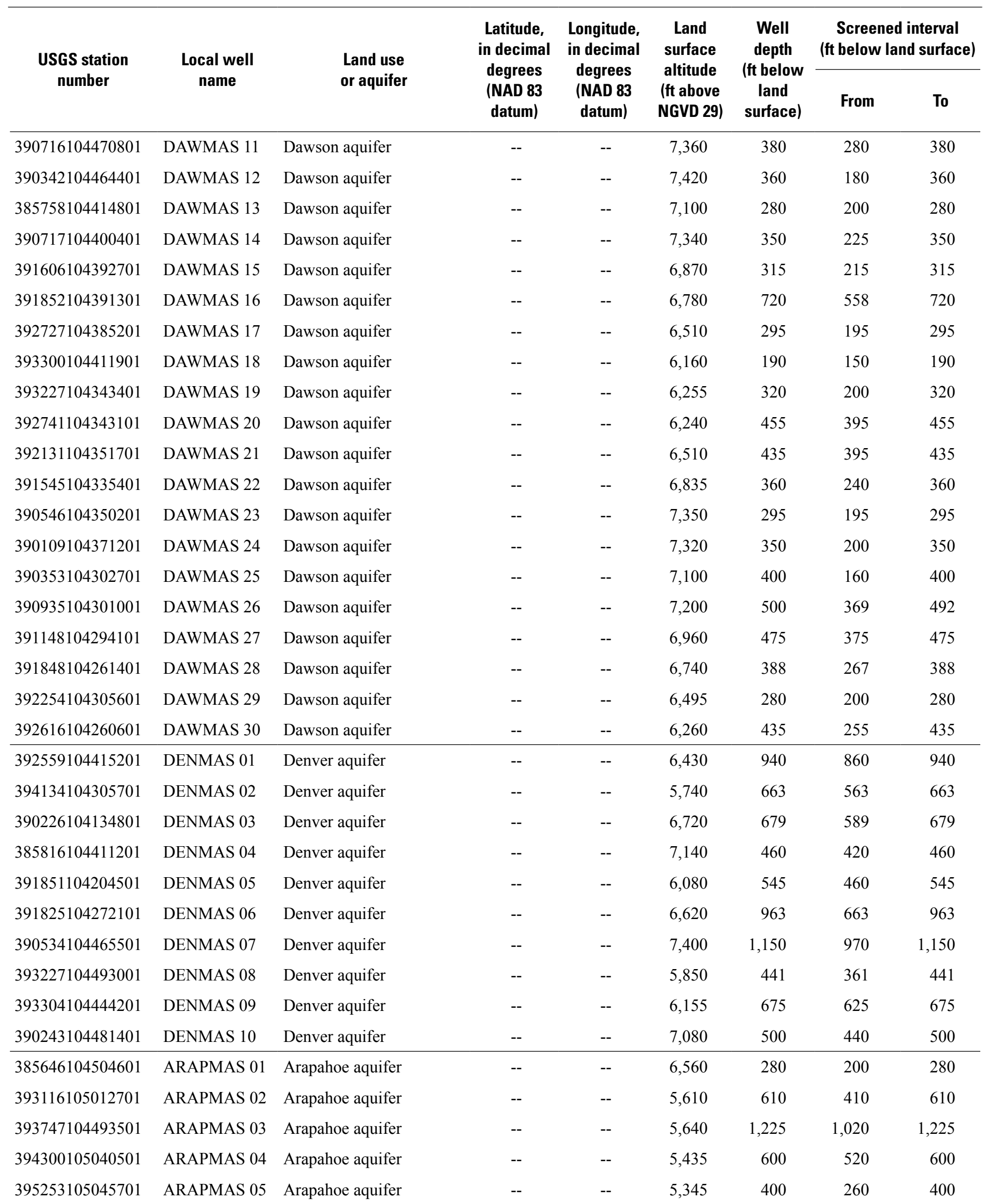


Table 3. Site information for wells sampled in the Denver Basin aquifer system, Colorado, 2003-5.-Continued

[USGS, U.S. Geological Survey; NAD 83, North American Datum of 1983; NGVD 29, National Geodetic Vertical Datum of 1929; ft, feet; --, not available]

\begin{tabular}{|c|c|c|c|c|c|c|c|c|}
\hline $\begin{array}{l}\text { USGS station } \\
\text { number }\end{array}$ & $\begin{array}{l}\text { Local well } \\
\text { name }\end{array}$ & $\begin{array}{l}\text { Land use } \\
\text { or aquifer }\end{array}$ & $\begin{array}{c}\text { Latitude, } \\
\text { in decimal } \\
\text { degrees } \\
\text { (NAD } 83 \\
\text { datum) }\end{array}$ & $\begin{array}{c}\text { Longitude, } \\
\text { in decimal } \\
\text { degrees } \\
\text { (NAD } 83 \\
\text { datum) }\end{array}$ & $\begin{array}{c}\text { Land } \\
\text { surface } \\
\text { altitude } \\
\text { (ft above } \\
\text { NGVD 29) }\end{array}$ & $\begin{array}{c}\text { Well } \\
\text { depth } \\
\text { (ft below } \\
\text { land } \\
\text { surface) }\end{array}$ & \multicolumn{2}{|c|}{$\begin{array}{c}\text { Screened interval } \\
\text { (ft below land surface) }\end{array}$} \\
\hline 395841104510901 & ARAPMAS 06 & Arapahoe aquifer & -- & -- & 4,990 & 440 & 260 & 440 \\
\hline 394346104442601 & ARAPMAS 08 & Arapahoe aquifer & -- & -- & 5,515 & 630 & 550 & 630 \\
\hline 394155104425401 & ARAPMAS 09 & Arapahoe aquifer & -- & -- & 5,590 & 1,090 & 960 & 1,090 \\
\hline 390348104501101 & ARAPMAS 10 & Arapahoe aquifer & -- & -- & 6,970 & 1,510 & 1,030 & 1,490 \\
\hline 390356104492001 & ARAPMAS 11 & Arapahoe aquifer & -- & -- & 7,230 & 1,755 & 1,315 & 1,745 \\
\hline 394058104312101 & ARAPMAS 16 & Arapahoe aquifer & -- & -- & 5,775 & 892 & 790 & 892 \\
\hline 395408104335301 & ARAPMAS 17 & Arapahoe aquifer & -- & -- & 5,300 & 440 & 380 & 440 \\
\hline 400202104335801 & ARAPMAS 18 & Arapahoe aquifer & -- & -- & 5,070 & 520 & 280 & 520 \\
\hline 395316104262201 & ARAPMAS 19 & Arapahoe aquifer & -- & -- & 5,190 & 400 & 340 & 400 \\
\hline 394618104184201 & ARAPMAS 20 & Arapahoe aquifer & -- & -- & 5,300 & 367 & 300 & 367 \\
\hline 393445104224201 & ARAPMAS 21 & Arapahoe aquifer & -- & -- & 5,700 & 282 & 182 & 282 \\
\hline 391834104205601 & ARAPMAS 22 & Arapahoe aquifer & -- & -- & 6,140 & 832 & 742 & 832 \\
\hline 390721104173801 & ARAPMAS 23 & Arapahoe aquifer & -- & -- & 6,550 & 805 & 685 & 805 \\
\hline 393617104131101 & ARAPMAS 29 & Arapahoe aquifer & -- & -- & 5,480 & 420 & 380 & 420 \\
\hline 394148104143401 & ARAPMAS 30 & Arapahoe aquifer & -- & -- & 5,235 & 320 & 280 & 320 \\
\hline 400111104354501 & LFHMAS 01 & Laramie-Fox Hills aquifer & -- & -- & 5,015 & 1,020 & 934 & 1,020 \\
\hline 395911104505901 & LFHMAS 02 & Laramie-Fox Hills aquifer & -- & -- & 5,050 & 1,000 & 800 & 1,000 \\
\hline 385056104231901 & LFHMAS 03 & Laramie-Fox Hills aquifer & -- & -- & 6,050 & 880 & 675 & 880 \\
\hline 394748104112301 & LFHMAS 04 & Laramie-Fox Hills aquifer & -- & -- & 5,055 & 515 & 410 & 515 \\
\hline 393659104111801 & LFHMAS 05 & Laramie-Fox Hills aquifer & -- & -- & 5,390 & 800 & 720 & 800 \\
\hline 385622104461201 & LFHMAS 06 & Laramie-Fox Hills aquifer & -- & -- & 6,740 & 1,450 & 1,300 & 1,450 \\
\hline 385036104364101 & LFHMAS 07 & Laramie-Fox Hills aquifer & -- & -- & 6,200 & 835 & 685 & 835 \\
\hline 390707104053001 & LFHMAS 08 & Laramie-Fox Hills aquifer & -- & -- & 6,160 & 683 & 593 & 683 \\
\hline 393114105025801 & LFHMAS 09 & Laramie-Fox Hills aquifer & -- & -- & 5,570 & 1,145 & 980 & 1,145 \\
\hline 400607104503901 & LFHMAS 10 & Laramie-Fox Hills aquifer & -- & -- & 4,910 & 590 & 510 & 590 \\
\hline
\end{tabular}


Wells completed in each of the bedrock aquifers (Dawson, Denver, Arapahoe, or Laramie-Fox Hills) were sampled during 2004 (Dawson aquifer) and 2005 (Denver, Arapahoe, and Laramie-Fox Hills aquifers) (fig. 9) (referred to hereinafter as "bedrock-aquifer wells"). A total of 79 domestic- or municipal-supply wells completed in the bedrock aquifers were sampled with a larger number of samples collected and analytes measured for the Dawson and Arapahoe aquifers (tables 2 and 3), which are more heavily pumped for water supply (Paschke, 2011). Selected well locations were randomly distributed throughout the aquifers by using the methods of Scott (1990). Preference was given, however, to wells constructed of PVC and with screened intervals of less than $50 \mathrm{ft}$ to minimize the effects of well-construction materials and mixing of groundwater from different intervals within the borehole. Screened-interval lengths ranged from 20 to $460 \mathrm{ft}$ (table 3); median values for bedrock aquifers were broadly similar $(110,83,102$, and 128 $\mathrm{ft}$ for the Dawson, Denver, Arapahoe, and Laramie-Fox Hills aquifers, respectively). Screened-interval length generally increased with well depth for the bedrock-aquifer wells (Kendall's tau $=0.30$; $\mathrm{p}$-value $<0.05$; Helsel and Hirsch, 2003, see "Water-Quality Data Presentation and Statistical Methods" section).

\section{Sample Collection and Analysis}

All samples were collected according to protocols developed for the NAWQA Program (Koterba and others, 1995; Lapham and others, 1995; Koterba, 1998; U.S. Geological Survey, variously dated). Additional protocols for age-tracer and dissolved-gas analyses are described by the U.S. Geological Survey Reston Chlorofluorocarbon Laboratory (2010). Where well access allowed, static waterlevel measurements were recorded prior to sample collection. Wells were purged prior to sampling; purged water from the wells was pumped through a flowthrough chamber to minimize contact with the atmosphere and was monitored for physicochemical properties. On the basis of established criteria in the USGS National Field Manual (U.S. Geological Survey, variously dated), well purging was considered complete after the removal of at least three well-casing volumes of water and after physicochemical properties stabilized. Physicochemical and field properties (air pressure, water temperature, DO, specific conductance, $\mathrm{pH}$, turbidity, and alkalinity) were measured in the field at the time of sample collection. Sample treatment and preservation methods and analytical methods are summarized in table 4. Samples were analyzed at several USGS laboratories, with most analyses completed at the USGS National Water Quality Laboratory (NWQL) in Denver (table 4). Analyzed constituents included major ions, nutrients, trace elements, pesticide compounds, VOCs, selected isotopes, and selected geochemical age tracers (table 4). Samples were analyzed on the basis of specific study objectives, and thus not all samples were analyzed for all constituents (table 2).

\section{Groundwater Age Tracers}

A variety of tracers of groundwater age, specifically chlorofluorocarbons (CFCs) (CFC-11, CFC-12, and CFC-113) and associated dissolved gases (carbon dioxide $\left[\mathrm{CO}_{2}\right]$, nitrogen $\left[\mathrm{N}_{2}\right]$, oxygen, and argon $\left.[\mathrm{Ar}]\right)$, tritium $\left({ }^{3} \mathrm{H}\right)$, and carbon-14 $\left({ }^{14} \mathrm{C}\right)$ were measured in selected samples. Human activities have released low concentrations of CFCs and ${ }^{3} \mathrm{H}$ into the atmosphere since the mid-1900s (Schlosser and others, 1988; Plummer and Busenberg, 2005). Precipitation incorporates these age tracers and ${ }^{14} \mathrm{C}$ from the atmosphere, and as a result, groundwater recharge carries a signature that can be related to atmospheric conditions at the time of recharge. Because the solubility of atmospheric tracers varies as a function of temperature, dissolved-gas concentrations were also measured. Young or modern groundwater is generally defined as post1950s recharge and is indicated by detections of CFCs and ${ }^{3} \mathrm{H}$ above appropriate concentrations (Clark and Fritz, 1997); for this report, post-1950s recharged groundwater is defined as young or modern. Radiocarbon dating using ${ }^{14} \mathrm{C}$ allows for investigation of the old (pre-1950s) fraction of recharge and was used to assess groundwater ages for older water samples, potentially thousands of years old, from the bedrock aquifers. For some mixed-age groundwater samples (that is, a mixture of young and old groundwater), $\mathrm{CFCs}$ and ${ }^{3} \mathrm{H}$ were used to estimate the age of the young water component, whereas ${ }^{14} \mathrm{C}$ measurements were used to estimate the age of the old water component. Although age-tracer results are obtained by highprecision measurements, each age-tracer technique relies on several assumptions and is potentially affected by various hydrologic or geochemical processes that, in combination, can greatly increase the uncertainty of the estimated age. Ages are estimated on the basis of models using simplifying assumptions of transport processes; as a result, age-tracer interpretations are model dependent (Cook and Böhlke, 2000; Plummer, 2005). 
Table 4. Analytes measured, sample treatment and preservation, and analytical methods for samples collected from the Denver Basin aquifer system, Colorado, 2003-5.

[USGS, U.S. Geological Survey; NWQL, National Water Quality Laboratory; $\mu \mathrm{m}$, micrometer; ${ }^{\circ} \mathrm{C}$, degrees Celsius; GC/MS, gas chromatography/mass spectrometry; LC/MS, liquid chromatography/mass spectrometry; HPLC/MS, high performance liquid chromatography/mass spectrometry; MS, mass spectrometry; <, less than; UV, ultraviolet; mL, milliliter; $\mu$ m, micrometer; $\mathrm{N}$, normality; $\mathrm{H}_{2} \mathrm{SO}{ }_{4}$, sulfuric acid; $\mathrm{HNO}_{3}$, nitric acid; $\mathrm{HCl}$, hydrochloric acid]

\begin{tabular}{|c|c|c|c|c|}
\hline $\begin{array}{l}\text { Physicochemical } \\
\text { properties, constituent, } \\
\text { or constituent group }\end{array}$ & $\begin{array}{l}\text { Sample treatment } \\
\text { and preservation } \\
\operatorname{method}(s)\end{array}$ & Analyzing laboratory & Analytical method(s) & Reference(s) \\
\hline $\begin{array}{l}\text { Dissolved oxygen, } \mathrm{pH} \text {, } \\
\text { specific conductance, } \\
\text { temperature, and turbidity }\end{array}$ & None & None; measurements made onsite & $\begin{array}{l}\text { Standard USGS methods as specified for } \\
\text { each of these physical properties }\end{array}$ & USGS (variously dated) \\
\hline $\begin{array}{l}\text { Dissolved solids and major } \\
\text { ions }\end{array}$ & $\begin{array}{l}0.45 \mu \mathrm{m} \text { filter; cations, } \\
\mathrm{HNO}_{3}\end{array}$ & $\begin{array}{l}\text { USGS NWQL, Lakewood, } \\
\text { Colorado }\end{array}$ & $\begin{array}{l}\text { Inductively coupled plasma, ion chromatog- } \\
\text { raphy }\end{array}$ & $\begin{array}{l}\text { Fishman and Friedman (1989); Fishman } \\
\text { (1993); American Public Health Associa- } \\
\text { tion (1998) }\end{array}$ \\
\hline Carbonate alkalinity & $0.45 \mu \mathrm{m}$ filter & Onsite & Inflection point titration & USGS (variously dated) \\
\hline Nutrients & $0.45 \mu \mathrm{m}$ filter & USGS NWQL, Lakewood, Colo. & Various & Fishman (1993); Patton and Kryskalla (2003) \\
\hline Trace elements & $0.45 \mu \mathrm{m}$ filter, $\mathrm{HNO}_{3}$ & USGS NWQL, Lakewood, Colo. & $\begin{array}{l}\text { Inductively coupled plasma, atomic absorp- } \\
\text { tion spectrometry }\end{array}$ & $\begin{array}{l}\text { Fishman and Friedman (1989); Faires (1993); } \\
\text { McLain (1993); Garbarino (1999) }\end{array}$ \\
\hline $\begin{array}{l}\text { Dissolved organic carbon } \\
\text { (DOC) }\end{array}$ & $\begin{array}{l}0.7 \mu \mathrm{m} \text { baked glass- } \\
\text { fiber filter, } \mathrm{H}_{2} \mathrm{SO}_{4}\end{array}$ & USGS NWQL, Lakewood, Colo. & $\begin{array}{l}\text { UV-light promoted persulfate oxidation and } \\
\text { infrared spectrometry }\end{array}$ & Brenton and Arnett (1993) \\
\hline $\begin{array}{l}\text { Pesticides ( } 45 \text { selected com- } \\
\text { pounds analyzed) }\end{array}$ & $\begin{array}{l}0.7 \mu \mathrm{m} \text { baked glass- } \\
\text { fiber filter }\end{array}$ & USGS NWQL, Lakewood, Colo. & $\begin{array}{l}\text { C-18 solid-phase extraction and capillary- } \\
\text { column GC/MS; graphitized carbon-based } \\
\text { solid-phase extraction and HPLC/MS }\end{array}$ & $\begin{array}{l}\text { Zaugg and others (1995); Lindley and others } \\
\text { (1996); Madsen and others (2003); Furlong } \\
\text { and others (2001) }\end{array}$ \\
\hline $\begin{array}{l}\text { Volatile organic compounds } \\
\text { (VOCs) ( } 86 \text { selected } \\
\text { compounds analyzed) }\end{array}$ & $\mathrm{HCl}$ & USGS NWQL, Lakewood, Colo. & Purge and trap capillary-column GC/MS & Connor and others (1998) \\
\hline $\begin{array}{l}\text { Hydrogen and oxygen } \\
\text { isotopes }\end{array}$ & None & $\begin{array}{l}\text { USGS Reston Stable Isotope } \\
\text { Laboratory, Reston, Virginia }\end{array}$ & $\begin{array}{l}\text { Gaseous hydrogen equilibration procedure; } \\
\text { carbon dioxide-water equilibration tech- } \\
\text { nique; isotope-ratio MS }\end{array}$ & $\begin{array}{l}\text { Coplen and others (1991); Epstein and } \\
\text { Mayeda (1953) }\end{array}$ \\
\hline Carbon isotopes & $0.45 \mu \mathrm{m}$ filter & $\begin{array}{l}\text { University of Waterloo Environ- } \\
\text { mental Isotope Laboratory, } \\
\text { Ontario, Canada }\end{array}$ & Isotope-ratio MS & Drimmie and others (1994) \\
\hline $\begin{array}{l}\text { Age tracers (dissolved gases } \\
\text { and CFCs) }\end{array}$ & None & $\begin{array}{l}\text { USGS Clorofluorocarbon Labora- } \\
\text { tory, Reston, Va. }\end{array}$ & Purge and trap GC/MS & $\begin{array}{l}\text { Bullister (1984); Bullister and Weiss (1988); } \\
\text { Plummer and Busenberg (2008a); Plum- } \\
\text { mer and Busenberg (2008b); USGS Reston } \\
\text { Chlorofluorocarbon Laboratory (2010) }\end{array}$ \\
\hline Age tracers (tritium) & None & $\begin{array}{l}\text { USGS Isotope Tracers Laboratory, } \\
\text { Menlo Park, California }\end{array}$ & $\begin{array}{l}\text { Electrolytic enrichment and analysis by } \\
\text { liquid scintillation counting }\end{array}$ & Thatcher and others (1977) \\
\hline Age tracers (carbon-14) & $0.45 \mu \mathrm{m}$ filter & $\begin{array}{l}\text { University of Waterloo Environ- } \\
\text { mental Isotope Laboratory, } \\
\text { Ontario, Canada }\end{array}$ & Accelerator MS & Drimmie and others (1994) \\
\hline
\end{tabular}




\section{Chlorofluorocarbons}

CFCs are stable, synthetic organic compounds that were developed in the early 1930s for refrigeration and have been used in a wide range of industrial and refrigerant applications (Plummer and Friedman, 1999). Groundwater age interpretation with CFCs is affected by recharge temperature, excess air (air trapped in pores that can be subsequently dissolved in groundwater, resulting in concentrations that exceed air-water equilibrium), and recharge altitude or elevation (Plummer and Busenberg, 2005). Dissolvedgas concentrations were used to estimate these factors as described by Busenberg and Plummer (1992) and Plummer and Busenberg (2005). Recharge altitude was assumed equal to land-surface altitude at each sampling site. A large range of altitude occurs across the study area, resulting in a range of recharge altitudes, from 4,910 to 7,420 ft. For recharge prior to 1987 , the sensitivity of CFC model ages for variability of $\pm 1,000$ meters (about $3,300 \mathrm{ft}$ ) is on the order of a few years; CFC model ages are more sensitive to recharge altitudes for post-1990 recharge (Plummer, 2005). Uncertainties in recharge altitude could affect model ages by up to a few years, particularly for younger samples. Dissolved-gas concentrations were not measured for most of the water-table well samples; where dissolved-gas data were not measured, recharge temperatures were assigned on the basis of calculated values for other samples in the agricultural or urban land-use well networks for which dissolved-gas concentrations were measured. For water-table well samples where excess air was not determined, the effect of excess air on the age estimation was not considered, and as a result estimated $\mathrm{CFC}$ ages might be younger than the actual ages (Busenberg and Plummer, 1992). Although this estimation is an additional uncertainty in age estimates for these samples, where excess air was determined for water-table well samples the concentrations were relatively low (2.8-3.3 cubic centimeters at standard pressure and temperature per liter) and thus not likely to markedly affect CFC age estimates; effects of excess air on CFC model ages are generally less than 1 year for most groundwater (Busenberg and Plummer, 1992).

Additional factors, including CFC contamination and degradation, can affect age interpretations. Concentrations of CFCs that are greater than concentrations expected from atmospheric sources are considered contaminated and might be particularly associated with air or groundwater in urban areas. Sources of potential CFC contamination include seepage from septic tanks, landfills, leaking sewer lines, underground storage tanks, sewage effluent in rivers, and discharge or injection of industrial wastes (Plummer and Busenberg, 2005). CFC contamination in groundwater has been documented in several studies in a variety of aquifer settings (for example, Thompson and Hayes, 1979; Busenberg and others, 1993; Böhlke and others, 1997). CFCs are subject to degradation processes under anoxic conditions, with $\mathrm{CFC}-11$ being the most rapidly degraded of the three CFCs (Cook and others, 2006). All but one sample from the Denver, Arapahoe, and Laramie-Fox Hills aquifers with CFC measurements had DO concentrations of less than 1 milligram per liter $(\mathrm{mg} / \mathrm{L})$ and, thus, might be affected by CFC degradation. A comparison of estimated ages based on the different CFCs, as well as plots of age-frequency distributions based on tracer-tracer graphs, for samples relative to historical CFC mixing ratios can provide insight into $\mathrm{CFC}$ degradation; these were evaluated for all samples. Where possible, CFC age estimates were based on CFC-12, which is the most stable of the CFCs in anoxic conditions (Plummer and Busenberg, 2005; Cook and others, 2006). For the current study, where anoxic conditions in the groundwater might have degraded CFCs, age estimates were noted as suspect; for two samples, CFC degradation was noted by the laboratory, and age determinations were rejected. For some samples, the measured CFC concentration was greater than that theoretically possible on the basis of equilibrium of the groundwater with the maximum atmospheric concentration; these concentrations were considered contaminated, and ages were not estimated.

Recharge temperature (the temperature of the water when it first entered the groundwater system, generally at the water table) is another source of uncertainty for CFC age estimates. Where the unsaturated zone is more than a few meters thick, the mean annual surface-soil temperature is generally within about 1 degree Celsius $\left({ }^{\circ} \mathrm{C}\right)$ of the recharge temperature (Cook and others, 2006). Anoxic conditions can also affect the estimation of recharge temperature because denitrification processes might affect dissolved $\mathrm{N}_{2}$; the conversion of $\mathrm{NO}_{3}$ to $\mathrm{N}_{2}$ can lead to an accumulation of $\mathrm{N}_{2}$ gas in excess of the calculated solubility equilibrium with the true recharge temperature. When $\mathrm{N}_{2}$ and $\mathrm{Ar}$ are used to determine recharge temperature, the calculated value is often erroneously high where denitrification has occurred. Groundwater recharged prior to 1970 is less sensitive to variations in recharge temperature than younger (post-1990) recharge, with effects on the order of 1 year or less (Plummer and Busenberg, 2005). For groundwater recharged after 1990, uncertainties in recharge temperature can result in larger errors in age estimates (Cook and others, 2006) but should not affect broad determination as to whether the sample is characterized as young groundwater.

\section{Tritium}

Atmospheric thermonuclear bomb testing during the $1950 \mathrm{~s}$ and $1960 \mathrm{~s}$ released ${ }^{3} \mathrm{H}$ to the atmosphere; concentrations peaked in 1963 (Clark and Fritz, 1997) and have since been decreasing. On the basis of its relatively short half-life (12.3 years), the presence of ${ }^{3} \mathrm{H}$ in groundwater is indicative of young groundwater recharge (Clark and Fritz, 1997; Plummer, 2005). Groundwater age interpretations with ${ }^{3} \mathrm{H}$ are qualitative. Water with a ${ }^{3} \mathrm{H}$ concentration greater than about 30 tritium units (TU) (1 TU equals 3.24 picocuries per liter $[\mathrm{pCi} / \mathrm{L}]$ ) likely contains a considerable component of bomb-pulse recharge, and water with no detected ${ }^{3} \mathrm{H}$ is considered old (pre-1950s, that is, prebomb) (Clark and Fritz, 1997). Groundwater recharged in the early 1950s (before thermonuclear bomb testing) would likely have a ${ }^{3} \mathrm{H}$ 
concentration of about 0.3 TU at most in $2004-5$ on the basis of its decay and estimates of the concentration in precipitation at that time. As a result, detection of ${ }^{3} \mathrm{H}$ in Denver Basin groundwater samples at a concentration greater than $0.3 \mathrm{TU}$ is likely indicative of at least a fraction of young (post-1950s) water. Tritium measurements also provide an independent check on $\mathrm{CFC}$ and ${ }^{14} \mathrm{C}$ groundwater age estimates.

\section{Carbon-14}

Carbon-14 data were collected to investigate the old (pre-1950s) fraction of recharge in the Denver Basin. The radionuclide ${ }^{14} \mathrm{C}$ in groundwater is transported as dissolved inorganic carbon (DIC) or dissolved organic carbon (DOC) and decays on the basis of a half-life of 5,730 years (Clark and Fritz, 1997). Carbon-14 is measured for DIC and is typically expressed as a percent of the initial ${ }^{14} \mathrm{C}$ activity (that is, as percent modern carbon [ $\mathrm{pmC}]$ ); results can be used to estimate groundwater ages ranging from about 1,000 to about 30,000 years (Clark and Fritz, 1997). By laboratory convention, reported values for ${ }^{14} \mathrm{C}$ are normalized for carbon-13 $\left({ }^{13} \mathrm{C}\right)$ fractionation to a standard delta carbon-13 $\left(\delta^{13} \mathrm{C}\right)$ value of -25 per mil. In order to calculate ${ }^{14} \mathrm{C}$ ages for the current study, reported ${ }^{14} \mathrm{C}$ values were denormalized for ${ }^{13} \mathrm{C}$ fractionation by using the calculation described in Stuiver and Polach (1977) and Plummer and others (2004). Although the correction typically results in small differences, it is appropriate to use the denormalized values, which represent the ${ }^{14} \mathrm{C}$ activity of the groundwater DIC (Plummer and others, 2004). Unadjusted radiocarbon ages, in years before present relative to $1950(t)$, were calculated as follows:

$$
t=\frac{5,568}{\ln (2)} \ln \left(\frac{100}{14 C}\right)-\frac{y-1950}{1.029}
$$

where

$$
\begin{aligned}
5,568 & \text { is the Libby half-life of }{ }^{14} \mathrm{C}, \\
100 & \text { is an assumed initial }{ }^{14} \mathrm{C} \text { activity of } 100 \mathrm{pmC} \\
& \text { (Plummer and others, 2004), } \\
y & \text { is the year of measurement, and } \\
1.029 & \text { is the ratio of the modern to Libby decay } \\
& \text { constants }\left(\lambda_{5,730} / \lambda_{5,568}\right) .
\end{aligned}
$$

In addition to consideration of radioactive decay, the interpretation of ${ }^{14} \mathrm{C}$ ages requires consideration of the many geochemical processes and reactions that can affect ${ }^{14} \mathrm{C}$ activity within groundwater. Uncertainties in ${ }^{14} \mathrm{C}$ dating result from (1) determining the initial ${ }^{14} \mathrm{C}$ content of recharge water and from (2) determining sources of carbon to the groundwater system that alter the initial ${ }^{14} \mathrm{C}$ concentration (Plummer and others, 1994). The geochemical model NETPATH applies a generalized quantitative inverse modeling approach to radiocarbon-dating adjustment based on geochemical mass transfers from tailored reaction paths in the aquifer (Plummer and others, 1994). This approach often results in corrections to the initial ${ }^{14} \mathrm{C}$ concentration $\left(\mathrm{A}_{0}\right)$ or to measured ${ }^{14} \mathrm{C}$ concentrations, which usually yield adjusted
${ }^{14} \mathrm{C}$ ages that are younger than those based only on ${ }^{14} \mathrm{C}$ decay. NetpathXL (Parkhurst and Charlton, 2008) was used to adjust ${ }^{14} \mathrm{C}$ ages on the basis of mass-balance models of geochemical mass transfers.

\section{Age-Tracer Interpretation}

Despite the analytical precision available for measurements of many geochemical age tracers, there are numerous uncertainties associated with groundwater age interpretations (Phillips and Castro, 2003; Bethke and Johnson, 2008). Age interpretation for a sample that consists of water of a single age might be relatively simple but becomes increasing complex for a sample that consists of a mixture of water; that is, a mixture of water "parcels," each of which has a discrete age (Böhlke, 2006). Lumped-parameter models for age tracers in water samples that consider the effects of hydrologic processes, such as dispersion and mixing, have been developed to facilitate interpretation of geochemical age tracers (Böhlke, 2006; Jurgens and others, 2012). Age-tracer concentrations were compared with results from different lumped-parameter models by using atmospheric input data for tracers and modeling software developed by Jurgens and others (2012). Available Northern Hemisphere atmospheric input and concentration histories for CFCs and ${ }^{14} \mathrm{C}$ were used as described by Jurgens and others (2012); for ${ }^{3} \mathrm{H}$, the input curve used was for the southwestern United States, specifically that developed for Albuquerque, New Mexico (Bexfield and others, 2012; Jurgens and others, 2012). Plots of age distributions based on tracer-tracer graphs for collected samples relative to theoretical curves for different lumped-parameter models provide insight into the distribution of ages in an aquifer, age mixtures at wells, and the representativeness of different hydrogeologic models of the flow system.

The program TracerLPM (Jurgens and others, 2012) was used to integrate results from different age tracers, in particular CFCs and ${ }^{3} \mathrm{H}$, and to evaluate lumped-parameter models for age interpretation. The simplest model that is commonly used to estimate groundwater age is piston flow, which assumes that tracer concentrations have not been affected by mixing or dispersion (Plummer and Busenberg, 2005). The piston-flow model can be a reasonable representation of age in some instances, such as for shallow wells with relatively short screened intervals (Jurgens and others, 2012). Mixing or dispersion, however, can affect tracer concentrations, particularly for wells with relatively long screened intervals. While all pumped groundwater is to some extent mixed in a well bore, wells with relatively long screened intervals can draw water of different ages from multiple parts of an aquifer and produce mixed apparent ages (Eberts and others, 2013). One model that describes effects of mixing on tracer concentrations is a binary-mixing model that assumes a sample is a mixture of young and old water (Plummer and Busenberg, 2005). The resulting model age is intermediate to those of the modeled endmembers. 


\section{Oxidation-Reduction Conditions}

Redox conditions were evaluated with the classification system of McMahon and Chapelle (2008) by using the software of Jurgens and others (2009), which is based on concentrations of DO and other redox elements. Redox conditions often change along groundwater flow paths because of the biological consumption of $\mathrm{DO}, \mathrm{NO}_{3}, \mathrm{Mn}, \mathrm{Fe}$, and $\mathrm{SO}_{4}$ as electron acceptors in microbially mediated reactions (Chapelle and others, 1995). Organic carbon is a common electron donor, supporting microbial metabolism. Changes in redox conditions proceed along a well-documented ecological succession of terminal electron-accepting processes, in which a single electron acceptor generally dominates at a time in a particular location (Chapelle and others, 1995; McMahon and Chapelle, 2008). Based on the energy gained from the reactions, the typical redox sequence observed in groundwater systems is from oxygen reducing, or oxic, to $\mathrm{NO}_{3}$ reducing, to $\mathrm{Mn}$ reducing (reduction of $\mathrm{Mn}$ oxides to $\mathrm{Mn}$ ), to $\mathrm{Fe}$ reducing (reduction of $\mathrm{Fe}$ oxides to $\mathrm{Fe}$ ), to $\mathrm{SO}_{4}$ reducing, and eventually to methanogenesis (McMahon and Chapelle, 2008). The reduction of $\mathrm{NO}_{3}, \mathrm{Mn}, \mathrm{Fe}, \mathrm{SO}_{4}$, and methane occurs in anoxic conditions $(<0.5 \mathrm{mg} / \mathrm{L} \mathrm{DO})$. Threshold values for classifying redox conditions as described by McMahon and Chapelle (2008) were used for the current study and were simplified to include oxic (greater than or equal to $[\geq] 0.5 \mathrm{mg} / \mathrm{L}$ ), anoxic $(<0.5 \mathrm{mg} / \mathrm{L})$, or mixed categories; the mixed category indicates that a sample is not diagnostic of a single redox process but instead might have two or more electron acceptors active in the same part of the aquifer. Mixed redox conditions might result from the mixing of groundwater, from the spatial heterogeneity in redox processes, or from well screens extending across more than one redox zone (McMahon and Chapelle, 2008).

\section{Water-Quality Data Presentation and Statistical Methods}

The NWQL uses both long-term method detection levels (LT-MDLs) and laboratory reporting levels (LRLs) when determining how to report water-quality data results (Childress and others, 1999). The LRL is generally twice the LT-MDL, where the LT-MDL is set to limit the chance of reporting a false positive (a reported detection for a sample when the analyte of interest is not actually present) to no greater than 1 percent (Childress and others, 1999). In general, when an analyte is not detected or is detected at a concentration less than the LT-MDL, the laboratory reports the analyte as less than (remark code of " $<$ ") the LRL, which limits the chance of a false negative result (not detecting the analyte when it is actually present in the sample) to no greater than 1 percent. A remark code of estimated ("E") is used when constituents are detected, but concentrations cannot be accurately quantified for a variety of reasons. An E code often indicates a reported concentration for a constituent that is greater than the LT-MDL but less than the LRL. For laboratory methods classified by the NWQL as "information-rich," which include methods used in the current study for pesticides and VOCs, estimated concentrations are reported even for analytes detected at concentrations less than the LT-MDL. For the current study, estimated values (E coded) were treated as quantitative values at the estimated (E coded) concentration. Most analytical data for the current study are available from the USGS National Water Information System (NWIS) (U.S. Geological Survey, 2012). Dissolved-gas and CFC data and quality-control data stored in USGS databases are available upon request.

Statistical methods were used to identify and characterize correlations between constituent concentrations of interest and potential explanatory variables. Nonparametric statistical tests were preferred and were used for most data interpretation; a nonnormal, or skewed, distribution is a common characteristic of water-resource data (Helsel and Hirsch, 2002), and as a result, nonparametric methods are generally better suited than are traditional parametric methods to evaluate water-resource data. The Kendall's tau coefficient is a nonparametric, rankbased test that measures the strength of the monotonic relation between two variables and is resistant to the effects of outliers (Helsel and Hirsch, 2002). The Kendall's tau coefficient ranges from -1 to 1 ; a value of 0 indicates no correlation, and values approaching -1 or 1 indicate an increasing strength of correlation. Kendall's tau coefficient values generally will be lower than those for traditional correlation coefficients for linear associations of the same strength; for example, a strong linear correlation of $\geq 0.9$ corresponds to a tau value of about $\geq 0.7$ (Helsel and Hirsch, 2002). Independent groups of data were compared for differences by using the MannWhitney $\mathrm{U}$ test; equivalent to the Wilcoxon rank-sum test, the Mann-Whitney U test assesses if two groups come from the same population (Helsel and Hirsch, 2002). For this report, statistical results with p-values less than 0.05 were considered statistically significant, and only significant relations are reported; as a result, no p-values are included when relations are reported.

Measured concentrations are compared to applicable regulatory and nonregulatory benchmarks, including maximum contaminant levels (MCLs), secondary maximum contaminant levels (SMCLs) (U.S. Environmental Protection Agency, 2011), and health-based screening levels (HBSLs) (Toccalino and others, 2004; Toccalino, 2007) (table 5). MCLs are legally enforceable drinking-water benchmarks for public drinking-water supply established by the U.S. Environmental Protection Agency (EPA). SMCLs are nonenforceable drinking-water benchmarks established by the EPA for constituents that may cause aesthetic or cosmetic effects. HBSLs are nonenforceable benchmarks developed by the USGS in collaboration with the EPA and others by using standard EPA methods and current toxicity information for many unregulated constituents and compounds for which regulatory benchmarks have not been established (Toccalino and others, 2004; Toccalino, 2007). HBSLs provide insight for assessment of potential human-health concerns and for further study or monitoring (Toccalino and others, 2004; Toccalino and others, 2012). 
Table 5. Summary statistics for well completion information, physicochemical properties, and selected geochemical constituents for groundwater samples from the Denver Basin aquifer system, Colorado, 2003-5.

[MCL, maximum contaminant level; SMCL, secondary maximum contaminant level; HBSL, health-based screening level; AMCL, alternative maximum contaminant level; mg/L, milligrams per liter; $\mu \mathrm{S} / \mathrm{cm}$, microsiemens per centimeter; FNU, formazin nephelometric units; ${ }^{\circ} \mathrm{C}$, degrees Celsius; $\mu \mathrm{g} / \mathrm{L}$, micrograms per liter; $\delta \mathrm{D}$, delta deuterium; $\delta^{18} \mathrm{O}$, delta oxygen-18; $\delta^{13} \mathrm{C}$, delta carbon- $13 ; \%$, per mil; pCi/L, picocuries per liter; $\mathrm{Ca}$, calcium; $\mathrm{Mg}$, magnesium; $\mathrm{HCO}_{3}$, bicarbonate; $\mathrm{Na}$, sodium; $\mathrm{Cl}$, chloride; $\mathrm{Br}$, bromide; $\mathrm{CaCO}_{3}$, calcium carbonate; $\mathrm{N}$, nitrogen; $\mathrm{P}$, phosphorus; min., minimum; max., maximum; na, no standard or not applicable; \%, percent; $<$, less than; --, not measured or not determined; $\mathrm{n}$, number of samples; =, equals; E, estimated]

\begin{tabular}{|c|c|c|c|c|c|c|c|c|}
\hline \multirow{3}{*}{ Constituent } & \multirow{3}{*}{ Units } & \multirow{3}{*}{$\begin{array}{c}\text { Benchmarks: } \\
\text { MCL, SMCL, or HBSL } \\
\text { (MCL unless otherwise noted) }\end{array}$} & \multicolumn{6}{|c|}{ Water-table wells } \\
\hline & & & \multicolumn{3}{|c|}{$\begin{array}{c}\text { Agricultural land use } \\
\text { ( } \mathrm{n}=31 \text { unless otherwise noted) }\end{array}$} & \multicolumn{3}{|c|}{$\begin{array}{c}\text { Urban land use } \\
\text { (n=29 unless otherwise noted) }\end{array}$} \\
\hline & & & Median & $\begin{array}{c}\text { Range } \\
\text { (min.-max.) }\end{array}$ & $\begin{array}{l}\text { Exceed- } \\
\text { ances } \\
(\%)^{1}\end{array}$ & Median & $\begin{array}{c}\text { Range } \\
\text { (min.-max.) }\end{array}$ & $\begin{array}{c}\text { Exceed- } \\
\text { ances } \\
(\%)^{1}\end{array}$ \\
\hline Well depth & feet & na & 73.3 & $18.7-113$ & na & 42.3 & $18.9-81.7$ & na \\
\hline $\begin{array}{l}\text { Screened interval } \\
\text { length }\end{array}$ & feet & na & 9.8 & $9.6-10.0$ & na & 9.8 & $9.5-9.8$ & na \\
\hline Dissolved oxygen & $\mathrm{mg} / \mathrm{L}$ & na & 7.2 & $0.4-17.4$ & na & 1.6 & $0.1-11.1$ & na \\
\hline $\mathrm{pH}$ & standard units & $6.5-8.5$ (SMCL) & 7.3 & $6.5-8.0$ & 0 & 7.0 & $5.9-8.0$ & 10 \\
\hline $\begin{array}{l}\text { Specific conduc- } \\
\text { tance }\end{array}$ & $\mu \mathrm{S} / \mathrm{cm}$ & na & 1,140 & $271-6,200$ & na & 1,150 & $408-4,900$ & na \\
\hline Temperature & ${ }^{\circ} \mathrm{C}$ & na & 16.7 & $12.6-22.5$ & na & 13.6 & $11.5-17.0$ & na \\
\hline Turbidity & FNU & na & 2.4 & $0.3-490$ & na & 2.0 & $0.2-57$ & na \\
\hline $\begin{array}{l}\text { Total dissolved } \\
\text { solids }\end{array}$ & $\mathrm{mg} / \mathrm{L}$ & 500 (SMCL) & 807 & $182-5,190$ & 61 & 717 & $294-4,410$ & 66 \\
\hline Calcium & $\mathrm{mg} / \mathrm{L}$ & na & 120 & $36.4-609$ & na & 159 & $53.7-706$ & na \\
\hline Magnesium & $\mathrm{mg} / \mathrm{L}$ & na & 27.6 & $5.6-203$ & na & 24.5 & $6.0-120$ & na \\
\hline Potassium & $\mathrm{mg} / \mathrm{L}$ & na & 5.07 & $1.36-40.6$ & na & 4.95 & $0.79-12.9$ & na \\
\hline Sodium & $\mathrm{mg} / \mathrm{L}$ & na & 64.4 & $8.2-930$ & na & 46.5 & $16.3-748$ & na \\
\hline Alkalinity & $\mathrm{mg} / \mathrm{L}$ as $\mathrm{CaCO}_{3}$ & na & 210 & $79-832$ & na & 200 & $22-535$ & na \\
\hline Bicarbonate & $\mathrm{mg} / \mathrm{L}$ & na & 256 & $96-1,010$ & na & 244 & $27-652$ & na \\
\hline Bromide & $\mathrm{mg} / \mathrm{L}$ & na & 0.49 & $0.05-4.51$ & na & 0.45 & $0.06-7.43$ & na \\
\hline Chloride & $\mathrm{mg} / \mathrm{L}$ & 250 (SMCL) & 37.4 & $3.95-542$ & 10 & 58.0 & $3.38-638$ & 10 \\
\hline Fluoride & $\mathrm{mg} / \mathrm{L}$ & 2 (SMCL), 4 & 0.32 & $<0.17-3.20$ & 3,0 & 0.64 & $0.17-1.39$ & 0,0 \\
\hline Silica & $\mathrm{mg} / \mathrm{L}$ & na & 20.7 & $9.3-27.4$ & na & 23.6 & $10.3-55.9$ & na \\
\hline Sulfate & $\mathrm{mg} / \mathrm{L}$ & 250 (SMCL) & 321 & $10.6-2,830$ & 52 & 225 & $39.4-2,260$ & 45 \\
\hline
\end{tabular}


Table 5. Summary statistics for well completion information, physicochemical properties, and selected geochemical constituents for groundwater samples from the Denver Basin aquifer system, Colorado, 2003-5.-Continued

[MCL, maximum contaminant level; SMCL, secondary maximum contaminant level; HBSL, health-based screening level; AMCL, alternative maximum contaminant level; mg/L, milligrams per liter; $\mu \mathrm{S} / \mathrm{cm}$, microsiemens per centimeter; FNU, formazin nephelometric units; ${ }^{\circ} \mathrm{C}$, degrees Celsius; $\mu \mathrm{g} / \mathrm{L}$, micrograms per liter; $\delta \mathrm{D}$, delta deuterium; $\delta^{18} \mathrm{O}$, delta oxygen- $18 ; \delta^{13} \mathrm{C}$, delta carbon- $13 ; \%$, per mil;

pCi/L, picocuries per liter; $\mathrm{Ca}$, calcium; $\mathrm{Mg}$, magnesium; $\mathrm{HCO}_{3}$, bicarbonate; $\mathrm{Na}$, sodium; $\mathrm{Cl}$, chloride; $\mathrm{Br}$, bromide; $\mathrm{CaCO}_{3}$, calcium carbonate; $\mathrm{N}$, nitrogen; $\mathrm{P}$, phosphorus; min., minimum; max., maximum; na, no standard or not applicable; \%, percent; <, less than; --, not measured or not determined; n, number of samples; =, equals; E, estimated]

\begin{tabular}{|c|c|c|c|c|c|c|c|c|}
\hline \multirow{3}{*}{ Constituent } & \multirow{3}{*}{ Units } & \multirow{3}{*}{$\begin{array}{c}\text { Benchmarks: } \\
\text { MCL, SMCL, or HBSL } \\
\text { (MCL unless otherwise noted) }\end{array}$} & \multicolumn{6}{|c|}{ Water-table wells } \\
\hline & & & \multicolumn{3}{|c|}{$\begin{array}{c}\text { Agricultural land use } \\
\text { (n=31 unless otherwise noted) }\end{array}$} & \multicolumn{3}{|c|}{$\begin{array}{c}\text { Urban land use } \\
\text { (n=29 unless otherwise noted) }\end{array}$} \\
\hline & & & Median & $\begin{array}{c}\text { Range } \\
\text { (min.-max.) }\end{array}$ & $\begin{array}{c}\text { Exceed- } \\
\text { ances } \\
(\%)^{1}\end{array}$ & Median & $\begin{array}{c}\text { Range } \\
\text { (min.-max.) }\end{array}$ & $\begin{array}{c}\text { Exceed- } \\
\text { ances } \\
(\%)^{1}\end{array}$ \\
\hline $\mathrm{Na} / \mathrm{Cl}$ & molar ratio & na & 3.9 & $1.0-14.2$ & na & 2.2 & $0.60-11.1$ & na \\
\hline$(\mathrm{Ca}+\mathrm{Mg}) / \mathrm{HCO}_{3}$ & molar ratio & na & 0.92 & $0.40-4.7$ & na & 0.97 & $0.49-12.9$ & na \\
\hline $\mathrm{Na} /(\mathrm{Ca}+\mathrm{Mg})$ & molar ratio & na & 0.69 & $0.31-4.8$ & na & 0.64 & $0.16-1.7$ & na \\
\hline $\mathrm{Cl} / \mathrm{Br}$ & molar ratio & na & 70 & $48-167$ & na & 95 & $50-242$ & na \\
\hline Ammonia & $\mathrm{mg} / \mathrm{L}$ as $\mathrm{N}$ & na & $<0.04$ & $<0.04-1.43$ & na & $<0.04$ & $<0.04-0.17$ & na \\
\hline Nitrate plus nitrite & $\mathrm{mg} / \mathrm{L}$ as $\mathrm{N}$ & na & 6.42 & $<0.06-31.9$ & na & 4.02 & $<0.06-24.2$ & na \\
\hline Nitrate & $\mathrm{mg} / \mathrm{L}$ as $\mathrm{N}$ & 10 & 6.42 & $<0.060-13.8$ & 19 & 4.02 & $<0.060-24.2$ & 17 \\
\hline Nitrite & $\mathrm{mg} / \mathrm{L}$ as $\mathrm{N}$ & 1 & $<0.008$ & $<0.008-0.795$ & 0 & $<0.008$ & $<0.008-0.282$ & 0 \\
\hline $\begin{array}{l}\text { Organic } \\
\text { nitrogen }\end{array}$ & $\mathrm{mg} / \mathrm{L}$ & na & $<0.09$ & $<0.05-2.3$ & na & $<0.01$ & $<0.01-0.48$ & na \\
\hline Orthophosphate & $\mathrm{mg} / \mathrm{L}$ as $\mathrm{P}$ & na & 0.030 & $<0.2-0.28$ & na & 0.012 & $<0.006-0.228$ & na \\
\hline $\begin{array}{l}\text { Dissolved organic } \\
\text { carbon }\end{array}$ & $\mathrm{mg} / \mathrm{L}$ & na & 2.98 & $0.58-81.9$ & na & 4.46 & $1.32-20.2$ & na \\
\hline$\delta^{18} \mathrm{O}$ & per mil (\%o) & na & $-13.73(n=8)$ & -16.79 to -12.52 & na & $-13.39(\mathrm{n}=5)$ & -14.69 to -12.79 & na \\
\hline$\delta \mathrm{D}$ & per mil (\%o) & na & $-104(n=8)$ & -126 to -97.9 & na & $-102(n=5)$ & -110 to -99.2 & na \\
\hline$\delta^{13} \mathrm{C}$ & per mil (\%o) & na & -- & -- & -- & -- & -- & -- \\
\hline Aluminum & $\mu \mathrm{g} / \mathrm{L}$ & 50-200 (SMCL) & 2.2 & $<3.2-7.1$ & 0 & 1.4 & $<1.6-27$ & 0 \\
\hline Barium & $\mu \mathrm{g} / \mathrm{L}$ & 2,000 & 54.3 & $9.71-243$ & 0 & 44.0 & $10.7-306$ & 0 \\
\hline Beryllium & $\mu \mathrm{g} / \mathrm{L}$ & 4 & $<0.060$ & $<0.060-\mathrm{E} 0.060$ & 0 & $<0.060$ & $<0.060-0.145$ & 0 \\
\hline Cadmium & $\mu \mathrm{g} / \mathrm{L}$ & 5 & 0.021 & $<0.037-0.23$ & 0 & $<0.040$ & $<0.040-\mathrm{E} 0.037$ & 0 \\
\hline Chromium & $\mu \mathrm{g} / \mathrm{L}$ & 100 & 1.0 & $<0.8-5.6$ & 0 & $<0.8$ & $<0.8-0.8$ & 0 \\
\hline Cobalt & $\mu \mathrm{g} / \mathrm{L}$ & na & 0.379 & $0.113-7.040$ & na & 0.623 & $0.15-9.65$ & na \\
\hline
\end{tabular}


Table 5. Summary statistics for well completion information, physicochemical properties, and selected geochemical constituents for groundwater samples from the Denver Basin aquifer system, Colorado, 2003-5.-Continued

[MCL, maximum contaminant level; SMCL, secondary maximum contaminant level; HBSL, health-based screening level; AMCL, alternative maximum contaminant level; mg/L, milligrams per liter; $\mu \mathrm{S} / \mathrm{cm}$, microsiemens per centimeter; FNU, formazin nephelometric units; ${ }^{\circ} \mathrm{C}$, degrees Celsius; $\mu \mathrm{g} / \mathrm{L}$, micrograms per liter; $\delta \mathrm{D}$, delta deuterium; $\delta^{18} \mathrm{O}$, delta oxygen-18; $\delta^{13} \mathrm{C}$, delta carbon- $13 ; \%$, per mil; pCi/L, picocuries per liter; $\mathrm{Ca}$, calcium; $\mathrm{Mg}$, magnesium; $\mathrm{HCO}$, bicarbonate; $\mathrm{Na}$, sodium; $\mathrm{Cl}$, chloride; $\mathrm{Br}$, bromide; $\mathrm{CaCO}_{3}$, calcium carbonate; $\mathrm{N}$, nitrogen; $\mathrm{P}$, phosphorus; min., minimum; max., maximum; na, no standard or not applicable; \%, percent; <, less than; --, not measured or not determined; n, number of samples; =, equals; E, estimated]

\begin{tabular}{|c|c|c|c|c|c|c|c|c|}
\hline \multirow{3}{*}{ Constituent } & \multirow{3}{*}{ Units } & \multirow{3}{*}{$\begin{array}{c}\text { Benchmarks: } \\
\text { MCL, SMCL, or HBSL } \\
\text { (MCL unless otherwise noted) }\end{array}$} & \multicolumn{6}{|c|}{ Water-table wells } \\
\hline & & & \multicolumn{3}{|c|}{$\begin{array}{c}\text { Agricultural land use } \\
\text { ( } \mathrm{n}=\mathbf{3 1} \text { unless otherwise noted) }\end{array}$} & \multicolumn{3}{|c|}{$\begin{array}{c}\text { Urban land use } \\
\text { ( } \mathrm{n}=29 \text { unless otherwise noted) }\end{array}$} \\
\hline & & & Median & $\begin{array}{c}\text { Range } \\
\text { (min.-max.) }\end{array}$ & $\begin{array}{l}\text { Exceed- } \\
\text { ances } \\
(\%)^{1}\end{array}$ & Median & $\begin{array}{c}\text { Range } \\
\text { (min.-max.) }\end{array}$ & $\begin{array}{c}\text { Exceed- } \\
\text { ances } \\
(\%)^{1}\end{array}$ \\
\hline Copper & $\mu \mathrm{g} / \mathrm{L}$ & 1,300 (action level) & 1.9 & $0.04-31.5$ & 0 & 2.0 & E0.3-10.3 & 0 \\
\hline Iron & $\mu \mathrm{g} / \mathrm{L}$ & 300 (SMCL) & 1.0 & $<10-3,880$ & 3 & 5.0 & $<6.4-27,300$ & 21 \\
\hline Lead & $\mu \mathrm{g} / \mathrm{L}$ & 15 (action level) & $<0.080$ & $<0.080-0.089$ & 0 & $<0.080$ & $<0.080-0.138$ & 0 \\
\hline Lithium & $\mu \mathrm{g} / \mathrm{L}$ & na & 27.0 & $9.35-137$ & na & 29 & $5.95-131$ & na \\
\hline Manganese & $\mu \mathrm{g} / \mathrm{L}$ & 50 (SMCL), 300 (HBSL) & 2.87 & $<0.18-2,500$ & 32,10 & 71.9 & $0.24-663$ & 52,17 \\
\hline Molybdenum & $\mu \mathrm{g} / \mathrm{L}$ & na & 2.50 & $0.417-9.48$ & na & 1.32 & $<0.80-10.4$ & na \\
\hline Nickel & $\mu \mathrm{g} / \mathrm{L}$ & na & 3.91 & $1.8-35.3$ & na & 2.49 & $<0.06-19.7$ & na \\
\hline Silver & $\mu \mathrm{g} / \mathrm{L}$ & 100 (SMCL and HBSL) & $<0.200$ & $<0.200-<0.600$ & 0 & $<0.200$ & $<0.200-<0.600$ & 0 \\
\hline Strontium & $\mu \mathrm{g} / \mathrm{L}$ & 4,000 (HBSL) & 1,340 & $381-12,400$ & 19 & 1,910 & $527-12,300$ & 14 \\
\hline Thallium & $\mu \mathrm{g} / \mathrm{L}$ & 2 & $<0.041$ & $<0.041-\mathrm{E} 0.060$ & 0 & $<0.040$ & $<0.040-0.099$ & 0 \\
\hline Vanadium & $\mu \mathrm{g} / \mathrm{L}$ & na & 1.8 & $0.3-10.7$ & na & 0.6 & $0.1-14.6$ & na \\
\hline Zinc & $\mu \mathrm{g} / \mathrm{L}$ & 2,000 (HBSL), 5,000 (SMCL) & 2.1 & $<1.0-16.3$ & 0,0 & 1.4 & $<0.6-19.9$ & 0,0 \\
\hline Antimony & $\mu \mathrm{g} / \mathrm{L}$ & 6 & $<0.300$ & $<0.300-0.62$ & 0 & $<0.200$ & $<0.200-\mathrm{E} 0.120$ & 0 \\
\hline Boron & $\mu \mathrm{g} / \mathrm{L}$ & na & 61 & $27-771$ & na & 59 & 19-292 & na \\
\hline Selenium & $\mu \mathrm{g} / \mathrm{L}$ & 50 & 6.2 & $<0.5-408$ & 16 & 9.7 & $<0.4-696$ & 21 \\
\hline Radon & $\mathrm{pCi} / \mathrm{L}$ & $300 ; 4,000{\text { (alternative } \mathrm{MCL})^{2}}^{2}$ & -- & -- & -- & -- & -- & -- \\
\hline Uranium & $\mu \mathrm{g} / \mathrm{L}$ & 30 & 6.8 & $0.13-146$ & 19 & 19.8 & $0.105-941$ & 34 \\
\hline Arsenic & $\mu \mathrm{g} / \mathrm{L}$ & 10 & 1.5 & E0.2-15.6 & 3 & 1.2 & $<0.2-87.5$ & 14 \\
\hline
\end{tabular}


Table 5. Summary statistics for well completion information, physicochemical properties, and selected geochemical constituents for groundwater samples from the Denver Basin aquifer system, Colorado, 2003-5.-Continued

[MCL, maximum contaminant level; SMCL, secondary maximum contaminant level; HBSL, health-based screening level; AMCL, alternative maximum contaminant level; mg/L, milligrams per liter; $\mu \mathrm{S} / \mathrm{cm}$, microsiemens per centimeter; $\mathrm{FNU}$, formazin nephelometric units; ${ }^{\circ} \mathrm{C}$, degrees Celsius; $\mu \mathrm{g} / \mathrm{L}$, micrograms per liter; $\delta \mathrm{D}$, delta deuterium; $\delta^{18} \mathrm{O}$, delta oxygen- $18 ; \delta^{13} \mathrm{C}$, delta carbon- $13 ; \%$, per mil;

pCi/L, picocuries per liter; $\mathrm{Ca}$, calcium; $\mathrm{Mg}$, magnesium; $\mathrm{HCO}_{3}$, bicarbonate; $\mathrm{Na}$, sodium; $\mathrm{Cl}$, chloride; $\mathrm{Br}$, bromide; $\mathrm{CaCO}_{3}$, calcium carbonate; $\mathrm{N}$, nitrogen; $\mathrm{P}$, phosphorus; min., minimum; max., maximum; na, no standard or not applicable; \%, percent; $<$, less than; --, not measured or not determined; n, number of samples; =, equals; E, estimated]

\begin{tabular}{|c|c|c|c|c|c|c|c|c|c|c|c|c|c|}
\hline \multirow{3}{*}{ Constituent } & \multirow{3}{*}{ Units } & \multicolumn{12}{|c|}{ Bedrock aquifers } \\
\hline & & \multicolumn{3}{|c|}{$\begin{array}{c}\text { Dawson aquifer } \\
\text { ( } \mathrm{n}=\mathbf{3 0} \text { unless otherwise noted) }\end{array}$} & \multicolumn{3}{|c|}{$\begin{array}{c}\text { Denver aquifer } \\
\text { ( } \mathrm{n}=10 \text { unless otherwise noted) }\end{array}$} & \multicolumn{3}{|c|}{$\begin{array}{c}\text { Arapahoe aquifer } \\
\text { ( } \mathrm{n}=29 \text { unless otherwise noted) }\end{array}$} & \multicolumn{3}{|c|}{$\begin{array}{c}\text { Laramie-Fox Hills aquifer } \\
\text { ( } \mathrm{n}=10 \text { unless otherwise noted) }\end{array}$} \\
\hline & & Median & $\begin{array}{c}\text { Range } \\
\text { (min.-max.) }\end{array}$ & $\begin{array}{c}\text { Exceed- } \\
\text { ances } \\
(\%)^{1}\end{array}$ & Median & $\begin{array}{c}\text { Range } \\
\text { (min.-max.) }\end{array}$ & $\begin{array}{c}\text { Exceed- } \\
\text { ances } \\
(\%)^{1}\end{array}$ & Median & $\begin{array}{c}\text { Range } \\
\text { (min.-max.) }\end{array}$ & $\begin{array}{c}\text { Exceed- } \\
\text { ances } \\
(\%)^{1}\end{array}$ & Median & $\begin{array}{c}\text { Range } \\
\text { (min.-max.) }\end{array}$ & $\begin{array}{c}\text { Exceed- } \\
\text { ances } \\
(\%)^{1}\end{array}$ \\
\hline Well depth & feet & 384 & $190-790$ & na & 669 & $441-1,150$ & na & 501 & $130-2,149$ & na & 858 & $515-1,450$ & na \\
\hline $\begin{array}{l}\text { Screened interval } \\
\text { length }\end{array}$ & feet & 110 & $40-120$ & na & $70(n=6)$ & $40-300$ & na & 102 & $20-460$ & na & $127.5(\mathrm{n}=8)$ & $80-205$ & na \\
\hline Dissolved oxygen & $\mathrm{mg} / \mathrm{L}$ & 3.8 & M-9.4 & na & 0.3 & $0-1.0$ & na & 0.1 & $0-9.2$ & na & 0.1 & $0-1.3$ & na \\
\hline $\mathrm{pH}$ & $\begin{array}{l}\text { standard } \\
\text { units }\end{array}$ & 7.0 & $6.2-7.9$ & 13 & 8.2 & $7.5-9.3$ & 30 & $8.2(n=28)$ & $6.9-9.4$ & 21 & 8.8 & $7.3-9.4$ & 80 \\
\hline $\begin{array}{l}\text { Specific conduc- } \\
\text { tance }\end{array}$ & $\mu \mathrm{S} / \mathrm{cm}$ & 211 & $78-934$ & na & 330 & $212-706$ & na & 497 & $172-2,640$ & na & 758 & $167-1,230$ & na \\
\hline Temperature & ${ }^{\circ} \mathrm{C}$ & 11.7 & $8.3-16.5$ & na & 15.7 & $12.0-21.0$ & na & 16.5 & $12.3-30.1$ & na & 17.2 & $14.0-22.1$ & na \\
\hline Turbidity & FNU & $0.2(\mathrm{n}=26)$ & $0.1-15$ & na & 0.6 & $0.2-3.9$ & na & $0.3(\mathrm{n}=27)$ & $0.1-14$ & na & 1.1 & $0.1-4.5$ & na \\
\hline $\begin{array}{l}\text { Total dissolved } \\
\text { solids }\end{array}$ & $\mathrm{mg} / \mathrm{L}$ & 151 & $81-610$ & 7 & 207 & $148-459$ & 0 & 314 & $106-1,180$ & 34 & 425 & $102-746$ & 40 \\
\hline Calcium & $\mathrm{mg} / \mathrm{L}$ & 23.6 & $6.1-146$ & na & 19.6 & $1.4-43.9$ & na & 14.3 & 1.4-199 & na & 1.6 & $0.7-20.8$ & na \\
\hline Magnesium & $\mathrm{mg} / \mathrm{L}$ & 2.5 & $0.3-18.8$ & na & 1.5 & $0.2-5.3$ & na & 1.3 & $0.03-44.1$ & na & 0.3 & $0.1-2.7$ & na \\
\hline Potassium & $\mathrm{mg} / \mathrm{L}$ & 2.43 & $0.72-6.90$ & na & 1.96 & $0.53-4.42$ & na & 1.91 & $0.30-12.2$ & na & 1.03 & $0.30-5.50$ & na \\
\hline Sodium & $\mathrm{mg} / \mathrm{L}$ & 11.9 & $6.0-50.3$ & na & 57.0 & $17.7-151$ & na & 95.9 & $4.1-349$ & na & 173 & $8.3-307$ & na \\
\hline Alkalinity & $\begin{array}{c}\mathrm{mg} / \mathrm{L} \text { as } \\
\mathrm{CaCO}_{3}\end{array}$ & $76(n=28)$ & $31-239$ & na & 133 & $66-214$ & na & 143 & $62-427$ & na & 271 & $72-539$ & na \\
\hline Bicarbonate & $\mathrm{mg} / \mathrm{L}$ & $92(\mathrm{n}=28)$ & $38-290$ & na & 161 & $80-255$ & na & 171 & $76-516$ & na & $318(n=9)$ & $95-653$ & na \\
\hline Bromide & $\mathrm{mg} / \mathrm{L}$ & 0.06 & $0.01-0.35$ & na & 0.08 & $0.04-0.24$ & na & 0.06 & $0.02-1.39$ & na & 0.22 & $0.01-0.81$ & na \\
\hline Chloride & $\mathrm{mg} / \mathrm{L}$ & 2.40 & $1.13-91.6$ & 0 & 2.45 & $1.51-10.1$ & 0 & 4.38 & $<0.20-231$ & 0 & 13.3 & $0.57-79.3$ & 0 \\
\hline Fluoride & $\mathrm{mg} / \mathrm{L}$ & 0.47 & $0.09-1.36$ & 0,0 & 1.13 & $0.51-2.29$ & 10,0 & 1.47 & $0.44-3.62$ & 24,0 & 1.15 & $0.47-3.81$ & 20,0 \\
\hline Silica & $\mathrm{mg} / \mathrm{L}$ & 36.4 & $11.0-54.9$ & na & 13.3 & $10.3-19.4$ & na & 11.6 & $8.3-34.7$ & na & 11.3 & $10.0-13.5$ & na \\
\hline Sulfate & $\mathrm{mg} / \mathrm{L}$ & 16.0 & $2.57-261$ & 3 & 25.4 & $10.2-124$ & 0 & 35.8 & $<0.90-655$ & 24 & 1.1 & $<0.18-426$ & 20 \\
\hline $\mathrm{Na} / \mathrm{Cl}$ & molar ratio & 7.4 & $0.5-33$ & na & 25 & $8.3-65$ & na & 23 & $2.3-101$ & na & 18 & $6.0-54$ & na \\
\hline$(\mathrm{Ca}+\mathrm{Mg}) / \mathrm{HCO}_{3}$ & molar ratio & $0.48(n=28)$ & $0.11-2.8$ & na & 0.21 & $0.02-0.55$ & na & 0.14 & $0.01-2.4$ & na & $0.01(n=9)$ & $0.00-0.34$ & na \\
\hline $\mathrm{Na} /(\mathrm{Ca}+\mathrm{Mg})$ & molar ratio & 0.73 & $0.16-8.3$ & na & 4.5 & $0.80-63.7$ & na & 11 & $0.20-107$ & na & 153 & $0.61-239$ & na \\
\hline
\end{tabular}


Table 5. Summary statistics for well completion information, physicochemical properties, and selected geochemical constituents for groundwater samples from the Denver Basin aquifer system, Colorado, 2003-5.-Continued

[MCL, maximum contaminant level; SMCL, secondary maximum contaminant level; HBSL, health-based screening level; AMCL, alternative maximum contaminant level; mg/L, milligrams per liter; $\mu \mathrm{S} / \mathrm{cm}$, microsiemens per centimeter; FNU, formazin nephelometric units; ${ }^{\circ} \mathrm{C}$, degrees Celsius; $\mu \mathrm{g} / \mathrm{L}$, micrograms per liter; $\delta \mathrm{D}$, delta deuterium; $\delta^{18} \mathrm{O}$, delta oxygen- $18 ; \delta^{13} \mathrm{C}$, delta carbon-13; $\%$, per mil; $\mathrm{pCi} / \mathrm{L}$, picocuries per liter; $\mathrm{Ca}$, calcium; $\mathrm{Mg}$, magnesium; $\mathrm{HCO}$, bicarbonate; $\mathrm{Na}$, sodium; $\mathrm{Cl}$, chloride; $\mathrm{Br}$, bromide; $\mathrm{CaCO}_{3}$, calcium carbonate; $\mathrm{N}$, nitrogen; $\mathrm{P}$, phosphorus; min., minimum; max., maximum; na, no standard or not applicable; \%, percent; <, less than; --, not measured or not determined; n, number of samples; =, equals; E, estimated]

\begin{tabular}{|c|c|c|c|c|c|c|c|c|c|c|c|c|c|}
\hline \multirow{3}{*}{ Constituent } & \multirow{3}{*}{ Units } & \multicolumn{12}{|c|}{ Bedrock aquifers } \\
\hline & & \multicolumn{3}{|c|}{$\begin{array}{c}\text { Dawson aquifer } \\
\text { ( } \mathrm{n}=\mathbf{3 0} \text { unless otherwise noted) }\end{array}$} & \multicolumn{3}{|c|}{$\begin{array}{c}\text { Denver aquifer } \\
\text { ( } \mathrm{n}=\mathbf{1 0} \text { unless otherwise noted) }\end{array}$} & \multicolumn{3}{|c|}{$\begin{array}{c}\text { Arapahoe aquifer } \\
\text { ( } n=29 \text { unless otherwise noted) }\end{array}$} & \multicolumn{3}{|c|}{$\begin{array}{c}\text { Laramie-Fox Hills aquifer } \\
\text { ( } n=10 \text { unless otherwise noted) }\end{array}$} \\
\hline & & Median & $\begin{array}{c}\text { Range } \\
\text { (min.-max.) }\end{array}$ & $\begin{array}{c}\text { Exceed- } \\
\text { ances } \\
(\%)^{1} \\
\end{array}$ & Median & $\begin{array}{c}\text { Range } \\
\text { (min.-max.) }\end{array}$ & $\begin{array}{c}\text { Exceed- } \\
\text { ances } \\
(\%)^{1} \\
\end{array}$ & Median & $\begin{array}{c}\text { Range } \\
\text { (min.-max.) }\end{array}$ & $\begin{array}{c}\text { Exceed- } \\
\text { ances } \\
(\%)^{1} \\
\end{array}$ & Median & $\begin{array}{c}\text { Range } \\
\text { (min.-max.) }\end{array}$ & $\begin{array}{c}\text { Exceed- } \\
\text { ances } \\
(\%)^{1}\end{array}$ \\
\hline $\mathrm{Cl} / \mathrm{Br}$ & molar ratio & 42 & $22-262$ & na & 43 & $13-106$ & na & 55 & $38-189$ & na & 81 & $33-107$ & na \\
\hline Ammonia & $\mathrm{mg} / \mathrm{L}$ as $\mathrm{N}$ & $<0.04$ & $<0.04-0.65$ & na & 0.11 & $0.05-0.50$ & na & 0.28 & $<0.04-1.28$ & na & 0.53 & $<0.04-0.90$ & na \\
\hline Nitrate plus nitrite & $\mathrm{mg} / \mathrm{L}$ as $\mathrm{N}$ & 0.25 & $<0.06-5.79$ & na & $<0.06$ & $\begin{array}{l}<0.06- \\
<0.06\end{array}$ & na & $<0.06$ & $<0.06-15.9$ & na & $<0.06$ & $<0.06-<0.06$ & na \\
\hline Nitrate & $\mathrm{mg} / \mathrm{L}$ as $\mathrm{N}$ & 0.25 & $\begin{array}{c}<0.060- \\
5.79\end{array}$ & 0 & $<0.06$ & $\begin{array}{l}<0.054 \\
<0.060\end{array}$ & 0 & $<0.06(\mathrm{n}=28)$ & $\begin{array}{c}<0.060- \\
15.9\end{array}$ & 3 & $<0.06$ & $\begin{array}{l}<0.060- \\
<0.060\end{array}$ & 0 \\
\hline Nitrite & $\mathrm{mg} / \mathrm{L}$ as $\mathrm{N}$ & $<0.008$ & $\begin{array}{c}<0.008- \\
0.092\end{array}$ & 0 & $<0.008$ & $\begin{array}{c}<0.008- \\
0.020\end{array}$ & 0 & $<0.008$ & $\begin{array}{c}<0.008- \\
0.535\end{array}$ & 0 & $<0.008$ & $\begin{array}{l}<0.008- \\
<0.008\end{array}$ & 0 \\
\hline Organic nitrogen & $\mathrm{mg} / \mathrm{L}$ & $<0.01$ & $<0.01-0.12$ & na & $\begin{array}{l}<0.002 \\
(\mathrm{n}=8)\end{array}$ & $\begin{array}{l}<0.002- \\
<0.04\end{array}$ & na & $<0.01(\mathrm{n}=23)$ & $\begin{array}{l}<0.01- \\
\text { E0.64 }\end{array}$ & na & $<0.01$ & $<0.01-<0.13$ & na \\
\hline Orthophosphate & $\mathrm{mg} / \mathrm{L}$ as $\mathrm{P}$ & 0.016 & $\begin{array}{c}<0.006- \\
0.340\end{array}$ & na & E0.005 & $\begin{array}{c}<0.006- \\
0.080\end{array}$ & na & $<0.006$ & $\begin{array}{c}<0.006- \\
0.109\end{array}$ & na & 0.054 & $<0.006-0.197$ & na \\
\hline $\begin{array}{l}\text { Dissolved organic } \\
\text { carbon }\end{array}$ & $\mathrm{mg} / \mathrm{L}$ & 0.55 & $<0.33-3.24$ & na & 0.53 & $<0.33-1.09$ & na & 0.58 & $<0.33-4.39$ & na & 0.53 & $<0.33-0.96$ & na \\
\hline$\delta^{18} \mathrm{O}$ & per mil (\%o) & $\begin{array}{l}-14.10 \\
(\mathrm{n}=26)\end{array}$ & $\begin{array}{l}-15.52 \text { to } \\
-10.30\end{array}$ & na & $\begin{array}{l}-13.88 \\
(\mathrm{n}=9)\end{array}$ & $\begin{array}{l}-14.38 \text { to } \\
-11.04\end{array}$ & na & $-13.83(n=26)$ & $\begin{array}{l}-15.06 \text { to } \\
-10.19\end{array}$ & na & -12.51 & $\begin{array}{l}-14.95 \text { to } \\
-9.61\end{array}$ & na \\
\hline$\delta \mathrm{D}$ & per mil $(\%)$ & $-107(n=26)$ & $\begin{array}{l}-117 \text { to } \\
-78.8\end{array}$ & na & $-104(n=9)$ & $\begin{array}{l}-109 \text { to } \\
-83.7\end{array}$ & na & $-102(\mathrm{n}=26)$ & $\begin{array}{l}-113 \text { to } \\
-75.1\end{array}$ & na & -90.1 & -114 to -71.3 & na \\
\hline$\delta^{13} \mathrm{C}$ & per mil (\%o) & $-13.41(n=9)$ & $\begin{array}{l}-18.98 \text { to } \\
-9.66\end{array}$ & na & $\begin{array}{l}-10.88 \\
(\mathrm{n}=8)\end{array}$ & $\begin{array}{l}-13.07 \text { to } \\
-5.92\end{array}$ & na & $-10.37(n=12)$ & $\begin{array}{l}-13.82 \text { to } \\
-5.29\end{array}$ & na & -10.73 & $\begin{array}{l}-19.06 \text { to } \\
-4.42\end{array}$ & na \\
\hline Aluminum & $\mu \mathrm{g} / \mathrm{L}$ & $<1.6$ & $<1.6-2.5$ & 0 & $<1.6$ & $<1.6-2.0$ & 0 & 1.4 & $<1.6-7.6$ & 0 & 2.3 & $<1.6-5.3$ & 0 \\
\hline Barium & $\mu \mathrm{g} / \mathrm{L}$ & 53.1 & $6.7-318$ & 0 & 58.8 & $12.1-127$ & 0 & 35.4 & $1.53-163$ & 0 & 17.5 & $3.29-51.1$ & 0 \\
\hline Beryllium & $\mu \mathrm{g} / \mathrm{L}$ & 0 & $\begin{array}{c}<0.060- \\
0.432\end{array}$ & 0 & $<0.060$ & $\begin{array}{c}<0.060- \\
0.126\end{array}$ & 0 & $<0.060$ & $\begin{array}{c}<0.060- \\
0.265\end{array}$ & 0 & $<0.060$ & $<0.060-0.095$ & 0 \\
\hline Cadmium & $\mu \mathrm{g} / \mathrm{L}$ & $<0.040$ & $\begin{array}{l}<0.040- \\
\text { E0.031 }\end{array}$ & 0 & $<0.040$ & $<0.040-0.1$ & 0 & $<0.040$ & $\begin{array}{l}<0.040- \\
\text { E0.037 }\end{array}$ & 0 & $<0.040$ & $\begin{array}{l}<0.040- \\
\text { E0.030 }\end{array}$ & 0 \\
\hline Chromium & $\mu \mathrm{g} / \mathrm{L}$ & $<0.8$ & $<0.8-1.1$ & 0 & 0.05 & $<0.04-0.18$ & 0 & $<0.8$ & $<0.8-\mathrm{E} 0.4$ & 0 & 0.04 & E0.03-0.13 & 0 \\
\hline Cobalt & $\mu \mathrm{g} / \mathrm{L}$ & 0.083 & $\begin{array}{c}\text { E0.01- } \\
0.585\end{array}$ & na & 0.015 & $\begin{array}{c}<0.040- \\
0.066\end{array}$ & na & 0.033 & $\begin{array}{c}<0.014- \\
0.35\end{array}$ & na & $<0.040$ & $\begin{array}{l}<0.040- \\
\text { E0.024 }\end{array}$ & na \\
\hline
\end{tabular}


Table 5. Summary statistics for well completion information, physicochemical properties, and selected geochemical constituents for groundwater samples from the Denver Basin aquifer system, Colorado, 2003-5.-Continued

[MCL, maximum contaminant level; SMCL, secondary maximum contaminant level; HBSL, health-based screening level; AMCL, alternative maximum contaminant level; mg/L, milligrams per liter; $\mu \mathrm{S} / \mathrm{cm}$, microsiemens per centimeter; $\mathrm{FNU}$, formazin nephelometric units; ${ }^{\circ} \mathrm{C}$, degrees Celsius; $\mu \mathrm{g} / \mathrm{L}$, micrograms per liter; $\delta \mathrm{D}$, delta deuterium; $\delta^{18} \mathrm{O}$, delta oxygen- $18 ; \delta^{13} \mathrm{C}$, delta carbon- $13 ; \%$, per mil;

$\mathrm{pCi} / \mathrm{L}$, picocuries per liter; $\mathrm{Ca}$, calcium; $\mathrm{Mg}$, magnesium; $\mathrm{HCO}_{3}$, bicarbonate; $\mathrm{Na}$, sodium; $\mathrm{Cl}$, chloride; $\mathrm{Br}$, bromide; $\mathrm{CaCO}_{3}$, calcium carbonate; $\mathrm{N}$, nitrogen; $\mathrm{P}$, phosphorus; min., minimum; max., maximum; na, no standard or not applicable; \%, percent; $<$, less than; --, not measured or not determined; n, number of samples; =, equals; E, estimated]

\begin{tabular}{|c|c|c|c|c|c|c|c|c|c|c|c|c|c|}
\hline \multirow{3}{*}{ Constituent } & \multirow{3}{*}{ Units } & \multicolumn{12}{|c|}{ Bedrock aquifers } \\
\hline & & \multicolumn{3}{|c|}{$\begin{array}{c}\text { Dawson aquifer } \\
\text { ( } \mathrm{n}=30 \text { unless otherwise noted) }\end{array}$} & \multicolumn{3}{|c|}{$\begin{array}{c}\text { Denver aquifer } \\
\text { ( } \mathrm{n}=10 \text { unless otherwise noted) }\end{array}$} & \multicolumn{3}{|c|}{$\begin{array}{c}\text { Arapahoe aquifer } \\
\text { ( } \mathrm{n}=29 \text { unless otherwise noted) }\end{array}$} & \multicolumn{3}{|c|}{$\begin{array}{c}\text { Laramie-Fox Hills aquifer } \\
\text { ( } n=10 \text { unless otherwise noted) }\end{array}$} \\
\hline & & Median & $\begin{array}{c}\text { Range } \\
\text { (min.-max.) }\end{array}$ & $\begin{array}{c}\text { Exceed- } \\
\text { ances } \\
(\%)^{1}\end{array}$ & Median & $\begin{array}{c}\text { Range } \\
\text { (min.-max.) }\end{array}$ & $\begin{array}{c}\text { Exceed- } \\
\text { ances } \\
(\%)^{1}\end{array}$ & Median & $\begin{array}{c}\text { Range } \\
\text { (min.-max.) }\end{array}$ & $\begin{array}{c}\text { Exceed- } \\
\text { ances } \\
(\%)^{1}\end{array}$ & Median & $\begin{array}{c}\text { Range } \\
\text { (min.-max.) }\end{array}$ & $\begin{array}{c}\text { Exceed- } \\
\text { ances } \\
(\%)^{1}\end{array}$ \\
\hline Copper & $\mu \mathrm{g} / \mathrm{L}$ & 4.2 & $<0.4-40.3$ & 0 & 0.4 & $<0.4-10$ & 0 & 0.4 & $<0.4-13.9$ & 0 & 0.1 & $<0.4-1.9$ & 0 \\
\hline Iron & $\mu \mathrm{g} / \mathrm{L}$ & 2.1 & $<6.0-595$ & 10 & 35 & $<6.0-555$ & 10 & 18 & $<6.0-4,100$ & 17 & 18 & $<6.0-2,360$ & 20 \\
\hline Lead & $\mu \mathrm{g} / \mathrm{L}$ & 0.200 & $\begin{array}{c}<0.080- \\
0.985\end{array}$ & 0 & 0.103 & $\begin{array}{c}<0.080- \\
0.620\end{array}$ & 0 & 0.048 & $\begin{array}{c}<0.080- \\
2.26\end{array}$ & na & 0.030 & $<0.080-1.13$ & 0 \\
\hline Lithium & $\mu \mathrm{g} / \mathrm{L}$ & 13 & $3.44-122$ & na & 10 & $1.67-22.9$ & na & 19 & $4.29-86.1$ & na & 18 & $6.62-41.3$ & na \\
\hline Manganese & $\mu \mathrm{g} / \mathrm{L}$ & 4.05 & $<0.20-508$ & 23,7 & 18.8 & $5.24-108$ & 20,0 & 12.6 & $0.23-868$ & 24,7 & 4.98 & $2.42-46.9$ & 0,0 \\
\hline Molybdenum & $\mu \mathrm{g} / \mathrm{L}$ & 0.95 & $\begin{array}{l}<0.400- \\
4.53\end{array}$ & na & 2.13 & $1.29-3.96$ & na & 1.77 & $<0.400-12$ & na & 1.12 & E0.326-3.3 & na \\
\hline Nickel & $\mu \mathrm{g} / \mathrm{L}$ & 0.31 & $<0.06-4.24$ & na & 0.14 & $<0.06-0.99$ & na & 0.41 & $0.06-4.87$ & na & 0.09 & $<0.06-0.27$ & na \\
\hline Silver & $\mu \mathrm{g} / \mathrm{L}$ & $<0.200$ & $\begin{array}{l}<0.200- \\
<0.200\end{array}$ & 0 & $<0.200$ & $\begin{array}{l}<0.200- \\
<0.200\end{array}$ & 0 & $<0.200$ & $\begin{array}{l}<0.200- \\
<0.200\end{array}$ & 0 & $<0.200$ & $\begin{array}{l}<0.200 \\
<0.200\end{array}$ & 0 \\
\hline Strontium & $\mu \mathrm{g} / \mathrm{L}$ & 248 & $63.1-1,150$ & 0 & 177 & $22-446$ & 0 & 180 & $12.9-1,480$ & 0 & 43 & $9.01-177$ & 0 \\
\hline Thallium & $\mu \mathrm{g} / \mathrm{L}$ & $<0.040$ & $\begin{array}{l}<0.040- \\
\text { E0.028 }\end{array}$ & 0 & $<0.040$ & $\begin{array}{l}<0.040- \\
<0.040\end{array}$ & 0 & $<0.040$ & $\begin{array}{c}<0.040- \\
0.09\end{array}$ & 0 & $<0.040$ & $\begin{array}{l}<0.040- \\
<0.040\end{array}$ & 0 \\
\hline Vanadium & $\mu \mathrm{g} / \mathrm{L}$ & 0.15 & $<0.10-9.3$ & na & $<0.10$ & $<0.10-1.2$ & na & 0.20 & $<0.10-2.0$ & na & $<0.10$ & $<0.10-0.16$ & na \\
\hline Zinc & $\mu \mathrm{g} / \mathrm{L}$ & 14.9 & $0.9-1,070$ & 0,0 & 3.7 & E0.4-112 & 0,0 & 6.2 & $<0.6-560$ & 0,0 & 6.1 & $<0.6-193$ & 0,0 \\
\hline Antimony & $\mu \mathrm{g} / \mathrm{L}$ & $<0.200$ & $\begin{array}{l}<0.200- \\
\text { E0.135 }\end{array}$ & 0 & $<0.200$ & $\begin{array}{l}<0.200 \\
<0.200\end{array}$ & 0 & $<0.200$ & $\begin{array}{l}<0.200- \\
\text { E0.170 }\end{array}$ & 0 & $<0.200$ & $\begin{array}{l}<0.200 \\
<0.200\end{array}$ & 0 \\
\hline Boron & $\mu \mathrm{g} / \mathrm{L}$ & 26 & $10-66$ & na & 57 & $44-73$ & na & 58 & $12-438$ & na & 174 & $15-643$ & na \\
\hline Selenium & $\mu \mathrm{g} / \mathrm{L}$ & 0.8 & $<0.4-18.6$ & 0 & $<0.08$ & $<0.08-10.9$ & 0 & $<0.4$ & $<0.08-118$ & 3 & $<0.08$ & $<0.08-0.23$ & 0 \\
\hline Radon & $\mathrm{pCi} / \mathrm{L}$ & 1,545 & $300-25,500$ & 97,7 & -- & -- & -- & 460 & $70-1,470$ & 90,0 & -- & -- & -- \\
\hline Uranium & $\mu \mathrm{g} / \mathrm{L}$ & 0.81 & $\begin{array}{c}<0.040- \\
20.3\end{array}$ & 0 & 0.040 & $\begin{array}{c}<0.040- \\
1.78\end{array}$ & 0 & 0.023 & $\begin{array}{c}<0.040- \\
7.31\end{array}$ & 0 & 0.040 & $\begin{array}{l}<0.040- \\
\text { E0.030 }\end{array}$ & 0 \\
\hline Arsenic & $\mu \mathrm{g} / \mathrm{L}$ & 1.7 & $<0.2-10.7$ & 3 & $<0.12$ & $<0.12-0.42$ & 0 & $<0.2$ & $<0.2-6.7$ & 0 & $<0.12$ & $<0.12-0.15$ & 0 \\
\hline
\end{tabular}

${ }^{1}$ Exceedances of drinking-water and health-based benchmarks.

${ }^{2}$ The radon MCL and alternative MCL are proposed levels (U.S. Environmental Protection Agency, 2013) 


\section{Quality Control}

Quality-control (QC) samples were collected and analyzed to assess variability of environmental samples and to evaluate bias for field collection procedures and equipment cleaning between collection of samples; QC samples include field QC samples in the form of blank, replicate, and matrixspike recovery samples and also laboratory QC samples. About 10 percent of all samples collected (environmental and QC combined) were blanks, 10 percent were replicates, and 10 percent were matrix spikes. QC samples were collected as described in the National Field Manual (U.S. Geological Survey, variously dated) and analyzed by the same laboratories and methods as the environmental samples.

Blank samples test for bias from the introduction of contaminants to environmental samples from sample collection, from cleaning protocols, or during sampling and preservation. Field blanks were collected following environmental sample collection and subsequent cleaning of equipment and were processed the same as environmental samples. Equipment and source-solution blanks were also collected during the study period by using high-purity organic-free or inorganic-free water that was prepared and tested by the NWQL. Equipment blanks were collected to evaluate if the equipment or sample collection processes, including decontamination procedures, might bias the data. Source-solution blanks were collected to verify that the blank water used for the field blanks was not a source of detectable concentrations of constituents. Source-solution blanks were collected at the sampling site by pouring blank water (source solution) into sample containers that were stored, shipped, and analyzed in the same manner as the field-blank and environmental samples. Blank samples were analyzed for some combination of major ions, nutrients, trace elements, pesticides, and VOCs; equipment and source-solution blanks were not analyzed for pesticide compounds.

Several constituents were detected in field blanks (table 6), in equipment blanks, or in source-solution blanks. Detected concentrations of major ions and trace elements in these blank samples were generally negligible in comparison with concentrations measured in environmental samples, although several trace elements that were not of primary interpretive interest for the current study (such as aluminum, cadmium, chromium, and cobalt) were detected in some blank samples at similar concentrations to those in environmental samples. DOC was detected in 7 (47 percent) of the field blanks, which might result from insufficient removal of methanol from sampling equipment during cleaning.

Detection of organic contaminants in a groundwater sample can be used as an indicator of a component of modern groundwater because older water is generally free of organic contaminants. Because of the importance of such an indication on the interpretation of environmental data, detections of organic compounds in blank and environmental samples were evaluated to limit effects of sample bias or potential external sample contamination. No pesticides were detected in blank samples. One VOC, chloroform, was detected in one source-solution blank, at an estimated (E) concentration of $0.066 \mu \mathrm{g} / \mathrm{L}$. Thirteen VOC compounds were detected in a single field blank, most of which were not detected in other blank samples, in the paired environmental sample, or in other environmental samples collected during the study. It was determined that results for this field blank were affected by contamination and thus not representative of potential sources of contamination to groundwater samples. As a result, data for this field blank are not considered further in this report and have been assigned a remark code ("V"), indicating that the measured values are affected by contamination. For the remaining field blanks, acetone was detected in 2 (18 percent) field blanks but was not detected in any environmental samples. Carbon disulfide and chloroform were detected in 2 (18 percent) and 3 (27 percent) of the remaining field blanks, respectively, and in several environmental samples. A national review of field QC samples for the NAWQA Program between 1996 and 2008 indicated that data for some VOCs have potential contamination bias associated with field protocols (Bender and others, 2011). As a result, detections in environmental samples for VOCs were evaluated at common assessment levels as determined by Bender and others (2011), at which there is 90-percent confidence that this amount of contamination would be exceeded in no more than 10 percent of all samples. VOC detections less than these common assessment levels were treated as nondetections at a concentration less than the assessment level. Bender and others (2011) evaluated QC data independently for different well types, that is, monitoring wells relative to domestic- and public-supply wells. For comparative purposes between well types for the current study, where assessment levels differed for well types, the higher assessment level was applied consistently. Based on this approach, the following compounds and data were censored: 4 environmental samples for toluene at an assessment level of $0.08 \mu \mathrm{g} / \mathrm{L}$ and 13 environmental samples for chloroform at an assessment level of $0.07 \mu \mathrm{g} / \mathrm{L}$.

Factors such as well construction and casing materials have the potential to affect water quality and have been investigated as sources of error in water-quality measurements (Llopis, 1991; Pohlmann and Alduino, 1992). For example, tetrahydrofuran was not detected in any samples from the water-table wells but was detected in eight (13 percent) samples from the bedrock aquifers. Tetrahydrofuran is used primarily as a solvent for polymers and resins, including food packaging adhesives; specific sources in the Denver Basin have not been documented. Tetrahydrofuran is also a major constituent of PVC primer and adhesive (Sosebee and others, 1983), and at least 7 of the 8 bedrock-aquifer wells from which groundwater samples had tetrahydrofuran detections have PVC screens (Colorado Division of Water Resources, 2012). The high proportion of PVC well materials used in wells with tetrahydrofuran detections cannot be excluded as a potential source of VOC contamination. Where detected in bedrock-aquifer samples, tetrahydrofuran concentrations might result from well-construction materials 
Table 6. Constituents detected in groundwater field-blank samples, Denver Basin aquifer system, Colorado, 2003-5.

$[<$, less than; E, estimated value]

\begin{tabular}{|c|c|c|c|c|}
\hline Detected constituent & $\begin{array}{c}\text { Number of } \\
\text { detections } \\
\text { (number of } \\
\text { blank samples) }\end{array}$ & $\begin{array}{c}\text { Median } \\
\text { concentration } \\
\text { in blank samples }\end{array}$ & $\begin{array}{c}\text { Maximum } \\
\text { concentration } \\
\text { in blank samples }\end{array}$ & $\begin{array}{c}\text { Minimum } \\
\text { concentration in } \\
\text { environmental samples }\end{array}$ \\
\hline \multicolumn{5}{|c|}{ Major ions, milligrams per liter } \\
\hline Calcium & $11(11)$ & 0.12 & 0.58 & 0.73 \\
\hline Magnesium & $5(11)$ & $<0.008$ & 0.008 & 0.03 \\
\hline Sodium & $6(11)$ & $<0.2$ & 0.6 & 4.1 \\
\hline Bromide & $1(11)$ & $<0.02$ & E0.01 & E0.01 \\
\hline Chloride & $1(11)$ & $<0.2$ & 5.1 & $<0.20$ \\
\hline Silica & $11(11)$ & 0.045 & 3.32 & 8.3 \\
\hline Sulfate & $2(11)$ & $<0.18$ & 10.6 & $<0.18$ \\
\hline \multicolumn{5}{|c|}{ Nutrients, milligrams per liter } \\
\hline Total nitrogen, analytically determined & $1(9)$ & $<0.03$ & 0.06 & $<0.03$ \\
\hline \multicolumn{5}{|c|}{ Trace elements, micrograms per liter } \\
\hline Aluminum & $10(15)$ & E1.1 & 48.5 & $<1.6$ \\
\hline Barium & $6(15)$ & $<0.20$ & 0.47 & 1.5 \\
\hline Cadmium & $1(15)$ & $<0.04$ & 0.04 & $<0.04$ \\
\hline Chromium & $4(15)$ & $<0.8$ & 0.23 & $<0.8$ \\
\hline Cobalt & $3(15)$ & $<0.015$ & 0.162 & $<0.040$ \\
\hline Copper & $3(15)$ & $<0.4$ & 0.7 & $<0.4$ \\
\hline Iron & $4(10)$ & $<8.0$ & 10.9 & $<6.0$ \\
\hline Lead & $1(15)$ & $<0.08$ & 0.22 & $<0.08$ \\
\hline Manganese & $4(16)$ & $<0.20$ & 0.68 & $<0.18$ \\
\hline Molybdenum & $1(15)$ & $<0.40$ & 0.35 & $<0.40$ \\
\hline Nickel & $9(15)$ & E0.06 & 0.49 & $<0.06$ \\
\hline Silver & $1(15)$ & $<0.20$ & E0.13 & $<0.20$ \\
\hline Strontium & $7(15)$ & $<0.40$ & 0.72 & 9.01 \\
\hline Zinc & $6(15)$ & $<0.6$ & 3.3 & $<0.6$ \\
\hline Boron & $2(15)$ & $<8$ & 11 & 10 \\
\hline Uranium & $1(15)$ & $<0.04$ & E0.01 & $<0.04$ \\
\hline \multicolumn{5}{|c|}{ Volatile organic compounds, micrograms per liter } \\
\hline Acetone & $2(11)$ & $<6.0$ & E3.7 & $<6.0$ \\
\hline Carbon disulfide & $2(11)$ & $<0.04$ & E0.07 & $<0.04$ \\
\hline Trichloromethane (chloroform) & $3(11)$ & $<0.024$ & E0.058 & $<0.024$ \\
\hline \multicolumn{5}{|c|}{ Other, milligrams per liter } \\
\hline Dissolved organic carbon & $7(15)$ & $<0.33$ & 1.12 & $<0.33$ \\
\hline
\end{tabular}

and, thus, not be indicative of the downward migration of shallow groundwater to the bedrock aquifers. An evaluation of QC data collected for the California Groundwater Ambient Monitoring and Assessment Program determined that because of extrinsic contamination sources such as well-construction materials it was not possible to define a threshold concentration for tetrahydrofuran above which it could be reasonably certain that detections in groundwater samples were not the result of contamination (Fram and others, 2012). As a result, tetrahydrofuran detections for samples from the bedrock aquifers were censored and are not considered further in this report; these data have been assigned a remark code ("V"), indicating that the values are affected by contamination. 
Replicate samples are used to evaluate variability in measurements associated with sample collection protocols, analytical processes, or natural variation. Replicate samples were collected immediately after the associated environmental samples by using the same procedures. The deviation between a replicate sample and an environmental sample is expressed as the relative percent difference (RPD) as

$$
\mathrm{RPD}=\left\{\left|\mathrm{C}_{1}-\mathrm{C}_{2}\right| /\left(\left(\mathrm{C}_{1}+\mathrm{C}_{2}\right) / 2\right)\right\} * 100,
$$

where

$$
\begin{gathered}
\mathrm{C}_{1} \text { is the constituent concentration from the } \\
\text { environmental sample, and } \\
\mathrm{C}_{2} \text { is the constituent concentration, in the same } \\
\text { units, from the replicate sample. }
\end{gathered}
$$

RPD values were calculated for sample pairs only for analytes (environmental and replicate sample pairs) where values for both were detected. Values measured at low concentrations are more likely to yield a large RPD, and as a result, consideration should be given to the magnitude of concentrations when evaluating RPDs. RPDs of 20 percent or less were considered acceptable. For most environmental and replicate sample pairs analyzed for pesticide compounds and VOCs, reported values were less than the applicable detection limit, and thus RPDs were not calculated. Most RPDs were less than 5 percent, indicating excellent reproducibility and an acceptable amount of variability between environmental and replicate samples (table 7). Many of the trace-element environmental and replicate sample pairs with relatively large RPDs had relatively low or estimated concentrations, which might contribute to the large RPDs. For dissolved-gas, agetracer, and isotopic analyses, replicate samples were routinely analyzed by the respective laboratories and were generally within acceptable limits for these analyses. RPDs were not calculated for age tracers, although most CFC analyses were analyzed in replicate. Some CFC replicate analyses had relatively large variability; these differences likely represent variability in the concentrations of CFCs in individual sample bottles. Many of the samples collected for the current study had relatively low CFC concentrations, and the sensitivity of the laboratory method could also contribute to the level of variability observed in the data.

Field spikes are used to assess bias and variability from groundwater matrix interference or degradation of organic constituent concentrations during sample processing, storage, and analysis. Field spikes are environmental samples to which a known volume and concentration of analytes is added.
Analytical recoveries of the spiked constituents are expressed as percentages of expected (theoretical) concentrations. Computed field-spike recoveries were compared to theoretical and lab recoveries to evaluate matrix interferences or degradation of organic compounds. Spike recovery (in percent) is computed as follows:

$$
\text { Recovery }=\left(\left(\mathrm{C}_{\text {spiked }}-\mathrm{C}_{\text {unspiked_sample }}\right) / \mathrm{C}_{\text {expected }}\right) * 100 \text {, }
$$

where

$$
\begin{array}{cl}
\mathrm{C}_{\text {spiked }} & \begin{array}{c}
\text { is the concentration measured for the spiked } \\
\text { environmental sample; } \\
\text { is the concentration measured for the } \\
\text { unspiked environmental sample; and } \\
\mathrm{C}_{\text {unspiked_sample }}
\end{array} \\
\mathrm{C}_{\text {expected }} & \begin{array}{c}
\text { is the theoretical concentration in the } \\
\text { spiked environmental sample, based on } \\
\text { spiked concentrations, known volume of } \\
\text { individual spiked compounds, and volume } \\
\text { of spiked environmental sample. }
\end{array}
\end{array}
$$

Eight pesticide and three VOC field spikes were collected and analyzed. Mean percent recoveries were evaluated for compounds with two or more detections in environmental samples (table 8). Spike recoveries were considered acceptable for the current study. One of the field spikes for chloroform was not considered; the associated environmental sample had the highest measured chloroform concentration of the current study $(9.38 \mu \mathrm{g} / \mathrm{L})$, which exceeded the expected spike concentration by an order of magnitude. Analytical recoveries for deethylatrazine were lower than expected and were qualified as estimated values by appending an E remark code to the results in accordance with laboratory reporting conventions used during the study period (Sandstrom and others, 2001).

In addition to field spikes, surrogate compounds are added in the laboratory to environmental samples at the time of analysis. Surrogate compounds generally do not occur in nature and have a range of expected recoveries, usually near 100 percent. Surrogate compounds have similar physical and chemical properties to analytes of interest and are used to assess matrix effects and potential gross-sample processing problems and to verify that analyses are acceptable. Surrogate compounds were evaluated for organic compound analytical schedules. Recoveries ranged from 85 to 128 percent for Denver Basin samples, which were, for the most part, within laboratory QC limits, indicating that analytical instrument performance was satisfactory. 
Table 7. Summary of replicate sample results for quality-control samples, Denver Basin aquifer system, Colorado, $2003-5$.

$[<$, less than; RPD, relative percent difference; $\geq$, greater than or equal to; na, not applicable]

\begin{tabular}{|c|c|c|c|c|c|c|c|}
\hline $\begin{array}{c}\text { Constituent } \\
\text { group }\end{array}$ & $\begin{array}{c}\text { Number } \\
\text { of sets of } \\
\text { environmental } \\
\text { and replicate } \\
\text { sample pairs }\end{array}$ & $\begin{array}{c}\text { Number of } \\
\text { environmental } \\
\text { and replicate } \\
\text { sample pairs } \\
\text { with detected } \\
\text { concentrations }\end{array}$ & $\begin{array}{l}\text { Replicate } \\
\text { pairs with } \\
<5 \text { percent } \\
\text { RPD }\end{array}$ & $\begin{array}{l}\text { Replicate } \\
\text { pairs with } \\
\geq 5 \text { percent } \\
\text { RPD }\end{array}$ & $\begin{array}{c}\text { Mean } \\
\text { RPD } \\
\text { (percent) }\end{array}$ & $\begin{array}{l}\text { Maximum } \\
\text { RPD } \\
\text { (percent) }\end{array}$ & $\begin{array}{l}\text { Constituent(s) with } \\
\geq 5 \text { percent RPD and } \\
\text { (RPD values, percent) }\end{array}$ \\
\hline Major ions & Up to 14 & 126 & 124 & 2 & 0.6 & 16.7 & Bromide $(5.6,16.7)$ \\
\hline Alkalinity & 13 & 13 & 13 & 0 & 0.8 & 2.9 & na \\
\hline Trace elements & Up to 17 & 255 & 207 & 48 & 2.5 & 34.4 & $\begin{array}{l}\text { Aluminum }(5.4,6.7,10.5,25.7,20.0), \\
\text { beryllium }(14.3), \\
\text { cadmium }(8.9,10.0), \\
\text { chromium }(5.6,5.6,7.9), \\
\text { cobalt }(5.1,6.6,11.9), \\
\text { copper }(5.6,6.3,10.0), \\
\text { iron }(5.5,5.8,6.9,9.5,11.0), \\
\text { lead }(5.1,18.5), \\
\text { lithium }(9.1), \\
\text { manganese }(8.3,24.7), \\
\text { nickel }(5.1,5.1,5.2,6.3), \\
\text { silver }(7.1), \\
\text { vanadium }(5.6,10.0,10.0,10.0), \\
\text { zinc }(5.4,6.3,34.4) \\
\text { antimony }(6.1), \\
\text { boron }(7.6,10.0), \\
\text { selenium }(6.3,21.4), \\
\text { uranium }(5.1), \\
\text { arsenic }(5.6,6.1,9.1),\end{array}$ \\
\hline
\end{tabular}

Table 8. Summary of field-spike results for quality-control samples, Denver Basin aquifer system, Colorado, 2003-5.

[n, number of samples; =, equals]

\begin{tabular}{lc}
\hline \multicolumn{1}{c}{ Constituent } & $\begin{array}{c}\text { Percent recovery, mean } \\
\text { (n=3 unless otherwise noted) }\end{array}$ \\
\hline Atrazine & 105 \\
Deethylatrazine & 38 \\
Metolachlor & 110 \\
Prometon & 103 \\
Simazine & 95 \\
Carbon disulfide & 90 \\
Bromodichloromethane & 108 \\
Dichlorodifluoromethane & 95 \\
Dichloromethane & 102 \\
Methyl tert-butyl ether (MTBE) & 97 \\
Tetrachloroethene (PCE) & 100 \\
Trichloromethane (chloroform) & $106(\mathrm{n}=2)$ \\
\hline
\end{tabular}




\section{Quality of Groundwater in the Denver Basin Aquifer System}

This section describes the physical and chemical characteristics of groundwater samples collected from the Denver Basin aquifer system. Special emphasis is placed on understanding the geochemistry of the bedrock aquifers with respect to their vulnerability to naturally occurring and humansourced contaminants.

\section{Major-Ion Chemistry}

The major-ion chemistry of groundwater can provide insights into water-quality concerns, the composition of recharge sources, and mineral-solution reactions that occur along flow paths. A trilinear (Piper) diagram (Piper, 1953) is a useful tool for describing the relative proportion of dissolved cations and anions and for classifying water composition. Groundwater samples from the Denver Basin span a broad range of major-ion compositions (fig. 10). Water-table well samples had variable compositions, with cations proportionally dominated by $\mathrm{Ca}, \mathrm{Na}$, or both and anions dominated by $\mathrm{HCO}_{3}, \mathrm{SO}_{4}$, or both (fig. 10). Samples from urban land-use wells had a higher proportion of Ca relative to $\mathrm{Na}$ and were mostly $\mathrm{Ca}-\mathrm{HCO}_{3}$ or $\mathrm{Ca}-\mathrm{SO}_{4}$ compositions. Samples from agricultural land-use wells were more compositionally variable than those from the urban land-use wells, with a mix of mostly $\mathrm{Ca}-\mathrm{HCO}_{3}$ and $\mathrm{Ca}-\mathrm{SO}_{4}$ compositions. These water-table well sample compositions are similar to those previously reported for groundwater associated with urban and agricultural land uses in the South Platte River alluvial aquifer (Bruce and McMahon, 1998). Previous studies of the alluvial aquifer have noted that less-mineralized water in the upgradient recharge areas is dominated by $\mathrm{Ca}$ and $\mathrm{HCO}_{3}$ ions, whereas $\mathrm{Na}$ and $\mathrm{SO}_{4}$ are more prevalent downgradient (Bruce and McMahon, 1988; Robson, 1989). Consistent with previous studies, median $\mathrm{SO}_{4}$ and $\mathrm{Na}$ concentrations were higher for samples from the agricultural land-use wells relative to those from the urban land-use wells (table 5). The agricultural land-use wells are generally downgradient along regional flow paths from the urban land-use wells, toward the north and east basin margins (Robson, 1987; Paschke, 2011) (fig. 9). This evolution from $\mathrm{HCO}_{3}$ to $\mathrm{SO}_{4}$ as the dominant anion is generally accompanied by an increase in TDS concentrations (Kendall's tau for the relation between TDS and $\mathrm{SO}_{4}$ for alluvial aquifer samples $=0.81$ ). Previous studies have attributed these changes to human effects from fertilizer application and urban wastewater discharge, as well as to interaction with sulfur-bearing rock units (Bruce and McMahon, 1998). Water in the alluvial aquifer is primarily derived from the infiltration of surface water from streams and from irrigation water; dissolvedsolids concentrations in the South Platte River generally increase downstream, which affects the water quality of the alluvial aquifer (Robson, 1989). Additionally, evaporative concentration of irrigation recharge concentrates dissolved salts and minerals in the shallow subsurface. Subsequent leaching of these salts and minerals, as well as leaching of the soils, provides sources of dissolved constituents to the alluvial aquifer (Robson, 1989).

The composition of samples from the bedrock aquifers was also variable, ranging from $\mathrm{Ca}-\mathrm{HCO}_{3}$ to $\mathrm{Na}-\mathrm{SO}_{4}$ compositions (fig. 10). Compositions were dominantly $\mathrm{Ca}-\mathrm{HCO}_{3}$ in the upper bedrock aquifers, with some $\mathrm{Ca}-\mathrm{SO}_{4}$, and evolved to an increasing proportion of $\mathrm{Na}-\mathrm{HCO}_{3}$, with some $\mathrm{Na}-\mathrm{SO}_{4}$, in the deeper bedrock aquifers. This evolution is likely a result of longer residence times and more extensive water-rock interaction, including ion-exchange and redox processes associated with the deeper bedrock aquifers. These results are consistent with those of previous studies of the bedrock aquifers (for example, Robson, 1987).

TDS concentrations provide a general indication of overall water quality. High concentrations of TDS affect the suitability of water for various uses and affect aesthetic properties of drinking water. The SMCL for TDS is 500 $\mathrm{mg} / \mathrm{L}$, which is based on concerns related to aesthetic and (or) corrosive effects (U.S. Environmental Protection Agency, 2011). TDS concentrations for samples from the watertable wells varied appreciably but were generally high, with 63 percent exceeding the SMCL (table 5). Additionally, concentrations of $\mathrm{SO}_{4}$ for about half (48 percent) of the samples from the water-table wells exceeded the SMCL of $250 \mathrm{mg} / \mathrm{L}$ (table 5). Relatively high TDS concentrations in samples from the water-table wells are consistent with the accumulation of salts from irrigation recharge in the soils and unsaturated sediments that overlie the alluvial aquifer; soluble salts subsequently dissolve and are transported to the water table with infiltrating recharge during wet climatic conditions or as a result of irrigation.

TDS concentrations generally decreased with depth (fig. 11), and concentrations for samples from the bedrock aquifers were mostly lower than those from the water-table wells (table 5). Twenty percent of the samples from the bedrock aquifers exceeded the TDS SMCL, and 13 percent exceeded the $\mathrm{SO}_{4} \mathrm{SMCL}$. Correspondingly, most major-ion concentrations, excluding $\mathrm{F}$ and $\mathrm{Na}$, were lower for samples from the bedrock aquifers relative to those from the watertable wells, with mostly lower median concentrations of $\mathrm{Ca}$, magnesium $(\mathrm{Mg})$, potassium $(\mathrm{K})$, chloride $(\mathrm{Cl}), \mathrm{SO}_{4}$, and $\mathrm{HCO}_{3}$ (excluding $\mathrm{HCO}_{3}$ in the Laramie-Fox Hills aquifer, which had the highest $\mathrm{HCO}_{3}$ median concentration) (table 5). Median concentrations of $F$ in samples from the deeper bedrock aquifers (Denver, Arapahoe, and Laramie-Fox Hills aquifers) were higher than those from the water-table wells and the Dawson aquifer, with a correspondingly higher percentage of SMCL exceedances for F (table 5). Elevated F concentrations in samples from the deeper bedrock aquifers are consistent with weathering of silicic igneous and sedimentary rocks; volcanic ash, which is present in the bedrock aquifers (table 1), is generally rich in F (Hem, 1992). 


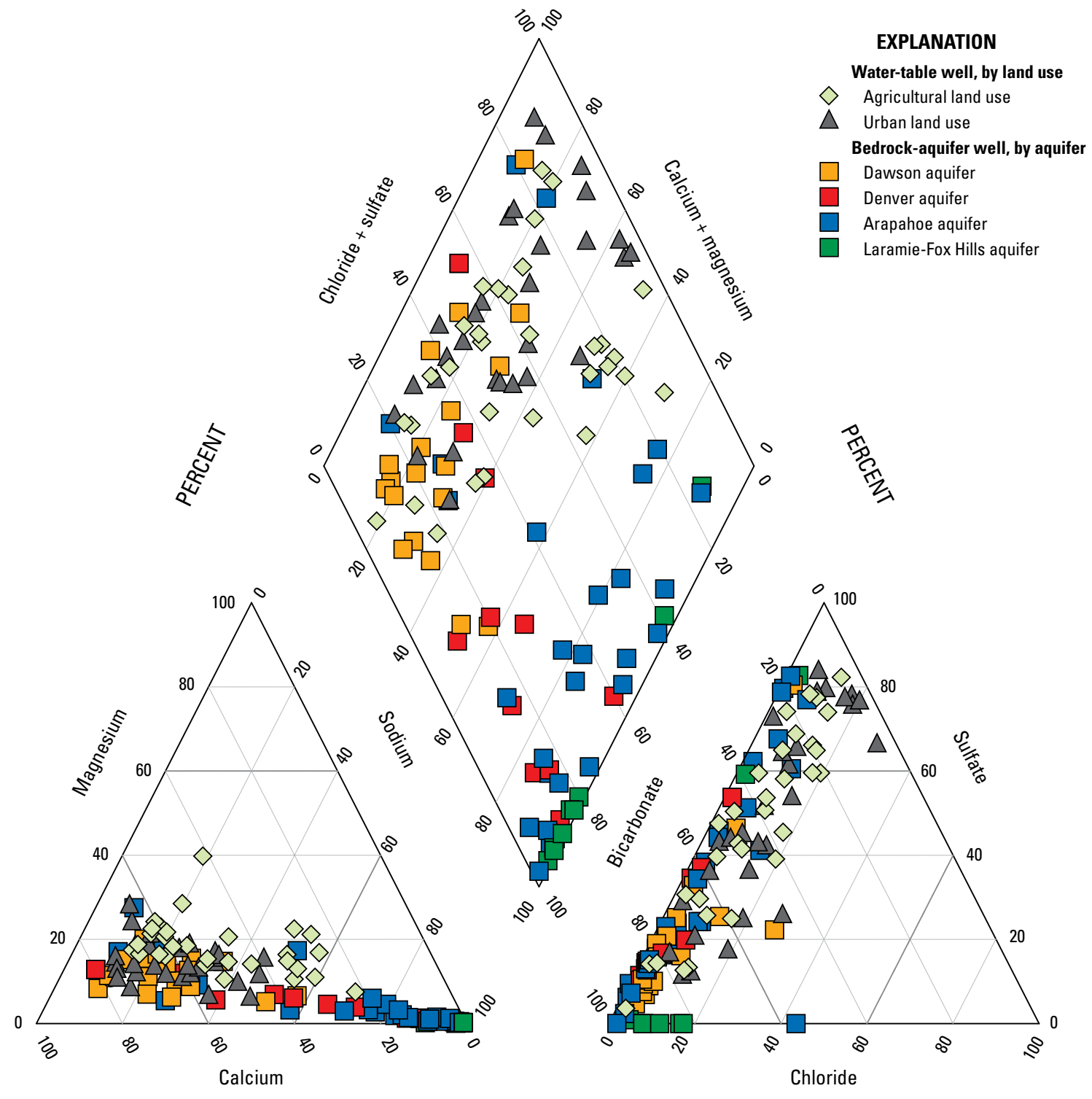

PERCENT

Figure 10. Trilinear diagram showing relations between major cations and anions in groundwater samples, Denver Basin aquifer system, Colorado, 2003-5. 
$\boldsymbol{A}$

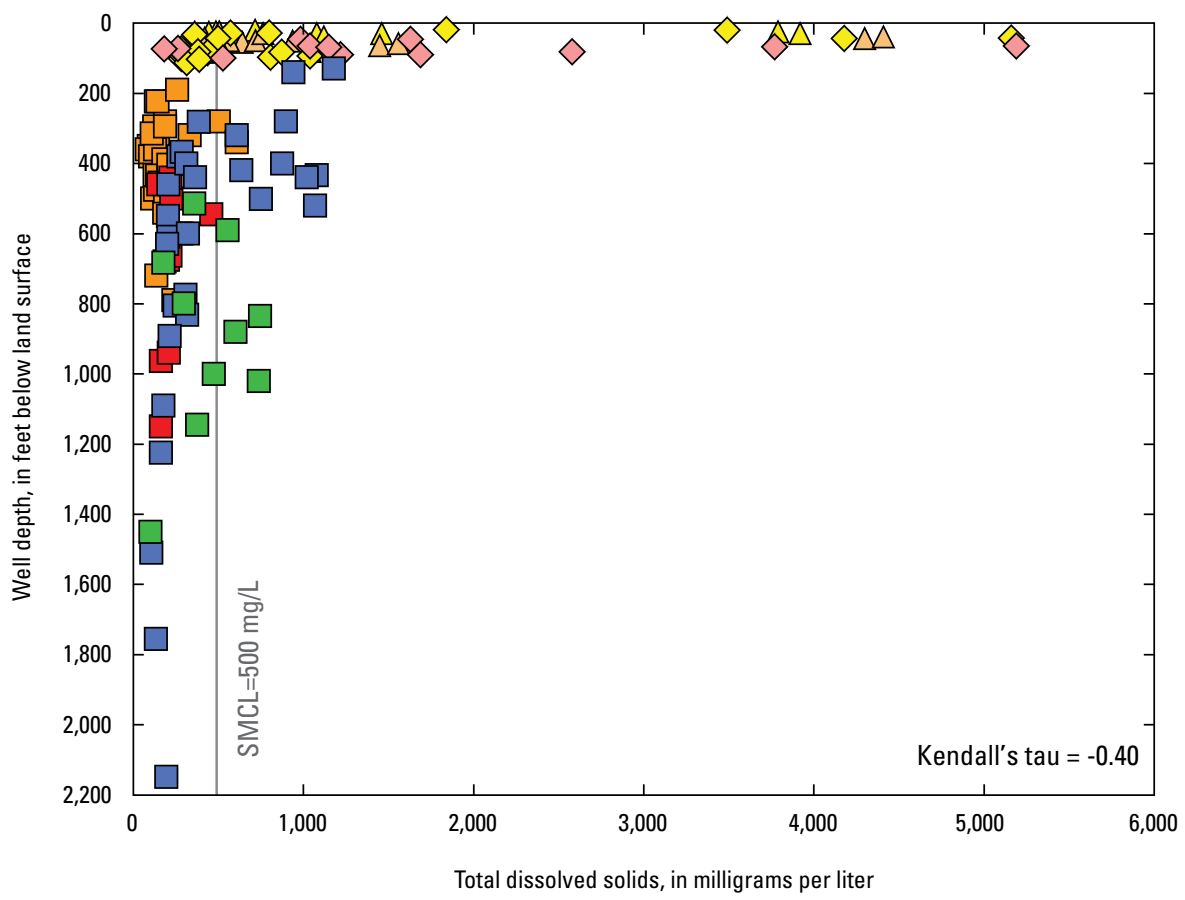

EXPLANATION

Water-table well, by land use and aquifer

Agricultural land use

$\diamond \quad$ Alluvial aquifer

$\diamond \quad$ Denver aquifer Urban land use

$\triangle \quad$ Alluvial aquifer

$\triangle \quad$ Dawson aquifer Bedrock-aquifer well, by aquifer

$\square$ Dawson aquifer

$\square \quad$ Denver aquifer

$\square \quad$ Arapahoe aquifer

$\square$ Laramie-Fox Hills aquifer

SMCL, secondary maximum contaminant level

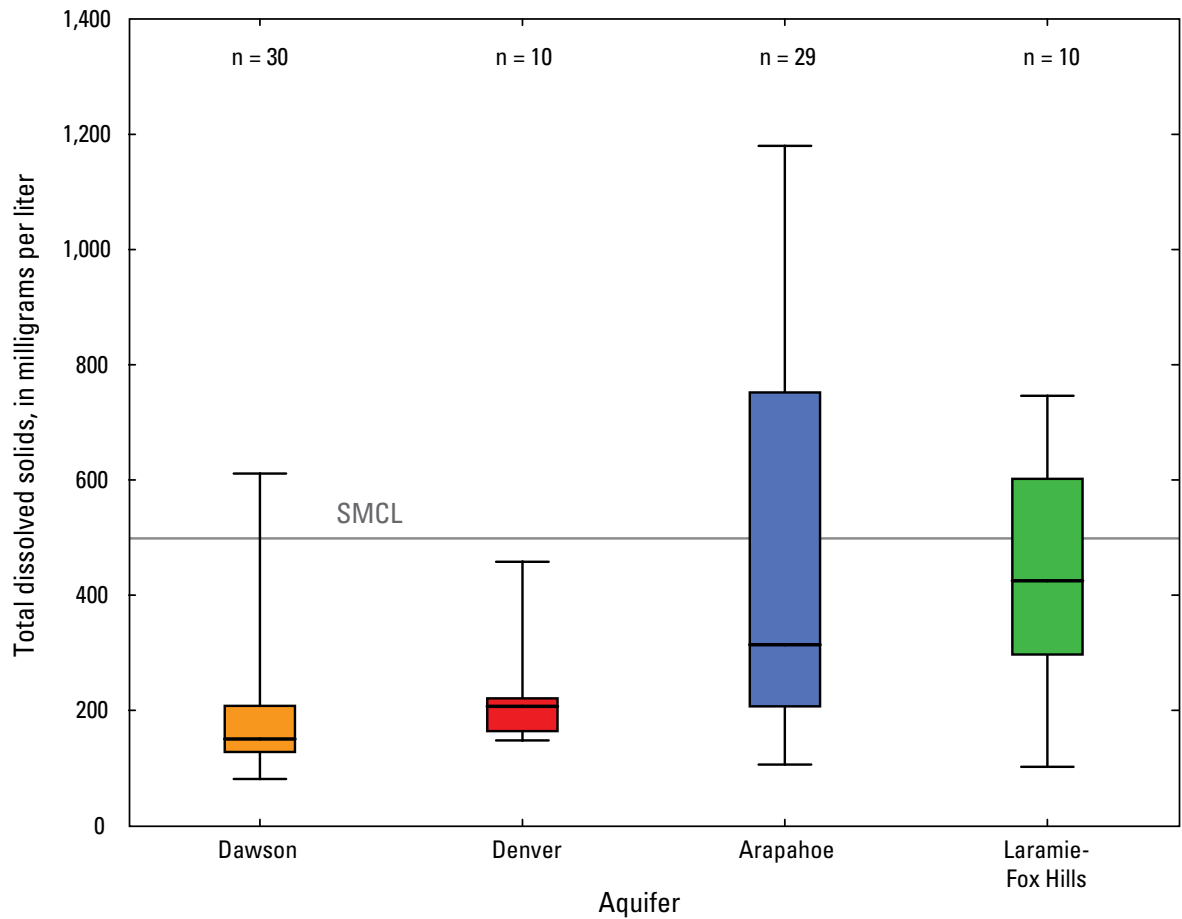

EXPLANATION

Denver Basin bedrock aquifers

$\square$ Dawson aquifer

Denver aquifer

$\square$ Arapahoe aquifer

Laramie-Fox Hills aquifer

$n=10 \quad$ Number of samples

T Maximum value

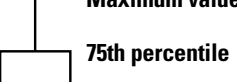

25th percentile

Minimum value

SMCL, secondary maximum contaminant level

Figure 11. Distribution of total dissolved solids concentrations for groundwater samples, Denver Basin aquifer system, Colorado, 2003-5. A, Relation with well depth. $B$, Distribution by bedrock aquifer. 
In the absence of other sources of dissolved constituents, TDS concentrations would be expected to generally increase along flow paths as a result of progressive water-rock interaction. Other processes, however, such as accumulation of salts through evaporation, and human-related processes such as cyclical wetting and drying of shallow soils associated with the application of irrigation water, likely contribute elevated TDS concentrations to shallow groundwater. In the semiarid climate of the Denver Basin, evaporation is an important process; little natural precipitation (less than 1 inch per year) reaches the subsurface as recharge (Paschke, 2011). The relatively high TDS concentrations common for shallow groundwater (fig. $11 \mathrm{~A}$ ) indicate that, in addition to natural evaporation, agricultural and urban land use in the Denver Basin is affecting water quality. These results are consistent with previous studies that have noted that the application of agricultural or urban chemicals to the land surface, combined with increased recharge from irrigation of developed land, likely has increased TDS concentrations in the groundwater (Robson, 1989; Bruce and McMahon, 1998; Paschke and others, 2008; Paschke, 2011).
For the bedrock aquifers, median TDS concentrations increased from the Dawson to Denver to Arapahoe to Laramie-Fox Hills aquifers (fig. 11B; table 5). The increase in TDS concentrations for the bedrock aquifers was accompanied by a relatively large corresponding increase in the median concentration of $\mathrm{HCO}_{3}$ (fig. 12). The relations between well depth and TDS and well depth and $\mathrm{HCO}_{3}$ for the bedrock aquifers, however, were not statistically significant; this likely partially reflects spatial variability in bedrock-aquifer chemistry resulting from progressive water-rock interaction along regional flow paths. Previous studies have noted relatively high TDS concentrations along the downgradient margins of the bedrock aquifers, with concentrations increasing generally along flow paths to the north and east (Robson, 1989). This observation is consistent with the current study, where samples with the highest TDS concentrations (greater than [>] $800 \mathrm{mg} / \mathrm{L}$ ) were primarily collected from wells located along the northern and eastern downgradient margins of the basin (fig. 13).

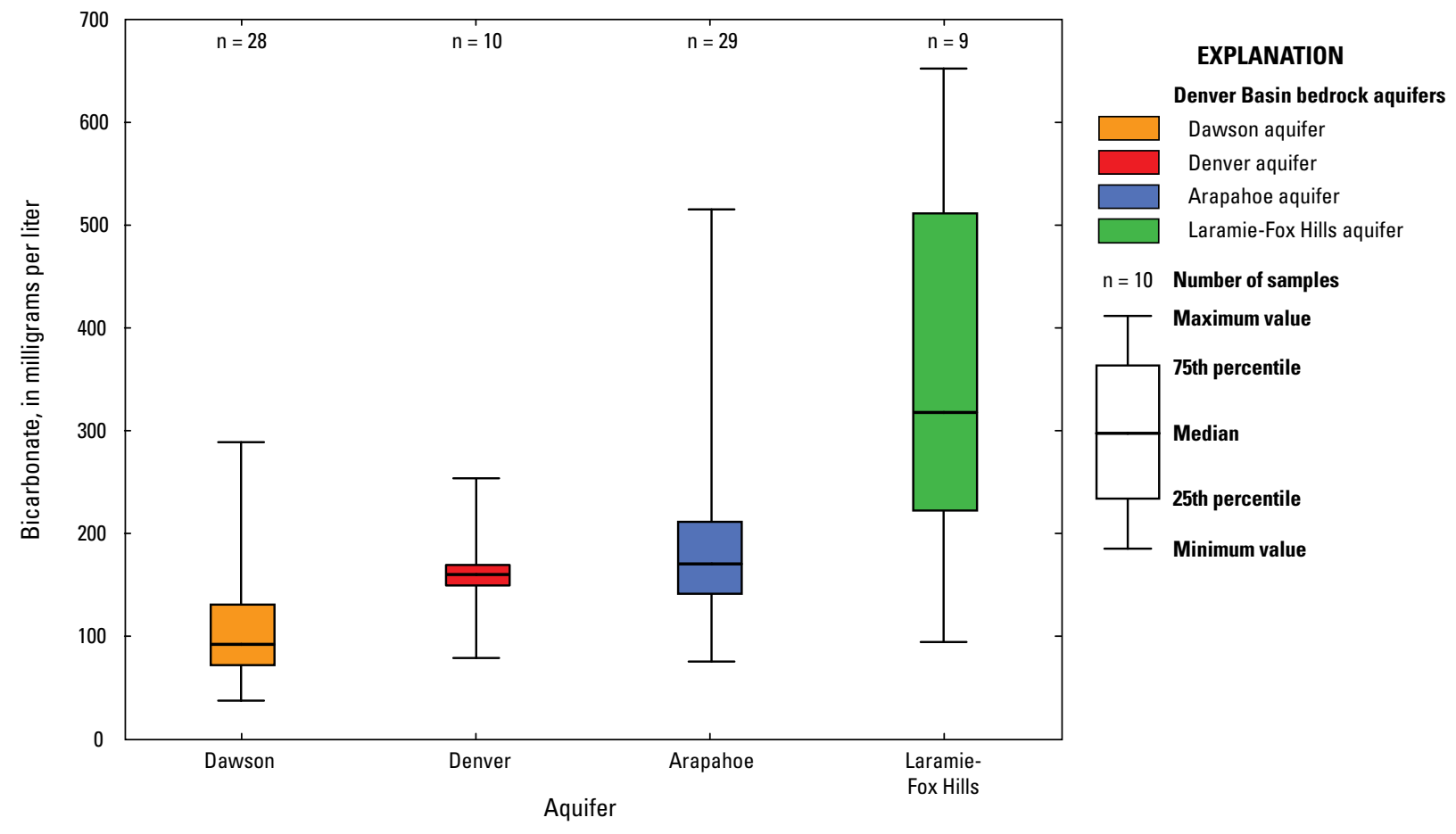

Figure 12. Distribution of bicarbonate concentration by bedrock aquifer for groundwater samples, Denver Basin aquifer system, Colorado, 2003-5. 


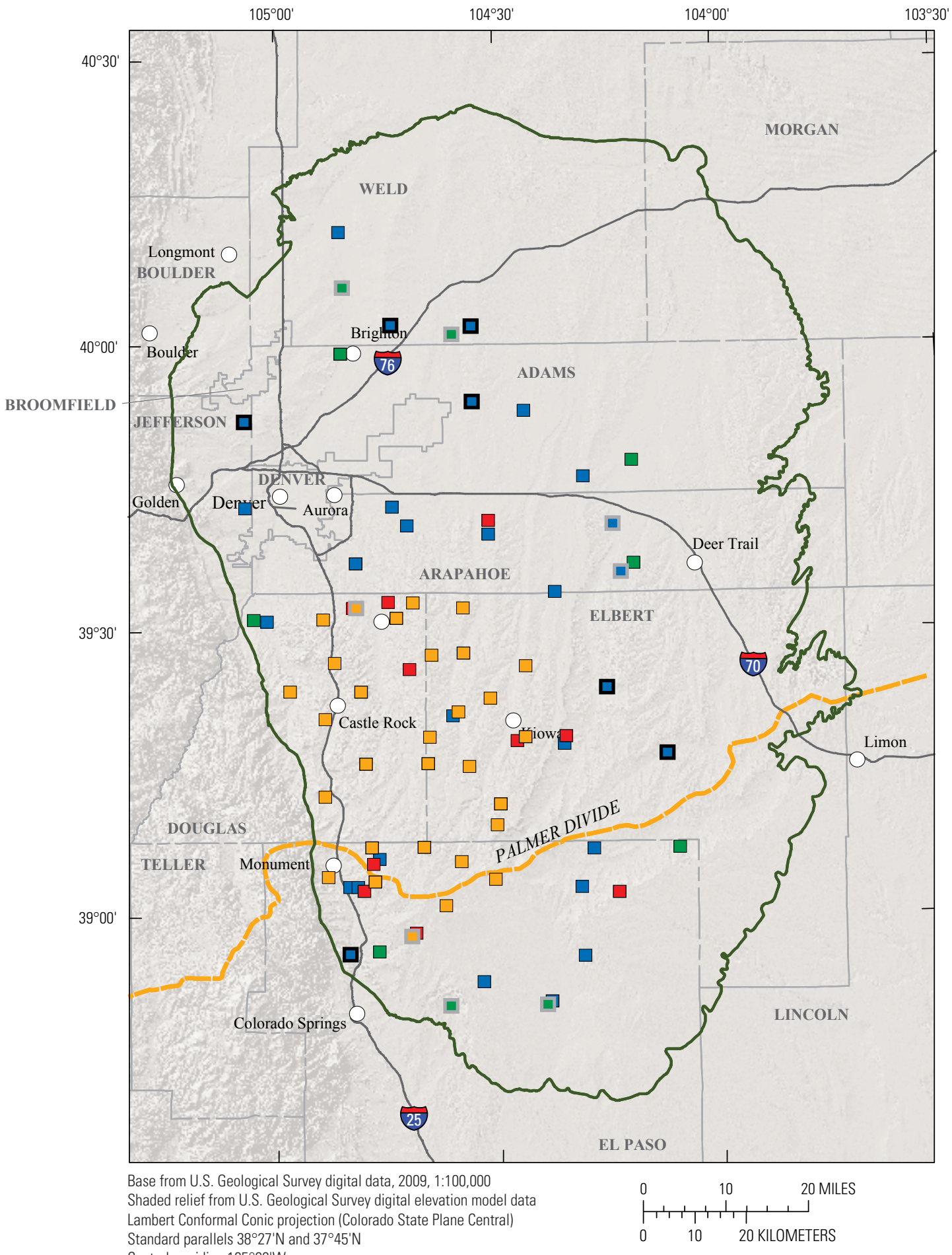

Central meridian $105^{\circ} 00^{\prime} \mathrm{W}$

\section{EXPLANATION}

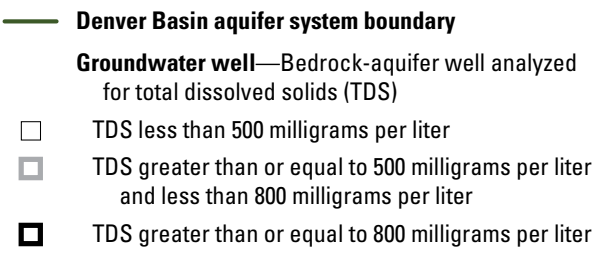

Denver Basin bedrock-aquifer well, by aquifer

$\square \quad$ Dawson aquifer

$\square \quad$ Denver aquifer

$\square \quad$ Arapahoe aquifer

$\square \quad$ Laramie-Fox Hills aquifer

口 TDS greater than or equal to 800 milligrams per liter

Figure 13. Hydrogeologic setting and location of sampled wells distinguished by total dissolved solids concentrations, Denver Basin aquifer system, Colorado, 2003-5. 
Cation exchange is an important water-rock interaction process affecting major-ion chemistry, by which dissolved ions in groundwater are exchanged with ions sorbed onto the surface of clay minerals; common ion-exchange processes include the exchange of dissolved $\mathrm{Ca}$ and $\mathrm{Mg}$ for $\mathrm{Na}$ (Appelo and Postma, 2005). In clay-rich aquifers, exchange processes can result in a decrease in dissolved $\mathrm{Ca}$ and $\mathrm{Mg}$ concentrations and an increase in dissolved $\mathrm{Na}$ concentrations along flow paths. In the bedrock aquifers, median Ca concentrations decreased from the Dawson to Denver to Arapahoe to Laramie-Fox Hills aquifers, with a corresponding increase in median Na concentrations (table 5). The "Na excess," which is the ratio of the molar concentration of Na relative to the sum of the molar concentration of $\mathrm{Ca}$ and $\mathrm{Mg}(\mathrm{Na} /[\mathrm{Ca}+\mathrm{Mg}])$, increased from the Dawson to Denver to Arapahoe to Laramie-Fox Hills aquifers, which indicates that cation exchange is an important process affecting major-ion chemistry in the bedrock aquifers (fig. 14). These results are consistent with the transition from predominantly $\mathrm{Ca}-\mathrm{HCO}_{3}$ waters in shallow groundwater in the Dawson aquifer to predominantly $\mathrm{Na}-\mathrm{HCO}_{3}$ waters in the deeper Arapahoe and Laramie-Fox Hills aquifers (fig. 10). Previous studies have also noted that this process occurs in the bedrock aquifers, as evidenced by the transition from $\mathrm{Ca}-\mathrm{HCO}_{3}$ to $\mathrm{Na}-\mathrm{HCO}_{3}$ and $\mathrm{Na}-\mathrm{SO}_{4}$ compositions with depth and along flow paths (Robson, 1987).

\section{Oxidation-Reduction and $\mathrm{pH}$ Conditions}

Redox and $\mathrm{pH}$ conditions in an aquifer exert strong control on a variety of geochemical processes and can affect contaminant and trace-element concentrations and speciation in groundwater (McMahon and others, 2009). Redox conditions in the Denver Basin evolved from mostly oxic or mixed for the water-table wells to mostly anoxic, or reducing, in the deeper bedrock aquifers (fig. 15). DO concentrations were wide ranging in samples from the water-table wells, with values ranging from 0.1 to $17.4 \mathrm{mg} / \mathrm{L}$; concentrations for the agricultural land-use wells (median $=7.2 \mathrm{mg} / \mathrm{L}$ ) were generally higher, with mostly oxic conditions, than those for the urban land-use wells (median $=1.6 \mathrm{mg} / \mathrm{L}$ ), which were mostly oxic and mixed redox conditions (fig. 15; table 5). The uppermost bedrock aquifer, the Dawson aquifer, was characterized by mostly oxic conditions (median DO concentration $=3.8 \mathrm{mg} / \mathrm{L}$ ), whereas conditions for the lower bedrock aquifers were mostly anoxic (fig. 15), with low median DO concentrations of less than $0.5 \mathrm{mg} / \mathrm{L}$ (table 5). DO concentrations for the Denver Basin generally decreased with depth, reflected in increasingly anoxic conditions, as did concentrations for the redox species $\mathrm{NO}_{3}$ (fig. 16), which is consistent with the progression of redox processes. Several samples from the Arapahoe, Denver, and Laramie-Fox Hills aquifers, however, were oxic, which might reflect mixing with shallow oxic recharge.

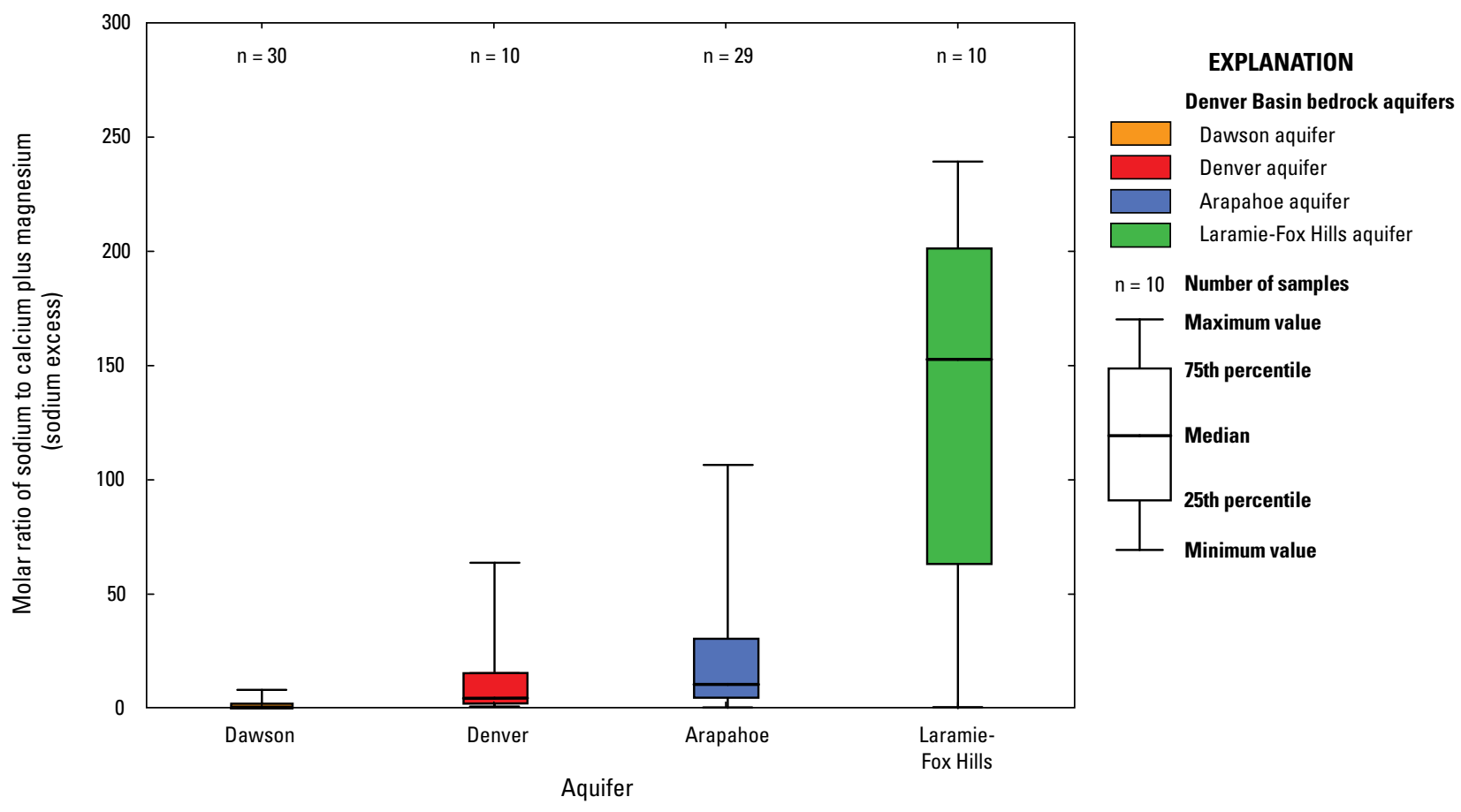

Figure 14. Distribution of the molar ratio of sodium to calcium plus magnesium (sodium excess) by bedrock aquifer for groundwater samples, Denver Basin aquifer system, Colorado, 2003-5. 


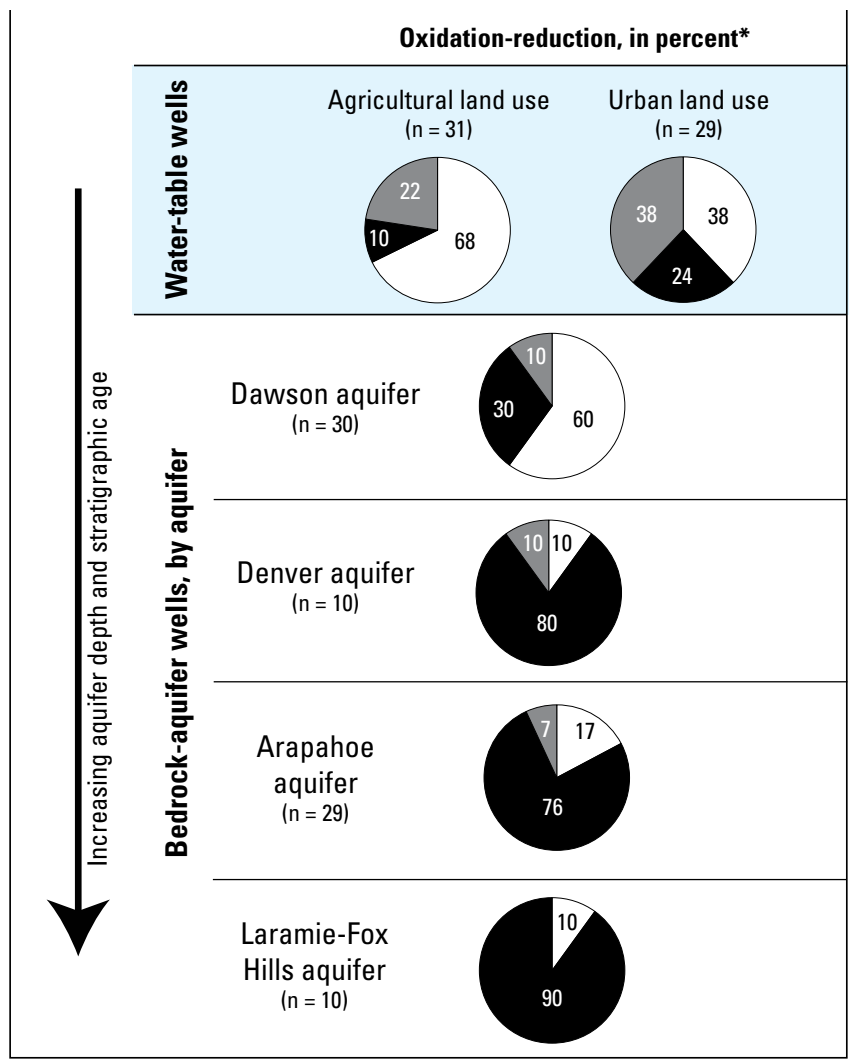

*Evaluated with the classification of McMahon and Chapelle (2008), using the software of Jurgens and others (2009).

Figure 15. Oxidation-reduction classification for groundwater samples, Denver Basin aquifer system, Colorado, 2003-5.

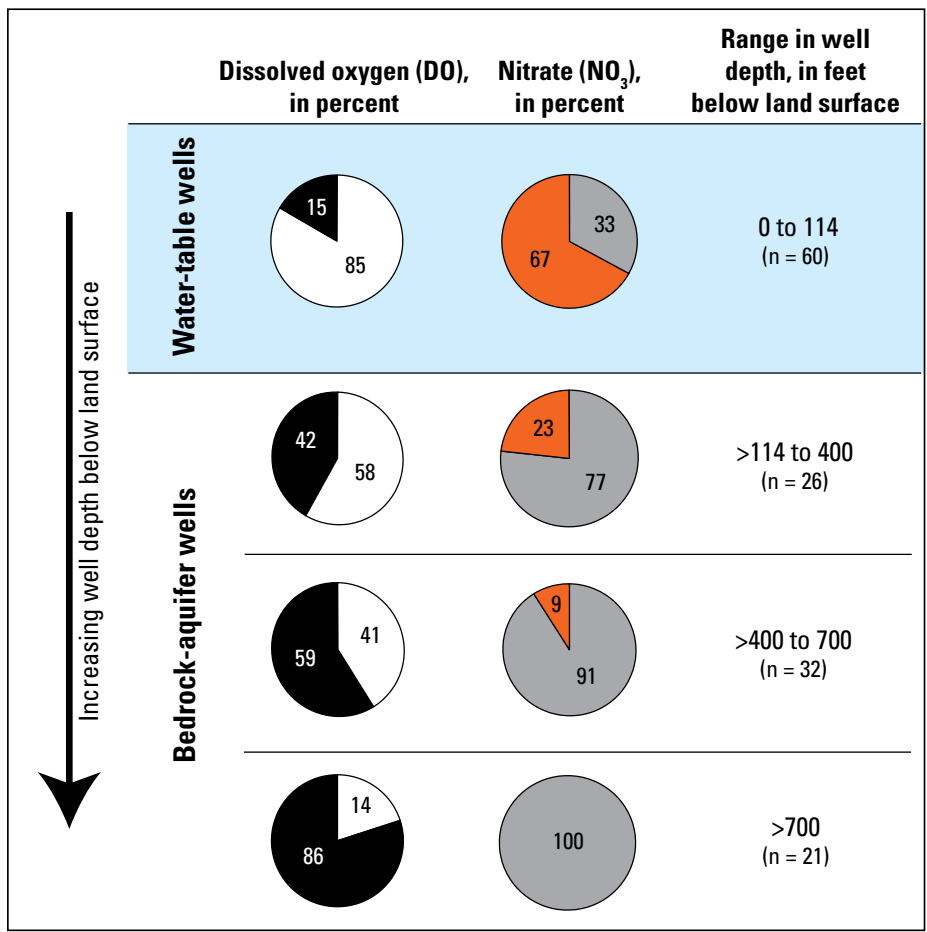

\section{EXPLANATION}

Dissolved oxygen (DO)

Anoxic-D0 $<0.5 \mathrm{mg} / \mathrm{L}$

$0 x i c-D 0 \geq 0.5 \mathrm{mg} / \mathrm{L}$

Nitrate $\left(\mathrm{NO}_{3}\right)$

$\square \mathrm{NO}_{3}<1 \mathrm{mg} / \mathrm{L}$

$\mathrm{NO}_{3} \geq 1 \mathrm{mg} / \mathrm{L}$

$\mathrm{mg} / \mathrm{L}$, milligrams per liter

$n$, number of samples

$<$, less than

$\geq$, greater than or equal to

$>$, greater than

Figure 16. Distribution of dissolved oxygen and nitrate concentrations for groundwater samples, Denver Basin aquifer system, Colorado, 2003-5. 
Concentrations of Fe and Mn were correlated (Kendall's tau $=0.41$ ), although concentrations were highly variable within each aquifer (fig. 17A; table 5). Samples with relatively high $\mathrm{Mn}$ and $\mathrm{Fe}$ concentrations from the bedrock aquifers were generally associated with relatively low $\mathrm{DO}$ and $\mathrm{NO}_{3}$ concentrations (fig. 17B), consistent with the progression of redox processes. Median concentrations of $\mathrm{SO}_{4}$ decreased markedly from the Arapahoe to Laramie-Fox Hills aquifers, consistent with more reducing conditions (table 5); $\mathrm{SO}_{4}$ concentrations in the Arapahoe and Laramie-Fox Hills aquifers were variable, indicating that $\mathrm{SO}_{4}$-reducing conditions likely occur locally in these aquifers. Several samples from the Laramie-Fox Hills aquifer had detectable concentrations of methane (as much as $10.29 \mathrm{mg} / \mathrm{L}$ ), possibly indicating the presence of methanogenic conditions locally or mixing with water affected by methanogenesis. The increase in $\mathrm{HCO}_{3}$ associated with the deeper bedrock aquifers (fig. 12) is likely partially controlled by the progression of redox processes (such as $\mathrm{NO}_{3}$ reduction), which results in the generation of $\mathrm{HCO}_{3}$ (Appelo and Postma, 2005).

In addition to redox conditions, $\mathrm{pH}$ can affect the speciation, transport, and transformation of many waterquality constituents including redox species like $\mathrm{Mn}$ and $\mathrm{Fe}$, trace elements such as Se and $\mathrm{U}$ (which are also redox sensitive), and some organic compounds. $\mathrm{pH}$ values for the Denver Basin aquifer system ranged from 5.9 to 9.4 and were mostly (94 percent) within the SMCL range of 6.5 to 8.5. Values of $\mathrm{pH}$ in samples from the water-table wells were mostly near neutral (table 5). In contrast, values of $\mathrm{pH}$ in the bedrock-aquifer samples generally increased with depth, becoming more alkaline in the deeper bedrock aquifers (fig. 18; table 5). Values of $\mathrm{pH}$ are affected by a complex mix of water-rock interaction processes, which generally result in increasing $\mathrm{pH}$ values along flow paths as hydrogen is consumed during mineral weathering reactions (Hem, 1992).

\section{Nutrients and Organic Carbon}

Nutrients are elements important for plant growth and survival and include the primary mineral nutrients $\mathrm{N}$, phosphorus $(\mathrm{P})$, and $\mathrm{K}$. N is the most soluble of these nutrients, which generally occurs in groundwater as $\mathrm{NO}_{3}, \mathrm{NO}_{2}$, and ammonium $\left(\mathrm{NH}_{4}\right)(\mathrm{Hem}, 1992) . \mathrm{NO}_{3}$ and $\mathrm{NO}_{2}$ are readily transported in groundwater, whereas $\mathrm{NH}_{4}$ strongly adsorbs onto mineral surfaces (Hem, 1992). Denitrification (that is, the reduction of $\mathrm{NO}_{3}$ to $\mathrm{N}_{2}$ ) occurs in anoxic conditions and is an important geochemical process affecting $\mathrm{N}$ concentrations; it is the only mechanism for natural attenuation of $\mathrm{NO}_{3}$ in groundwater. Humans have transformed the global $\mathrm{N}$ cycle, and elevated nutrient concentrations in water resources are an issue of worldwide concern (Schlesinger and others, 2006; Galloway and others, 2008). The national background concentration of $\mathrm{NO}_{3}$ in groundwater has been estimated to be about $1 \mathrm{mg} / \mathrm{L}$ (Dubrovsky and others, 2010), and concentrations greater than about $1 \mathrm{mg} / \mathrm{L}$ typically indicate human sources and (or) processes (note that all discussion of $\mathrm{N}$ species in this report is for concentrations reported "as N" $\left.\left[\mathrm{NO}_{3}-\mathrm{N}\right]\right)$. Groundwater contamination from nutrients, such as $\mathrm{NO}_{3}$, is widespread throughout the Nation (Nolan and others, 1998; Dubrovsky and others, 2010). Sources of N include agricultural fertilizers (synthetic fertilizers often contain ammonia, ammonium nitrate, urea, or other $\mathrm{N}$ compounds), animal wastes, septic systems, municipal sewage-treatment systems, leaking sewer lines, urban runoff, and $\mathrm{N}$-oxide emissions. The MCL for $\mathrm{NO}_{3}$ is $10 \mathrm{mg} / \mathrm{L}$.

Concentrations of $\mathrm{NO}_{3}$ are redox sensitive and decreased with depth in the Denver Basin (figs. 16 and 19). Concentrations of $\mathrm{NO}_{2}$ were negligible when detected and were less than LRLs for most samples (table 5). The median $\mathrm{NO}_{3}$ concentration was higher for samples from the water-table wells relative to those from the bedrock aquifers (table 5). For the water-table well samples, the median $\mathrm{NO}_{3}$ concentration was higher for the agricultural land-use wells (median $=6.42 \mathrm{mg} / \mathrm{L}$ ) than for the urban land-use wells $($ median $=4.02 \mathrm{mg} / \mathrm{L})($ table 5$)$, but the difference between the groups was not significant (on the basis of the Mann-Whitney U test).

Previous studies in the Denver Basin and South Platte River alluvial aquifer have noted an association between land use and water-quality degradation of alluvial groundwater, with high $\mathrm{NO}_{3}$ concentrations occurring in agricultural areas (Bruce and McMahon, 1998; Dennehy and others, 1998; Paschke and others, 2008). $\mathrm{NO}_{3}$ concentrations in previous studies were also higher in agricultural areas (median $=9.4$ $\mathrm{mg} / \mathrm{L}$ ) than in urban areas (median $=2.1 \mathrm{mg} / \mathrm{L}$ ), although groundwater from both land uses was likely affected by human sources (Bruce and McMahon, 1998). Flow path study results for previous studies indicate that denitrification was an important process that reduced $\mathrm{NO}_{3}$ concentrations in the alluvial aquifer (Paschke and others, 2008). 


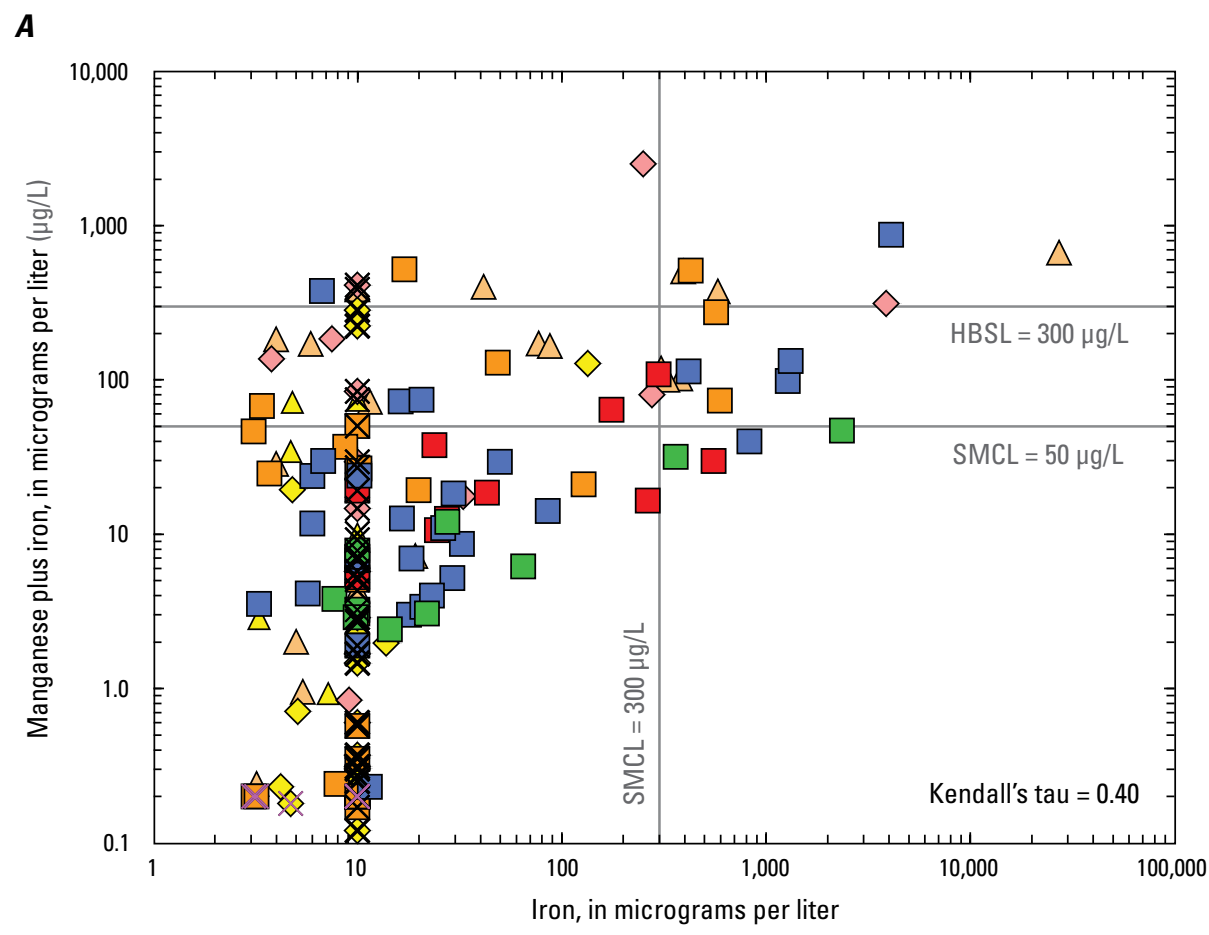

EXPLANATION

Water-table well, by land use and aquifer

Agricultural land use

$\diamond \quad$ Alluvial aquifer

$\diamond \quad$ Denver aquifer Urban land use

$\triangle \quad$ Alluvial aquifer

$\triangle \quad$ Dawson aquifer

Bedrock-aquifer well, by aquifer

$\square \quad$ Dawson aquifer

$\square \quad$ Denver aquifer

$\square \quad$ Arapahoe aquifer

$\square$ Laramie-Fox Hills aquifer

$X$ Nondetection (X-axis), shown at the laboratory reporting level (LRL)

X Nondetection (Y-axis),

shown at the LRL

SMCL, secondary maximum contaminant level HBSL, health-based screening level

$\boldsymbol{B}$

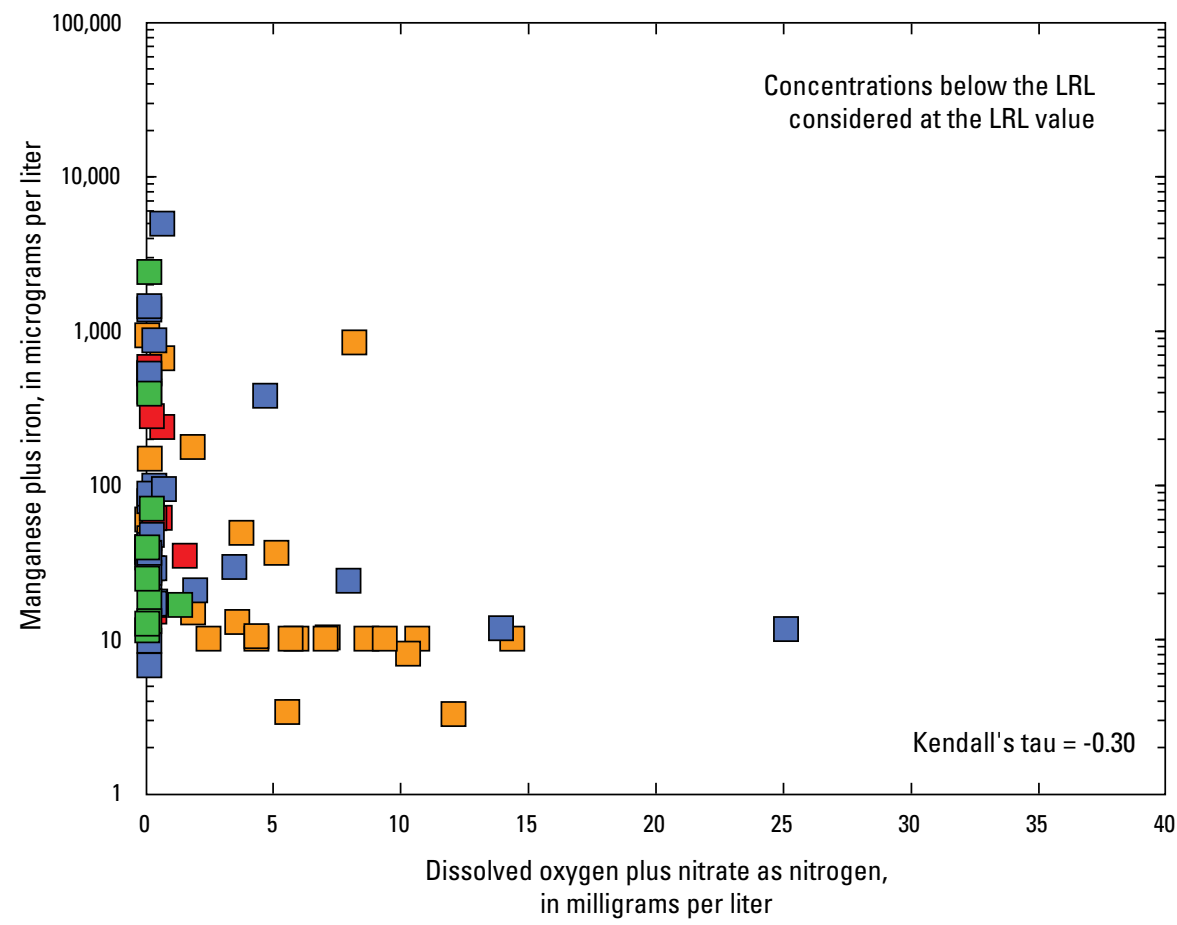

Figure 17. Dissolved-constituent relations for groundwater samples, Denver Basin aquifer system, Colorado, 2003-5. A, Relation between iron and manganese concentrations. $B$, Relation between dissolved oxygen plus nitrate concentration and manganese plus iron concentration for bedrock aquifers. 


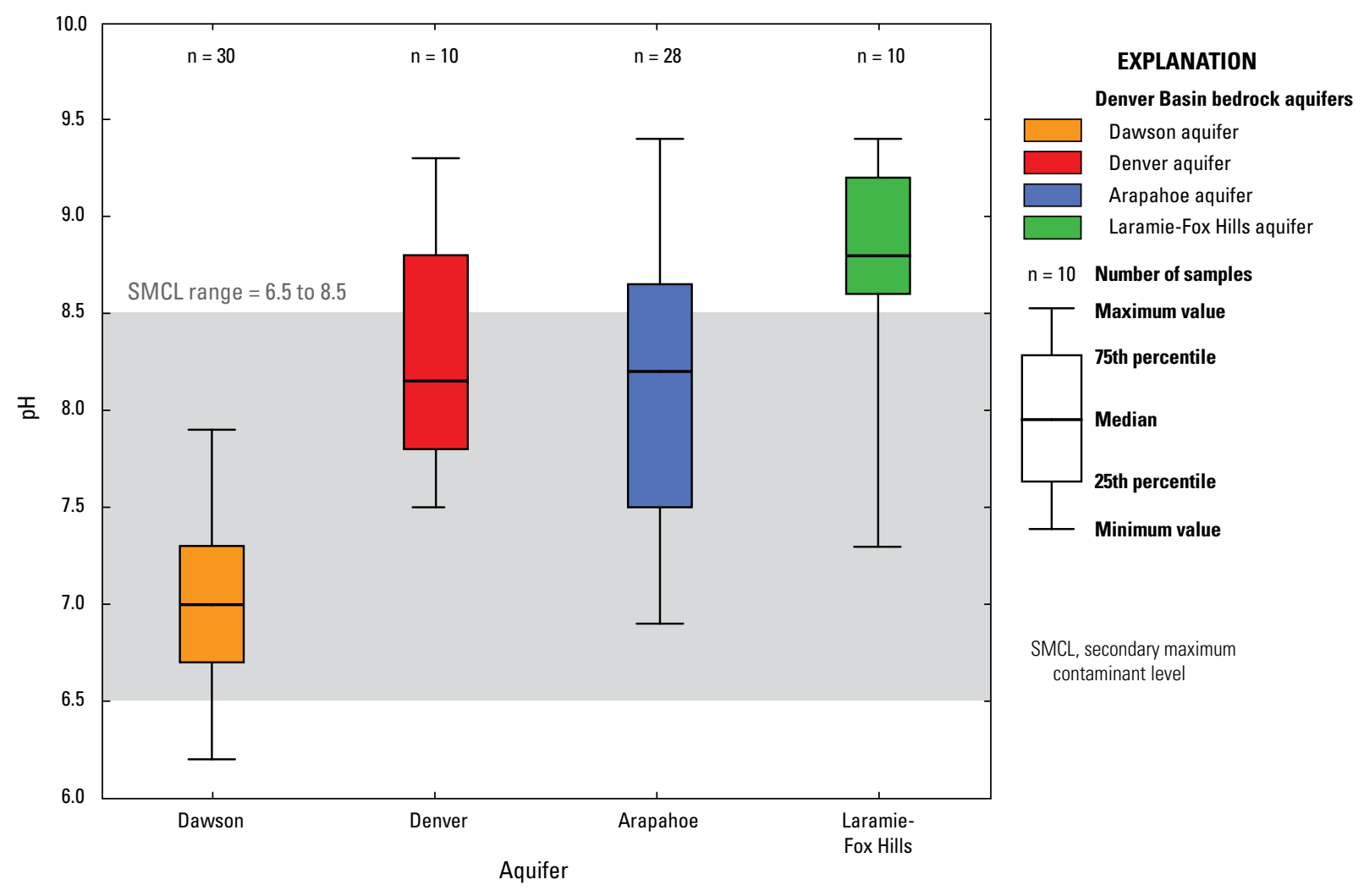

Figure 18. Distribution of $\mathrm{pH}$ values for groundwater samples from the bedrock aquifers, Denver Basin aquifer system, Colorado, 2003-5.

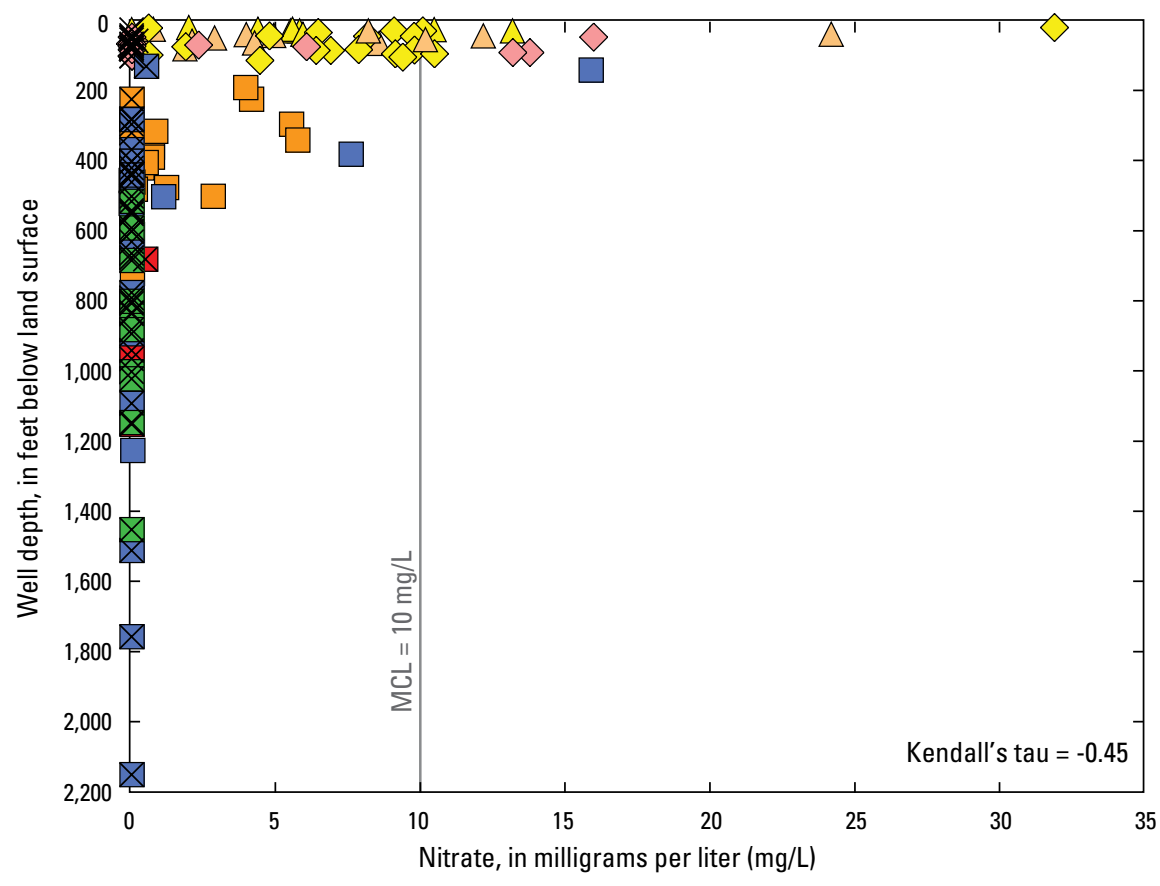

\section{EXPLANATION}

Water-table well, by land use and aquifer

Agricultural land use

$\diamond \quad$ Alluvial aquifer

$\diamond \quad$ Denver aquifer Urban land use

$\triangle \quad$ Alluvial aquifer

$\triangle \quad$ Dawson aquifer

Bedrock-aquifer well, by aquifer

$\square \quad$ Dawson aquifer

$\square$ Denver aquifer

$\square \quad$ Arapahoe aquifer

$\square \quad$ Laramie-Fox Hills aquifer

$X$ Nondetection (X-axis), shown at the laboratory reporting level

MCL, maximum contaminant level

Figure 19. Relation between well depth and nitrate concentration for groundwater samples, Denver Basin aquifer system, Colorado, 2003-5. 
Eighteen percent of the water-table well samples ( 5 samples from the urban land-use wells and 6 from the agricultural land-use wells) exceeded the $\mathrm{NO}_{3} \mathrm{MCL}$ (table 5). For the bedrock aquifers, one sample from a relatively shallow (140 ft) Arapahoe aquifer well (ARAPMAS 07) with a concentration of $15.9 \mathrm{mg} / \mathrm{L}$ exceeded the $\mathrm{NO}_{3} \mathrm{MCL}$; age tracers were not measured for this sample, but the high $\mathrm{NO}_{3}$ concentration is likely indicative of mixing with shallow young groundwater. The sample from well ARAPMAS 24, which also had a high concentration of $\mathrm{NO}_{3}(7.63 \mathrm{mg} / \mathrm{L})$, was oxic, and age-tracer results were indicative of young water. Concentrations of $\mathrm{DO}$ and $\mathrm{NO}_{3}$ in the bedrock aquifers were well correlated (Kendall's tau $=0.64$ ). The concentrations of $\mathrm{NO}_{3}$ in groundwater from the water-table wells likely result, in part, from human activities. Concentrations for samples from the agricultural land-use wells might result from the widespread use of chemical fertilizers and (or) manure on the land surface, which is consistent with elevated $\mathrm{NO}_{3}$ concentrations in groundwater associated with agricultural land-use settings across the Nation (Spalding and Exner, 1993; Puckett, 1994; Steele and others, 2005; Paschke and others, 2008; Dubrovsky and others, 2010). The median $\mathrm{NO}_{3}$ concentration for samples from the agricultural landuse wells $(6.42 \mathrm{mg} / \mathrm{L}$; table 5$)$, which were in non-irrigated areas, was less than that for the South Platte River Basin irrigated agricultural study conducted in 1993-95 (median = $9.35 \mathrm{mg} / \mathrm{L}$ ) (Bruce and McMahon, 1998). When resampled in 2002, the South Platte River Basin irrigated agricultural wells had a median concentration of $10 \mathrm{mg} / \mathrm{L}$ (Paschke and others, 2008). Lower $\mathrm{NO}_{3}$ concentrations for non-irrigated agricultural areas likely reflect, in part, differences in the application of irrigation water and the resulting transport of $\mathrm{NO}_{3}$ in the subsurface. Additionally, fertilizer application rates vary with crop type, with relatively low application rates for non-irrigated wheat in comparison to irrigated crops such as corn (Davis and Westfall, 2009a, 2009b). Elevated $\mathrm{NO}_{3}$ concentrations in the urban land-use wells (median = $4.02 \mathrm{mg} / \mathrm{L}$; table 5) also likely are affected by loading of $\mathrm{N}$ from human sources. About half of all water use in urban areas along the Front Range is used outdoors, mostly for landscape and turf watering (Waskom and Neibauer, 2010). The median $\mathrm{NO}_{3}$ concentration for samples collected from water-table wells in urban areas of the Denver metropolitan area in a previous study (1993-95) was $2.1 \mathrm{mg} / \mathrm{L}$ (Bruce and McMahon, 1998). Although the same wells sampled in Bruce and McMahon (1998) were not sampled in the current study (and thus direct comparison of results is not possible), the higher median $\mathrm{NO}_{3}$ concentration in the current study might reflect increased loading of $\mathrm{NO}_{3}$ in urban areas from human sources.

Elevated $\mathrm{NO}_{3}$ concentrations have been noted to occur naturally in soils in some arid and semiarid settings, accumulated through processes such as atmospheric deposition or biological $\mathrm{N}$ fixation (Walvoord and others, 2003; Graham and others, 2008). Leaching of such high- $\mathrm{NO}_{3}$ soils, such as through irrigation, can result in high $\mathrm{NO}_{3}$ concentrations in groundwater (Edmunds and Gaye, 1997). While the background concentration for $\mathrm{NO}_{3}$ in groundwater has been estimated to be $1 \mathrm{mg} / \mathrm{L}$, the concentration varies regionally (Dubrovsky and others, 2010); the background $\mathrm{NO}_{3}$ concentration for the High Plains aquifer, for example, has been estimated to be $4 \mathrm{mg} / \mathrm{L}$ (Gurdak and Qi, 2006). A study of $\mathrm{NO}_{3}$ concentrations in mountain streams in the South Platte River Basin found that concentrations of $\mathrm{NO}_{3}$ correlated with the degree of development in the basin, indicative of human $\mathrm{NO}_{3}$ sources (Dennehy and others, 1998). Additionally, previous studies in the South Platte River Basin have documented the occurrence of $\mathrm{NO}_{3}$ "hot spots," for which locations were related to soil texture and fertilizer applications (Wylie and others, 1993). $\mathrm{NO}_{3}$ isotopes, which were not analyzed for the current study, would provide further insight into sources of $\mathrm{NO}_{3}$ in the Denver Basin.

The decrease in $\mathrm{NO}_{3}$ concentrations with depth was associated with a shift in redox conditions from mostly oxic near the water table to mostly anoxic in the deeper bedrock aquifers (fig. 16). In addition to redox processes and denitrification, the decrease in $\mathrm{NO}_{3}$ with depth and the relatively low $\mathrm{NO}_{3}$ concentrations in the bedrock aquifers (table 5) might also be influenced by older groundwater associated with long residence times and flow paths in the deeper bedrock aquifers that recharged prior to recent and extensive $\mathrm{NO}_{3}$ loading to groundwater associated with agriculture and urban development in the basin. Groundwater age estimates are discussed in the section "Groundwater Age Tracers and Age Distributions."

Organic $\mathrm{N}$ and ammonia $\left(\mathrm{NH}_{3}\right)$ concentrations were generally low (table 5), indicating that $\mathrm{N}$ in groundwater in the Denver Basin is predominantly in the form of $\mathrm{NO}_{3}$. $\mathrm{NH}_{3}$ was generally not detected or was detected at low concentrations in samples from the water-table wells (table 5), although fertilizers containing $\mathrm{NH}_{3}$ are used regionally; two samples from the agricultural land-use wells had $\mathrm{NH}_{3}$ concentrations greater than $1 \mathrm{mg} / \mathrm{L}$. For the bedrock aquifers, the median $\mathrm{NH}_{3}$ concentration increased from the shallower to the deeper aquifers, from $<0.04 \mathrm{mg} / \mathrm{L}$ for the Dawson aquifer to 0.53 $\mathrm{mg} / \mathrm{L}$ for the Laramie-Fox Hills aquifer (table 5). The increase in $\mathrm{NH}_{3}$ concentration is correlated with an increase in $\mathrm{pH}$ for the bedrock aquifers (Kendall's tau $=0.50$ ) and likely relates to the reduction of organic $\mathrm{N}$ or other $\mathrm{N}$ species to $\mathrm{NH}_{3}$ under reducing redox conditions. Median organic $\mathrm{N}$ concentrations for all aquifers in the Denver Basin were less than LRLs (table 5).

Concentrations of DOC in the Denver Basin aquifer system decreased with depth (Kendall's tau $=-0.60$ ), with relatively high concentrations in samples from the water-table wells in comparison with those from the bedrock aquifers (table 5). The decrease in DOC likely results in part from its consumption during microbially catalyzed redox reactions. DOC concentrations for samples from the water-table wells were highly variable $(0.58$ to $81.9 \mathrm{mg} / \mathrm{L}$; table 5$)$, which indicates that some water-table wells might be located near areas that receive recharge with elevated DOC concentrations. 
Some of the highest measured DOC concentrations, however, might result from insufficient removal of methanol from sampling equipment during cleaning (DOC was detected in about half of the field blanks [table 6] at concentrations from E0.21 to $1.12 \mathrm{mg} / \mathrm{L}$ ). For the water-table well samples, median DOC values were higher for the urban land-use wells (median $=4.46 \mathrm{mg} / \mathrm{L}$ ) than for the agricultural land-use wells (median $=2.98 \mathrm{mg} / \mathrm{L})($ table 5$)$, but the difference between the groups was not significant (on the basis of the Mann-Whitney $U$ test). DOC concentrations were lower and less variable in the bedrock aquifers $(<0.33-4.39 \mathrm{mg} / \mathrm{L}$; table 5$)$. Some variability in DOC concentrations likely results, in part, from differences in depositional environments and corresponding lithology; for example, lignite occurs in the bedrock aquifers and confining units (table 1).

\section{Trace Elements and Radionuclides}

Trace elements and radionuclides can cause adverse health effects at concentrations above human-health benchmarks but typically occur in low concentrations in groundwater (Ayotte, Gronberg, and others, 2011). Many trace elements occur naturally as minor constituents in geologic materials including soils, minerals, and rocks (Hem, 1992). Specific trace elements and radionuclides of interest for the Denver Basin are Se, U, As, Rn, Fe, and Mn. The mobility of these and other trace elements is affected by redox and $\mathrm{pH}$ conditions (McMahon and others, 2009). Sources of $\mathrm{Fe}$ to groundwater include the dissolution of Fe-oxide coatings on rocks and minerals and weathering of Fe-bearing silicate minerals. In the Denver Basin, Mn is present in unconsolidated sediments of the unsaturated zone and in the sedimentary rocks of the bedrock aquifers. Se, U, and As, which occur naturally in sediments and rocks of the Denver Basin, have established MCLs for drinking water (50, 30, and $10 \mu \mathrm{g} / \mathrm{L}$, respectively; table 5). Se can be toxic to aquatic life, and Colorado has a Se standard $(4.6 \mu \mathrm{g} / \mathrm{L})$ for aquatic life (Colorado Department of Public Health and Environment, 2013). An MCL (300 pCi/L) and an alternative MCL (4,000 $\mathrm{pCi} / \mathrm{L}$ ) have been proposed for Rn (table 5); the applicability of the different proposed standards would be based on how mitigation efforts are implemented (U.S. Environmental Protection Agency, 2013). Non-health-based SMCLs have been established for $\mathrm{Fe}(300 \mu \mathrm{g} / \mathrm{L})$ and $\mathrm{Mn}(50 \mu \mathrm{g} / \mathrm{L})$ (table 5) for concerns such as taste and odor, color, corrosion, staining, and (or) scaling (U.S. Environmental Protection Agency, 2011). Manganese also has an HBSL of $300 \mu \mathrm{g} / \mathrm{L}$ (table 5); although $\mathrm{Mn}$ is an essential nutrient at low concentrations, adverse health effects can be caused by chronic exposure to high doses (U.S. Environmental Protection Agency, 2004a).

Se in streams in the Denver Basin is likely derived from groundwater discharge; concentrations historically have been relatively high with exceedances of aquatic-life standards (Herring and Walton-Day, 2007; Paschke and others, 2013). Numerous segments of the South Platte River and its tributary streams have been designated as impaired with respect to concentrations of Se (Colorado Department of Public Health and Environment, 2010). Toll Gate Creek, for example, a South Platte River tributary, has consistently exceeded the aquatic-life standard, and discharge of Se-rich groundwater has been identified as a Se source to Toll Gate Creek (Herring and Walton-Day, 2007; Paschke and others, 2013). Volcanic ash and interbeds of bentonite claystone in the Dawson Arkose and Denver Formations, in particular, are considered to be major sources of Se in the Denver Basin (Paschke and others, 2013). Dissolved Se in groundwater is reactive, and Se concentrations are affected by aquifer composition, redox conditions, adsorption and desorption, and mineral precipitation-dissolution reactions (FernándezMartínez and Charlet, 2009; Paschke and others, 2013). U and As both naturally occur in sediments and rocks of the Denver Basin, and concentrations and speciation in groundwater are potentially affected by factors such as sediment and rock composition, redox conditions, $\mathrm{pH}$, and land use. $\mathrm{U}$ is generally mobile in oxic groundwater, and complexation with $\mathrm{HCO}_{3}$ can influence $\mathrm{U}$ behavior (Hem, 1992). $\mathrm{Rn}$ is a nonreactive water-soluble gas with a short half-life of 3.8 days (Hem, 1992). Although derived from U, Rn concentrations do not always correlate with $U$ concentrations in groundwater, primarily because $\mathrm{U}$ is present as a dissolved ion or complex and $\mathrm{Rn}$ is present as a dissolved gas. High concentrations of $\mathrm{Rn}$, a carcinogen, in groundwater are of concern for drinking water, primarily because the use of well water with $\mathrm{Rn}$ can be a source of $\mathrm{Rn}$ to indoor air; breathing $\mathrm{Rn}$ in indoor air is a cause of lung cancer (U.S. Environmental Protection Agency, 2013). Potential human sources of $U$ (a trace constituent in many phosphate-bearing fertilizers) and As (a component in some pesticides) are likely minor in comparison to natural geologic sources in the Denver Basin.

Concentrations of Se, U, and As generally decreased with depth in the Denver Basin, with higher concentrations occurring in the water-table well samples relative to the deeper bedrock aquifers (fig. 20; table 5). Exceedances of health-based MCLs for Se, U, and As were greater for samples from the water-table wells relative to those from the bedrock aquifers; exceedances for samples from the water-table wells were greater for the urban land-use wells relative to the agricultural land-use wells (fig. 21). The difference between samples from the urban and agricultural land-use wells was statistically significant for $U$ concentrations (on the basis of the Mann-Whitney U test). The median U concentration for samples from the urban land-use wells $(19.8 \mu \mathrm{g} / \mathrm{L}$; table 5) was similar to that previously reported for urban areas of the Denver metropolitan area $(17 \mu \mathrm{g} / \mathrm{L})$ (Bruce and McMahon, 1998), although the same wells sampled by Bruce and McMahon (1998) were not sampled in the current study (and thus direct comparison is not possible). In contrast, the median $U$ concentration for irrigated agricultural areas previously reported for the South Platte River Basin (46.5 $\mu \mathrm{g} / \mathrm{L})$ (Bruce and McMahon, 1998) was markedly higher than that for the non-irrigated agricultural areas from the current study $(6.8 \mu \mathrm{g} / \mathrm{L}$; table 5$)$. These differences likely partially result from the enhanced flow of oxic recharge in irrigated areas. 
$\boldsymbol{A}$

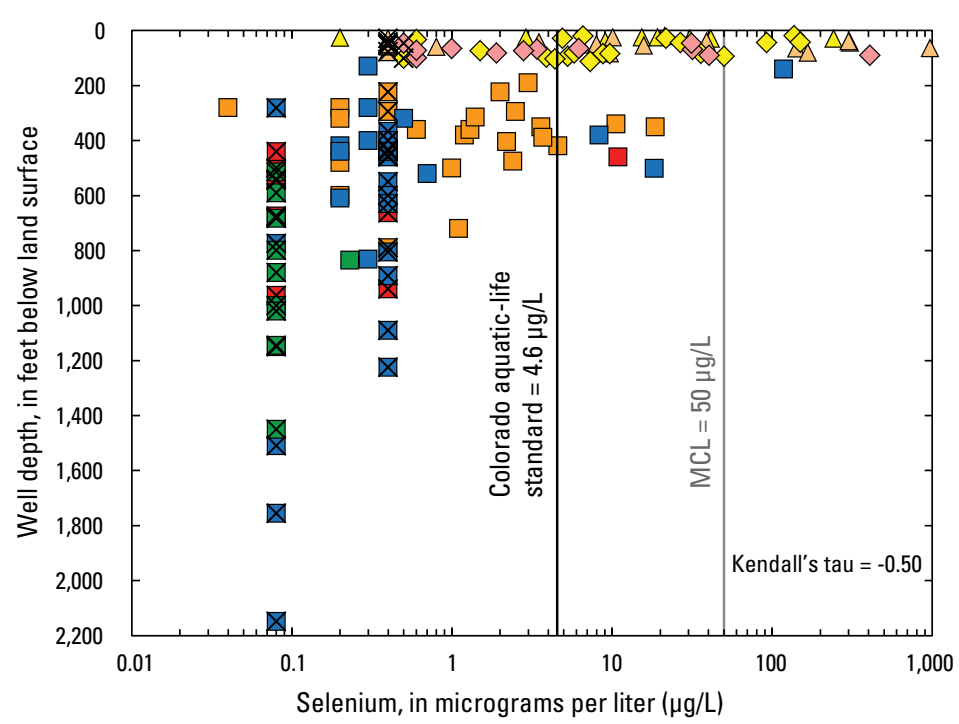

B

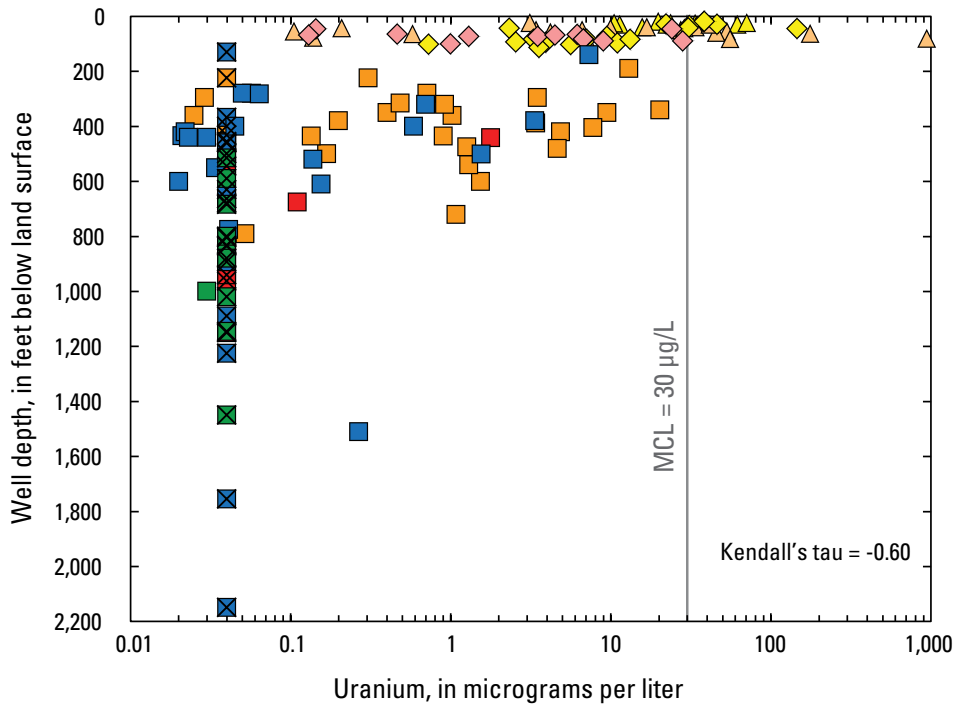

EXPLANATION

\begin{tabular}{|c|}
\hline $\begin{array}{l}\text { Water-table well, by land use } \\
\text { and aquifer }\end{array}$ \\
\hline Agricultural land use \\
\hline Alluvial aquifer \\
\hline Denver aquifer \\
\hline Urban land use \\
\hline Alluvial aquifer \\
\hline Dawson aquifer \\
\hline Bedrock-aquifer well, by aquifer \\
\hline Dawson aquifer \\
\hline Denver aquifer \\
\hline Arapahoe aquifer \\
\hline Laramie-Fox Hills aquifer \\
\hline $\begin{array}{l}\text { Nondetection, shown at the } \\
\text { laboratory reporting level }\end{array}$ \\
\hline
\end{tabular}

C

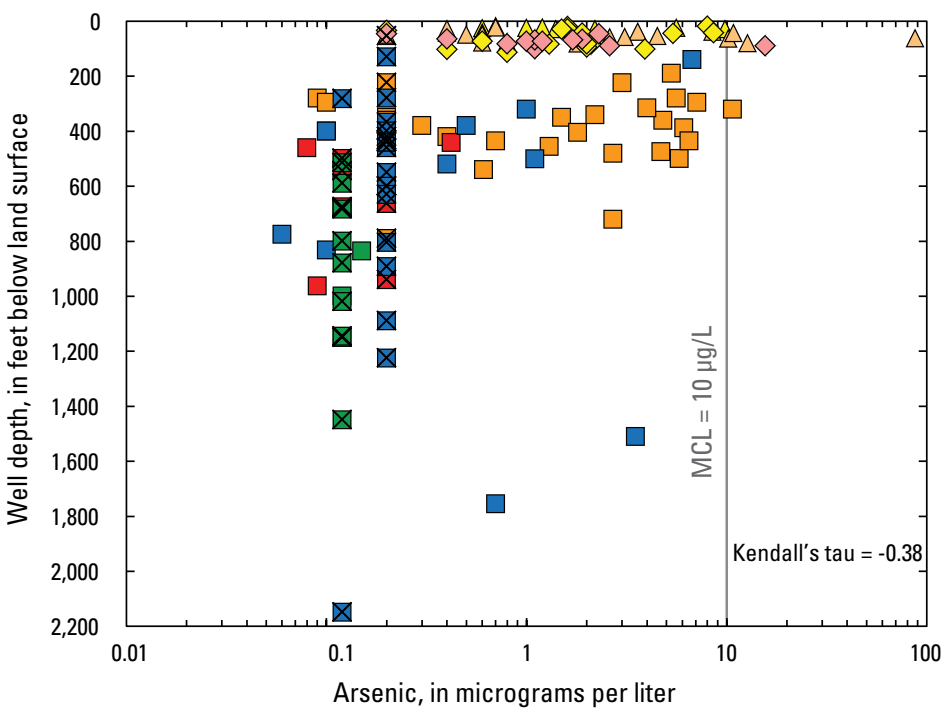

Figure 20. Relation between well depth and concentration for selected trace elements for groundwater samples, Denver Basin aquifer system, Colorado, 2003-5. A, Selenium. $B$, Uranium. C, Arsenic. 


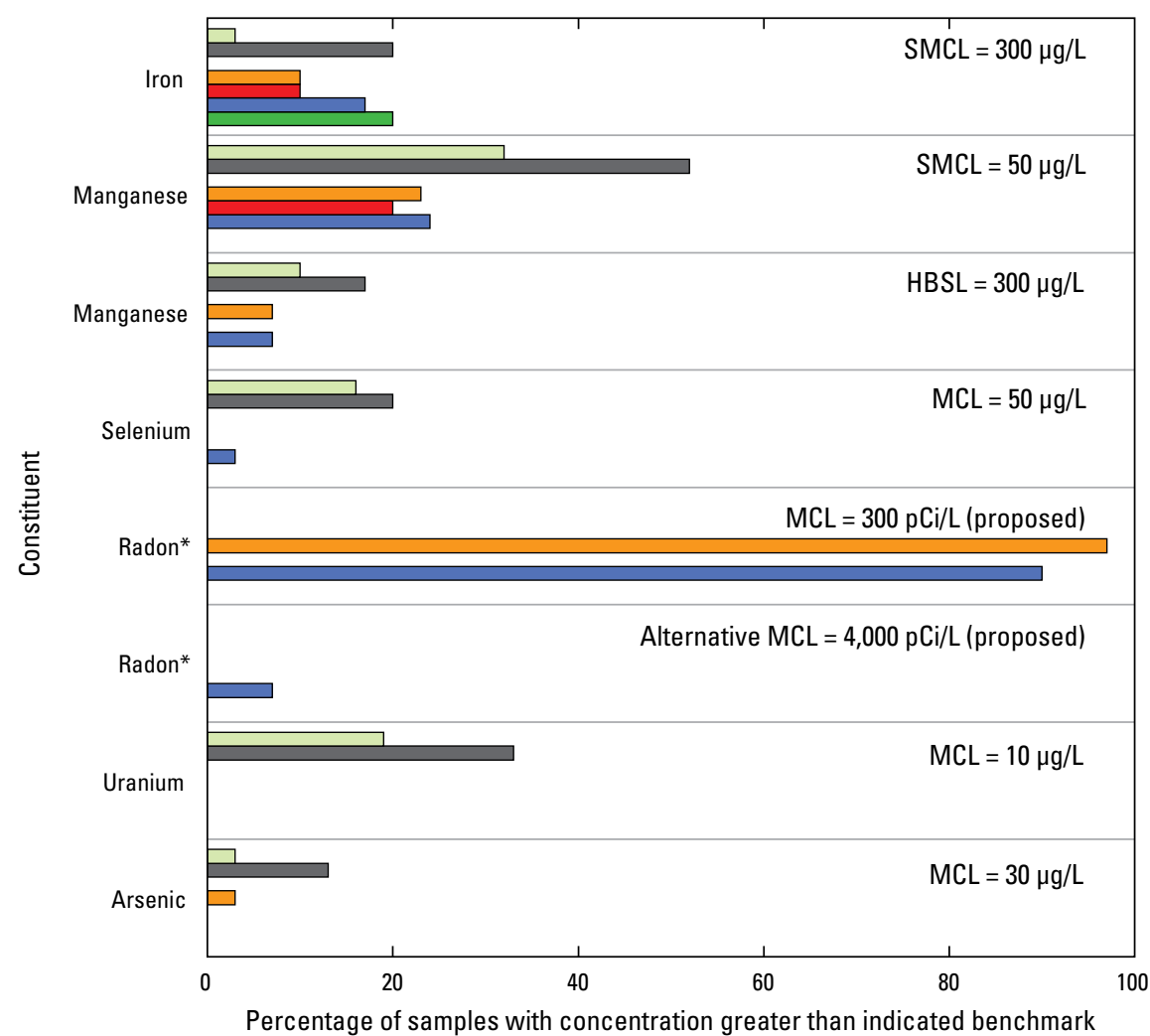

\footnotetext{
EXPLANATION

Water-table well, by land use

$\square \quad$ Agricultural land use

$\square \quad$ Urban land use

Bedrock-aquifer well, by aquifer

$\square \quad$ Dawson aquifer

$\square \quad$ Denver aquifer

$\square \quad$ Arapahoe aquifer

$\square \quad$ Laramie-Fox Hills aquifer

$\mathrm{MCL}$, maximum contaminant level

SMCL, secondary maximum contaminant leve

HBSL, health-based screening level

$\mu \mathrm{g} / \mathrm{L}$, micrograms per liter

$\mathrm{pCi} / \mathrm{L}$, picocuries per liter

*The radon $\mathrm{MCL}$ and alternative $\mathrm{MCL}$ are proposed

levels (U.S. Environmental Protection Agency, 2013).
}

Figure 21. Exceedances of water-quality benchmarks for selected trace elements and radionuclides for groundwater samples, Denver Basin aquifer system, Colorado, 2003-5. 
For the bedrock aquifers, few samples exceeded Se, $\mathrm{U}$, or As MCLs (fig. 21; table 5). Concentrations of Se, U, and As were generally transitional for the Dawson aquifer, the shallowest of the bedrock aquifers, with values between relatively high ranges for the water-table wells and relatively low ranges for the deeper bedrock aquifers (fig. 20; table 5). Median values for these trace elements for the Dawson aquifer were generally at least an order of magnitude higher than median values for the deeper bedrock aquifers (table 5), indicating that the shallowest bedrock aquifer is vulnerable to contamination, likely partially resulting from the downward migration of shallow groundwater. Increased application of irrigation water and associated evaporation in the subsurface have likely mobilized these trace elements from rocks and soils in the unsaturated zone and transported them to the water table. Differences in redox processes and $\mathrm{pH}$ in the deeper bedrock aquifers might also partially control lower concentrations of these trace elements with depth. Se and $\mathrm{U}$ are most soluble in oxic groundwater, and higher median concentrations occur in samples from the water-table wells and Dawson aquifer, which were mostly oxic (table 5).

Elevated Se concentrations in surface water and groundwater in Colorado are widespread, and several studies have correlated Se concentrations with TDS, U, and $\mathrm{NO}_{3}$ concentrations (Weres and others, 1990; Wright, 1999; Gates and others, 2009; Miller and others, 2010; Bailey and others, 2012). Results from the current study are consistent with these previous studies; Se concentrations are positively correlated with TDS, $\mathrm{U}$, and $\mathrm{NO}_{3}$ concentrations (Kendall's tau $=0.38$, 0.61 , and 0.67 , respectively) (fig. 22). Irrigation is believed to be an important factor controlling these concentrations, mobilizing constituents such as $\mathrm{Se}$ and $\mathrm{U}$ present in geologic materials while also adding $\mathrm{NO}_{3}$ from human sources (Zielinski and others, 1995; Seiler and others, 1999). In oxic conditions, $\mathrm{NO}_{3}$ inhibits the reduction of toxic forms of Se and blocks uptake of Se by soils and sediment (Weres and others, 1990; Gates and others, 2009; Bailey and others, 2012). Bicarbonate might also play a role in enhancing the mobility of $U$ in oxic conditions and beneath irrigated areas in the Denver Basin, a process that has been documented in other settings (Ayotte, Gronberg, and others, 2011; Ayotte, Szabo, and others, 2011; Jurgens and others, 2010). In the Denver Basin, $\mathrm{U}$ and $\mathrm{HCO}_{3}$ concentrations were correlated, although the correlation coefficient was relatively low (Kendall's tau = $0.20)$ (fig. 23); the strength of correlation increased (Kendall's tau $=0.39)$ when considering only those samples collected from water-table wells and from the uppermost bedrock aquifer, the Dawson aquifer, where oxic conditions were prevalent.

Rn was measured for bedrock-aquifer samples from only the Dawson and Arapahoe aquifers (table 2). Concentrations were significantly higher for the Dawson aquifer (median $=$ $1,545 \mathrm{pCi} / \mathrm{L}$ ) than for the Arapahoe aquifer (median $=460$ $\mathrm{pCi} / \mathrm{L}$ ) (on the basis of the Mann-Whitney U test) (fig. 24; table 5). In a previous (1993-95) study of the alluvial aquifer in the South Platte River Basin, median Rn concentrations for urban land-use and agricultural land-use areas were 1,100 and $400 \mathrm{pCi} / \mathrm{L}$, respectively (Bruce and McMahon, 1998). High Rn concentrations for samples from the Dawson aquifer, in particular, are likely associated with U-bearing granitic sediments of the Dawson Arkose Formation (table 1). The relation between concentrations of $U$ and $R n$ was significant (Kendall's tau $=0.34$ ), even with potential effects of redox and $\mathrm{pH}$ on the mobility and speciation of $\mathrm{U}$. Rn occurrence is more common in low-pH oxic groundwater, whereas $\mathrm{U}$ occurs more frequently in oxic to mixed redox conditions and generally high-pH conditions (Hem, 1992; Ayotte, Gronberg, and others, 2011). Rn concentrations exceeding the proposed $300 \mathrm{pCi} / \mathrm{L}$ MCL were widespread in both of these bedrock aquifers, but few samples exceeded the proposed alternative MCL of 4,000 pCi/L (fig. 21). One notably high concentration of 25,500 pCi/L (fig. 24) was measured for the Dawson aquifer in Elbert County in the southern part of the Denver Basin.

Iron and $\mathrm{Mn}$ concentrations were highly variable within Denver Basin groundwater (fig. 17; table 5), which might partially reflect local variability in redox conditions and aquifer composition. Exceedances of water-quality benchmarks for $\mathrm{Mn}$ were generally greater for samples from the water-table wells relative to samples from the bedrock aquifers (fig. 21). Exceedances of water-quality benchmarks for Fe were relatively great for the samples from the urban land-use wells and from the deeper bedrock aquifers (fig. 21). An equal number of samples $(n=7)$ from both the watertable wells (6 urban land use and 1 agricultural land use) and the bedrock aquifers (3 Dawson aquifer wells and 4 Arapahoe aquifer wells) exceeded the SMCLs for both $\mathrm{Fe}$ and $\mathrm{Mn}$. Some rocks and minerals of the Denver Basin contain high concentrations of $\mathrm{Mn}$. Both $\mathrm{Fe}$ and $\mathrm{Mn}$ are more likely to dissolve into groundwater in anoxic conditions; correspondingly, $\mathrm{Fe}$ and $\mathrm{Mn}$ concentrations for Denver Basin groundwater are higher in anoxic conditions than in oxic conditions (fig. 25). 
$\boldsymbol{A}$

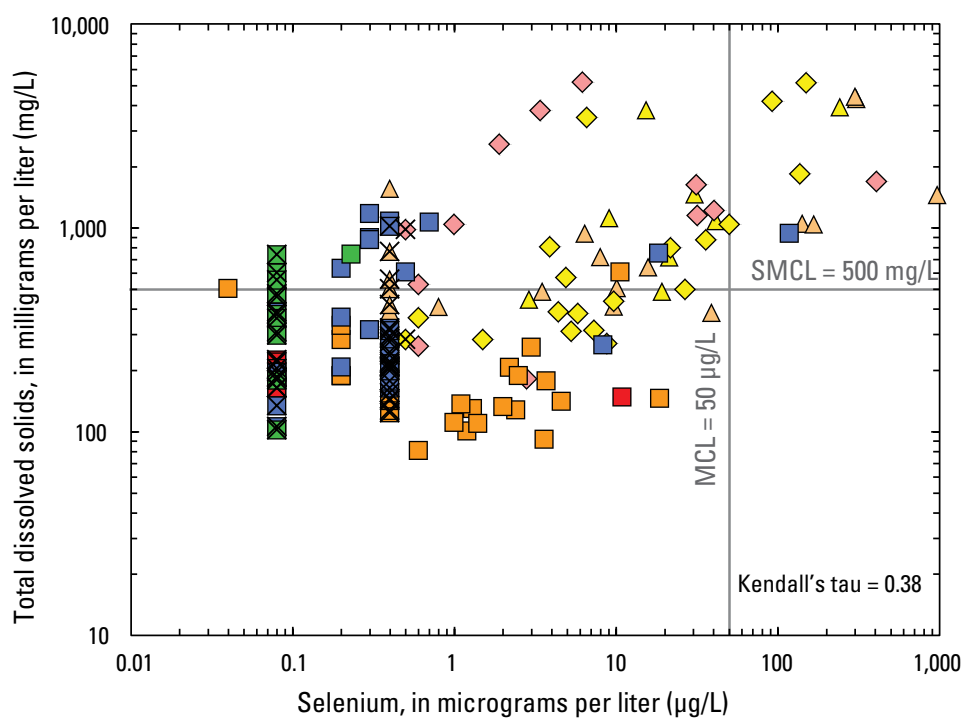

B

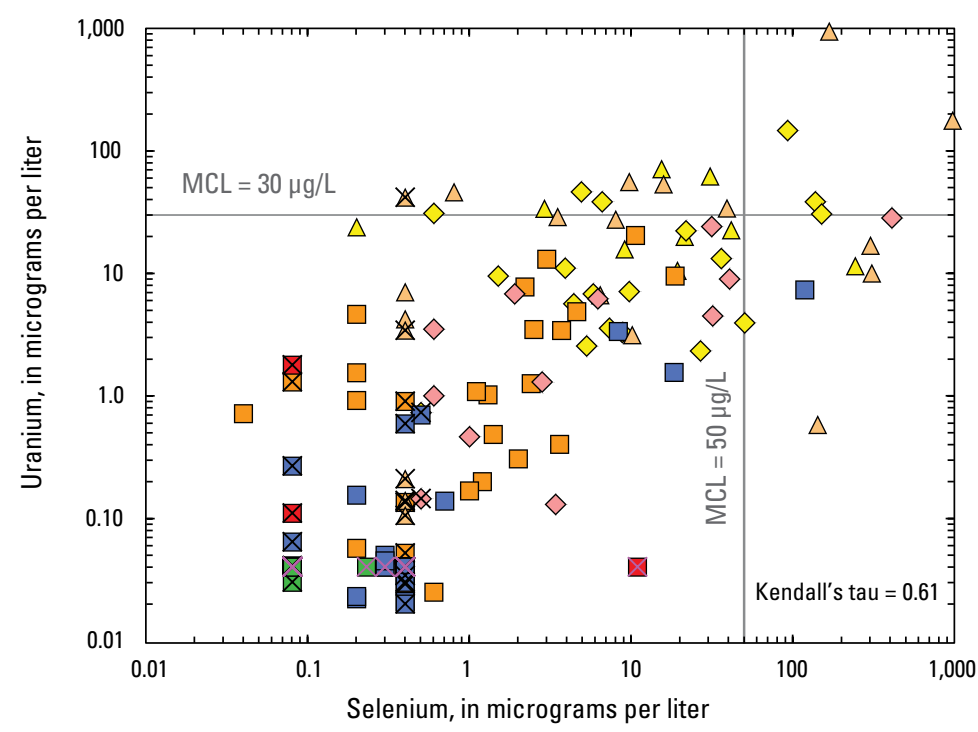

C

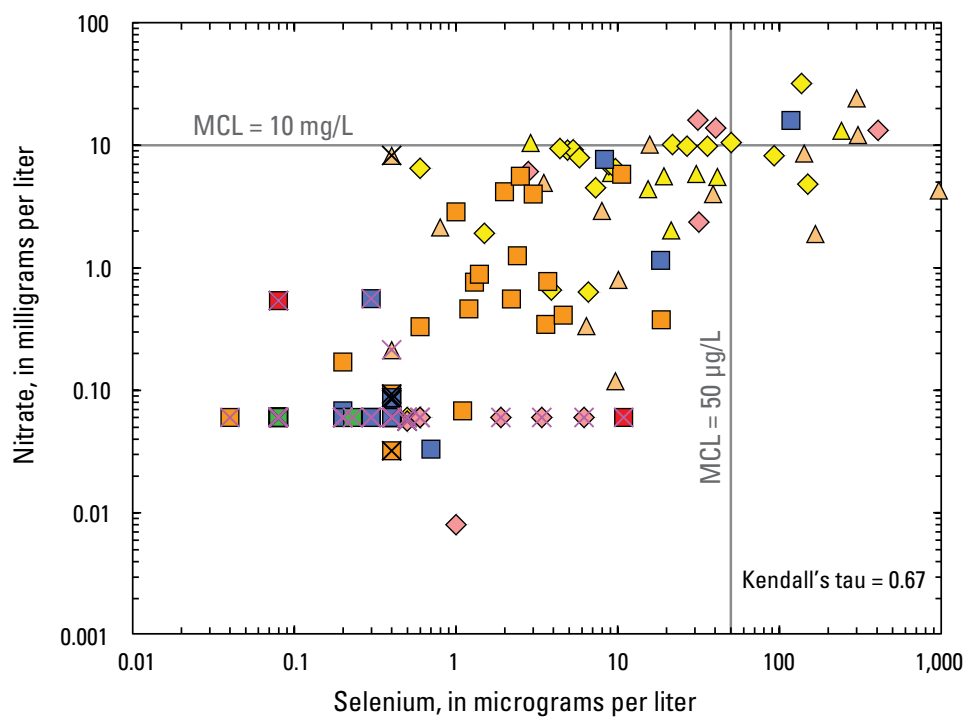

EXPLANATION

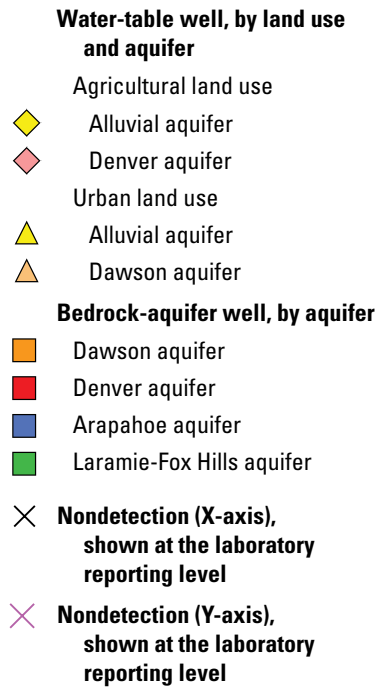

MCL, maximum contaminant level SMCL, secondary maximum contaminant level

Figure 22. Relation between selenium and selected geochemical constituent concentrations for groundwater samples, Denver Basin aquifer system, Colorado, 2003-5. A, Total dissolved solids. B, Uranium. $C$, Nitrate. 


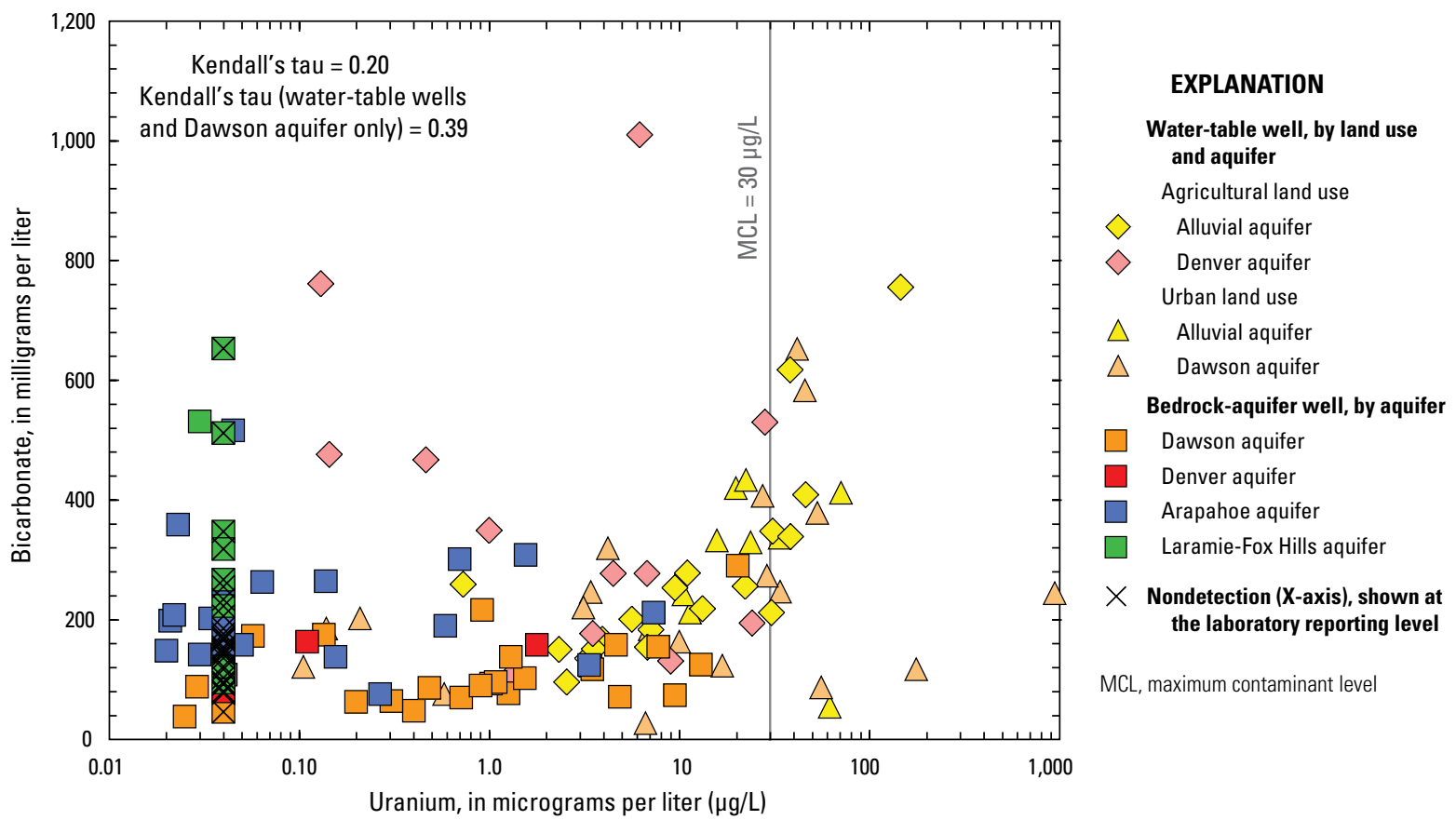

Figure 23. Relation between uranium and bicarbonate concentrations for groundwater samples, Denver Basin aquifer system, Colorado, 2003-5.

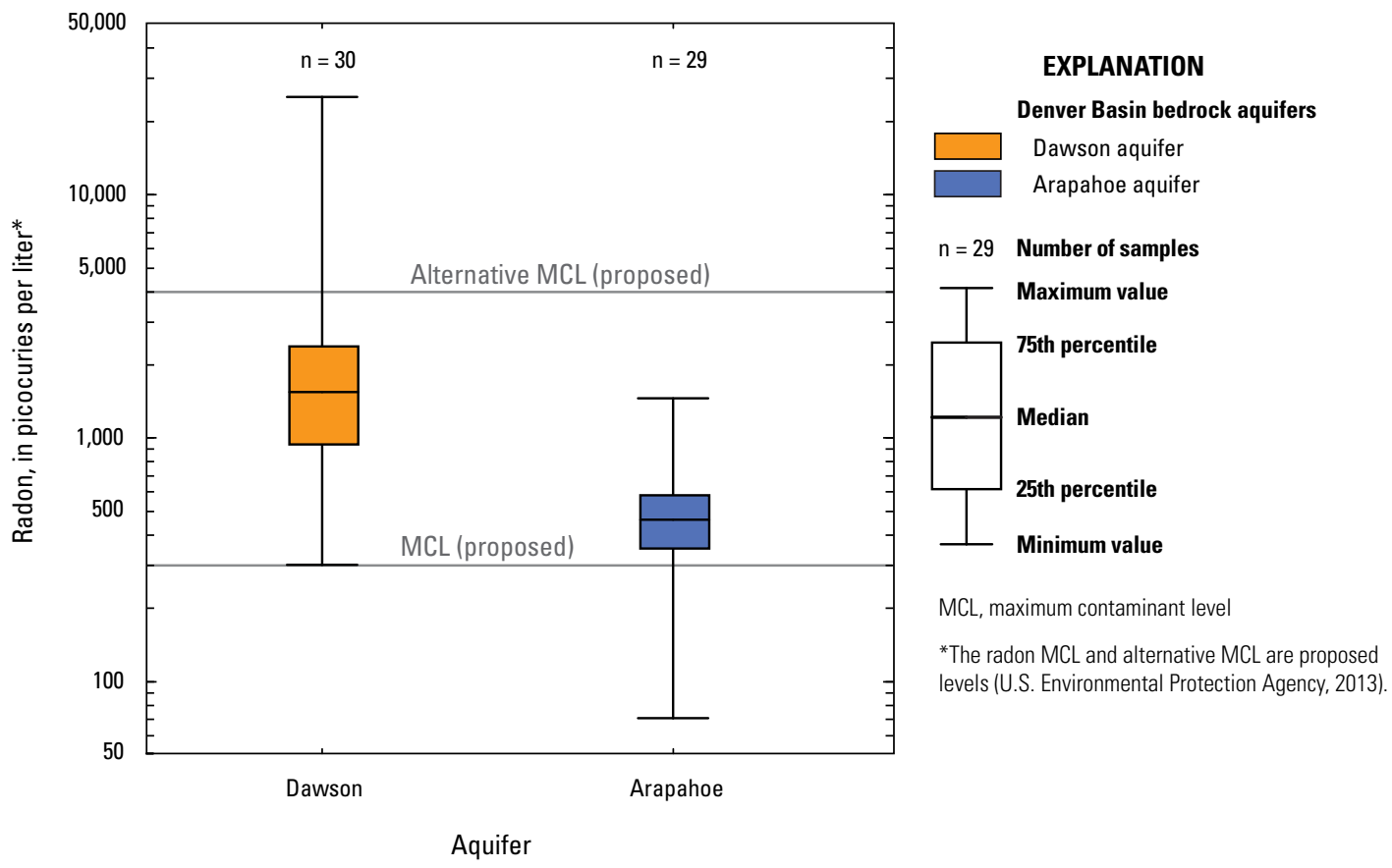

Figure 24. Distribution of radon concentration for groundwater samples, Denver Basin aquifer system, Colorado, 2003-5. 
A

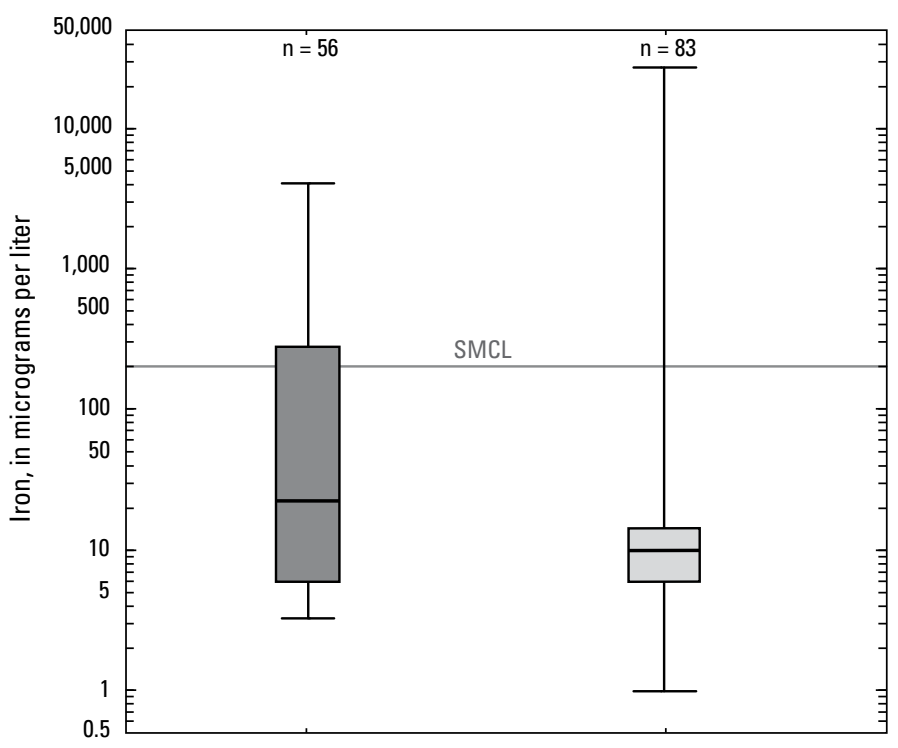

EXPLANATION

Anoxic-Dissolved oxygen (DO) less than $(<)$ 0.5 milligrams per liter ( $\mathrm{mg} / \mathrm{L}$ )

0xic-D0 greater than or equal to $(\geq) 0.5 \mathrm{mg} / \mathrm{L}$

$\mathrm{n}=56$ Number of samples

T Maximum value

75th percentile

Median

25th percentile

$\perp$ Minimum value

SMCL, secondary maximum contaminant level HBSL, health-based screening level

\section{B}

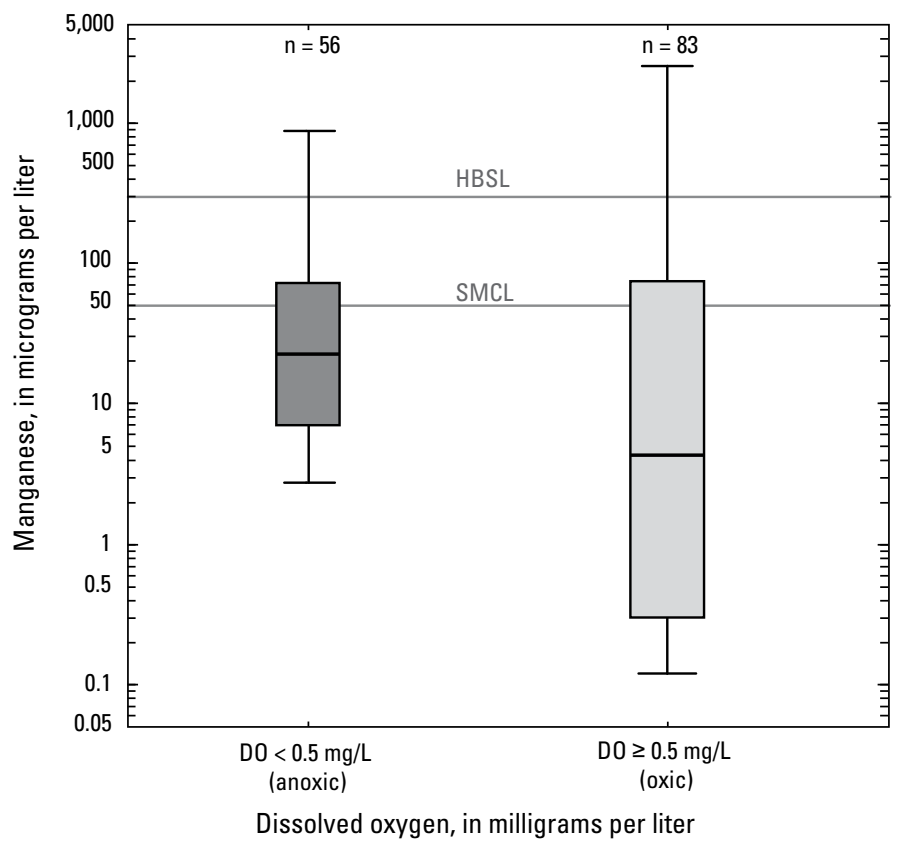

Figure 25. Distribution of iron and manganese concentrations for anoxic and oxic conditions for groundwater samples, Denver Basin, Colorado, 2003-5. 


\section{Organic Compounds}

Organic compounds such as pesticides and VOCs generally do not occur naturally in hydrologic systems; their presence results from human activities (Hem, 1992). The occurrence of these organic compounds in groundwater and drinking-water sources is indicative of human contamination and is of concern because of their toxic and carcinogenic properties and related potential detrimental effects on human and ecosystem health. Many pesticides and VOCs are relatively soluble and thus can be transported in groundwater if human sources have made them available for transport to the subsurface. The frequency of detection and distribution of organic contaminants both spatially and with depth provide insight regarding potential sources to and pathways in groundwater and whether or not Denver Basin aquifers are vulnerable to the effects of human activities. Pesticides and their degradation products include toxic compounds used to kill or control plants (herbicides), insects (insecticides), fungi (fungicides), rodents (rodenticides), or other organisms (Gilliom and others, 2006). VOCs are carbon-based compounds that readily volatilize and include compounds found in organic solvents, fuels, refrigerants, and fumigants; VOCs also include trihalomethane compounds, which are byproducts created by the disinfection of drinking water by chlorination (Zogorski and others, 2006). Because detections of organic compounds were relatively infrequent and measured concentrations were often close to detection levels, the count of the number of organic compounds detected in a sample (detection frequency) is considered in this analysis in addition to concentrations.

Pesticide compounds and VOCs were analyzed in selected samples collected from water-table wells (VOCs were not analyzed in agricultural land-use wells) and from the Dawson and Arapahoe bedrock aquifers (the Denver and Laramie-Fox Hills samples were not analyzed for pesticide compounds and VOCs) (table 9). A total of 8 pesticide and 17 VOC compounds were detected, all at concentrations that were generally orders of magnitude less than applicable benchmarks or standards (table 9). Pesticides and VOCs were more frequently detected in samples collected from watertable wells than from the bedrock aquifers, and the number of compounds detected generally decreased with well depth (fig. 26; table 9). One or more pesticide or pesticide degradate compounds were detected in 33 percent of the water-table well samples. Most of the same compounds were detected in samples from either the agricultural or urban land-use wells. The most frequently detected pesticides for the watertable wells were atrazine, its degradate deethylatrazine, and prometon (fig. 27). Prometon was more frequently detected in samples from urban land-use wells than in those from agricultural land-use wells. One or more VOCs were detected in 62 percent of samples from the urban land-use wells; more than half of these samples had detections of more than one VOC. VOC detections for samples from the urban landuse wells were dominated by chloroform; other frequently detected VOCs were bromodichloromethane, PCE, and carbon disulfide (fig. 27; table 9). The relatively high frequency of chloroform detections in samples from the water-table wells indicates that this constituent is widely distributed throughout the alluvial aquifer. The frequent detection of chloroform at low concentrations is consistent with shallow groundwater in many aquifers across the Nation (Zogorski and others, 2006). Human sources of chloroform include drinking-water treatment processes, leaking water and wastewater lines, septic systems, and recharge from irrigation with treated wastewater (so called gray water); biomass burning and soil microorganisms are natural sources of chloroform (Ivahnenko and Barbash, 2004). Sorption to organic carbon present in alluvial sediments might decrease the rate at which VOCs are transported to the water table. Storm events that flush contaminants from the land surface also might increase the transport of organic compounds to the water table.

The relatively common detection of several pesticides and VOCs in samples from the water-table wells is indicative of relatively young groundwater and of the vulnerability of shallow groundwater in the Denver Basin to contamination from human sources. These results are consistent with a previous study (1993-95) that documented pesticides and VOCs in the alluvial aquifer in the South Platte River Basin (Bruce and McMahon, 1998); many of the same pesticide compounds were commonly detected (specifically atrazine, deethylatrazine, and prometon), with atrazine and deethylatrazine detections much more frequent for samples collected from beneath agricultural areas relative to those collected from urban areas (Bruce and McMahon, 1998). The frequency of detection of pesticide compounds for shallow groundwater from the current urban land-use areas consisting of relatively new suburban areas in the south Denver metropolitan area was compared with results for the older urban core of Denver sampled in the previous study (Bruce and McMahon, 1998); results were similar for atrazine (17 and 23 percent, respectively) and deethylatrazine (10 and 7 percent, respectively), but detections were less frequent for prometon in the current study relative to the previous study (31 and 80 percent, respectively). In the previous study, VOC detections in samples from urban land-use wells were dominated by MTBE, which was detected in 79 percent of samples (Bruce and McMahon, 1998). Although the same wells were not sampled in the current study (and thus direct comparison of results is not possible), MTBE was detected in only one sample ( 3 percent) from the urban land-use wells in the current study. The apparent decrease in MTBE detections for urban areas might partially result from a statewide ban of MTBE use implemented in 2002 (U.S. Environmental Protection Agency, 2004b). Overall, fewer VOCs $(n=10)$ were detected in the current study for shallow groundwater in urban areas than in the previous study $(\mathrm{n}=31)$ (Bruce and McMahon, 1998). In the previous study, VOCs were measured for samples from agricultural areas in the South Platte River; none were detected (Bruce and McMahon, 1998), and VOCs were not measured in the current study for samples from agricultural areas. 
Table 9. Summary statistics for groundwater samples with detections of selected pesticide compounds and volatile organic compounds, Denver Basin aquifer system, Colorado, 2003-5.

[HBSL, health-based screening level (benchmark); MCL, maximum contaminant level (standard); na, not applicable because there is no benchmark or standard; <, less than; --, not analyzed; E, estimated; $\mu \mathrm{g} / \mathrm{L}$, micrograms per liter; values in bold are detections]

\begin{tabular}{|c|c|c|c|c|c|c|c|c|c|c|c|}
\hline \multirow{3}{*}{$\begin{array}{l}\text { Constituent } \\
\text { group }\end{array}$} & \multirow{3}{*}{$\begin{array}{l}\text { Constituent } \\
\text { subgroup }\end{array}$} & \multirow[b]{3}{*}{ Constituent } & \multirow[b]{3}{*}{ Unit } & \multirow{2}{*}{\multicolumn{2}{|c|}{$\begin{array}{l}\text { Benchmark } \\
\text { or standard }\end{array}$}} & \multicolumn{6}{|c|}{ Water-table wells } \\
\hline & & & & & & \multicolumn{3}{|c|}{$\begin{array}{l}\text { Agricultural land use } \\
(\mathrm{n}=31)\end{array}$} & \multicolumn{3}{|c|}{$\begin{array}{l}\text { Urban land use } \\
\qquad(n=29)\end{array}$} \\
\hline & & & & Type $^{1}$ & Value & $\begin{array}{l}\text { Maximum } \\
\text { concentra- } \\
\text { tion, where } \\
\text { detected }\end{array}$ & $\begin{array}{l}\text { Num- } \\
\text { ber of } \\
\text { detec- } \\
\text { tions }\end{array}$ & $\begin{array}{l}\text { Frequency } \\
\text { of detec- } \\
\text { tions } \\
\text { (percent) }\end{array}$ & $\begin{array}{l}\text { Maximum } \\
\text { concentra- } \\
\text { tion }\end{array}$ & $\begin{array}{l}\text { Num- } \\
\text { ber of } \\
\text { detec- } \\
\text { tions }\end{array}$ & $\begin{array}{c}\text { Frequency } \\
\text { of detec- } \\
\text { tions } \\
\text { (percent) }\end{array}$ \\
\hline \multirow{8}{*}{$\begin{array}{l}\text { Pesticides and } \\
\text { pesticide deg- } \\
\text { radates }\end{array}$} & & Acetochlor & $\mu \mathrm{g} / \mathrm{L}$ & HBSL (low, high) & $10 ; 10$ & $<0.006$ & 0 & 0 & $<0.006$ & 0 & 0 \\
\hline & & Atrazine & $\mu \mathrm{g} / \mathrm{L}$ & MCL & 3 & 0.133 & 6 & 19 & E0.006 & 5 & 17 \\
\hline & & Deethylatrazine & $\mu \mathrm{g} / \mathrm{L}$ & na & na & E0.108 & 4 & 13 & E0.004 & 3 & 10 \\
\hline & & Metolachlor & $\mu \mathrm{g} / \mathrm{L}$ & HBSL (low, high) & $700 ; 700$ & $<0.013$ & 0 & 0 & E0.007 & 1 & 3 \\
\hline & & Metribuzin & $\mu \mathrm{g} / \mathrm{L}$ & HBSL (low, high) & $90 ; 90$ & $<0.006$ & 0 & 0 & $<0.006$ & 0 & 0 \\
\hline & & Prometon & $\mu \mathrm{g} / \mathrm{L}$ & HBSL (low, high) & $400 ; 400$ & E0.003 & 1 & 3 & 0.095 & 9 & 31 \\
\hline & & Simazine & $\mu \mathrm{g} / \mathrm{L}$ & MCL & 4 & $<0.005$ & 0 & 0 & 0.007 & 1 & 3 \\
\hline & & Terbuthylazine & $\mu \mathrm{g} / \mathrm{L}$ & HBSL (low, high) & $2 ; 2$ & -- & -- & -- & -- & -- & -- \\
\hline \multirow{17}{*}{$\begin{array}{l}\text { Volatile organic } \\
\text { compounds } \\
\text { (VOCs) }\end{array}$} & \multirow{5}{*}{ Solvents } & Trichloroethene & $\mu \mathrm{g} / \mathrm{L}$ & MCL & 5 & -- & -- & -- & E0.052 & 1 & 3 \\
\hline & & Tetrachloroethene (PCE) & $\mu \mathrm{g} / \mathrm{L}$ & MCL & 5 & -- & -- & -- & E0.058 & 4 & 14 \\
\hline & & 1,1,1-Trichloroethane & $\mu \mathrm{g} / \mathrm{L}$ & MCL & 200 & -- & -- & -- & E0.032 & 1 & 3 \\
\hline & & 1,1-Dichloroethane & $\mu \mathrm{g} / \mathrm{L}$ & na & na & -- & -- & -- & E0.039 & 1 & 3 \\
\hline & & Dichlorodifluoromethane & $\mu \mathrm{g} / \mathrm{L}$ & HBSL (low, high) & 1,$000 ; 1,000$ & -- & -- & -- & $<0.18$ & 0 & 0 \\
\hline & \multirow{4}{*}{$\begin{array}{l}\text { Fuel com- } \\
\text { pounds }\end{array}$} & Benzene & $\mu \mathrm{g} / \mathrm{L}$ & MCL & 5 & -- & -- & -- & $<0.02$ & 0 & 0 \\
\hline & & Toluene & $\mu \mathrm{g} / \mathrm{L}$ & MCL & 1,000 & -- & -- & -- & $<0.05$ & 0 & 0 \\
\hline & & Methyl tert-butyl ether (MTBE) & $\mu \mathrm{g} / \mathrm{L}$ & na & na & -- & -- & -- & 0.22 & 2 & 7 \\
\hline & & Isopropylbenzene & $\mu \mathrm{g} / \mathrm{L}$ & HBSL (low, high) & $700 ; 700$ & -- & -- & -- & $<0.04$ & 0 & 0 \\
\hline & \multirow{4}{*}{$\begin{array}{l}\text { Trihalo- } \\
\text { methanes } \\
(\mathrm{THMs})^{2}\end{array}$} & Trichloromethane (chloroform) & $\mu \mathrm{g} / \mathrm{L}$ & $\mathrm{MCL}^{2}$ & ${ }^{2} 80$ & -- & -- & -- & 0.751 & 13 & 45 \\
\hline & & Bromodichloromethane & $\mu \mathrm{g} / \mathrm{L}$ & $\mathrm{MCL}^{2}$ & ${ }^{2} 80$ & -- & -- & -- & 0.534 & 5 & 17 \\
\hline & & Dibromochloromethane & $\mu \mathrm{g} / \mathrm{L}$ & $\mathrm{MCL}^{2}$ & ${ }^{2} 80$ & -- & -- & -- & 0.32 & 1 & 3 \\
\hline & & Dichloromethane & $\mu \mathrm{g} / \mathrm{L}$ & MCL & 5 & -- & -- & -- & E0.08 & 2 & 7 \\
\hline & \multirow{4}{*}{ Other } & 1,2,4-Trimethylbenzene & $\mu \mathrm{g} / \mathrm{L}$ & na & na & -- & -- & -- & $<0.06$ & 0 & 0 \\
\hline & & 2-Chlorotoluene & $\mu \mathrm{g} / \mathrm{L}$ & na & na & -- & -- & -- & $<0.04$ & 0 & 0 \\
\hline & & Carbon disulfide & $\mu \mathrm{g} / \mathrm{L}$ & HBSL (low, high) & $700 ; 700$ & -- & -- & -- & 0.2 & 4 & 14 \\
\hline & & Styrene & $\mu \mathrm{g} / \mathrm{L}$ & MCL & 100 & -- & -- & -- & $<0.04$ & 0 & 0 \\
\hline
\end{tabular}


Table 9. Summary statistics for groundwater samples with detections of selected pesticide compounds and volatile organic compounds, Denver Basin aquifer system, Colorado, 2003-5.-Continued

[HBSL, health-based screening level (benchmark); MCL, maximum contaminant level (standard); na, not applicable because there is no benchmark or standard; <, less than; --, not analyzed; E, estimated; $\mu \mathrm{g} / \mathrm{L}$, micrograms per liter; values in bold are detections]

\begin{tabular}{|c|c|c|c|c|c|c|c|c|c|c|c|}
\hline \multirow{3}{*}{$\begin{array}{l}\text { Constituent } \\
\text { group }\end{array}$} & \multirow{3}{*}{$\begin{array}{l}\text { Constituent } \\
\text { subgroup }\end{array}$} & \multirow[b]{3}{*}{ Constituent } & \multirow[b]{3}{*}{ Unit } & \multirow{2}{*}{\multicolumn{2}{|c|}{$\begin{array}{l}\text { Benchmark } \\
\text { or standard }\end{array}$}} & \multicolumn{6}{|c|}{ Bedrock aquifers } \\
\hline & & & & & & \multicolumn{3}{|c|}{$\begin{array}{l}\text { Dawson aquifer } \\
(n=30)\end{array}$} & \multicolumn{3}{|c|}{$\begin{array}{c}\text { Arapahoe aquifer } \\
(n=29)\end{array}$} \\
\hline & & & & Type $^{1}$ & Value & $\begin{array}{l}\text { Maximum } \\
\text { concentra- } \\
\text { tion }\end{array}$ & $\begin{array}{l}\text { Num- } \\
\text { ber of } \\
\text { detec- } \\
\text { tions }\end{array}$ & $\begin{array}{l}\text { Frequency } \\
\text { of detec- } \\
\text { tions } \\
\text { (percent) }\end{array}$ & $\begin{array}{l}\text { Maximum } \\
\text { concentra- } \\
\text { tion }\end{array}$ & $\begin{array}{c}\text { Num- } \\
\text { ber of } \\
\text { detec- } \\
\text { tions }\end{array}$ & $\begin{array}{c}\text { Frequency } \\
\text { of detec- } \\
\text { tions } \\
\text { (percent) }\end{array}$ \\
\hline \multirow{8}{*}{$\begin{array}{l}\text { Pesticides and } \\
\text { pesticide deg- } \\
\text { radates }\end{array}$} & & Acetochlor & $\mu \mathrm{g} / \mathrm{L}$ & HBSL (low, high) & $10 ; 10$ & E0.016 & 1 & 3 & $<0.006$ & 0 & 0 \\
\hline & & Atrazine & $\mu \mathrm{g} / \mathrm{L}$ & MCL & 3 & 0.07 & 2 & 7 & $<0.007$ & 0 & 0 \\
\hline & & Deethylatrazine & $\mu \mathrm{g} / \mathrm{L}$ & na & na & E0.05 & 2 & 7 & $<0.006$ & 0 & 0 \\
\hline & & Metolachlor & $\mu \mathrm{g} / \mathrm{L}$ & HBSL (low, high) & $700 ; 700$ & 0.048 & 2 & 7 & $<0.006$ & 0 & 0 \\
\hline & & Metribuzin & $\mu \mathrm{g} / \mathrm{L}$ & HBSL (low, high) & $90 ; 90$ & 0.025 & 1 & 3 & $<0.006$ & 0 & 0 \\
\hline & & Prometon & $\mu \mathrm{g} / \mathrm{L}$ & HBSL (low, high) & $400 ; 400$ & E0.009 & 2 & 7 & $<0.01$ & 0 & 0 \\
\hline & & Simazine & $\mu \mathrm{g} / \mathrm{L}$ & MCL & 4 & 0.020 & 2 & 7 & $<0.005$ & 0 & 0 \\
\hline & & Terbuthylazine & $\mu \mathrm{g} / \mathrm{L}$ & HBSL (low, high) & $2 ; 2$ & E0.009 & 1 & 3 & $<0.0102$ & 0 & 0 \\
\hline \multirow{17}{*}{$\begin{array}{l}\text { Volatile organic } \\
\text { compounds } \\
\text { (VOCs) }\end{array}$} & \multirow{5}{*}{ Solvents } & Trichloroethene & $\mu \mathrm{g} / \mathrm{L}$ & MCL & 5 & $<0.04$ & 0 & 0 & $<0.04$ & 0 & 0 \\
\hline & & Tetrachloroethene (PCE) & $\mu \mathrm{g} / \mathrm{L}$ & MCL & 5 & $<0.03$ & 0 & 0 & $<0.03$ & 0 & 0 \\
\hline & & 1,1,1-Trichloroethane & $\mu \mathrm{g} / \mathrm{L}$ & MCL & 200 & $<0.03$ & 0 & 0 & $<0.03$ & 0 & 0 \\
\hline & & 1,1-Dichloroethane & $\mu \mathrm{g} / \mathrm{L}$ & na & na & $<0.04$ & 0 & 0 & $<0.04$ & 0 & 0 \\
\hline & & Dichlorodifluoromethane & $\mu \mathrm{g} / \mathrm{L}$ & HBSL (low, high) & 1,$000 ; 1,000$ & E0.6 & 1 & 3 & E0.05 & 1 & 3 \\
\hline & \multirow{4}{*}{$\begin{array}{c}\text { Fuel com- } \\
\text { pounds }\end{array}$} & Benzene & $\mu \mathrm{g} / \mathrm{L}$ & MCL & 5 & $<0.02$ & 0 & 0 & E0.03 & 1 & 3 \\
\hline & & Toluene & $\mu \mathrm{g} / \mathrm{L}$ & MCL & 1,000 & $<0.02$ & 0 & 0 & 0.303 & 1 & 3 \\
\hline & & Methyl tert-butyl ether (MTBE) & $\mu \mathrm{g} / \mathrm{L}$ & na & na & $<0.1$ & 0 & 0 & $<0.1$ & 0 & 0 \\
\hline & & Isopropylbenzene & $\mu \mathrm{g} / \mathrm{L}$ & HBSL (low, high) & $700 ; 700$ & $<0.04$ & 0 & 0 & E0.037 & 1 & 3 \\
\hline & \multirow{4}{*}{$\begin{array}{l}\text { Trihalo- } \\
\text { methanes } \\
(\mathrm{THMs})^{2}\end{array}$} & Trichloromethane (chloroform) & $\mu \mathrm{g} / \mathrm{L}$ & $\mathrm{MCL}^{2}$ & ${ }^{2} 80$ & $<0.024$ & 0 & 0 & 9.38 & 2 & 7 \\
\hline & & Bromodichloromethane & $\mu \mathrm{g} / \mathrm{L}$ & $\mathrm{MCL}^{2}$ & ${ }^{2} 80$ & $<0.03$ & 0 & 0 & 0.159 & 1 & 3 \\
\hline & & Dibromochloromethane & $\mu \mathrm{g} / \mathrm{L}$ & $\mathrm{MCL}^{2}$ & ${ }^{2} 80$ & $<0.1$ & 0 & 0 & $<0.1$ & 0 & 0 \\
\hline & & Dichloromethane & $\mu \mathrm{g} / \mathrm{L}$ & MCL & 5 & $<0.06$ & 0 & 0 & 0.05 & 1 & 3 \\
\hline & \multirow{4}{*}{ Other } & 1,2,4-Trimethylbenzene & $\mu \mathrm{g} / \mathrm{L}$ & na & na & $<0.06$ & 0 & 0 & E0.054 & 1 & 3 \\
\hline & & 2-Chlorotoluene & $\mu \mathrm{g} / \mathrm{L}$ & na & na & $<0.04$ & 0 & 0 & E0.014 & 1 & 3 \\
\hline & & Carbon disulfide & $\mu \mathrm{g} / \mathrm{L}$ & HBSL (low, high) & $700 ; 700$ & $<0.04$ & 0 & 0 & E0.09 & 5 & 17 \\
\hline & & Styrene & $\mu \mathrm{g} / \mathrm{L}$ & MCL & 100 & $<0.04$ & 0 & 0 & E0.021 & 1 & 3 \\
\hline
\end{tabular}

${ }^{1}$ HBSL ranges (low, high) represent the contaminant concentration in drinking water that corresponds to an excess estimated lifetime cancer risk of 1 chance in 1 million to 1 chance in 10 thousand (Toccalino and others, 2004).

${ }^{2} \mathrm{MCL}$ for total $\mathrm{THMs}=80 \mu \mathrm{g} / \mathrm{L}$. 
$\boldsymbol{A}$

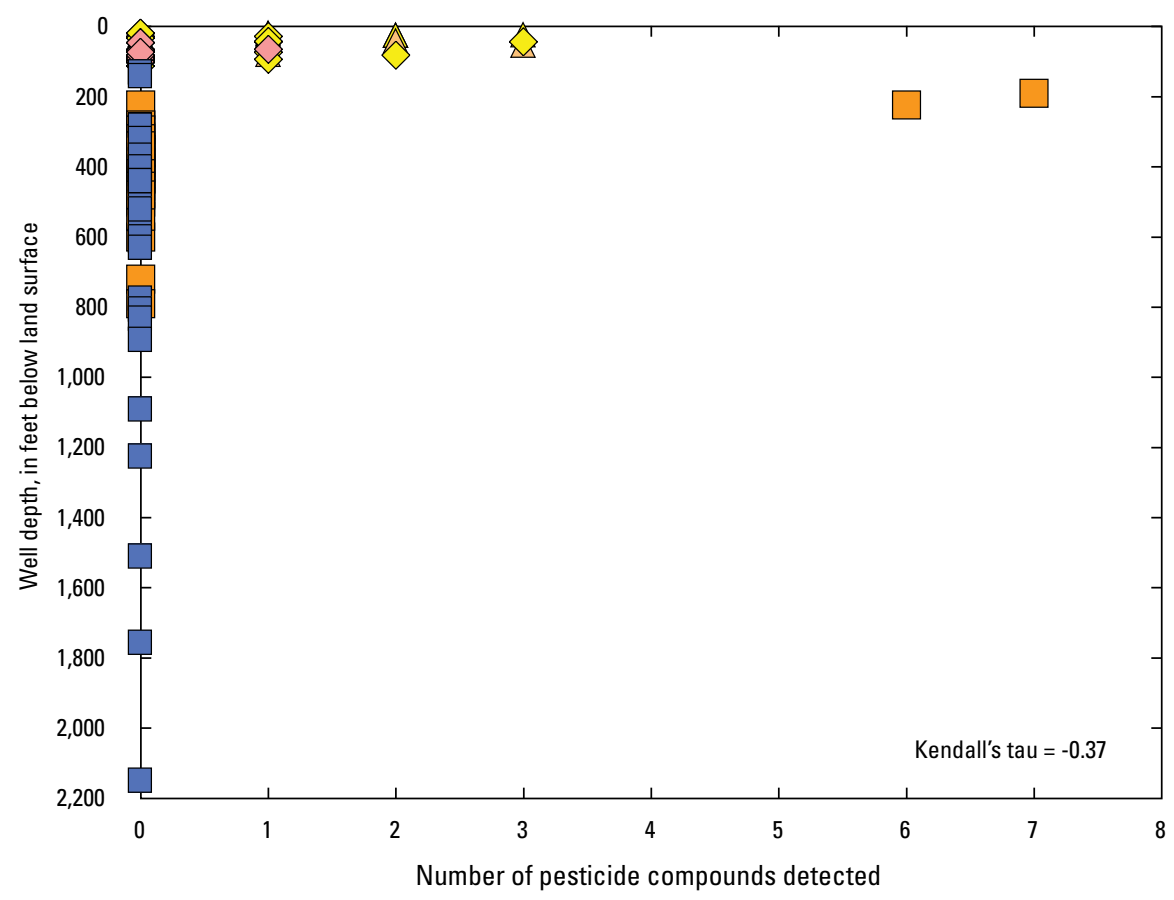

$\boldsymbol{B}$

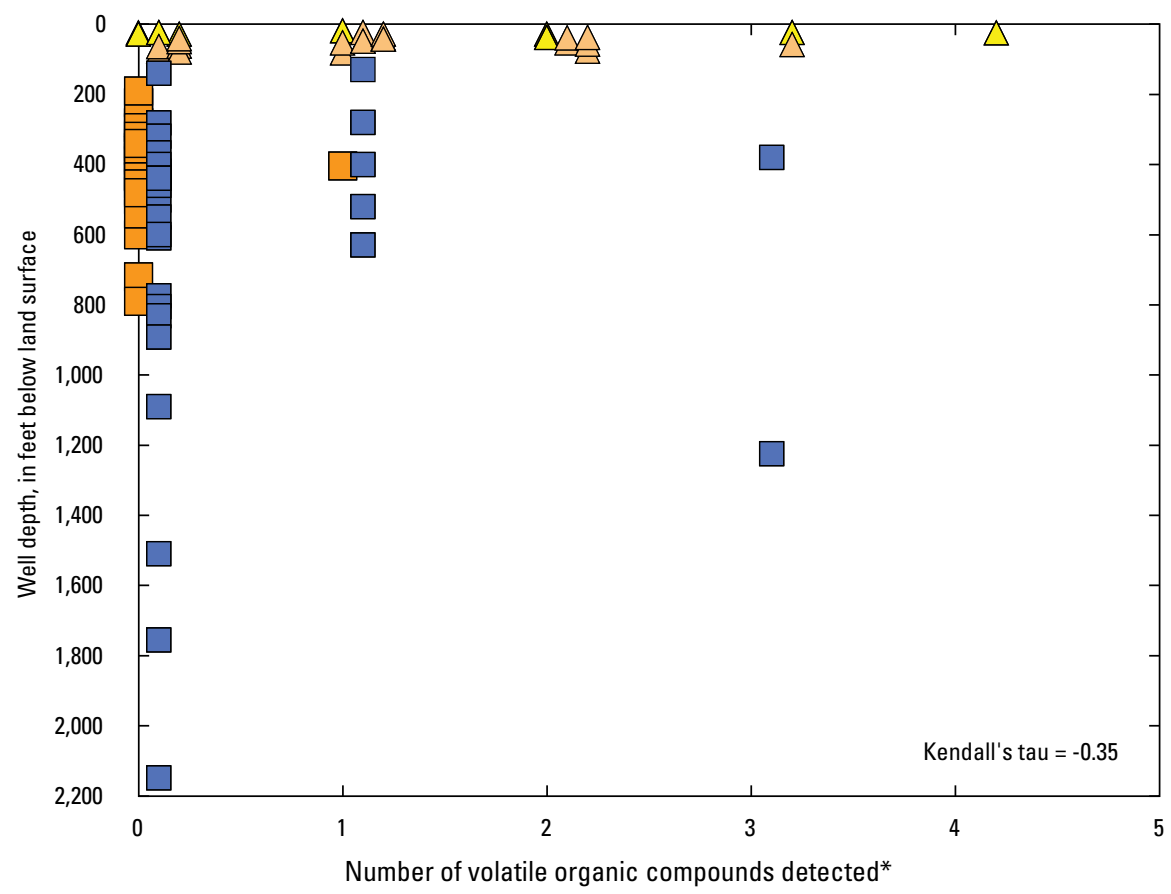

\section{EXPLANATION}

Water-table well, by land use and aquifer

Agricultural land use

$\diamond \quad$ Alluvial aquifer

$\diamond$ Denver aquifer

Urban land use

$\triangle \quad$ Alluvial aquifer

$\triangle \quad$ Dawson aquifer Bedrock-aquifer well, by aquifer

Dawson aquifer

Arapahoe aquifer

*Carbon disulfide detections not included for samples from the bedrock aquifers.

Figure 26. Relation between well depth and the number of organic compounds detected for groundwater samples, Denver Basin aquifer system, Colorado, 2003-5. A, Pesticide compounds. $B$, Volatile organic compounds. 


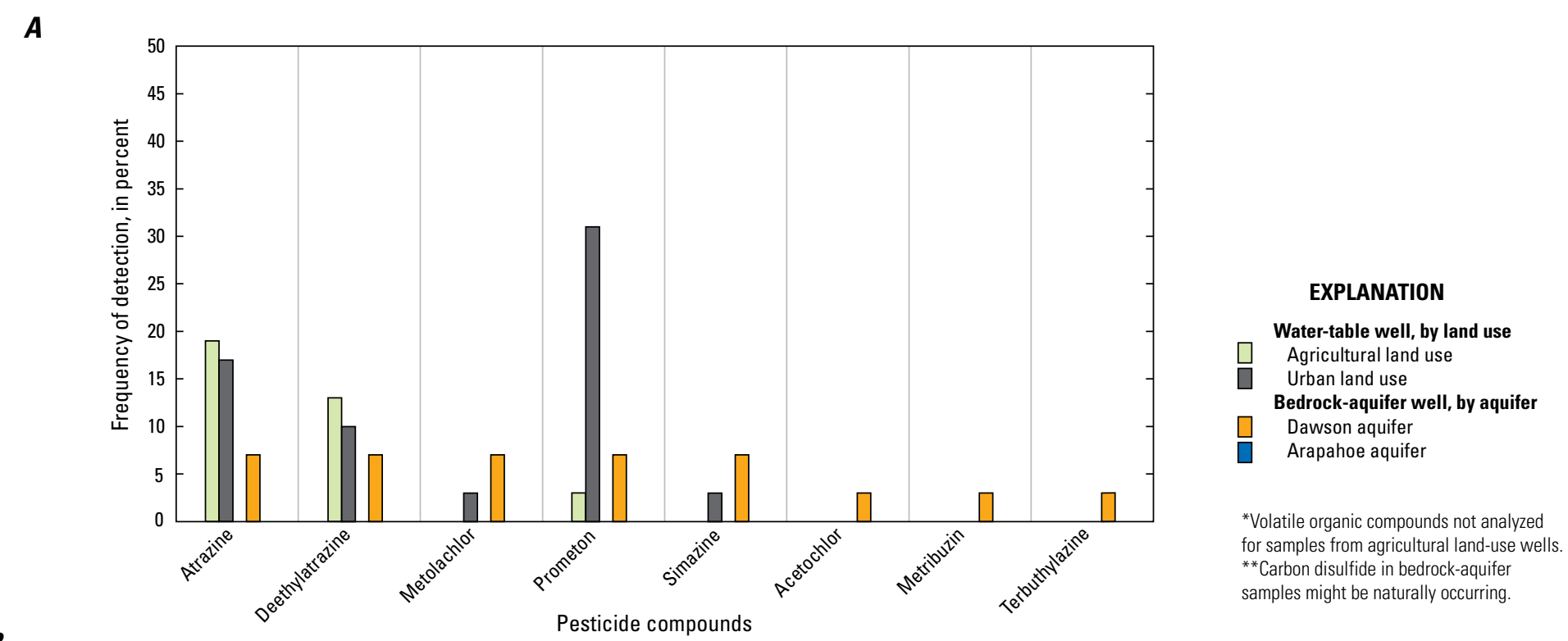

B

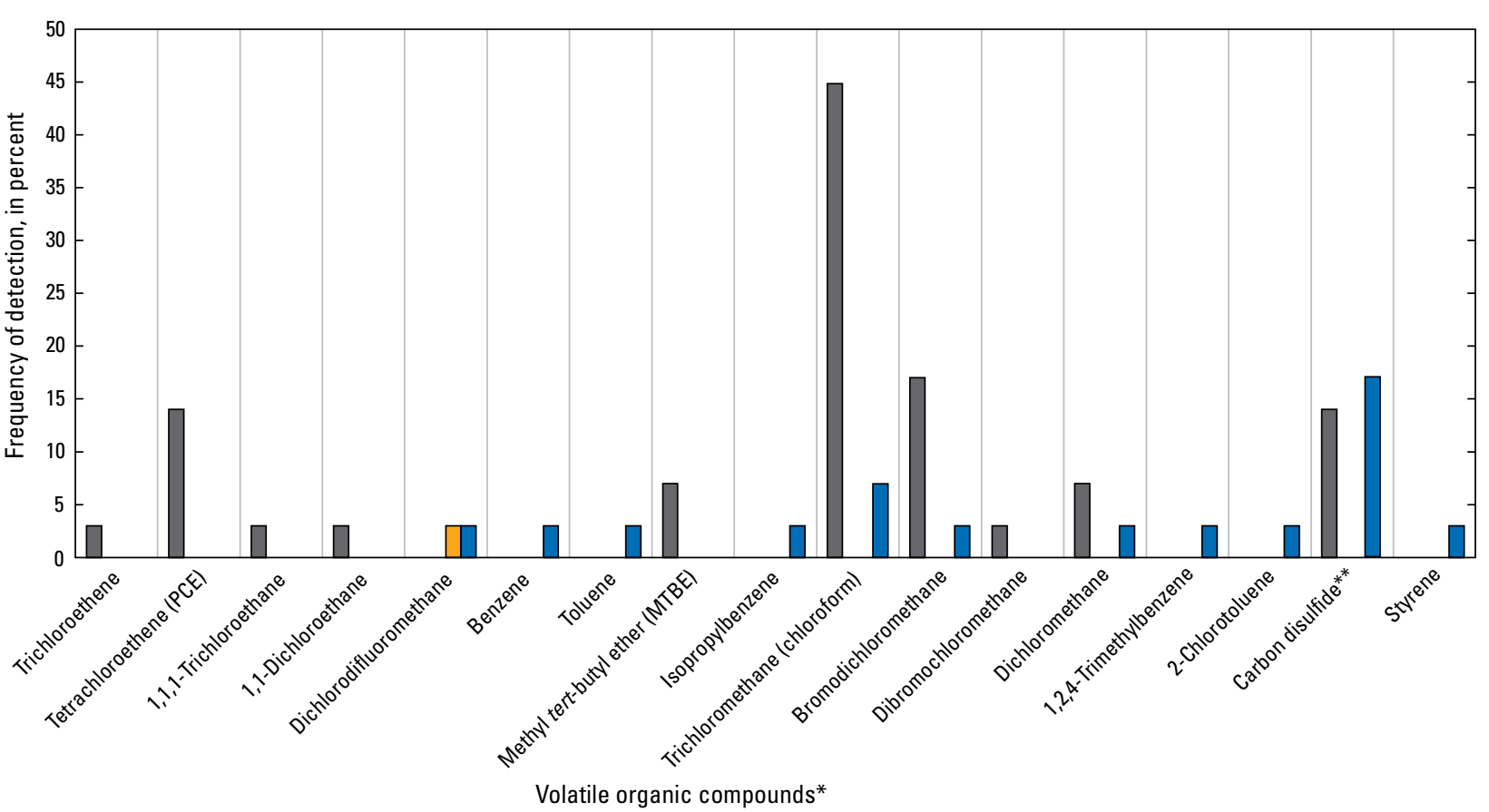

Figure 27. Frequency of detection of organic compounds for groundwater samples, Denver Basin aquifer system, Colorado, 2003-5. $A$, Pesticide compounds. $B$, Volatile organic compounds. 
Pesticides and VOCs were generally less frequently detected in samples from the bedrock aquifers than in those from the water-table wells, although several pesticides and VOCs were detected only in samples from the bedrock aquifers (VOCs were not analyzed in samples from the agricultural land-use wells) (fig. 27; table 9). Pesticides were detected in only two samples from the bedrock aquifers, both from the Dawson aquifer, with multiple pesticides detected in each (table 9); no VOCs were detected in these two samples. There were no pesticide detections in samples from the Arapahoe aquifer. Samples from the bedrock aquifers had more frequent VOC detections than pesticide detections, with one or more VOCs detected in 22 percent of samples; for most ( 85 percent) of these samples only one VOC was detected. The most frequently detected VOC for the bedrock aquifers was carbon disulfide, which was detected in 8 percent of samples (fig. 27; table 9). VOCs were detected more frequently in samples from the deeper Arapahoe aquifer (41 percent of samples) than in those from the shallower Dawson aquifer (3 percent of samples), with only a single VOC (dichlorodifluoromethane) detected in one sample from the Dawson aquifer.

Several factors might contribute to the frequent detection of carbon disulfide in samples from bedrock aquifers. Carbon disulfide has both natural and anthropogenic sources and is produced naturally by the microbial reduction of $\mathrm{SO}_{4}$ (Chin and Davis, 1993; Devai and DeLaune, 1995; Agency for Toxic Substances and Disease Registry, 1996). Fram and others (2012) noted that most carbon disulfide detections in groundwater samples collected for the California Groundwater Ambient Monitoring and Assessment Program occurred in anoxic samples, consistent with natural occurrence under $\mathrm{SO}_{4}$-reducing conditions. Similarly, all of the carbon disulfide detections in Arapahoe aquifer samples $(n=5)$ occurred in anoxic samples, and no other VOCs were detected in these samples. These carbon disulfide detections likely reflect natural sources of this compound. If carbon disulfide detections are not considered for the Arapahoe aquifer, the VOC detection frequency for Arapahoe aquifer samples drops from 41 to 24 percent. This detection frequency, however, still exceeds that for the Dawson aquifer.

Downward migrating recently recharged water, represented by samples from the water-table wells, is the likely source of contaminants to deeper groundwater in the bedrock aquifers. High groundwater pumping rates to supply water to the greater Denver metropolitan area have resulted in water-level declines in many bedrock-aquifer wells, which might increase the downward flow of shallow groundwater and associated contaminants to the deeper aquifers (Paschke, 2011). This alteration of the natural groundwater flow system has the potential to result in the transport of VOCs and other constituents present in shallow groundwater to the deeper bedrock aquifers. The Arapahoe aquifer is the most permeable and the most heavily pumped of the bedrock aquifers, accounting for 41 percent of bedrock-aquifer pumping (Paschke, 2011). Shortcomings in the construction or maintenance of wells, such as breaches in the well seal or well casing, might also allow for mixing with shallow groundwater (Eberts and others, 2013).

Two Arapahoe aquifer samples had multiple $(\mathrm{n}=3)$ VOC detections; both of these samples were oxic, which is consistent with the presence of downward migrating recently recharged water from the alluvial aquifer. These results indicate that in some locations the Arapahoe aquifer is vulnerable to contamination from shallow groundwater. Redox conditions might affect the transport and persistence of some VOCs between the shallow and deeper aquifers (Wiedemeier and others, 1999; Zogorski and others, 2006). For example, detection frequencies for chloroform and PCE - two of the most commonly detected VOCs in Denver Basin shallow groundwater (fig. 27) and two of the most commonly detected VOCs in groundwater across the Nation (Zogorski and others, 2006) - are more common under oxic conditions because of degradation in reducing conditions (McMahon and others, 2009). For the mostly anoxic Denver Basin bedrock aquifers, PCE was not detected, and chloroform was detected twice in oxic samples (fig. 27; table 9).

\section{Stable Isotopes of Hydrogen and Oxygen}

Stable isotope ratios of hydrogen (delta deuterium $[\delta \mathrm{D}])$ and oxygen (delta oxygen-18 $\left[\delta^{18} \mathrm{O}\right]$ ) are commonly used to study hydrologic processes and provide insight into groundwater origin, recharge sources, and processes such as mixing and evaporation (Clark and Fritz, 1997). Selected samples from the Denver Basin aquifer system were analyzed for stable isotopes (table 5). Median $\delta \mathrm{D}$ and $\delta^{18} \mathrm{O}$ values for samples from the water-table wells $(n=13)$ were -104 and -13.57 per mil, respectively. Median values for samples from the bedrock aquifers $(n=71)$ were mostly similar to those from the water-table wells, with the exception of those from the Laramie-Fox Hills aquifer, which were notably enriched (isotopically heavier), with median $\delta \mathrm{D}$ and $\delta^{18} \mathrm{O}$ values of -90.1 and -12.51 per mil, respectively (table 5). Median $\delta \mathrm{D}$ and $\delta^{18} \mathrm{O}$ values for the four bedrock aquifers became more enriched with depth, with median $\delta \mathrm{D}$ values for the Dawson, Denver, Arapahoe, and Laramie-Fox Hills aquifers of -107, $-104,-102$, and -90.1 per mil, respectively (table 5).

Comparison of stable isotope values for groundwater samples with the global meteoric water line (MWL) (Craig, 1961) and a local MWL for northeastern Colorado (Harvey, 2005 ) indicates that meteoric water was the primary groundwater recharge source for samples from both the watertable wells and the bedrock aquifers (fig. 28). Isotopic data for the water-table wells generally plotted slightly below and with a lesser slope than the global and local MWLs (fig. 28). The process of evaporation is consistent with these results (Clark and Fritz, 1997), indicating that groundwater sampled from the water-table wells was likely subject to varying amounts of evaporative concentration or has mixed with a component of recharge that has undergone evaporative concentration; Paschke and others (2013) estimated the amount of evaporative concentration to be as high as 36 percent. This hypothesis is consistent with the evaporative 
A

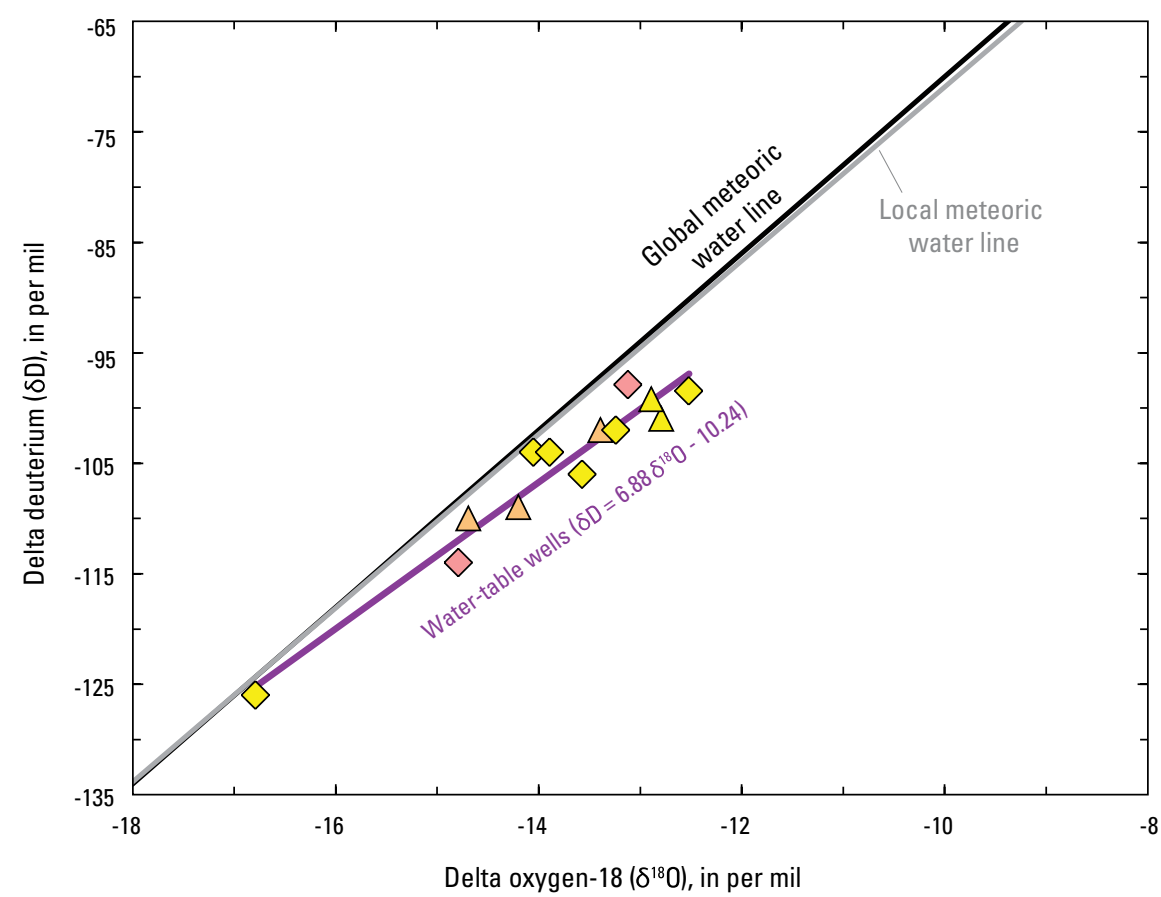

B

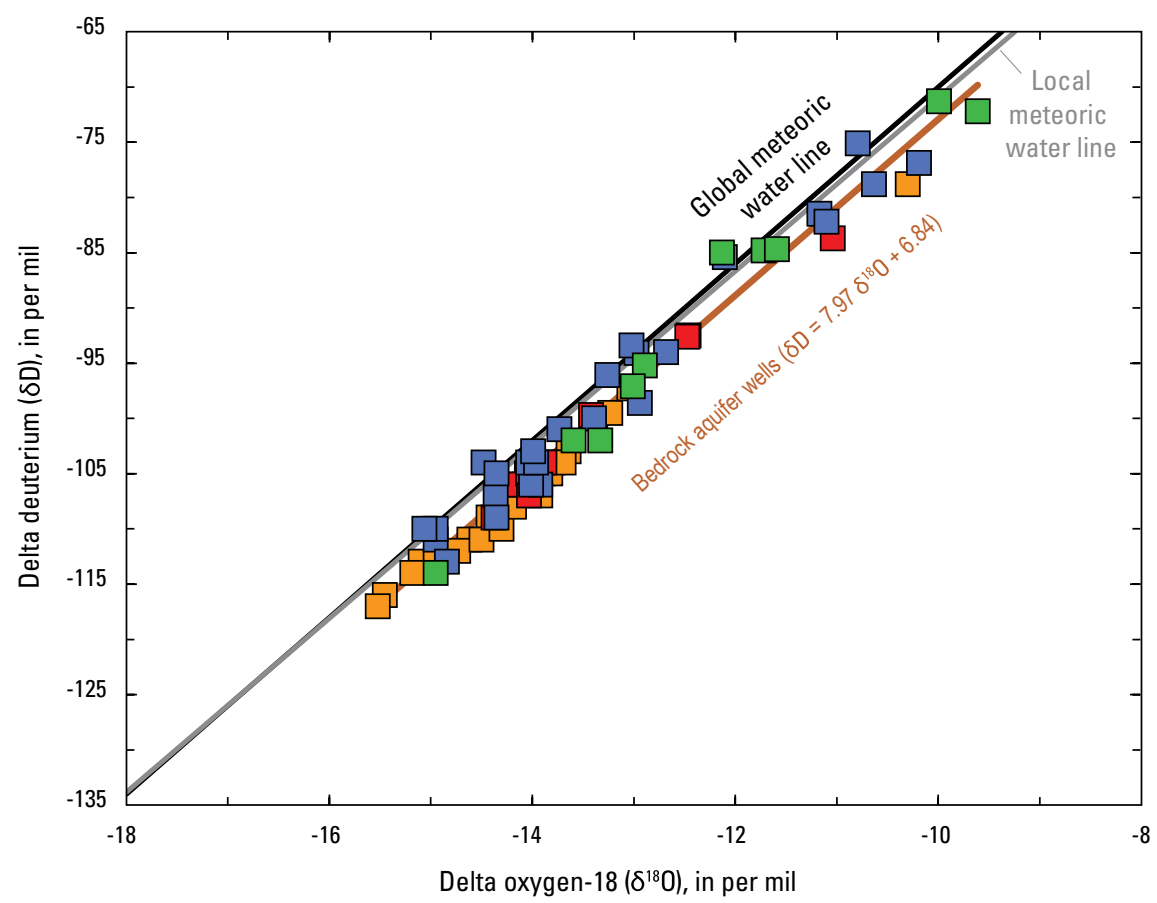
based on Harvey (2005) and Craig (1961), respectively.

Figure 28. Relation between deuterium and oxygen isotopes for groundwater samples, Denver Basin aquifer system, Colorado, 2003-5. $A$, Water-table well samples. $B$, Bedrock-aquifer samples. 
concentration of irrigation water in the shallow subsurface, the effect of which is also indicated by relatively high majorion and trace-element concentrations for samples from the water-table wells (table 5) and high evapotranspiration rates in the semiarid climate (Paschke, 2011). In addition to the concentration of solutes in water, evaporative concentration would also affect isotopic values, resulting in heavier $\delta^{18} \mathrm{O}$ values; a positive correlation between stable isotope values and (1) TDS concentrations, (2) conservative ion concentrations (such as $\mathrm{Cl}$ ), or (3) concentrations of trace elements (such as Se or U) might indicate if evaporative concentration has affected these solutes. Values of $\delta^{18} \mathrm{O}$ for water-table well samples were correlated with $\mathrm{Cl}$ concentration (Kendall's tau $=0.44$ ); other constituents, such as TDS and selected trace elements, were not correlated with $\delta^{18} \mathrm{O}$ values. These mixed results might partially reflect that a relatively small number of water-table well samples $(\mathrm{n}=$ 13) were analyzed for stable isotopes, making it difficult to evaluate the effects of evaporation on shallow groundwater. Effects of evaporation on stable isotope values for surface water and shallow groundwater in the watershed of Toll Gate Creek, near the center of the Denver Basin study area, have been documented (Paschke and others, 2013). As discussed by Paschke and others (2013), however, it is unlikely that evaporative concentration is the only process accounting for relatively high major- and trace-ion concentrations in shallow groundwater of the Denver Basin; factors such as water-rock interaction with soils and sediments, or relatively long residence times, likely also contribute to the observed geochemistry.
Isotopic data for the bedrock aquifers plot along and have a slope similar to the global and local MWLs (fig. 28), which indicate that meteoric recharge to the bedrock aquifers was not affected by evaporation and that the data likely reflect the isotopic composition of recharge to the aquifers. Most bedrock-aquifer samples had a range of stable isotope values similar to that of the water-table well samples, but a small group of samples $(n=13)$, mostly from the Arapahoe and Laramie-Fox Hills aquifers, had enriched (isotopically heavier) values that plotted in a distinct cluster from the main grouping of data, with $\delta \mathrm{D}$ (fig. 28) ranging from about -86 to -70 per mil. Harvey (2005) described a large range in $\delta \mathrm{D}$ values for modern precipitation sampled from 1994 through 1998 , ranging from -10 to -225 per mil, which is typical of midcontinental areas globally (Gat and Gonfiantini, 1981) and encompasses the range of values for groundwater samples analyzed for the current study. Nonetheless, the observed differences in isotopic values for some of the bedrockaquifer samples might be associated with recharge during different climatic conditions or with recharge at relatively low altitudes, such as has been attributed to a group of samples in the Rio Grande Basin (Plummer and others, 2004). Results for groundwater age tracers, discussed in the subsequent section, indicate that the deeper bedrock aquifers generally are characterized by old groundwater, typically many thousands of years old, which might have recharged during different climatic conditions. Stable isotope values for the bedrock aquifers, however, were not significantly correlated with agetracer results (detailed in the next section) such as adjusted ${ }^{14} \mathrm{C}$ ages (fig. 29) or ${ }^{3} \mathrm{H}$ values, indicating that the enriched values

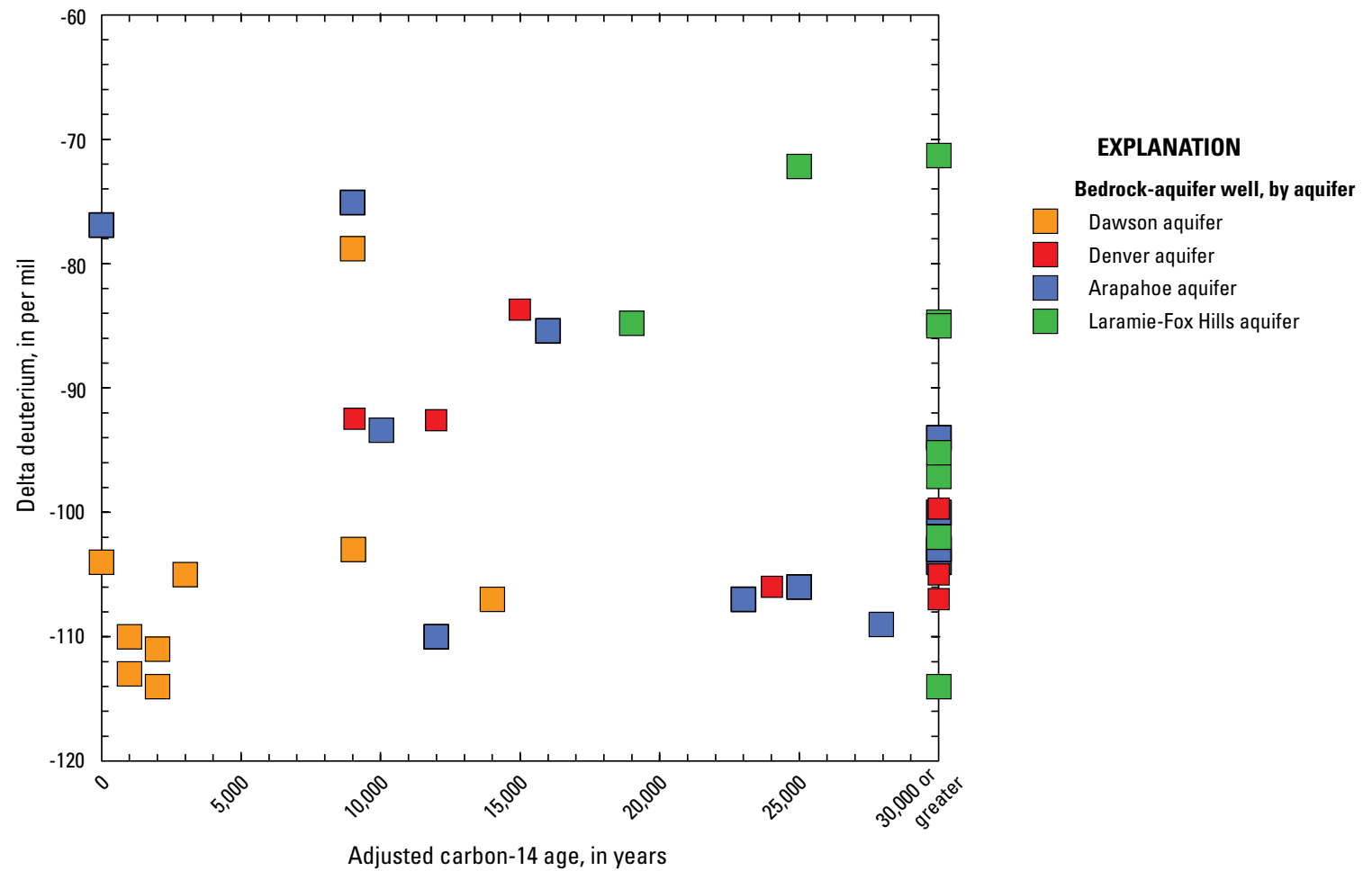

Figure 29. Relation between deuterium isotopes and adjusted carbon-14 ages for bedrock-aquifer samples, Denver Basin aquifer system, Colorado, 2003-5. 
are not representative of recharge during different climatic conditions. Most of the samples with enriched stable isotope values were from areas in the southern part of the study area along the Palmer Divide (fig. 30), which suggests that factors such as recharge altitude and spatial variability along regional flow paths contribute to the range of stable isotope values for the bedrock aquifers.

\section{Groundwater Age Tracers and Age Distributions}

Estimating the age of groundwater is useful for understanding selected aspects of hydrogeology, such as recharge rates, rates of geochemical and microbiological processes, aquifer susceptibility and vulnerability to contamination, and water-resource management (Plummer, 2005). Age tracers were analyzed in selected samples from water-table and bedrock-aquifer wells (table 2). Groundwater age (time since recharge) and the extent of mixing of young and old groundwater were estimated by using concentrations, ratios, and interpretation of $\mathrm{CFCs},{ }^{3} \mathrm{H}$, and ${ }^{14} \mathrm{C}$ data. Dissolved gas and ${ }^{13} \mathrm{C}$ isotope data supported interpretation of these tracers. $\mathrm{CFC}$ and ${ }^{3} \mathrm{H}$ data were collected to investigate the young fraction of recharge, and ${ }^{14} \mathrm{C}$ data were collected to investigate the old fraction of recharge. Groundwater ages for samples from the water-table wells were estimated on the basis of CFC concentrations; no ${ }^{3} \mathrm{H}$ or ${ }^{14} \mathrm{C}$ data were collected from these wells. Bedrock-aquifer wells were sampled for a mix of tracers (table 2). Age interpretations were based on integration of available data. Evaluation of individual tracers is discussed below, followed by presentation of interpreted groundwater ages.

\section{Chlorofluorocarbons}

CFCs were analyzed in selected samples from water-table and bedrock-aquifer wells (table 10). CFC concentrations generally were relatively high in samples from the watertable wells and decreased with well depth; relatively high concentrations, however, were measured in two samples from the bedrock-aquifer wells (fig. 31; table 10). Results for water-table well samples mostly were indicative of young water, with piston-flow ages ranging from 14 to 33 years since recharge occurred. Low CFC concentrations were measured in many of the samples from the bedrock aquifers, which yielded piston-flow ages indicating that recharge occurred between 1945 and 1955, near the practical limit of the CFC age-dating method. For most of these samples, however, little or no ${ }^{3} \mathrm{H}$ or ${ }^{14} \mathrm{C}$ was detected. These results indicate that the low concentrations of CFCs that were measured might have resulted from contamination during sampling. The uncertainty associated with CFC concentration data limited their utility for evaluating the age of groundwater in the bedrock aquifers. Low-level CFC contamination was suspected and is noted for some of the bedrock-aquifer samples, along with suspect associated age interpretations (table 10). 


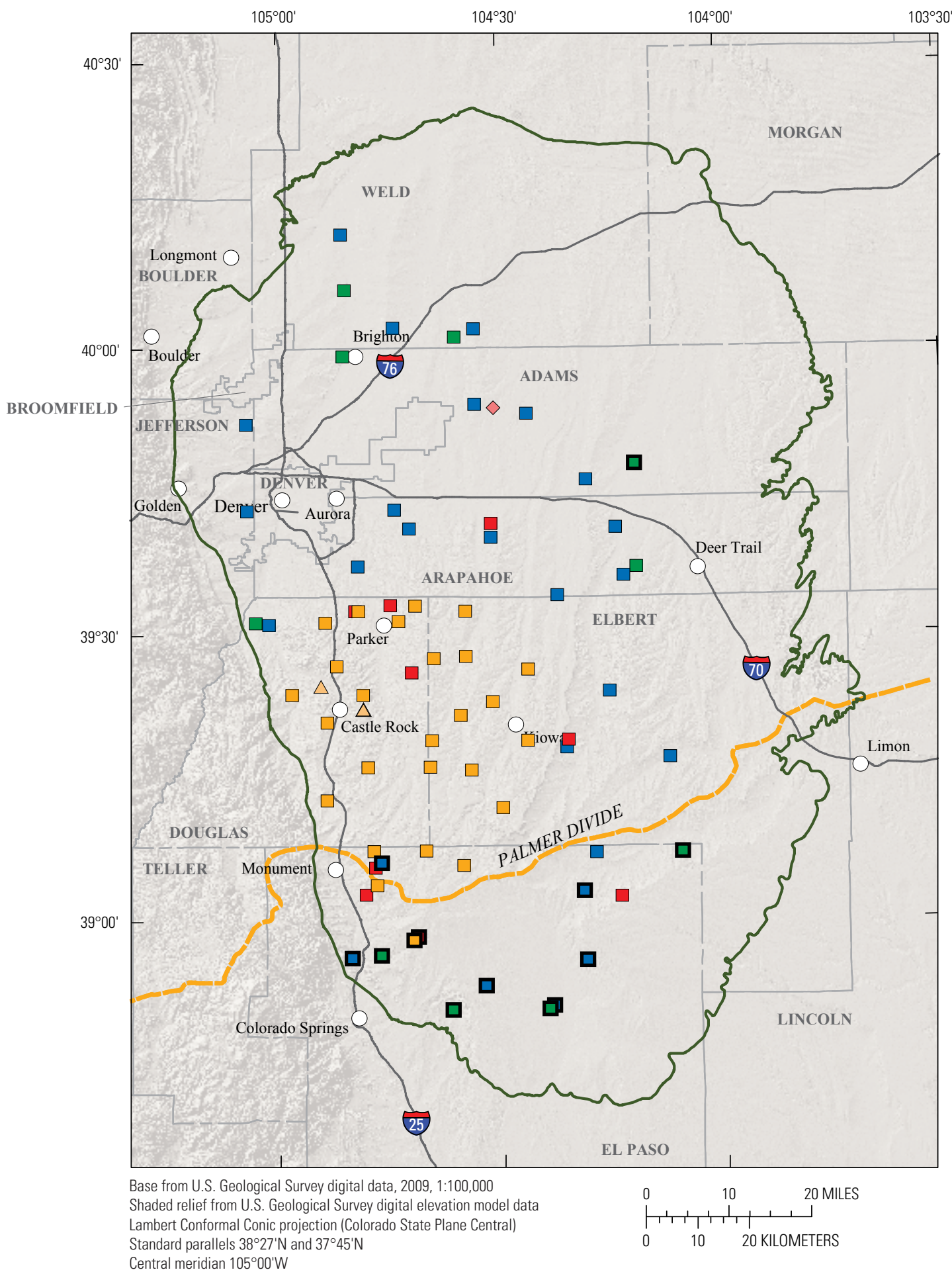

EXPLANATION

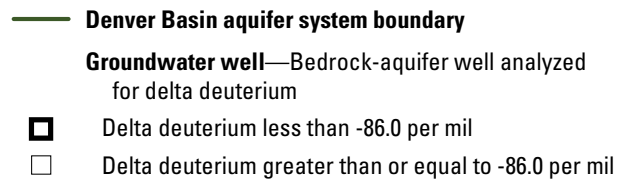

Denver Basin bedrock-aquifer well, by aquifer
$\square \quad$ Dawson aquifer
$\square \quad$ Denver aquifer
$\square \quad$ Arapahoe aquifer
$\square \quad$ Laramie-Fox Hills aquifer

Figure 30. Hydrogeologic setting and locations of bedrock-aquifer wells distinguished by enriched delta-deuterium values, Denver Basin aquifer system, Colorado, 2003-5. 
Table 10. Summary of chlorofluorocarbon and tritium age-tracer and associated data for groundwater samples, Denver Basin aquifer system, Colorado, 2003-5.

[Values shown with a strikethrough were determined to be unsuitable for groundwater age intepretation; see comment. USGS, U.S. Geological Survey; ft, feet; $\mathrm{CH}_{4}$, methane; $\mathrm{mg} / \mathrm{L}$, milligrams per liter; $\mathrm{CO}_{2}$, carbon dioxide; $\mathrm{N}_{2}$, nitrogen gas; $\mathrm{O}_{2}$, oxygen gas; $\mathrm{Ar}$, argon; cc STP/L, cubic centimeters at standard pressure and temperature per liter; temp, temperature; ${ }^{\circ} \mathrm{C}$, degrees Celsius; $\mathrm{CFC}$, chlorofluorocarbon; pptv, parts per trillion by volume; M, present but not quantified; \%, percent; ${ }^{3} \mathrm{H}$, tritium; TU, tritium units; mg/L, milligrams per liter; C, contaminated; >, greater than; --, not measured; na, not applicable]

\begin{tabular}{|c|c|c|c|c|c|c|c|c|c|c|c|}
\hline \multicolumn{4}{|c|}{ Site information } & \multicolumn{8}{|c|}{ Dissolved gases and other associated data } \\
\hline Aquifer & $\begin{array}{c}\text { USGS site } \\
\text { identification } \\
\text { number }\end{array}$ & $\begin{array}{l}\text { Local well } \\
\text { name } \\
\text { (final wells) }\end{array}$ & $\begin{array}{c}\text { Sample } \\
\text { date }\end{array}$ & $\underset{(\mathrm{mg} / \mathrm{L})}{\mathrm{CH}_{4}}$ & $\begin{array}{c}\mathrm{CO}_{2} \\
(\mathrm{mg} / \mathrm{L})\end{array}$ & $\underset{(\mathrm{mg} / \mathrm{L})}{\mathrm{N}_{2}}$ & $\begin{array}{c}\mathbf{O}_{2} \\
(\mathrm{mg} / \mathrm{L})\end{array}$ & $\underset{(\mathrm{mg} / \mathrm{L})}{\mathrm{Ar}}$ & $\begin{array}{l}\text { Excess air } \\
\text { (cc STP/L) }\end{array}$ & $\begin{array}{c}\text { Calculated } \\
\text { or assigned } \\
\text { recharge temp } \\
\left({ }^{\circ} \mathrm{C}\right)\end{array}$ & $\begin{array}{c}\text { Recharge } \\
\text { altitude } \\
\text { (ft) }\end{array}$ \\
\hline \multirow{15}{*}{$\begin{array}{l}\text { Water-table } \\
\text { wells }\end{array}$} & 394310104393401 & AGLUS 1 & $7 / 29 / 2003$ & 0.00 & 41.72 & 19.04 & 0.04 & 0.56 & -- & 11.0 & 5,619 \\
\hline & 395909104350401 & AGLUS 6 & $7 / 28 / 2003$ & 0.00 & 13.37 & 17.89 & 4.06 & 0.61 & 3.3 & 10.7 & 5,068 \\
\hline & 395541104385701 & AGLUS 7 & $7 / 28 / 2003$ & -- & -- & -- & -- & -- & -- & 11.0 & 5,245 \\
\hline & 394539104305901 & AGLUS 12 & $8 / 4 / 2003$ & -- & -- & -- & -- & -- & -- & 11.0 & 5,550 \\
\hline & 394947104335201 & AGLUS 14 & $7 / 31 / 2003$ & -- & -- & -- & -- & -- & -- & 11.0 & 5,450 \\
\hline & 395352104302801 & AGLUS 18 & $7 / 31 / 2003$ & -- & -- & -- & -- & -- & -- & 11.0 & 5,455 \\
\hline & 394919104291001 & AGLUS 20 & $8 / 4 / 2003$ & -- & -- & -- & -- & -- & -- & 11.0 & 5,395 \\
\hline & 394351104302901 & AGLUS REF2 & $7 / 30 / 2003$ & -- & -- & -- & -- & -- & -- & 11.0 & 5,900 \\
\hline & 393458104544101 & URLUS 6 & $11 / 20 / 2003$ & -- & -- & -- & -- & -- & -- & 16.5 & 5,603 \\
\hline & 393408104544001 & URLUS 7 & $11 / 20 / 2003$ & 0.00 & 107.52 & 15.45 & 0.05 & 0.52 & 2.8 & 17.1 & 5,733 \\
\hline & 393846104465501 & URLUS 18 & $12 / 8 / 2003$ & 0.00 & 30.79 & 15.71 & 0.06 & 0.53 & 2.8 & 16.5 & 5,725 \\
\hline & 393655104463001 & URLUS 21 & $12 / 1 / 2003$ & -- & -- & -- & -- & -- & -- & 16.5 & 5,789 \\
\hline & 393654104472001 & URLUS 22 & $12 / 1 / 2003$ & -- & -- & -- & -- & -- & -- & 16.5 & 5,764 \\
\hline & 393057104441101 & URLUS 24 & $11 / 25 / 2003$ & -- & -- & -- & -- & -- & -- & 16.5 & 5,953 \\
\hline & 393700104454101 & URLUS 26 & $12 / 2 / 2003$ & -- & -- & -- & -- & -- & -- & 16.5 & 5,914 \\
\hline \multirow{12}{*}{ Dawson } & 393226104490101 & DAWMAS 07 & $12 / 10 / 2004$ & 0.00 & 29.42 & 18.68 & 3.84 & 0.63 & 3.2 & 8.6 & 5,890 \\
\hline & 393125104433701 & DAWMAS 08 & $12 / 3 / 2004$ & 0.03 & 10.40 & 19.70 & 0.10 & 0.60 & 5.1 & 9.8 & 6,130 \\
\hline & 392339104482601 & DAWMAS 09 & $12 / 7 / 2004$ & 0.01 & 3.10 & 22.09 & 0.08 & 0.74 & 5.4 & 2.2 & 6,480 \\
\hline & 391605104475001 & DAWMAS 10 & $1 / 20 / 2005$ & 0.00 & 21.35 & 16.00 & 5.18 & 0.57 & 1.9 & 9.7 & 6,720 \\
\hline & 390716104470801 & DAWMAS 11 & $12 / 2 / 2004$ & 0.00 & 17.39 & 17.84 & 3.19 & 0.62 & 2.9 & 6.5 & 7,360 \\
\hline & 390342104464401 & DAWMAS 12 & $12 / 9 / 2004$ & 0.00 & 31.18 & 18.85 & 2.59 & 0.63 & 4.1 & 7.2 & 7,420 \\
\hline & 385758104414801 & DAWMAS 13 & $12 / 13 / 2005$ & 0.00 & 21.34 & 18.67 & 0.00 & 0.63 & 4.0 & 7.5 & 7,100 \\
\hline & 390717104400401 & DAWMAS 14 & $11 / 30 / 2004$ & 0.00 & 3.25 & 21.74 & 1.37 & 0.71 & 5.9 & 3.8 & 7,340 \\
\hline & 391606104392701 & DAWMAS 15 & $12 / 1 / 2004$ & 0.00 & 18.19 & 17.36 & 4.15 & 0.61 & 2.3 & 6.8 & 6,870 \\
\hline & 392727104385201 & DAWMAS 17 & $12 / 28 / 2004$ & 0.00 & 22.23 & 15.61 & 5.32 & 0.56 & 1.5 & 10.5 & 6,510 \\
\hline & 391148104294101 & DAWMAS 27 & $12 / 8 / 2004$ & 0.00 & 19.59 & 15.58 & 2.16 & 0.55 & 1.8 & 11.0 & 6,960 \\
\hline & 391848104261401 & DAWMAS 28 & $12 / 14 / 2004$ & 0.00 & 28.54 & 16.51 & 3.26 & 0.57 & 2.7 & 11.2 & 6,740 \\
\hline \multirow{4}{*}{ Denver } & 385816104411201 & DENMAS 04 & $10 / 1 / 2005$ & 0.00 & 7.86 & 25.14 & 0.00 & 0.76 & 9.5 & 4.5 & 7,140 \\
\hline & 391851104204501 & DENMAS 05 & $12 / 29 / 2005$ & 0.18 & 1.56 & 21.68 & 0.00 & 0.69 & 6.6 & 7.7 & 6,080 \\
\hline & 393227104493001 & DENMAS 08 & $10 / 13 / 2005$ & 0.01 & 2.41 & 23.75 & 0.01 & 0.73 & 8.5 & 7.9 & 5,850 \\
\hline & 390243104481401 & DENMAS 10 & $12 / 1 / 2005$ & 0.05 & 4.13 & 19.67 & 0.00 & 0.65 & 4.5 & 6.6 & 7,080 \\
\hline \multirow{5}{*}{ Arapahoe } & 395408104335301 & ARAPMAS 17 & $7 / 15 / 2005$ & 0.03 & 0.88 & 20.33 & 0.04 & 0.66 & 5.1 & 9.1 & 5,300 \\
\hline & 394618104184201 & ARAPMAS 20 & $7 / 19 / 2005$ & 0.11 & 0.77 & 18.02 & 0.10 & 0.61 & 3.6 & 11.2 & 5,300 \\
\hline & 391834104205601 & ARAPMAS 22 & $7 / 1 / 2005$ & 0.02 & 0.70 & 20.10 & 0.02 & 0.63 & 6.6 & 12.0 & 6,140 \\
\hline & 385059104231201 & ARAPMAS 24 & $10 / 1 / 2005$ & 0.00 & 12.32 & 20.80 & 5.98 & 0.63 & 7.3 & 13.4 & 6,050 \\
\hline & 390341104135001 & ARAPMAS 26 & $7 / 20 / 2005$ & 0.26 & 0.21 & 17.36 & 0.20 & 0.57 & 4.1 & 12.9 & 6,420 \\
\hline \multirow{3}{*}{$\begin{array}{l}\text { Laramie-Fox } \\
\text { Hills }\end{array}$} & 394748104112301 & LFHMAS 04 & $11 / 29 / 2005$ & 1.89 & 0.43 & 20.02 & 0.00 & 0.62 & 6.4 & 14.8 & 5,055 \\
\hline & 393659104111801 & LFHMAS 05 & $11 / 17 / 2005$ & 0.28 & 0.21 & 18.54 & 0.00 & 0.59 & 5.1 & 14.3 & 5,390 \\
\hline & 400607104503901 & LFHMAS 10 & $12 / 9 / 2005$ & 10.29 & 1.49 & 28.33 & 0.00 & 0.80 & 13.2 & 9.3 & 5,910 \\
\hline
\end{tabular}


Table 10. Summary of chlorofluorocarbon and tritium age-tracer and associated data for groundwater samples, Denver Basin aquifer system, Colorado, 2003-5.-Continued

[Values shown with a strikethrough were determined to be unsuitable for groundwater age intepretation; see comment. USGS, U.S. Geological Survey; ft, feet; $\mathrm{CH}_{4}$, methane; $\mathrm{mg} / \mathrm{L}$, milligrams per liter; $\mathrm{CO}_{2}$, carbon dioxide; $\mathrm{N}_{2}$, nitrogen gas; $\mathrm{O}_{2}$, oxygen gas; Ar, argon; cc STP/L, cubic centimeters at standard pressure and temperature per liter; temp, temperature; ${ }^{\circ} \mathrm{C}$, degrees Celsius; $\mathrm{CFC}$, chlorofluorocarbon; pptv, parts per trillion by volume; M, present but not quantified; \%, percent; ${ }^{3} \mathrm{H}$, tritium; TU, tritium units; $\mathrm{mg} / \mathrm{L}$, milligrams per liter; $\mathrm{C}$, contaminated; >, greater than; --, not measured; na, not applicable]

\begin{tabular}{|c|c|c|c|c|c|c|c|c|c|c|c|c|}
\hline \multicolumn{4}{|c|}{ Site information } & \multicolumn{6}{|c|}{ CFCs and piston-flow model results } & \multirow[b]{2}{*}{$\begin{array}{c}{ }^{3} \mathrm{H} \\
\text { (TU) }\end{array}$} & \multirow[b]{2}{*}{$\begin{array}{c}\text { Dis- } \\
\text { solved } \\
\text { oxygen } \\
(\mathrm{mg} / \mathrm{L})\end{array}$} & \multirow[b]{2}{*}{ Comment } \\
\hline Aquifer & $\begin{array}{c}\text { USGS site } \\
\text { identification } \\
\text { number }\end{array}$ & $\begin{array}{l}\text { Local well } \\
\text { name } \\
\text { (final wells) }\end{array}$ & $\begin{array}{c}\text { Sample } \\
\text { date }\end{array}$ & $\begin{array}{l}\text { CFC-11, } \\
\text { atmospheric } \\
\text { mixing } \\
\text { ratio } \\
\text { (pptv) }\end{array}$ & $\begin{array}{c}\text { CFC-12, } \\
\text { atmospheric } \\
\text { mixing } \\
\text { ratio } \\
\text { (pptv) }\end{array}$ & $\begin{array}{c}\text { CFC-113, } \\
\text { atmospheric } \\
\text { mixing ratio } \\
\text { (pptv) }\end{array}$ & $\begin{array}{l}\text { Basis for } \\
\text { piston- } \\
\text { flow } \\
\text { model }\end{array}$ & $\begin{array}{l}\text { Piston- } \\
\text { flow } \\
\text { model } \\
\text { apparent } \\
\text { year of } \\
\text { recharge }\end{array}$ & $\begin{array}{l}\text { Piston- } \\
\text { flow } \\
\text { model } \\
\text { appar- } \\
\text { ent age } \\
\text { (years) }\end{array}$ & & & \\
\hline \multirow{15}{*}{$\begin{array}{l}\text { Water- } \\
\text { table } \\
\text { wells }\end{array}$} & 394310104393401 & AGLUS 1 & $7 / 29 / 2003$ & 38.5 & 146.9 & 19.6 & CFC-12 & 1971 & 33 & -- & 2.4 & \\
\hline & 395909104350401 & AGLUS 6 & $7 / 28 / 2003$ & 111.7 & 251.5 & 26.2 & CFC-12 & 1975 & 28 & -- & 6.6 & \\
\hline & 395541104385701 & AGLUS 7 & $7 / 28 / 2003$ & 137.8 & 364.4 & 49.9 & CFC-12 & 1983 & 21 & -- & 4.3 & \\
\hline & 394539104305901 & AGLUS 12 & $8 / 4 / 2003$ & 95.8 & $\mathrm{C}(794.3)$ & 44.8 & CFC-113 & 1985 & 19 & -- & 2.8 & \\
\hline & 394947104335201 & AGLUS 14 & $7 / 31 / 2003$ & 215.9 & 422.3 & 63.1 & CFC-12 & 1988 & 16 & -- & 8.6 & \\
\hline & 395352104302801 & AGLUS 18 & $7 / 31 / 2003$ & 116.1 & 302.1 & 19.9 & CFC-12 & 1980 & 24 & -- & 9.2 & \\
\hline & 394919104291001 & AGLUS 20 & $8 / 4 / 2003$ & 203.9 & 478.1 & 78.1 & CFC-12 & 1989 & 15 & -- & 11.5 & \\
\hline & 394351104302901 & AGLUS REF2 & $7 / 30 / 2003$ & 37.4 & 261.7 & 19.0 & CFC-12 & 1977 & 27 & -- & 0.5 & \\
\hline & 393458104544101 & URLUS 6 & $11 / 20 / 2003$ & 247.4 & $\mathrm{C}(817.4)$ & 76.1 & CFC-113 & 1990 & 14 & -- & 0.2 & \\
\hline & 393408104544001 & URLUS 7 & $11 / 20 / 2003$ & $\mathrm{C}(764.3)$ & $\mathrm{C}(4,320.2)$ & 22.3 & CFC-113 & 1980 & 24 & -- & 0.8 & \\
\hline & 393846104465501 & URLUS 18 & $12 / 8 / 2003$ & $\mathrm{C}(424.1)$ & $\mathrm{C}(648.2)$ & 67.1 & CFC-113 & 1989 & 15 & -- & 0.8 & \\
\hline & 393655104463001 & URLUS 21 & $12 / 1 / 2003$ & $\mathrm{C}(1,476.7)$ & $\mathrm{C}(4,371.4)$ & 20.4 & CFC-113 & 1979 & 25 & -- & 0.3 & \\
\hline & 393654104472001 & URLUS 22 & $12 / 1 / 2003$ & $\mathrm{C}(412.6)$ & $\mathrm{C}(668.7)$ & 68.4 & CFC-113 & 1989 & 15 & -- & 0.5 & \\
\hline & 393057104441101 & URLUS 24 & $11 / 25 / 2003$ & 9.0 & 177.4 & 2.7 & $\begin{array}{l}\text { CFC-12 } \\
\text { (CFCs } \\
\text { possibly } \\
\text { degraded) }\end{array}$ & 1973 & 31 & -- & 0.3 & $\begin{array}{l}\text { Unsuitable for age } \\
\text { determination due to } \\
\text { possible degradation; } \\
\text { age likely younger than } \\
\text { piston-flow model age. }\end{array}$ \\
\hline & 393700104454101 & URLUS 26 & $12 / 2 / 2003$ & C (399.4) & $\mathrm{C}(668.1)$ & C (94.3) & na & Modern & Modern & -- & 7.5 & $\begin{array}{l}\text { CFC age determination } \\
\text { not possible due to } \\
\text { contamination; likely } \\
\text { modern (young) in age. }\end{array}$ \\
\hline
\end{tabular}


Table 10. Summary of chlorofluorocarbon and tritium age-tracer and associated data for groundwater samples, Denver Basin aquifer system, Colorado, 2003-5.-Continued

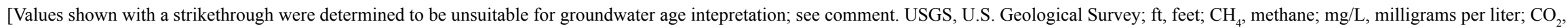
carbon dioxide; $\mathrm{N}_{2}$, nitrogen gas; $\mathrm{O}_{2}$, oxygen gas; Ar, argon; cc STP/L, cubic centimeters at standard pressure and temperature per liter; temp, temperature; ${ }^{\circ} \mathrm{C}$, degrees Celsius; $\mathrm{CFC}$, chlorofluorocarbon; pptv, parts per trillion by volume; M, present but not quantified; \%, percent; ${ }^{3} \mathrm{H}$, tritium; TU, tritium units; $\mathrm{mg} / \mathrm{L}$, milligrams per liter; $\mathrm{C}$, contaminated; >, greater than; --, not measured; na, not applicable]

\begin{tabular}{|c|c|c|c|c|c|c|c|c|c|c|c|c|}
\hline \multicolumn{4}{|c|}{ Site information } & \multicolumn{6}{|c|}{ CFCs and piston-flow model results } & \multirow[b]{2}{*}{$\begin{array}{c}{ }^{3} \mathrm{H} \\
\text { (TU) }\end{array}$} & \multirow[b]{2}{*}{$\begin{array}{c}\text { Dis- } \\
\text { solved } \\
\text { oxygen } \\
\text { (mg/L) }\end{array}$} & \multirow[b]{2}{*}{ Comment } \\
\hline Aquifer & $\begin{array}{c}\text { USGS site } \\
\text { identification } \\
\text { number }\end{array}$ & $\begin{array}{l}\text { Local well } \\
\text { name } \\
\text { (final wells) }\end{array}$ & $\begin{array}{c}\text { Sample } \\
\text { date }\end{array}$ & $\begin{array}{c}\text { CFC-11, } \\
\text { atmospheric } \\
\text { mixing } \\
\text { ratio } \\
\text { (pptv) }\end{array}$ & $\begin{array}{c}\text { CFC-12, } \\
\text { atmospheric } \\
\text { mixing } \\
\text { ratio } \\
\text { (pptv) }\end{array}$ & $\begin{array}{c}\text { CFC-113, } \\
\text { atmospheric } \\
\text { mixing ratio } \\
\text { (pptv) }\end{array}$ & $\begin{array}{l}\text { Basis for } \\
\text { piston- } \\
\text { flow } \\
\text { model }\end{array}$ & $\begin{array}{l}\text { Piston- } \\
\text { flow } \\
\text { model } \\
\text { apparent } \\
\text { year of } \\
\text { recharge }\end{array}$ & $\begin{array}{l}\text { Piston- } \\
\text { flow } \\
\text { model } \\
\text { appar- } \\
\text { ent age } \\
\text { (years) }\end{array}$ & & & \\
\hline \multirow{12}{*}{ Dawson } & 393226104490101 & DAWMAS 07 & $12 / 10 / 2004$ & 191.9 & 528.8 & 57.8 & CFC-113 & 1988 & 17 & 13.4 & 4.5 & \\
\hline & 393125104433701 & DAWMAS 08 & $12 / 3 / 2004$ & C (494.3) & 19.9 & 0.9 & CFC-12 & 1956 & 49 & 0.4 & 1.7 & \\
\hline & 392339104482601 & DAWMAS 09 & $12 / 7 / 2004$ & 7.4 & $\mathrm{C}(953.8)$ & 0.9 & CFC-113 & 1957 & 48 & $<0.2$ & 3.7 & \\
\hline & 391605104475001 & DAWMAS 10 & $1 / 20 / 2005$ & 55.4 & 169.2 & 16.6 & CFC-12 & 1972 & 33 & 3.8 & 7.9 & \\
\hline & 390716104470801 & DAWMAS 11 & $12 / 2 / 2004$ & 3.9 & 10.8 & 0.9 & CFC-12 & 1952 & 53 & $<0.2$ & 3.9 & $\begin{array}{l}\text { CFC age interpretation } \\
\text { suspect due to possible } \\
\text { low-level contamination. }\end{array}$ \\
\hline & 390342104464401 & DAWMAS 12 & $12 / 9 / 2004$ & 4.6 & 18.0 & 1.8 & CFC-12 & 1955 & 50 & $<0.2$ & 5.6 & $\begin{array}{l}\text { Age interpretation suspect } \\
\text { due to possible low-level } \\
\text { CFC contamination. }\end{array}$ \\
\hline & 385758104414801 & DAWMAS 13 & $12 / 13 / 2005$ & 4.5 & 31.8 & 1.3 & CFC-12 & 1959 & 47 & 1.0 & 0.1 & \\
\hline & 390717104400401 & DAWMAS 14 & $11 / 30 / 2004$ & 3.2 & 5.7 & 0.0 & CFC-12 & 1949 & 56 & $<0.2$ & 2.1 & $\begin{array}{l}\text { Age interpretation suspect } \\
\text { due to possible low-level } \\
\text { CFC contamination. }\end{array}$ \\
\hline & 391606104392701 & DAWMAS 15 & $12 / 1 / 2004$ & 3.7 & 21.7 & 2.3 & CFC-12 & 1957 & 48 & $<0.2$ & 4.8 & $\begin{array}{l}\text { Age interpretation suspect } \\
\text { due to possible low-level } \\
\text { CFC contamination. }\end{array}$ \\
\hline & 392727104385201 & DAWMAS 17 & $12 / 28 / 2004$ & 19.7 & 98.6 & 16.6 & CFC-12 & 1968 & 38 & 7.5 & 8.8 & \\
\hline & 391148104294101 & DAWMAS 27 & $12 / 8 / 2004$ & 26.2 & 72.2 & 5.3 & CFC-12 & 1965 & 40 & 1.7 & 9.4 & \\
\hline & 391848104261401 & DAWMAS 28 & $12 / 14 / 2004$ & 53.4 & 151.3 & 19.4 & CFC-12 & 1971 & 34 & 0.6 & 4.8 & \\
\hline \multirow{4}{*}{ Denver } & 385816104411201 & DENMAS 04 & $10 / 1 / 2005$ & 3.8 & 4.0 & 2.4 & CFC-12 & 1948 & 58 & 0.5 & 0.1 & $\begin{array}{l}\text { Age interpretation suspect } \\
\text { due to possible low-level } \\
\text { CFC contamination and } \\
\text { (or) degradation. }\end{array}$ \\
\hline & 391851104204501 & DENMAS 05 & $12 / 29 / 2005$ & 2.7 & 2.1 & 0.0 & CFC-12 & 1946 & 61 & $<0.1$ & 0.0 & $\begin{array}{l}\text { Age interpretation suspect } \\
\text { due to possible low-level } \\
\text { CFC contamination and } \\
\text { (or) degradation. }\end{array}$ \\
\hline & 393227104493001 & DENMAS 08 & $10 / 13 / 2005$ & 8.4 & 131.5 & 6.4 & CFC-12 & 1970 & 36 & 2.2 & 0.2 & \\
\hline & 390243104481401 & DENMAS 10 & $12 / 1 / 2005$ & 4.4 & 5.6 & 3.5 & CFC-12 & 1949 & 57 & $<0.2$ & 0.6 & $\begin{array}{l}\text { Age interpretation suspect } \\
\text { due to possible low-level } \\
\text { CFC contamination and } \\
\text { (or) degradation. }\end{array}$ \\
\hline
\end{tabular}


Table 10. Summary of chlorofluorocarbon and tritium age-tracer and associated data for groundwater samples, Denver Basin aquifer system, Colorado, 2003-5.-Continued

[Values shown with a strikethrough were determined to be unsuitable for groundwater age intepretation; see comment. USGS, U.S. Geological Survey; ft, feet; $\mathrm{CH}_{4}$, methane; $\mathrm{mg} / \mathrm{L}$, milligrams per liter; $\mathrm{CO}_{2}$, carbon dioxide; $\mathrm{N}_{2}$, nitrogen gas; $\mathrm{O}_{2}$, oxygen gas; Ar, argon; cc STP/L, cubic centimeters at standard pressure and temperature per liter; temp, temperature; ${ }^{\circ} \mathrm{C}$, degrees Celsius; $\mathrm{CFC}$, chlorofluorocarbon; pptv, parts per trillion by volume; M, present but not quantified; \%, percent; ${ }^{3} \mathrm{H}$, tritium; TU, tritium units; $\mathrm{mg} / \mathrm{L}$, milligrams per liter; C, contaminated; >, greater than; --, not measured; na, not applicable]

\begin{tabular}{|c|c|c|c|c|c|c|c|c|c|c|c|c|}
\hline \multicolumn{4}{|c|}{ Site information } & \multicolumn{6}{|c|}{ CFCs and piston-flow model results } & \multirow[b]{2}{*}{$\begin{array}{c}{ }^{3} \mathbf{H} \\
\text { (TU) }\end{array}$} & \multirow[b]{2}{*}{$\begin{array}{c}\text { Dis- } \\
\text { solved } \\
\text { oxygen } \\
(\mathrm{mg} / \mathrm{L})\end{array}$} & \multirow[b]{2}{*}{ Comment } \\
\hline Aquifer & $\begin{array}{c}\text { USGS site } \\
\text { identification } \\
\text { number }\end{array}$ & $\begin{array}{l}\text { Local well } \\
\text { name } \\
\text { (final wells) }\end{array}$ & $\begin{array}{c}\text { Sample } \\
\text { date }\end{array}$ & $\begin{array}{c}\text { CFC-11, } \\
\text { atmospheric } \\
\text { mixing } \\
\text { ratio } \\
\text { (pptv) }\end{array}$ & $\begin{array}{c}\text { CFC-12, } \\
\text { atmospheric } \\
\text { mixing } \\
\text { ratio } \\
\text { (pptv) }\end{array}$ & $\begin{array}{c}\text { CFC-113, } \\
\text { atmospheric } \\
\text { mixing ratio } \\
\text { (pptv) }\end{array}$ & $\begin{array}{l}\text { Basis for } \\
\text { piston- } \\
\text { flow } \\
\text { model }\end{array}$ & $\begin{array}{l}\text { Piston- } \\
\text { flow } \\
\text { model } \\
\text { apparent } \\
\text { year of } \\
\text { recharge }\end{array}$ & $\begin{array}{l}\text { Piston- } \\
\text { flow } \\
\text { model } \\
\text { appar- } \\
\text { ent age } \\
\text { (years) }\end{array}$ & & & \\
\hline \multirow{5}{*}{ Arapahoe } & 395408104335301 & ARAPMAS 17 & $7 / 15 / 2005$ & 7.5 & 11.6 & 15.3 & CFC-12 & 1952 & 54 & $<0.2$ & 0.1 & $\begin{array}{l}\text { Age interpretation suspect } \\
\text { due to possible low-level } \\
\text { CFC contamination and } \\
\text { (or) degradation. }\end{array}$ \\
\hline & 394618104184201 & ARAPMAS 20 & $7 / 19 / 2005$ & 9.2 & 17.9 & 11.6 & CFC-12 & 1955 & 51 & $<0.2$ & M & $\begin{array}{l}\text { Age interpretation suspect } \\
\text { due to possible low-level } \\
\text { CFC contamination and } \\
\text { (or) degradation. }\end{array}$ \\
\hline & 391834104205601 & ARAPMAS 22 & $7 / 1 / 2005$ & 7.6 & 6.8 & 3.3 & CFC-12 & 1950 & 56 & 0.1 & 0.1 & $\begin{array}{l}\text { Age interpretation suspect } \\
\text { due to possible low-level } \\
\text { CFC contamination and } \\
\text { (or) degradation. }\end{array}$ \\
\hline & 385059104231201 & ARAPMAS 24 & $10 / 1 / 2005$ & $\mathrm{C}(403.7)$ & 526.9 & 61.3 & CFC-12 & 1994 & 12 & 11.2 & 6.3 & \\
\hline & 390341104135001 & ARAPMAS 26 & $7 / 20 / 2005$ & 9.9 & 9.4 & 9.8 & CFC-12 & 1951 & 55 & $<0.2$ & 0.3 & $\begin{array}{l}\text { Age interpretation suspect } \\
\text { due to possible low-level } \\
\text { CFC contamination and } \\
\text { (or) degradation. }\end{array}$ \\
\hline \multirow{3}{*}{$\begin{array}{l}\text { Laramie- } \\
\text { Fox } \\
\text { Hills }\end{array}$} & 394748104112301 & LFHMAS 04 & $11 / 29 / 2005$ & 7.3 & 7.8 & 3.7 & CFC-12 & 1950 & 56 & $<0.2$ & 0.1 & $\begin{array}{l}\text { Age interpretation suspect } \\
\text { due to possible low-level } \\
\text { CFC contamination and } \\
\text { (or) degradation. }\end{array}$ \\
\hline & 393659104111801 & LFHMAS 05 & $11 / 17 / 2005$ & 3.4 & 8.2 & 3.3 & CFC-12 & 1950 & 55 & $<0.2$ & 0.0 & $\begin{array}{l}\text { Age interpretation suspect } \\
\text { due to possible low-level } \\
\text { CFC contamination and } \\
\text { (or) degradation. }\end{array}$ \\
\hline & 400607104503901 & LFHMAS 10 & $12 / 9 / 2005$ & 11.7 & 70.2 & 13.7 & $\begin{array}{l}\text { CFC-12 } \\
\text { (CFCs } \\
\text { possibly } \\
\text { degraded) }\end{array}$ & 1965 & 41 & $<0.2$ & 0.0 & $\begin{array}{l}\text { Unsuitable for age deter- } \\
\text { mination due to possible } \\
\text { CFC contamination and } \\
\text { (or) degradation. }\end{array}$ \\
\hline
\end{tabular}




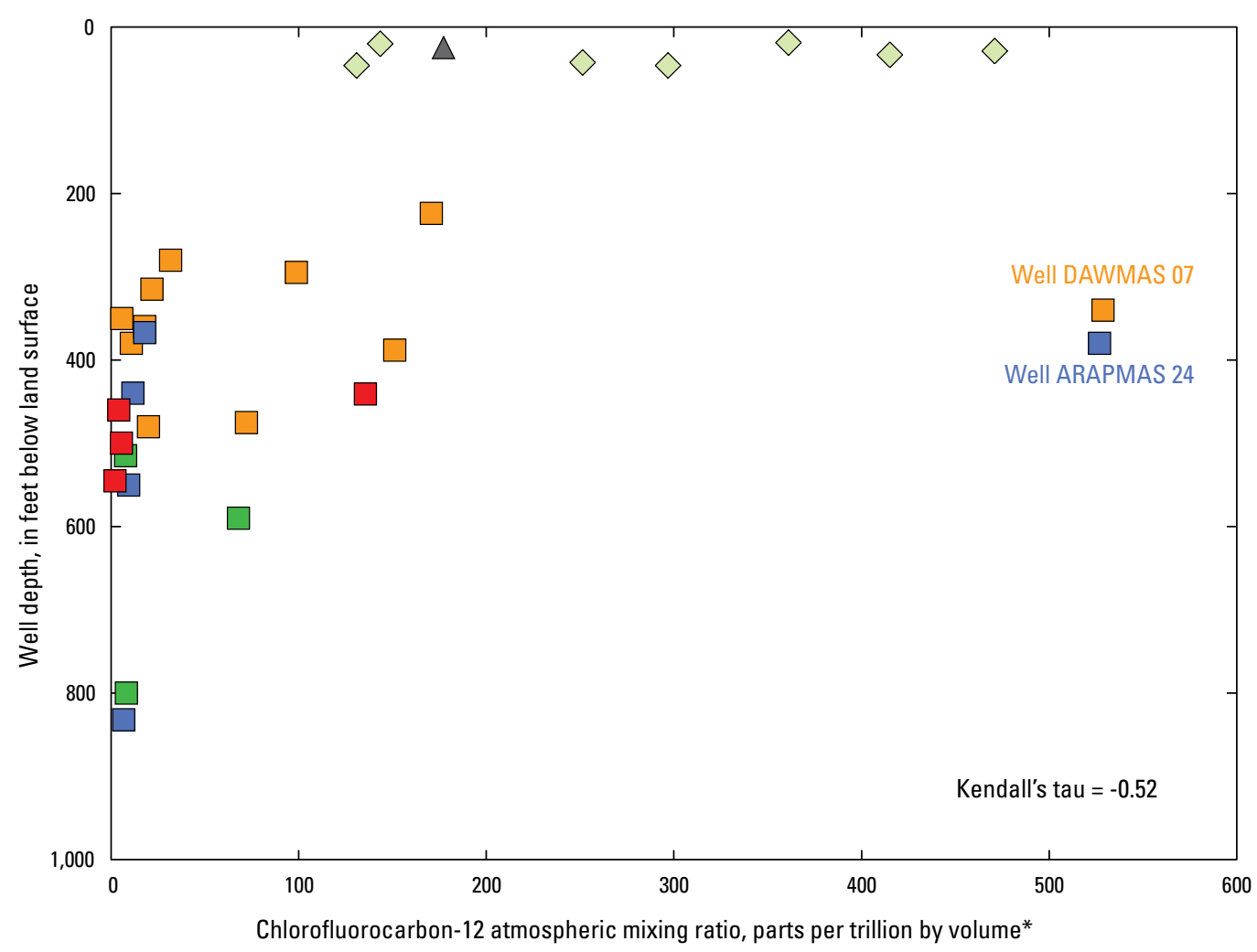

EXPLANATION

Water-table well, by land use

$\diamond$ Agricultural land use

$\triangle$ Urban land use

Bedrock-aquifer well, by aquifer

Dawson aquifer

Denver aquifer

Arapahoe aquifer

Laramie-Fox Hills aquifer

${ }^{*}$ Concentrations interpreted as contaminated are not included.

Figure 31. Relation between well depth and chlorofluorocarbon concentration (chlorofluorocarbon-12) for groundwater samples, Denver Basin aquifer system, Colorado, 2003-5.

Tritium and ${ }^{14} \mathrm{C}$ were the primary tracers used for age interpretations for the bedrock-aquifer samples. For some samples, the measured CFC concentration was greater than that which could result from atmospheric sources, which is indicative of sample contamination for the purpose of age interpretation. Contamination of one or more CFCs occurred in 8 samples, 6 of which were collected from urban landuse wells (table 10). CFCs have historically been used as refrigerants and for a variety of industrial applications, and the association between CFC contamination and urban land-use areas might reflect contamination of the shallow groundwater. One of these samples (collected from well URLUS 26; table 10) had contamination by all three CFCs, and an age could not be estimated, although the concentrations indicate that the groundwater is likely modern; this sample was categorized as young. Two samples (from wells URLUS 24 and LFHMAS 10; table 10) had evidence of CFC degradation, and the interpreted CFC ages are considered suspect; both samples were anoxic, and the LFHMAS 10 sample had the highest $\mathrm{CH}_{4}$ concentration measured in the study $(10.29 \mathrm{mg} / \mathrm{L}$; table 10), which might be indicative of methanogenic redox conditions, under which CFCs are likely to be degraded. High CFC concentrations for two bedrock-aquifer samples (from wells DAWMAS 07 and ARAPMAS 24; fig. 31) relative to other samples from the bedrock aquifers are likely indicative of relatively young groundwater; high ${ }^{3} \mathrm{H}$ and ${ }^{14} \mathrm{C}$ concentrations for these samples are consistent with this interpretation (fig. 32; table 10). 


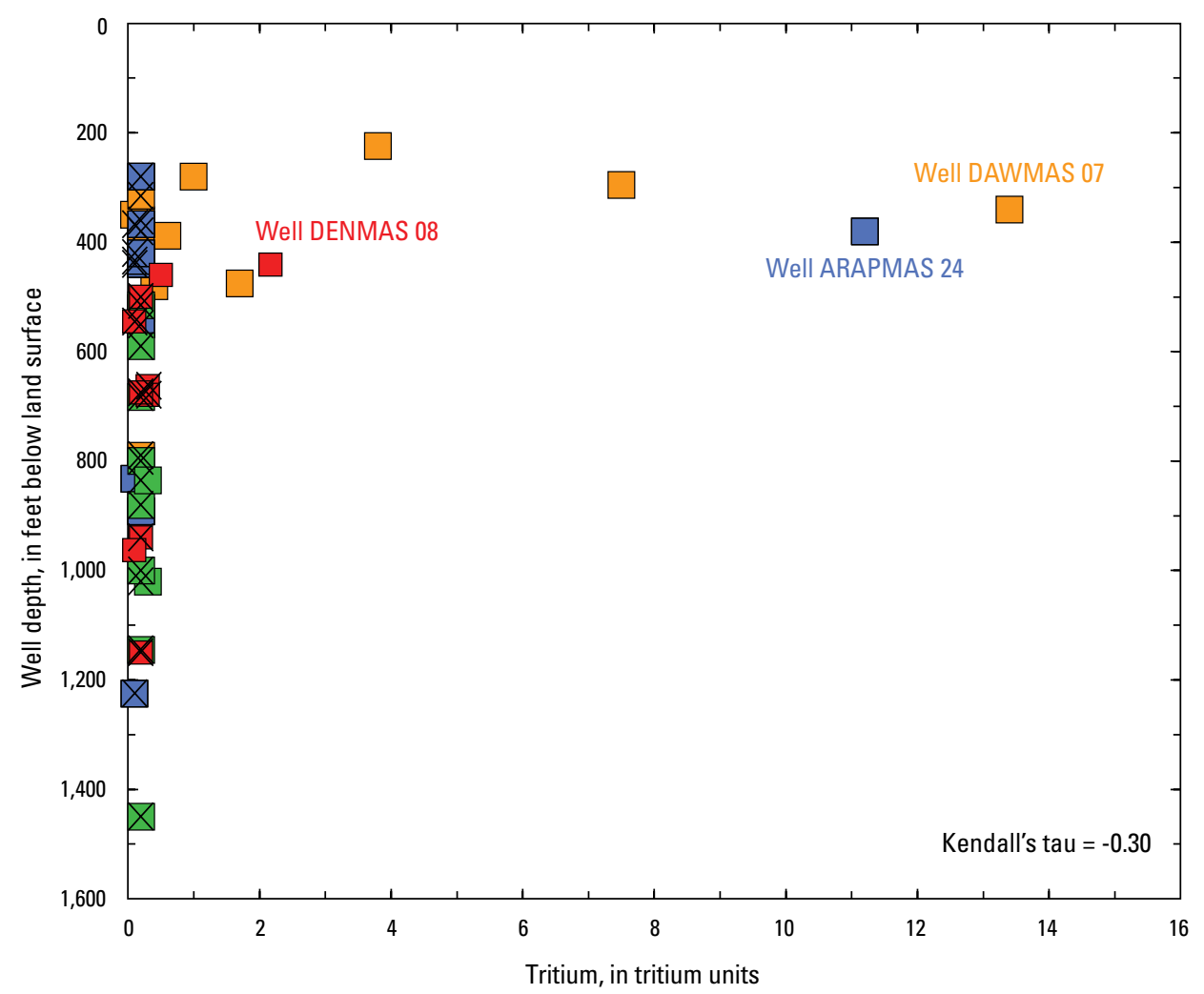

EXPLANATION

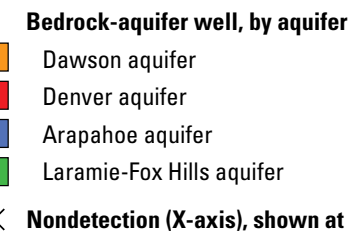

the laboratory reporting level

Figure 32. Relation between well depth and tritium concentration for groundwater samples, Denver Basin aquifer system, Colorado, 2003-5.

\section{Tritium}

Tritium concentrations were measured for selected bedrock-aquifer samples in conjunction with other age tracers (table 10). As noted earlier in the "Methods" section, a ${ }^{3} \mathrm{H}$ concentration greater than $0.3 \mathrm{TU}$ was considered to have at least a fraction of young water. Concentrations for samples from the bedrock aquifers ranged from $<0.1$ to $13.4 \mathrm{TU}$ (table 10). The median ${ }^{3} \mathrm{H}$ value for samples from the Dawson aquifer was $0.5 \mathrm{TU}$; median values for samples from the deeper Denver, Arapahoe, and Laramie-Fox Hills aquifers were less than the LRL $(<0.2 \mathrm{TU})$. Tritium concentrations generally decreased with well depth, with few detections in samples from the Denver, Arapahoe, and Laramie-Fox Hills aquifers (fig. 32). The mostly low and undetected (below LRLs) ${ }^{3} \mathrm{H}$ concentrations for samples from the deeper bedrock aquifers indicate that, with the exception of the Dawson aquifer, bedrock aquifer groundwater is mostly not affected by young recharge. Exceptions to this, such as samples from wells DENMAS 08 and ARAPMAS 24, with ${ }^{3} \mathrm{H}$ concentrations of 2.2 and $11.2 \mathrm{TU}$, respectively (table 10 ), are indicative of groundwater mixing with a component of young recharge water. For the Dawson aquifer, detectable ${ }^{3} \mathrm{H}$ concentrations greater than $0.3 \mathrm{TU}$ for many samples indicate that the Dawson aquifer is generally affected by mixing with a component of young groundwater (fig. 32). 


\section{Carbon-14 and Adjustment of Radiocarbon Ages}

The old fraction of recharge in the Denver Basin for selected samples from the bedrock aquifers was evaluated by using ${ }^{14} \mathrm{C}$ data (table 11). Unadjusted ${ }^{14} \mathrm{C}$ ages (table 11) are based on the radioactive decay of ${ }^{14} \mathrm{C}$ and are considered "raw" radiocarbon ages; although these unadjusted ages might represent if a groundwater sample contains a substantial fraction of old water, they do not account for uncertainties in ${ }^{14} \mathrm{C}$ dating and may not be an accurate estimate of the time of groundwater recharge. Carbon-14 groundwater ages were adjusted by using the computer program NetpathXL (Plummer and others, 1994; Parkhurst and Charlton, 2008), which corrects ${ }^{14} \mathrm{C}$ ages based on $\mathrm{C}$ mass transfers resulting from geochemical reactions. Carbon sources to groundwater systems that might alter the initial ${ }^{14} \mathrm{C}$ concentration and affect ${ }^{14} \mathrm{C}$ age interpretation include organic carbon, soil-gas $\mathrm{CO}_{2}$, and carbonate minerals. Model phases for mass-balance models using NetpathXL included carbon phases, gypsum, pyrite, and ion exchange processes; the constraints used in the mass-balance models included major-ion concentrations and the redox state of the water (specifically considering oxidation of organic matter, represented by lignite) (table 12).

NetpathXL requires definition of the ${ }^{14} \mathrm{C}$ activity at an initial point in the system ("initial well"), which is then adjusted to account for geochemical reactions occurring along a flow path to the point of measurement ("final well"). A relatively young, but ${ }^{3} \mathrm{H}$-free (prebomb pulse), water from upgradient portions of the aquifer is ideal for defining data for the initial well. For the bedrock aquifers, the initial well was selected on the basis of ${ }^{14} \mathrm{C}$ and ${ }^{3} \mathrm{H}$ concentrations and the relative position of the sampled well in the flow path. The sample collected from well DAWMAS 12 completed in the uppermost (Dawson) bedrock aquifer had the highest measured ${ }^{14} \mathrm{C}$ concentration $(85.5 \mathrm{pmC})$ for ${ }^{3} \mathrm{H}$-free (that is, ${ }^{3} \mathrm{H}<\mathrm{LRL}$ ) groundwater samples from the bedrock aquifers (table 11). Well DAWMAS 12 is near aquifer recharge areas around the Palmer Divide. As a result of these factors, DAWMAS 12 was selected as the initial well for ${ }^{14} \mathrm{C}$ modeling.

The ${ }^{14} \mathrm{C}$ ages were not adjusted for some samples analyzed for ${ }^{14} \mathrm{C}$. Samples with very low concentrations of ${ }^{14} \mathrm{C}(<0.05 \mathrm{pmC})$ and no detected ${ }^{3} \mathrm{H}$ were categorized as old and not modeled; specific ages were not resolvable within the range of the ${ }^{14} \mathrm{C}$ dating method $(<30,000$ years). Several samples from the bedrock aquifers had ${ }^{14} \mathrm{C}$ concentrations yielding unadjusted ages of greater than 1,000 years yet contained ${ }^{3} \mathrm{H}$ at a higher concentration than likely for water recharged prior to the 1950s ( $>0.3 \mathrm{TU})$; these samples were collected from wells DAWMAS 10, DAWMAS 13, DAWMAS 27, DAWMAS 28, and DENMAS 04 (table 11). These results indicate that these samples contain at least a component of post-1950s water, and they were categorized as mixed. Samples collected from two wells (DAWMAS 07 and ARAPMAS 24) had elevated ${ }^{14} \mathrm{C}$ concentrations ( $>100$ $\mathrm{pmC}$ ) and relatively high ${ }^{3} \mathrm{H}$ concentrations, indicative of young (modern) groundwater; these samples were categorized as young, which is also consistent with CFC results for these samples (fig. 31). 
Table 11. Summary of carbon-14 age-tracer data and modeled age adjustments for groundwater samples, Denver Basin aquifer system, Colorado, 2003-5.

[USGS, U.S. Geological Survey; ${ }^{3} \mathrm{H}$, tritium; TU, tritium units; ${ }^{14} \mathrm{C}$, carbon-14; pmC, percent modern carbon; $\delta^{13} \mathrm{C}$, delta carbon-13; $\mathrm{CO}_{2}$, carbon dioxide; BP, before present; Mg, magnesium; Na, sodium; $\mathrm{mmol} / \mathrm{kg}$, millimoles per kilogram; <, less than; >, greater than; na, not applicable or no Netpath model; --, no phase transfer in modeled solution; $\mathrm{A}_{0}$, initial ${ }^{14} \mathrm{C}$ activity (pmC) of groundwater when recharged; well name in bold used as initial well; $\mathrm{Ca}$, calcium]

\begin{tabular}{|c|c|c|c|c|c|c|c|c|c|c|c|c|}
\hline \multicolumn{4}{|c|}{ Site information } & \multicolumn{5}{|c|}{ Measured ${ }^{3} \mathrm{H}$ and ${ }^{14} \mathrm{C}$ data ${ }^{1}$} & \multicolumn{4}{|c|}{ Netpath adjusted ${ }^{14} \mathrm{C}$ results ${ }^{2,3}$} \\
\hline Aquifer & $\begin{array}{c}\text { USGS site } \\
\text { identification } \\
\text { number }\end{array}$ & $\begin{array}{l}\text { Local well } \\
\text { name } \\
\text { (final well) }\end{array}$ & $\begin{array}{c}\text { Sample } \\
\text { date }\end{array}$ & $\begin{array}{l}{ }^{3} \mathrm{H}, \\
\text { TU }\end{array}$ & $\begin{array}{c}{ }^{14} \mathrm{C} \\
(\mathrm{pmC})\end{array}$ & $\begin{array}{c}{ }^{14} \mathrm{C} \\
\text { counting } \\
\text { error } \\
\text { (pmC) }\end{array}$ & $\begin{array}{c}\delta^{13} \mathrm{C}, \\
\text { per mil, } \\
\text { measured }\end{array}$ & $\begin{array}{c}\text { Unadjusted } \\
{ }^{14} C \text { age, } \\
\text { years BP } \\
\left(A_{0}=100\right)\end{array}$ & $\begin{array}{c}\text { Initial } \\
\text { well }\end{array}$ & $\begin{array}{c}\text { Adjusted }{ }^{14} \mathrm{C} \\
\text { age, years } \\
\text { (Netpath) }^{4}\end{array}$ & $\begin{array}{c}\text { Adjusted }{ }^{14} \mathrm{C} \\
\text { age, years } \\
\text { (Netpath) } \\
\left(A_{0}=100\right)\end{array}$ & $\begin{array}{c}\delta^{13} \mathrm{C}, \text { per } \\
\text { mil, mod- } \\
\text { eled, with } \\
\text { Rayleigh } \\
\text { fractionation }\end{array}$ \\
\hline \multirow{9}{*}{ Dawson } & 393226104490101 & DAWMAS 07 & $12 / 10 / 2004$ & 13.4 & 104 & 0.5 & -13.41 & 0 & na & na & na & na \\
\hline & 392339104482601 & DAWMAS 09 & $12 / 7 / 2004$ & $<0.2$ & 10.2 & 0.12 & -14.19 & 18,000 & DAWMAS12 & 14,000 & 15,000 & -13.85 \\
\hline & 391605104475001 & DAWMAS 10 & $1 / 20 / 2005$ & 3.8 & 84.3 & 0.34 & -12.88 & 1,000 & na & na & na & na \\
\hline & 390342104464401 & DAWMAS 12 & $12 / 9 / 2004$ & $<0.2$ & 85.5 & 0.42 & -18.95 & 1,000 & DAWMAS12 & $<1,000$ & 1,000 & -18.95 \\
\hline & 385758104414801 & DAWMAS 13 & $12 / 13 / 2005$ & 1.0 & 34.1 & 0.13 & -15.65 & 9,000 & DAWMAS12 & na & na & na \\
\hline & 390717104400401 & DAWMAS 14 & $11 / 30 / 2004$ & 0.1 & 16.0 & 0.15 & -14.18 & 15,000 & DAWMAS12 & 9,000 & 11,000 & -14.22 \\
\hline & 392727104385201 & DAWMAS 17 & $12 / 28 / 2004$ & 7.5 & 88.7 & 0.53 & -10.37 & 1,000 & na & na & na & na \\
\hline & 391148104294101 & DAWMAS 27 & $12 / 8 / 2004$ & 1.7 & 75.2 & 0.4 & -12.52 & 2,000 & na & na & na & na \\
\hline & 391848104261401 & DAWMAS 28 & $12 / 14 / 2004$ & 0.6 & 81.9 & 0.37 & -9.66 & 2,000 & na & na & na & na \\
\hline \multirow{8}{*}{ Denver } & 392559104415201 & DENMAS 01 & $8 / 25 / 2005$ & $<0.2$ & 0.0 & 0.05 & -11.73 & $>30,000$ & na & na & na & na \\
\hline & 394134104305701 & DENMAS 02 & $9 / 8 / 2005$ & $<0.3$ & 0.4 & 0.05 & -10.60 & 44,000 & DAWMAS12 & $>30,000$ & $>30,000$ & -10.66 \\
\hline & 390226104134801 & DENMAS 03 & $9 / 13 / 2005$ & $<0.3$ & 13.9 & 0.07 & -5.92 & 16,000 & DAWMAS12 & 8,000 & 9,000 & -6.02 \\
\hline & 385816104411201 & DENMAS 04 & $10 / 1 / 2005$ & 0.5 & 16.3 & 0.08 & -13.07 & 15,000 & na & na & na & na \\
\hline & 391851104204501 & DENMAS 05 & $12 / 29 / 2005$ & $<0.1$ & 0.0 & 0.05 & -9.10 & $>30,000$ & na & na & na & na \\
\hline & 390534104465501 & DENMAS 07 & $10 / 25 / 2005$ & $<0.2$ & 2.5 & 0.06 & -10.27 & 30,000 & DAWMAS12 & 24,000 & 25,000 & -10.44 \\
\hline & 393304104444201 & DENMAS 09 & $10 / 25 / 2005$ & $<0.2$ & 0.8 & 0.05 & -12.17 & 39,000 & DAWMAS12 & $>30,000$ & $>30,000$ & -12.15 \\
\hline & 390243104481401 & DENMAS 10 & $12 / 1 / 2005$ & $<0.2$ & 11.5 & 0.09 & -11.15 & 17,000 & DAWMAS12 & 12,000 & 13,000 & -11.04 \\
\hline
\end{tabular}


Table 11. Summary of carbon-14 age-tracer data and modeled age adjustments for groundwater samples, Denver Basin aquifer system, Colorado, 2003-5.-Continued

[USGS, U.S. Geological Survey; ${ }^{3} \mathrm{H}$, tritium; TU, tritium units; ${ }^{14} \mathrm{C}$, carbon-14; pmC, percent modern carbon; $\delta^{13} \mathrm{C}$, delta carbon-13; $\mathrm{CO}_{2}$, carbon dioxide; $\mathrm{BP}$, before present; $\mathrm{Mg}$, magnesium; $\mathrm{Na}$, sodium; $\mathrm{mmol} / \mathrm{kg}$, millimoles per kilogram; <, less than; >, greater than; na, not applicable or no Netpath model; --, no phase transfer in modeled solution; $\mathrm{A}_{0}$, initial ${ }^{14} \mathrm{C}$ activity (pmC) of groundwater when recharged; well name in bold used as initial well; Ca, calcium]

\begin{tabular}{|c|c|c|c|c|c|c|c|c|c|c|c|c|}
\hline \multicolumn{4}{|c|}{ Site information } & \multicolumn{5}{|c|}{ Measured ${ }^{3} \mathrm{H}$ and ${ }^{14} \mathrm{C}$ data ${ }^{1}$} & \multicolumn{4}{|c|}{ Netpath adjusted ${ }^{14} \mathrm{C}$ results ${ }^{2,3}$} \\
\hline Aquifer & $\begin{array}{c}\text { USGS site } \\
\text { identification } \\
\text { number }\end{array}$ & $\begin{array}{l}\text { Local well } \\
\text { name } \\
\text { (final well) }\end{array}$ & $\begin{array}{c}\text { Sample } \\
\text { date }\end{array}$ & $\begin{array}{l}{ }^{3} \mathrm{H}, \\
\text { TU }\end{array}$ & $\begin{array}{c}{ }^{14} \mathrm{C} \\
(\mathrm{pmC})\end{array}$ & $\begin{array}{c}{ }^{14} \mathrm{C} \\
\text { counting } \\
\text { error } \\
\text { (pmC) }\end{array}$ & $\begin{array}{c}\delta^{13} \mathrm{C} \\
\text { per mil, } \\
\text { measured }\end{array}$ & $\begin{array}{l}\text { Unadjusted } \\
{ }^{14} \mathrm{C} \text { age, } \\
\text { years } \mathrm{BP} \\
\left(A_{0}=100\right)\end{array}$ & $\begin{array}{c}\text { Initial } \\
\text { well }\end{array}$ & $\begin{array}{c}\text { Adjusted }{ }^{14} \mathrm{C} \\
\text { age, years } \\
\text { (Netpath) }^{4}\end{array}$ & $\begin{array}{c}\text { Adjusted }{ }^{14} \mathrm{C} \\
\text { age, years } \\
\text { (Netpath) } \\
\left(A_{0}=100\right)\end{array}$ & $\begin{array}{c}\delta^{13} \mathrm{C}, \text { per } \\
\text { mil, mod- } \\
\text { eled, with } \\
\text { Rayleigh } \\
\text { fractionation }\end{array}$ \\
\hline \multirow{12}{*}{ Arapahoe } & 385646104504601 & ARAPMAS 01 & $7 / 5 / 2005$ & $<0.2$ & 14.6 & 0.14 & -10.60 & 15,000 & DAWMAS12 & 9,000 & 10,000 & -10.68 \\
\hline & 393747104493501 & ARAPMAS 03 & $7 / 21 / 2005$ & $<0.1$ & 0.0 & 0.05 & -12.78 & $>30,000$ & na & na & na & na \\
\hline & 395841104510901 & ARAPMAS 06 & $7 / 13 / 2005$ & $<0.2$ & 0.0 & 0.05 & -8.02 & $>30,000$ & na & na & na & na \\
\hline & 394058104312101 & ARAPMAS 16 & $8 / 1 / 2005$ & $<0.2$ & 0.0 & 0.05 & -10.14 & $>30,000$ & na & na & na & na \\
\hline & 395408104335301 & ARAPMAS 17 & $7 / 15 / 2005$ & $<0.2$ & 0.6 & 0.06 & -13.82 & $>30,000$ & DAWMAS12 & 28,000 & 30,000 & -13.72 \\
\hline & 400202104335801 & ARAPMAS 18 & $7 / 22 / 2005$ & $<0.2$ & 11.6 & 0.11 & -11.51 & 17,000 & DAWMAS12 & 12,000 & 12,000 & -11.46 \\
\hline & 394618104184201 & ARAPMAS 20 & $7 / 19 / 2005$ & $<0.2$ & 11.1 & 0.09 & -7.59 & 18,000 & DAWMAS12 & 10,000 & 11,000 & -7.56 \\
\hline & 391834104205601 & ARAPMAS 22 & $7 / 1 / 2005$ & 0.1 & 0.0 & 0.05 & -7.68 & $>30,000$ & na & na & na & na \\
\hline & 385059104231201 & ARAPMAS 24 & $10 / 1 / 2005$ & 11.2 & 106 & 0.32 & -7.43 & 0 & na & na & na & na \\
\hline & 390341104135001 & ARAPMAS 26 & $7 / 20 / 2005$ & $<0.2$ & 5.2 & 0.08 & -5.29 & 24,000 & DAWMAS12 & 16,000 & 17,000 & -5.58 \\
\hline & 392400104150601 & ARAPMAS 28 & $7 / 14 / 2005$ & $<0.2$ & 2.5 & 0.06 & -10.68 & 30,000 & DAWMAS12 & 25,000 & 25,000 & -10.97 \\
\hline & 393617104131101 & ARAPMAS 29 & $6 / 29 / 2005$ & $<0.2$ & 2.6 & 0.07 & -11.69 & 29,000 & DAWMAS12 & 24,000 & 25,000 & -11.75 \\
\hline \multirow{10}{*}{$\begin{array}{l}\text { Laramie- } \\
\text { Fox Hills }\end{array}$} & 400111104354501 & LFHMAS 01 & $10 / 26 / 2005$ & $<0.3$ & 0.0 & 0.05 & -4.42 & $>30,000$ & na & na & na & na \\
\hline & 395911104505901 & LFHMAS 02 & $12 / 6 / 2005$ & $<0.2$ & 0.0 & 0.05 & -12.08 & $>30,000$ & na & na & na & na \\
\hline & 385056104231901 & LFHMAS 03 & $11 / 18 / 2005$ & $<0.2$ & 0.0 & 0.05 & -16.05 & $>30,000$ & na & na & na & na \\
\hline & 394748104112301 & LFHMAS 04 & $11 / 29 / 2005$ & $<0.2$ & 0.0 & 0.05 & -8.51 & $>30,000$ & na & na & na & na \\
\hline & 393659104111801 & LFHMAS 05 & $11 / 17 / 2005$ & $<0.2$ & 0.0 & 0.05 & -7.95 & $>30,000$ & na & na & na & na \\
\hline & 385622104461201 & LFHMAS 06 & $12 / 15 / 2005$ & $<0.2$ & 1.2 & 0.05 & -12.99 & $>30,000$ & DAWMAS12 & $>30,000$ & $>30,000$ & -12.79 \\
\hline & 385036104364101 & LFHMAS 07 & $11 / 15 / 2005$ & $<0.3$ & 4.8 & 0.06 & -13.71 & 24,000 & DAWMAS12 & 18,000 & 19,000 & -13.56 \\
\hline & 390707104053001 & LFHMAS 08 & $11 / 16 / 2005$ & $<0.2$ & 10.9 & 0.07 & -9.14 & 18,000 & DAWMAS12 & 12,000 & 13,000 & -9.22 \\
\hline & 393114105025801 & LFHMAS 09 & $12 / 13 / 2005$ & $<0.2$ & 0.0 & 0.05 & -19.06 & $>30,000$ & na & na & na & na \\
\hline & 400607104503901 & LFHMAS 10 & $12 / 9 / 2005$ & $<0.2$ & 0.1 & 0.05 & -9.38 & $>30,000$ & DAWMAS12 & $>30,000$ & $>30,000$ & -9.29 \\
\hline
\end{tabular}


Table 11. Summary of carbon-14 age-tracer data and modeled age adjustments for groundwater samples, Denver Basin aquifer system, Colorado, 2003-5.-Continued

[USGS, U.S. Geological Survey; ${ }^{3} \mathrm{H}$, tritium; TU, tritium units; ${ }^{14} \mathrm{C}$, carbon-14; pmC, percent modern carbon; $\delta^{13} \mathrm{C}$, delta carbon-13; $\mathrm{CO}_{2}$, carbon dioxide; BP, before present; Mg, magnesium; Na, sodium; $\mathrm{mmol} / \mathrm{kg}$, millimoles per kilogram; <, less than; >, greater than; na, not applicable or no Netpath model; --, no phase transfer in modeled solution; $\mathrm{A}_{0}$, initial ${ }^{14} \mathrm{C}$ activity (pmC) of groundwater when recharged; well name in bold used as initial well; $\mathrm{Ca}$, calcium]

\begin{tabular}{|c|c|c|c|c|c|c|c|c|c|c|c|c|c|}
\hline \multicolumn{4}{|c|}{ Site information } & \multicolumn{10}{|c|}{ Mass transfer of phases calculated by using Netpath $\left(\mathrm{mmol} / \mathrm{kg}\right.$ water) ${ }^{5}$} \\
\hline Aquifer & $\begin{array}{c}\text { USGS site } \\
\text { identification } \\
\text { number }\end{array}$ & $\begin{array}{l}\text { Local well } \\
\text { name } \\
\text { (final well) }\end{array}$ & $\begin{array}{c}\text { Sample } \\
\text { date }\end{array}$ & Calcite & $\begin{array}{c}\text { Calcite } \\
\text { isotopic } \\
\text { exchange }\end{array}$ & Lignite & Dolomite & Gypsum & $\mathrm{CO}_{2}$ gas & Exchange $^{6}$ & $\begin{array}{c}\mathrm{Mg} / \mathrm{Na} \\
\text { exchange }\end{array}$ & Pyrite & $\begin{array}{l}\text { Silica } \\
\left(\mathrm{SiO}_{2}\right)\end{array}$ \\
\hline \multirow{9}{*}{ Dawson } & 393226104490101 & DAWMAS 07 & $12 / 10 / 2004$ & na & na & na & na & na & na & na & na & na & na \\
\hline & 392339104482601 & DAWMAS 09 & $12 / 7 / 2004$ & 1.01 & -- & 0.05 & 0.04 & 0.49 & 0.40 & 0.85 & -- & -- & -0.42 \\
\hline & 391605104475001 & DAWMAS 10 & $1 / 20 / 2005$ & na & na & na & na & na & na & na & na & na & na \\
\hline & 390342104464401 & DAWMAS 12 & $12 / 9 / 2004$ & -- & -- & -- & -- & -- & -- & -- & -- & -- & -- \\
\hline & 385758104414801 & DAWMAS 13 & $12 / 13 / 2005$ & na & na & na & na & na & na & na & na & na & na \\
\hline & 390717104400401 & DAWMAS 14 & $11 / 30 / 2004$ & -- & -- & 0.45 & 0.13 & 0.39 & -0.72 & 0.19 & -- & -0.13 & -0.05 \\
\hline & 392727104385201 & DAWMAS 17 & $12 / 28 / 2004$ & na & na & na & na & na & na & na & na & na & na \\
\hline & 391148104294101 & DAWMAS 27 & $12 / 8 / 2004$ & na & na & na & na & na & na & na & na & na & na \\
\hline & 391848104261401 & DAWMAS 28 & $12 / 14 / 2004$ & na & na & na & na & na & na & na & na & na & na \\
\hline \multirow{8}{*}{ Denver } & 392559104415201 & DENMAS 01 & $8 / 25 / 2005$ & na & na & na & na & na & na & na & na & na & na \\
\hline & 394134104305701 & DENMAS 02 & $9 / 8 / 2005$ & 1.11 & -- & 0.07 & -- & 0.16 & -- & 1.28 & 0.03 & 0.03 & -0.45 \\
\hline & 390226104134801 & DENMAS 03 & $9 / 13 / 2005$ & 1.02 & 0.60 & -- & -- & 0.04 & 0.14 & 1.20 & 0.05 & 0.05 & -0.43 \\
\hline & 385816104411201 & DENMAS 04 & $10 / 1 / 2005$ & na & na & na & na & na & na & na & na & na & na \\
\hline & 391851104204501 & DENMAS 05 & $12 / 29 / 2005$ & na & na & na & na & na & na & na & na & na & na \\
\hline & 390534104465501 & DENMAS 07 & $10 / 25 / 2005$ & 0.84 & 0.20 & 0.16 & 0.04 & 0.07 & 0.11 & 0.57 & -- & -- & -0.41 \\
\hline & 393304104444201 & DENMAS 09 & $10 / 25 / 2005$ & 0.96 & -- & 0.15 & 0.05 & 0.25 & 0.23 & 0.81 & -- & -- & -0.44 \\
\hline & 390243104481401 & DENMAS 10 & $12 / 1 / 2005$ & 0.53 & 0.20 & 0.15 & 0.17 & 0.62 & 0.16 & 0.39 & -- & -- & -0.50 \\
\hline
\end{tabular}


Table 11. Summary of carbon-14 age-tracer data and modeled age adjustments for groundwater samples, Denver Basin aquifer system, Colorado, 2003-5.-Continued

[USGS, U.S. Geological Survey; ${ }^{3} \mathrm{H}$, tritium; TU, tritium units; ${ }^{14} \mathrm{C}$, carbon-14; pmC, percent modern carbon; $\delta^{13} \mathrm{C}$, delta carbon-13; $\mathrm{CO}_{2}$, carbon dioxide; BP, before present; Mg, magnesium; Na, sodium; $\mathrm{mmol} / \mathrm{kg}$, millimoles per kilogram; <, less than; >, greater than; na, not applicable or no Netpath model; --, no phase transfer in modeled solution; $\mathrm{A}_{0}$, initial ${ }^{14} \mathrm{C}$ activity (pmC) of groundwater when recharged; well name in bold used as initial well; Ca, calcium]

\begin{tabular}{|c|c|c|c|c|c|c|c|c|c|c|c|c|c|}
\hline \multicolumn{4}{|c|}{ Site information } & \multicolumn{10}{|c|}{ Mass transfer of phases calculated by using Netpath (mmol/kg water) ${ }^{5}$} \\
\hline Aquifer & $\begin{array}{c}\text { USGS site } \\
\text { identification } \\
\text { number }\end{array}$ & $\begin{array}{l}\text { Local well } \\
\text { name } \\
\text { (final well) }\end{array}$ & $\begin{array}{c}\text { Sample } \\
\text { date }\end{array}$ & Calcite & $\begin{array}{c}\text { Calcite } \\
\text { isotopic } \\
\text { exchange }\end{array}$ & Lignite & Dolomite & Gypsum & $\mathrm{CO}_{2}$ gas & Exchange $^{6}$ & $\begin{array}{c}\mathrm{Mg} / \mathrm{Na} \\
\text { exchange }\end{array}$ & Pyrite & $\begin{array}{l}\text { Silica } \\
\left(\mathrm{SiO}_{2}\right)\end{array}$ \\
\hline \multirow{12}{*}{ Arapahoe } & 385646104504601 & ARAPMAS 01 & $7 / 5 / 2005$ & 0.99 & 0.30 & 0.16 & -- & 5.25 & 0.29 & 2.22 & -1.76 & -- & -0.47 \\
\hline & 393747104493501 & ARAPMAS 03 & $7 / 21 / 2005$ & na & na & na & na & na & na & na & na & na & na \\
\hline & 395841104510901 & ARAPMAS 06 & $7 / 13 / 2005$ & na & na & na & na & na & na & na & na & na & na \\
\hline & 394058104312101 & ARAPMAS 16 & $8 / 1 / 2005$ & na & na & na & na & na & na & na & na & na & na \\
\hline & 395408104335301 & ARAPMAS 17 & $7 / 15 / 2005$ & -- & -- & 2.53 & 0.03 & 7.48 & -1.62 & 7.05 & -- & -0.87 & -0.50 \\
\hline & 400202104335801 & ARAPMAS 18 & $7 / 22 / 2005$ & 1.18 & -- & 0.14 & 0.42 & 5.43 & 0.92 & 5.14 & 0.59 & -- & -0.50 \\
\hline & 394618104184201 & ARAPMAS 20 & $7 / 19 / 2005$ & 1.73 & 0.60 & 0.17 & -- & 0.32 & 0.70 & 2.07 & 0.02 & -- & -0.49 \\
\hline & 391834104205601 & ARAPMAS 22 & $7 / 1 / 2005$ & na & na & na & na & na & na & na & na & na & na \\
\hline & 385059104231201 & ARAPMAS 24 & $10 / 1 / 2005$ & na & na & na & na & na & na & na & na & na & na \\
\hline & 390341104135001 & ARAPMAS 26 & $7 / 20 / 2005$ & 1.53 & 0.60 & 0.07 & -- & -- & 0.27 & 1.68 & 0.05 & 0.04 & -0.50 \\
\hline & 392400104150601 & ARAPMAS 28 & $7 / 14 / 2005$ & 0.89 & 0.20 & 0.16 & 0.21 & 6.21 & 0.76 & 5.81 & -- & -- & -0.51 \\
\hline & 393617104131101 & ARAPMAS 29 & $6 / 29 / 2005$ & -- & -- & 0.16 & 0.78 & 2.97 & 0.44 & 3.66 & 0.80 & -- & -0.50 \\
\hline \multirow{10}{*}{$\begin{array}{l}\text { Laramie- } \\
\text { Fox Hills }\end{array}$} & 400111104354501 & LFHMAS 01 & $10 / 26 / 2005$ & na & na & na & na & na & na & na & na & na & na \\
\hline & 395911104505901 & LFHMAS 02 & $12 / 6 / 2005$ & na & na & na & na & na & na & na & na & na & na \\
\hline & 385056104231901 & LFHMAS 03 & $11 / 18 / 2005$ & na & na & na & na & na & na & na & na & na & na \\
\hline & 394748104112301 & LFHMAS 04 & $11 / 29 / 2005$ & na & na & na & na & na & na & na & na & na & na \\
\hline & 393659104111801 & LFHMAS 05 & $11 / 17 / 2005$ & na & na & na & na & na & na & na & na & na & na \\
\hline & 385622104461201 & LFHMAS 06 & $12 / 15 / 2005$ & 0.29 & 0.10 & 0.02 & 0.06 & -- & -0.17 & 0.05 & -- & 0.05 & -0.46 \\
\hline & 385036104364101 & LFHMAS 07 & $11 / 15 / 2005$ & -- & -- & 1.12 & -- & 5.11 & -0.88 & 4.77 & 0.04 & -0.35 & -0.50 \\
\hline & 390707104053001 & LFHMAS 08 & $11 / 16 / 2005$ & 1.00 & -- & -- & -- & 0.07 & -0.02 & 1.24 & 0.05 & 0.06 & -0.44 \\
\hline & 393114105025801 & LFHMAS 09 & $12 / 13 / 2005$ & na & na & na & na & na & na & na & na & na & na \\
\hline & 400607104503901 & LFHMAS 10 & $12 / 9 / 2005$ & -- & na & 1.37 & 2.33 & -- & 1.83 & 2.48 & 2.38 & -0.02 & -0.50 \\
\hline
\end{tabular}


Table 11. Summary of carbon-14 age-tracer data and modeled age adjustments for groundwater samples, Denver Basin aquifer system, Colorado, 2003-5.-Continued

[USGS, U.S. Geological Survey; ${ }^{3} \mathrm{H}$, tritium; TU, tritium units; ${ }^{14} \mathrm{C}$, carbon-14; pmC, percent modern carbon; $\delta^{13} \mathrm{C}$, delta carbon-13; $\mathrm{CO}_{2}$, carbon dioxide; $\mathrm{BP}$, before present; $\mathrm{Mg}$, magnesium; $\mathrm{Na}$, sodium; mmol/ $\mathrm{kg}$, millimoles per kilogram; <, less than; >, greater than; na, not applicable or no Netpath model; --, no phase transfer in modeled solution; $\mathrm{A}_{0}$, initial ${ }^{14} \mathrm{C}$ activity (pmC) of groundwater when recharged; well name in bold used as initial well; $\mathrm{Ca}$, calcium]

\begin{tabular}{|c|c|c|c|c|c|c|c|}
\hline \multicolumn{4}{|c|}{ Site information } & \multicolumn{3}{|c|}{ Saturation indices } & \multirow[b]{2}{*}{ Comment } \\
\hline Aquifer & $\begin{array}{c}\text { USGS site } \\
\text { identification } \\
\text { number }\end{array}$ & $\begin{array}{c}\text { Local well } \\
\text { name } \\
\text { (final well) }\end{array}$ & $\begin{array}{l}\text { Sample } \\
\text { date }\end{array}$ & Calcite & Dolomite & Gypsum & \\
\hline \multirow{9}{*}{ Dawson } & 393226104490101 & DAWMAS 07 & $12 / 10 / 2004$ & -0.2 & -1.1 & -1.4 & Not modeled based on ${ }^{3} \mathrm{H}$ and ${ }^{14} \mathrm{C}$ concentrations. \\
\hline & 392339104482601 & DAWMAS 09 & $12 / 7 / 2004$ & 0.1 & -0.8 & -2.1 & $\begin{array}{l}\text { Netpath used to estimate alkalinity concentration (based on charge } \\
\text { balance). }\end{array}$ \\
\hline & 391605104475001 & DAWMAS 10 & $1 / 20 / 2005$ & -1.7 & -4.3 & -2.8 & Not modeled based on ${ }^{3} \mathrm{H}$ concentration. \\
\hline & 390342104464401 & DAWMAS 12 & $12 / 9 / 2004$ & -2.7 & -6.1 & -3.8 & $\begin{array}{l}\text { Considered as initial and final well; age model results range from } \\
0 \text { years (based on measured } A_{0} \text { ) to } 1,000 \text { years (based on } A_{0}=100 \text { ). }\end{array}$ \\
\hline & 385758104414801 & DAWMAS 13 & $12 / 13 / 2005$ & -1.2 & -3.5 & -1 & Not modeled based on measured ${ }^{3} \mathrm{H}$ concentration. \\
\hline & 390717104400401 & DAWMAS 14 & $11 / 30 / 2004$ & -0.9 & -2.6 & -2.6 & \\
\hline & 392727104385201 & DAWMAS 17 & $12 / 28 / 2004$ & -1.0 & -2.7 & -2.5 & Not modeled based on ${ }^{3} \mathrm{H}$ concentration. \\
\hline & 391148104294101 & DAWMAS 27 & $12 / 8 / 2004$ & -1.7 & -4 & -3.1 & Not modeled based on ${ }^{3} \mathrm{H}$ concentration. \\
\hline & 391848104261401 & DAWMAS 28 & $12 / 14 / 2004$ & -1.0 & -2.6 & -2.7 & Not modeled based on ${ }^{3} \mathrm{H}$ concentration. \\
\hline \multirow{8}{*}{ Denver } & 392559104415201 & DENMAS 01 & $8 / 25 / 2005$ & -0.30 & -1.40 & -2.70 & Not modeled based on low $(<0.1 \mathrm{pmC})$ or no ${ }^{14} \mathrm{C}$. \\
\hline & 394134104305701 & DENMAS 02 & $9 / 8 / 2005$ & 0.70 & 0.60 & -3.10 & \\
\hline & 390226104134801 & DENMAS 03 & $9 / 13 / 2005$ & -0.20 & -1.10 & -3.90 & \\
\hline & 385816104411201 & DENMAS 04 & $10 / 1 / 2005$ & -0.8 & -2.7 & -2.4 & Not modeled based on ${ }^{3} \mathrm{H}$ concentration. \\
\hline & 391851104204501 & DENMAS 05 & $12 / 29 / 2005$ & -0.03 & -0.80 & -2.50 & Not modeled based on low $(<0.1 \mathrm{pmC})$ or no ${ }^{14} \mathrm{C}$. \\
\hline & 390534104465501 & DENMAS 07 & $10 / 25 / 2005$ & -0.05 & -0.90 & -2.90 & \\
\hline & 393304104444201 & DENMAS 09 & $10 / 25 / 2005$ & -0.10 & -1.00 & -2.50 & \\
\hline & 390243104481401 & DENMAS 10 & $12 / 1 / 2005$ & -0.02 & -0.8 & -1.9 & \\
\hline
\end{tabular}


Table 11. Summary of carbon-14 age-tracer data and modeled age adjustments for groundwater samples, Denver Basin aquifer system, Colorado, 2003-5.-Continued

[USGS, U.S. Geological Survey; ${ }^{3} \mathrm{H}$, tritium; TU, tritium units; ${ }^{14} \mathrm{C}$, carbon-14; pmC, percent modern carbon; $8{ }^{13} \mathrm{C}$, delta carbon- 13 ; $\mathrm{CO}_{2}$, carbon dioxide; $\mathrm{BP}$, before present; $\mathrm{Mg}$, magnesium; $\mathrm{Na}$, sodium; mmol/ $\mathrm{kg}$, millimoles per kilogram; <, less than; >, greater than; na, not applicable or no Netpath model; --, no phase transfer in modeled solution; $\mathrm{A}_{0}$, initial ${ }^{14} \mathrm{C}$ activity (pmC) of groundwater when recharged; well name in bold used as initial well; $\mathrm{Ca}$, calcium.

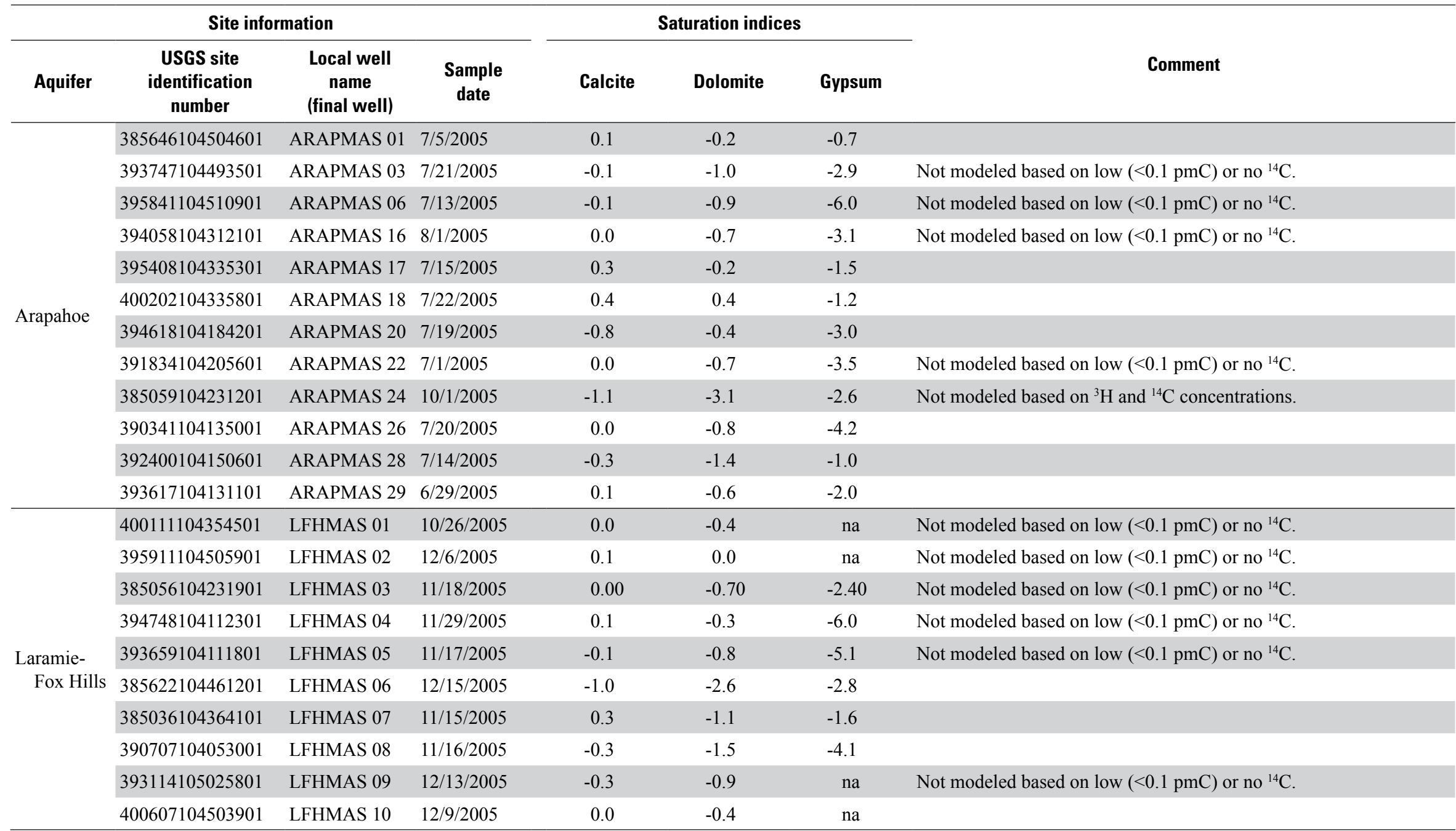

\footnotetext{
${ }^{1}$ Denormalized values for ${ }^{14} \mathrm{C}$. Unadjusted ages shown were calculated by using the ${ }^{14} \mathrm{C}$ Libby half-life of 5,568 years and an initial carbon activity of 100 pmC as described by Plummer and others (2004)

${ }^{2}$ Adjusted ages calculated by using NetpathXL (Plummer and others, 1994; Parkhurst and Charlton, 2008).

${ }^{3}$ Ages rounded to thousands.

${ }^{4}$ Using $\mathrm{A}_{0}$ value of initial well.

${ }^{5}$ Positive for dissolution; negative for precipitation.

${ }^{6} \mathrm{Ca} / \mathrm{Na}$ exchange; may include $\mathrm{Mg} / \mathrm{Na}$ exchange if not separately noted.
} 
Table 12. Model constraints, model phases, and isotopic data used in Netpath models for groundwater samples, Denver Basin aquifer system, Colorado, 2003-5.

$\left[\delta^{13} \mathrm{C}\right.$, delta carbon-13; \%o, per mil; VPDB, Vienna Peedee Belemnite; ${ }^{14} \mathrm{C}$, carbon-14; pmC, percent modern carbon; na, not applicable; redox, oxidationreduction condition]

\begin{tabular}{|c|c|c|c|}
\hline $\begin{array}{c}\text { Model } \\
\text { constraints }\end{array}$ & $\begin{array}{l}\text { Model (mineral } \\
\text { or gas) phase }\end{array}$ & $\begin{array}{c}\delta^{13} \mathbf{C}, \\
\text { model } \\
\text { phase, } \%, \\
\text { VPDB }^{1}\end{array}$ & $\begin{array}{c}{ }^{14} \mathrm{C} \text {, model } \\
\text { phase } \\
\text { (pmC) }\end{array}$ \\
\hline \multirow{9}{*}{$\begin{array}{l}\text { Calcium, carbon, } \\
\text { magnesium, } \\
\text { sodium, sulfur, } \\
\text { redox, silica }\end{array}$} & Calcite & -3 to +4 & 0 \\
\hline & Dolomite & -3 to +3 & 0 \\
\hline & Lignite & -28 to -16 & 0 \\
\hline & Carbon dioxide & -25 to -19 & 100 \\
\hline & Silica & na & na \\
\hline & Gypsum & na & na \\
\hline & Pyrite & na & na \\
\hline & $\begin{array}{l}\text { Calcium/sodium } \\
\text { exchange }\end{array}$ & na & na \\
\hline & $\begin{array}{l}\text { Magnesium/sodium } \\
\text { exchange }\end{array}$ & na & na \\
\hline
\end{tabular}

${ }^{1}$ Range is for modeled values used in NetpathXL modeling (Parkhurst and Charlton, 2008; Plummer and others, 1994) (described in table 11), which are within range of representative values for selected mineral or gas phases (for example, Scoffin, 1987; Kyser, 1987).

Multiple inverse models were generated with NetpathXL, from which a single model was selected as the best possible representation of geochemical reactions that accounted for the measured composition of each sample. As discussed by Plummer and others (1994), the mass-balance reactions determined by the models should be considered non-unique because small variations in model parameters might provide similar matches between measured and calculated values. Such variations in model parameters, however, generally did not result in substantially different results for modeled ${ }^{14} \mathrm{C}$ ages. Models were evaluated in part on the basis of mineral saturation indices (SI) and how closely the modeled $\delta^{13} \mathrm{C}$ value matched the measured $\delta^{13} \mathrm{C}$ value (table 11); minerals that dissolved and precipitated to achieve mass balance were evaluated for consistency with SI values and thermodynamic analysis. Dolomite, gypsum, and lignite were constrained in the models to only dissolve and not precipitate. Most bedrockaquifer samples had higher SI values for calcite, dolomite, and gypsum than did the initial well (DAWMAS 12), indicating that these minerals (model phases) were unlikely to precipitate (table 11). The median $\delta^{13} \mathrm{C}$ value for samples from the Dawson aquifer (-13.41 per mil) was relatively light, whereas median values for the Denver, Arapahoe, and Laramie-Fox Hills aquifers generally were heavier and similar to each other (table 5). For the Dawson aquifer, samples with the lightest $\delta^{13} \mathrm{C}$ values (that is, < about -14 per mil) were mostly from wells near recharge areas such as the Palmer Divide and the western basin margin, indicating that the heavier values associated with the deeper bedrock aquifers likely result from geochemical reactions. The heaviest $\delta^{13} \mathrm{C}$ values (that is, $>$ about -8 per mil), which occurred in samples from the Arapahoe and Laramie-Fox Hills aquifers, generally were associated with wells located along the eastern and northern parts of the basin, likely reflecting longer regional flow paths and older groundwater. High alkalinity values can be indicative of redox and carbonate mineral reactions, which can affect the interpretation of ${ }^{14} \mathrm{C}$ ages. Alkalinity generally increased from the Dawson to Denver to Arapahoe to Laramie-Fox Hills aquifers (table 5). Relatively low alkalinity values for the Dawson aquifer generally corresponded with calcite undersaturation; several of the deeper Arapahoe aquifer samples were undersaturated with respect to calcite, but most Denver, Arapahoe, and Laramie-Fox Hills samples were close to calcite saturation (table 11). The DO concentration for many of the samples from the bedrock aquifers, particularly those from the deeper aquifers, was lower than that for the initial well; the dissolution of organic matter was often required to account for this change in redox state and to reduce the DO concentration. Models that included the dissolution of calcite, dolomite, gypsum, or lignite were generally considered more plausible and were selected over models that included the precipitation of calcite. For some models, recrystallization of calcite (isotopic exchange) was included as a mechanism to increase the modeled $\delta^{13} \mathrm{C}$ value when realistic mass-balance reactions alone resulted in modeled $\delta^{13} \mathrm{C}$ values that were too low relative to measured values. Carbonate minerals are present in the bedrock aquifers (Robson and Banta, 1993; Raynolds and others, 2001), although based on bedrock aquifer mineralogy, calcite recrystallization is not likely to be a dominant geochemical process; as a result, the modeled proportions of isotopic exchange included were relatively minor ( $\leq 0.6$ millimoles per kilogram) (table 11). Gypsum has been detected in the bedrock aquifers (Raynolds and others, 2001; Amber Brenzikofer, Colorado Mineral Society, written commun., 2013) (fig. 33) and in surface efflorescence deposits in the basin (Herring and Walton-Day, 2007). Lignite is present in the bedrock aquifers, including in extensive beds (Soister 1978a, 1978b; Robson and Banta, 1993; Raynolds and others, 2001) (table 1). Silicate reactions such as the dissolution of albite and precipitation of kaolinite were considered on the basis of the lithology of the bedrock aquifers for a number of samples but did not result in models with notable differences in adjusted ages; as a result, the simpler models (not including albite and kaolinite reactions) are described in this report (table 11). Similarly, for samples with high $\mathrm{Fe}$ concentrations, additional models were considered that included reactions with Fe, siderite, and goethite. Siderite has been detected in aquifer sediments (Robson and Banta, 1993; Raynolds and others, 2001). These models did not have 
$\boldsymbol{A}$

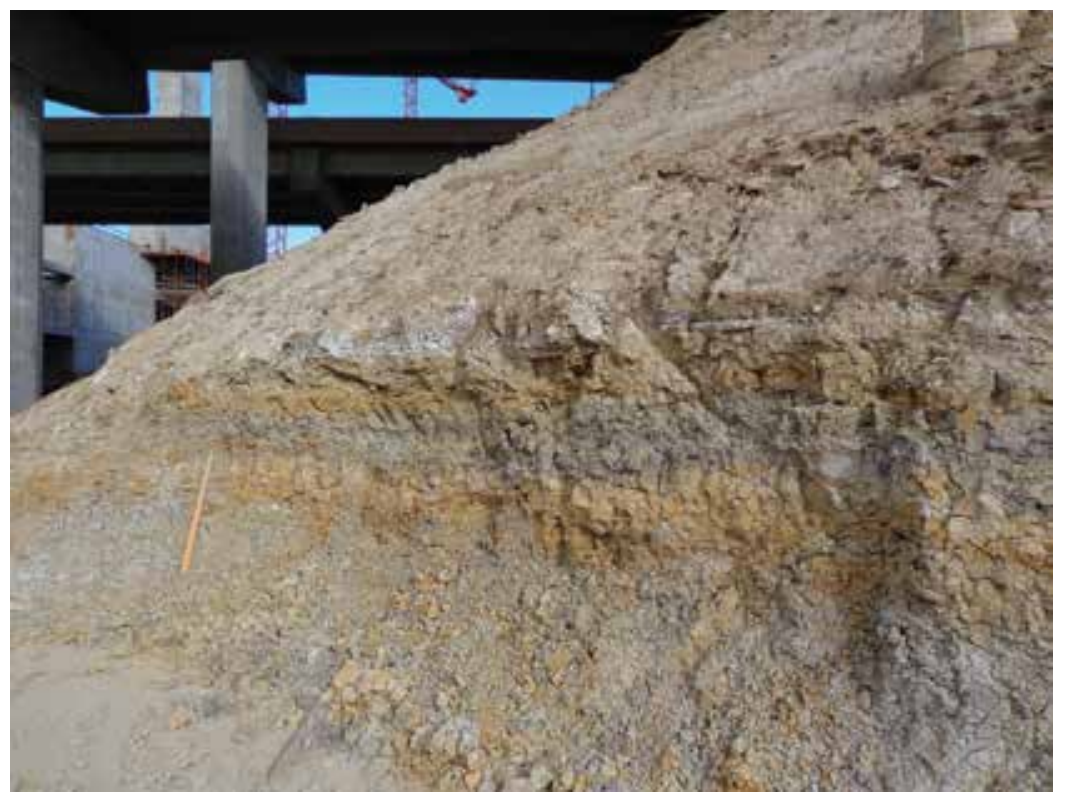

\section{B}

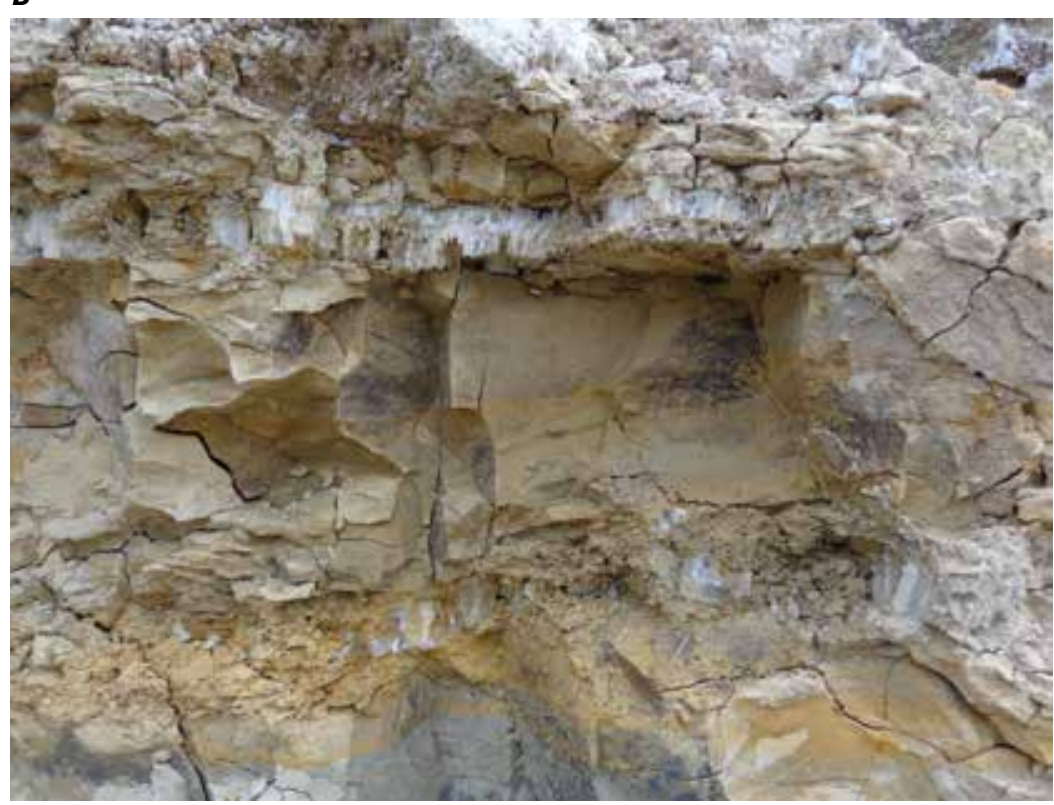

Figure 33. Occurrence of gypsum in Denver Formation sediments, Adams County, Colorado (photographs courtesy of Amber Brenzikofer, Colorado Mineral Society). $A$, Layers of gypsum in Denver Formation sediments exposed by construction activities. $B$, Inset of gypsum layers showing 2- to 3-inch layers interbedded with claystone, siltstone, and fine-grained sandstone.

notable differences in adjusted ages and, as a result, are not described in this report. In general, the modeled geochemical reactions tend to increase the ${ }^{14} \mathrm{C}$ activity of DIC, resulting in younger ages when they are accounted for in the model age adjustments (table 11). Adjusted model ages were rounded to the nearest thousand years. For modeling of the sample used as the initial well (DAWMAS 12), different age-model options within NetpathXL resulted in an adjusted ${ }^{14} \mathrm{C}$ age that ranged from modern to 1,000-year-old groundwater. On the basis of the nondetection of ${ }^{3} \mathrm{H}$ and low $\mathrm{CFC}$ concentrations, the sample from well DAWMAS 12 was categorized as mixed (table 13). 
Table 13. Summary of age tracers, age interpretation, and associated data for groundwater samples, Denver Basin aquifer system, Colorado, 2003-5.

[Values shown with a strikethrough were determined to be unsuitable for groundwater age interpretation. USGS, U.S. Geological Survey; ft, feet; $\delta \mathrm{D}$, delta deuterium; $\delta^{18} \mathrm{O}$, delta oxygen-18; $\delta^{13} \mathrm{C}$, delta carbon-13; per mil, parts per thousand; CFC, chlorofluorocarbon; pptv, parts per trillion by volume; ${ }^{3} \mathrm{H}$, tritium; TU, tritium units; mg/L, milligrams per liter; ${ }^{14} \mathrm{C}$, carbon-14; pmC, percent modern carbon; --, not measured; na, not applicable; M, presence verified but not quantified; <, less than; >, greater than; $\sim$, about;

$\%$, percent; DO, dissolved oxygen; $\geq$, greater than or equal to; selected (best-fit) age model in bold]

\begin{tabular}{|c|c|c|c|c|c|c|c|c|c|c|c|c|c|}
\hline \multicolumn{5}{|c|}{ Site information } & \multicolumn{3}{|c|}{ Stable isotopes } & \multicolumn{6}{|c|}{ CFC age models ${ }^{1}$} \\
\hline Aquifer & $\begin{array}{c}\text { USGS site } \\
\text { identification } \\
\text { number }\end{array}$ & $\begin{array}{l}\text { Local well } \\
\text { name } \\
\text { (final wells) }\end{array}$ & $\begin{array}{c}\text { Sample } \\
\text { date }\end{array}$ & $\begin{array}{c}\text { Well } \\
\text { depth } \\
\text { (ft below } \\
\text { land } \\
\text { surface) }\end{array}$ & $\begin{array}{c}\delta D \\
\text { (per mil) }\end{array}$ & $\begin{array}{c}\delta^{18} 0 \\
\text { (per mil) }\end{array}$ & $\begin{array}{c}\delta^{13} \mathrm{C} \\
\text { (per mil) }\end{array}$ & $\begin{array}{l}\text { Piston- } \\
\text { flow } \\
\text { model } \\
\text { apparent } \\
\text { age } \\
\text { (years) }\end{array}$ & $\begin{array}{c}\text { Dispersion } \\
\text { model } \\
\text { mean age } \\
\text { (years } \\
\text { dispersion } \\
\text { parameter) }\end{array}$ & $\begin{array}{l}\text { Basis for } \\
\text { dispersion } \\
\text { model }\end{array}$ & $\begin{array}{c}\text { Binary- } \\
\text { mixing } \\
\text { model, age } \\
\text { of young } \\
\text { fraction } \\
\text { (years) }\end{array}$ & $\begin{array}{c}\text { Fraction } \\
\text { young } \\
\text { water in } \\
\text { binary } \\
\text { mixture } \\
(\%)\end{array}$ & $\begin{array}{l}\text { Basis for } \\
\text { binary } \\
\text { mixing } \\
\text { model }\end{array}$ \\
\hline \multirow{15}{*}{$\begin{array}{l}\text { Water- } \\
\text { table } \\
\text { wells }\end{array}$} & 394310104393401 & AGLUS 1 & $7 / 29 / 2003$ & 20.0 & -104 & -14.05 & -- & 33 & na & na & 16 & 32 & $\begin{array}{l}\text { CFC-12 \& } \\
\text { CFC-113 }\end{array}$ \\
\hline & 395909104350401 & AGLUS 6 & $7 / 28 / 2003$ & 42.4 & -106 & -13.57 & -- & 28 & na & na & 19 & 64 & $\begin{array}{l}\text { CFC-12 \& } \\
\text { CFC-113 }\end{array}$ \\
\hline & 395541104385701 & AGLUS 7 & $7 / 28 / 2003$ & 18.7 & -98.5 & -12.52 & -- & 21 & na & na & 15 & 78 & $\begin{array}{l}\text { CFC-12 \& } \\
\text { CFC-113 }\end{array}$ \\
\hline & 394539104305901 & AGLUS 12 & $8 / 4 / 2003$ & 44.4 & -102 & -13.24 & -- & 19 & na & na & 3 & 53 & CFC-113 \\
\hline & 394947104335201 & AGLUS 14 & $7 / 31 / 2003$ & 33.4 & -126 & -16.79 & -- & 16 & na & na & 14 & 85 & $\begin{array}{l}\text { CFC-12 \& } \\
\text { CFC-113 }\end{array}$ \\
\hline & 395352104302801 & AGLUS 18 & $7 / 31 / 2003$ & 46.2 & -114 & -14.79 & -- & 24 & na & na & na & na & na \\
\hline & 394919104291001 & AGLUS 20 & $8 / 4 / 2003$ & 29.1 & -104 & -13.89 & -- & 15 & na & na & na & na & na \\
\hline & 394351104302901 & AGLUS REF2 & $7 / 30 / 2003$ & 46.1 & -97.9 & -13.12 & -- & 27 & na & na & na & na & na \\
\hline & 393458104544101 & URLUS 6 & $11 / 20 / 2003$ & 28.6 & -- & -- & -- & 14 & na & na & na & na & na \\
\hline & 393408104544001 & URLUS 7 & $11 / 20 / 2003$ & 49.6 & -109 & -14.20 & -- & 24 & na & na & na & na & na \\
\hline & 393846104465501 & URLUS 18 & $12 / 8 / 2003$ & 38.7 & -99.2 & -12.89 & -- & 15 & na & na & na & na & na \\
\hline & 393655104463001 & URLUS 21 & $12 / 1 / 2003$ & 48.9 & -- & -- & -- & 25 & na & na & na & na & na \\
\hline & 393654104472001 & URLUS 22 & $12 / 1 / 2003$ & 18.9 & -- & -- & -- & 15 & na & na & na & na & na \\
\hline & 393057104441101 & URLUS 24 & $11 / 25 / 2003$ & 24.9 & -- & -- & -- & 31 & na & na & na & na & na \\
\hline & 393700104454101 & URLUS 26 & $12 / 2 / 2003$ & 42.3 & -- & -- & -- & Modern & na & na & na & na & na \\
\hline \multirow{12}{*}{ Dawson } & 393226104490101 & DAWMAS 07 & $12 / 10 / 2004$ & 340 & -104 & -13.69 & -13.41 & 17 & $19(0.34)$ & $\begin{array}{l}{ }^{3} \mathrm{H} \mathrm{\&} \\
\quad \mathrm{CFC}-113\end{array}$ & na & na & na \\
\hline & 393125104433701 & DAWMAS 08 & $12 / 3 / 2004$ & 480 & -106 & -14.07 & -- & 49 & na & na & 25 & 6 & ${ }^{3} \mathrm{H} \& \mathrm{CFC}-12$ \\
\hline & 392339104482601 & DAWMAS 09 & $12 / 7 / 2004$ & 790 & -107 & -14.24 & -14.19 & 48 & na & na & 27 & 5 & $\begin{array}{l}\text { CFC-11 \& } \\
\text { CFC-113 }\end{array}$ \\
\hline & 391605104475001 & DAWMAS 10 & $1 / 20 / 2005$ & 224 & -114 & -15.18 & -12.88 & 33 & na & na & 25 & 56 & ${ }^{3} \mathrm{H} \& \mathrm{CFC}-12$ \\
\hline & 390716104470801 & DAWMAS 11 & $12 / 2 / 2004$ & 380 & -113 & -14.95 & -- & 53 & na & na & na & na & na \\
\hline & 390342104464401 & DAWMAS 12 & $12 / 9 / 2004$ & 360 & -113 & -15.10 & -18.95 & 50 & na & na & 11 & 3.4 & ${ }^{3} \mathrm{H} \& \mathrm{CFC}-12$ \\
\hline & 385758104414801 & DAWMAS 13 & $12 / 13 / 2005$ & 280 & -78.8 & -10.30 & -15.65 & 47 & na & na & 28 & 11 & ${ }^{3} \mathrm{H} \& \mathrm{CFC}-12$ \\
\hline & 390717104400401 & DAWMAS 14 & $11 / 30 / 2004$ & 350 & -103 & -13.64 & -14.18 & 56 & na & na & na & na & na \\
\hline & 391606104392701 & DAWMAS 15 & $12 / 1 / 2004$ & 315 & -109 & -14.43 & -- & 48 & na & na & 17 & 5 & ${ }^{3} \mathrm{H} \& \mathrm{CFC}-12$ \\
\hline & 392727104385201 & DAWMAS 17 & $12 / 28 / 2004$ & 295 & -110 & -14.30 & -10.37 & 38 & na & na & 30 & 45 & ${ }^{3} \mathrm{H} \& \mathrm{CFC}-12$ \\
\hline & 391148104294101 & DAWMAS 27 & $12 / 8 / 2004$ & 475 & -105 & -13.97 & -12.52 & 40 & na & na & 23 & 19 & ${ }^{3} \mathrm{H} \& \mathrm{CFC}-12$ \\
\hline & 391848104261401 & DAWMAS 28 & $12 / 14 / 2004$ & 388 & -111 & -14.62 & -9.66 & 34 & na & na & 16 & 17 & ${ }^{3} \mathrm{H} \& \mathrm{CFC}-12$ \\
\hline
\end{tabular}


Table 13. Summary of age tracers, age interpretation, and associated data for groundwater samples, Denver Basin aquifer system, Colorado, 2003-5.-Continued

[Values shown with a strikethrough were determined to be unsuitable for groundwater age interpretation. USGS, U.S. Geological Survey; ft, feet; $\delta \mathrm{D}$, delta deuterium; $\delta^{18} \mathrm{O}$, delta oxygen-18; $\delta^{13} \mathrm{C}$, delta carbon-13; per mil, parts per thousand; CFC, chlorofluorocarbon; pptv, parts per trillion by volume; ${ }^{3} \mathrm{H}$, tritium; TU, tritium units; mg/L, milligrams per liter; ${ }^{14} \mathrm{C}$, carbon-14; pmC, percent modern carbon; --, not measured; na, not applicable; M, presence verified but not quantified; <, less than; >, greater than; $\sim$, about;

$\%$, percent; DO, dissolved oxygen; $\geq$, greater than or equal to; selected (best-fit) age model in bold]

\begin{tabular}{|c|c|c|c|c|c|c|c|c|c|c|c|c|c|}
\hline \multicolumn{5}{|c|}{ Site information } & \multicolumn{3}{|c|}{ Stable isotopes } & \multicolumn{6}{|c|}{ CFC age models ${ }^{1}$} \\
\hline Aquifer & $\begin{array}{c}\text { USGS site } \\
\text { identification } \\
\text { number }\end{array}$ & $\begin{array}{l}\text { Local well } \\
\text { name } \\
\text { (final wells) }\end{array}$ & $\begin{array}{l}\text { Sample } \\
\text { date }\end{array}$ & $\begin{array}{c}\text { Well } \\
\text { depth } \\
\text { (ft below } \\
\text { land } \\
\text { surface) }\end{array}$ & $\begin{array}{c}\text { סD } \\
\text { (per mil) }\end{array}$ & $\begin{array}{c}\delta^{18} 0 \\
\text { (per mil) }\end{array}$ & $\begin{array}{c}\delta^{13} \mathrm{C} \\
\text { (per mil) }\end{array}$ & $\begin{array}{l}\text { Piston- } \\
\text { flow } \\
\text { model } \\
\text { apparent } \\
\text { age } \\
\text { (years) }\end{array}$ & $\begin{array}{l}\text { Dispersion } \\
\text { model } \\
\text { mean age } \\
\text { (years } \\
\text { dispersion } \\
\text { parameter) }\end{array}$ & $\begin{array}{l}\text { Basis for } \\
\text { dispersion } \\
\text { model }\end{array}$ & $\begin{array}{c}\text { Binary- } \\
\text { mixing } \\
\text { model, age } \\
\text { of young } \\
\text { fraction } \\
\text { (years) }\end{array}$ & $\begin{array}{c}\text { Fraction } \\
\text { young } \\
\text { water in } \\
\text { binary } \\
\text { mixture } \\
(\%)\end{array}$ & $\begin{array}{l}\text { Basis for } \\
\text { binary } \\
\text { mixing } \\
\text { model }\end{array}$ \\
\hline \multirow{10}{*}{ Denver } & 392559104415201 & DENMAS 01 & $8 / 25 / 2005$ & 940 & -105 & -14.04 & -11.73 & -- & -- & -- & -- & -- & -- \\
\hline & 394134104305701 & DENMAS 02 & $9 / 8 / 2005$ & 663 & -99.7 & -13.42 & -10.60 & -- & -- & -- & -- & -- & -- \\
\hline & 390226104134801 & DENMAS 03 & $9 / 13 / 2005$ & 679 & -92.5 & -12.46 & -5.92 & -- & -- & -- & -- & -- & -- \\
\hline & 385816104411201 & DENMAS 04 & $10 / 1 / 2005$ & 460 & -83.7 & -11.04 & -13.07 & 58 & na & na & 35 & 3 & ${ }^{3} \mathrm{H} \& \mathrm{CFC}-12$ \\
\hline & 391851104204501 & DENMAS 05 & $12 / 29 / 2005$ & 545 & -- & -- & -9.10 & 61 & na & na & na & na & na \\
\hline & 391825104272101 & DENMAS 06 & 9/28/2005 & 963 & -- & -- & -- & -- & -- & -- & -- & -- & -- \\
\hline & 390534104465501 & DENMAS 07 & $10 / 25 / 2005$ & 1,150 & -106 & -14.27 & -10.27 & -- & -- & -- & -- & -- & -- \\
\hline & 393227104493001 & DENMAS 08 & $10 / 13 / 2005$ & 441 & -109 & -14.38 & -- & 36 & na & na & 22.6 & 36 & ${ }^{3} \mathrm{H} \& \mathrm{CFC}-12$ \\
\hline & 393304104444201 & DENMAS 09 & $10 / 25 / 2005$ & 675 & -107 & -14.03 & -12.17 & -- & -- & -- & -- & -- & -- \\
\hline & 390243104481401 & DENMAS 10 & $12 / 1 / 2005$ & 500 & -92.6 & -12.47 & -11.15 & 57 & na & na & na & na & na \\
\hline \multirow{12}{*}{ Arapahoe } & 385646104504601 & ARAPMAS 01 & $7 / 5 / 2005$ & 280 & -75.1 & -10.79 & -10.60 & -- & -- & -- & -- & -- & -- \\
\hline & 393747104493501 & ARAPMAS 03 & $7 / 21 / 2005$ & 1,225 & -104 & -14.48 & -12.78 & -- & -- & -- & -- & -- & -- \\
\hline & 395841104510901 & ARAPMAS 06 & $7 / 13 / 2005$ & 440 & -103 & -13.99 & -8.02 & -- & -- & -- & -- & -- & -- \\
\hline & 394058104312101 & ARAPMAS 16 & $8 / 1 / 2005$ & 892 & -100 & -13.39 & -10.14 & -- & -- & -- & -- & -- & -- \\
\hline & 395408104335301 & ARAPMAS 17 & $7 / 15 / 2005$ & 440 & -109 & -14.35 & -13.82 & 54 & na & na & na & na & na \\
\hline & 400202104335801 & ARAPMAS 18 & $7 / 22 / 2005$ & 520 & -110 & -15.06 & -11.51 & -- & -- & -- & -- & -- & -- \\
\hline & 394618104184201 & ARAPMAS 20 & $7 / 19 / 2005$ & 367 & -93.4 & -13.02 & -7.59 & 51 & na & na & na & na & na \\
\hline & 391834104205601 & ARAPMAS 22 & $7 / 1 / 2005$ & 832 & -94.0 & -12.68 & -7.68 & 56 & na & na & na & na & na \\
\hline & 385059104231201 & ARAPMAS 24 & $10 / 1 / 2005$ & 380 & -76.9 & -10.19 & -7.43 & 12 & 23 & $\begin{array}{l}{ }^{3} \mathrm{H} \& \\
\quad \text { CFC-12 }\end{array}$ & na & na & na \\
\hline & 390341104135001 & ARAPMAS 26 & $7 / 20 / 2005$ & 550.00 & -85.4 & -12.10 & -5.29 & 55 & na & na & na & na & na \\
\hline & 392400104150601 & ARAPMAS 28 & $7 / 14 / 2005$ & 434 & -106 & -13.92 & -10.68 & -- & -- & -- & -- & -- & -- \\
\hline & 393617104131101 & ARAPMAS 29 & $6 / 29 / 2005$ & 420 & -107 & -14.36 & -11.69 & -- & -- & -- & -- & -- & -- \\
\hline \multirow{10}{*}{$\begin{array}{l}\text { Laramie- } \\
\text { Fox } \\
\text { Hills }\end{array}$} & 400111104354501 & LFHMAS 01 & $10 / 26 / 2005$ & 1,020 & -97.1 & -13.01 & -4.42 & -- & -- & -- & -- & -- & -- \\
\hline & 395911104505901 & LFHMAS 02 & $12 / 6 / 2005$ & 1,000 & -102 & -13.33 & -12.08 & -- & -- & -- & -- & -- & -- \\
\hline & 385056104231901 & LFHMAS 03 & $11 / 18 / 2005$ & 880 & -71.3 & -9.99 & -16.05 & -- & -- & -- & -- & -- & -- \\
\hline & 394748104112301 & LFHMAS 04 & $11 / 29 / 2005$ & 515 & -84.7 & -11.59 & -8.51 & 56 & na & na & na & na & na \\
\hline & 393659104111801 & LFHMAS 05 & $11 / 17 / 2005$ & 800 & -95.2 & -12.89 & -7.95 & 55 & na & na & na & na & na \\
\hline & 385622104461201 & LFHMAS 06 & $12 / 15 / 2005$ & 1,450 & -85.0 & -12.13 & -12.99 & -- & -- & -- & -- & -- & -- \\
\hline & 385036104364101 & LFHMAS 07 & $11 / 15 / 2005$ & 835 & -72.2 & -9.61 & -13.71 & -- & -- & -- & -- & -- & -- \\
\hline & 390707104053001 & LFHMAS 08 & $11 / 16 / 2005$ & 683 & -84.8 & -11.72 & -9.14 & -- & -- & -- & -- & -- & -- \\
\hline & 393114105025801 & LFHMAS 09 & $12 / 13 / 2005$ & 1,145 & -114 & -14.95 & -19.06 & -- & -- & -- & -- & -- & -- \\
\hline & 400607104503901 & LFHMAS 10 & $12 / 9 / 2005$ & 590 & -102 & -13.59 & -9.38 & 41 & na & na & na & na & na \\
\hline
\end{tabular}


Table 13. Summary of age tracers, age interpretation, and associated data for groundwater samples, Denver Basin aquifer system, Colorado, 2003-5.-Continued

[Values shown with a strikethrough were determined to be unsuitable for groundwater age interpretation. USGS, U.S. Geological Survey; ft, feet; $\delta \mathrm{D}$, delta deuterium; $\delta^{18} \mathrm{O}$, delta oxygen-18; $\delta^{13} \mathrm{C}$, delta carbon-13; per mil, parts per thousand; CFC, chlorofluorocarbon; pptv, parts per trillion by volume; ${ }^{3} \mathrm{H}$, tritium; TU, tritium units; mg/L, milligrams per liter; ${ }^{14} \mathrm{C}$, carbon-14; pmC, percent modern carbon; --, not measured; na, not applicable; M, presence verified but not quantified; <, less than; >, greater than; , about; \%, percent; DO, dissolved oxygen; $\geq$, greater than or equal to; selected (best-fit) age model in bold]

\begin{tabular}{|c|c|c|c|c|c|c|c|c|c|}
\hline \multicolumn{4}{|c|}{ Site information } & \multicolumn{2}{|c|}{ Tritium } & \multirow[b]{2}{*}{$\begin{array}{l}\text { Dissolved } \\
\text { oxygen } \\
\text { (mg/L) }\end{array}$} & \multicolumn{3}{|c|}{${ }^{14} \mathrm{C}$ age models ${ }^{2}$} \\
\hline Aquifer & $\begin{array}{c}\text { USGS site } \\
\text { identification number }\end{array}$ & $\begin{array}{l}\text { Local well name } \\
\text { (final wells) }\end{array}$ & $\begin{array}{c}\text { Sample } \\
\text { date }\end{array}$ & $\begin{array}{c}{ }^{3} \mathrm{H} \\
\text { (TU) }\end{array}$ & $\begin{array}{c}{ }^{3} \mathrm{H} \text { uncertainty, } \\
\text { 2-sigma } \\
\text { (TU) }\end{array}$ & & $\begin{array}{l}{ }^{14} \mathrm{C} \\
(\mathrm{pmC})\end{array}$ & $\begin{array}{l}\text { Unadjusted } \\
{ }^{14} \mathrm{C} \text { age } \\
\text { (years) }\end{array}$ & $\begin{array}{c}\text { Adjusted } \\
{ }^{14} \mathrm{C} \text { age } \\
\text { (years) Netpath }\end{array}$ \\
\hline \multirow{15}{*}{$\begin{array}{l}\text { Water- } \\
\text { table } \\
\text { wells }\end{array}$} & 394310104393401 & AGLUS 1 & $7 / 29 / 2003$ & -- & -- & 2.4 & -- & -- & -- \\
\hline & 395909104350401 & AGLUS 6 & $7 / 28 / 2003$ & -- & -- & 6.6 & -- & -- & -- \\
\hline & 395541104385701 & AGLUS 7 & $7 / 28 / 2003$ & -- & -- & 4.3 & -- & -- & -- \\
\hline & 394539104305901 & AGLUS 12 & $8 / 4 / 2003$ & -- & -- & 2.8 & -- & -- & -- \\
\hline & 394947104335201 & AGLUS 14 & $7 / 31 / 2003$ & -- & -- & 8.6 & -- & -- & -- \\
\hline & 395352104302801 & AGLUS 18 & $7 / 31 / 2003$ & -- & -- & 9.2 & -- & -- & -- \\
\hline & 394919104291001 & AGLUS 20 & $8 / 4 / 2003$ & -- & -- & 11.5 & -- & -- & -- \\
\hline & 394351104302901 & AGLUS REF2 & $7 / 30 / 2003$ & -- & -- & 0.5 & -- & -- & -- \\
\hline & 393458104544101 & URLUS 6 & $11 / 20 / 2003$ & -- & -- & 0.2 & -- & -- & -- \\
\hline & 393408104544001 & URLUS 7 & $11 / 20 / 2003$ & -- & -- & 0.8 & -- & -- & -- \\
\hline & 393846104465501 & URLUS 18 & $12 / 8 / 2003$ & -- & -- & 0.8 & -- & -- & -- \\
\hline & 393655104463001 & URLUS 21 & $12 / 1 / 2003$ & -- & -- & 0.3 & -- & -- & -- \\
\hline & 393654104472001 & URLUS 22 & $12 / 1 / 2003$ & -- & -- & 0.5 & -- & -- & -- \\
\hline & 393057104441101 & URLUS 24 & $11 / 25 / 2003$ & -- & -- & 0.3 & -- & -- & -- \\
\hline & 393700104454101 & URLUS 26 & $12 / 2 / 2003$ & -- & -- & 7.5 & -- & -- & -- \\
\hline \multirow{12}{*}{ Dawson } & 393226104490101 & DAWMAS 07 & $12 / 10 / 2004$ & 13.4 & 0.8 & 4.5 & 104 & 0 & na \\
\hline & 393125104433701 & DAWMAS 08 & $12 / 3 / 2004$ & 0.4 & 0.2 & 1.7 & -- & -- & -- \\
\hline & 392339104482601 & DAWMAS 09 & $12 / 7 / 2004$ & $<0.2$ & 0.2 & 3.7 & 10.2 & 18,000 & 14,000 \\
\hline & 391605104475001 & DAWMAS 10 & $1 / 20 / 2005$ & 3.8 & 0.5 & 7.9 & 84.3 & 1,000 & na \\
\hline & 390716104470801 & DAWMAS 11 & $12 / 2 / 2004$ & $<0.2$ & 0.2 & 3.9 & -- & -- & -- \\
\hline & 390342104464401 & DAWMAS 12 & $12 / 9 / 2004$ & $<0.2$ & 0.2 & 5.6 & 85.5 & 1,000 & 0 to 1,000 \\
\hline & 385758104414801 & DAWMAS 13 & $12 / 13 / 2005$ & 1.0 & 0.3 & 0.1 & 34.1 & 9,000 & na \\
\hline & 390717104400401 & DAWMAS 14 & $11 / 30 / 2004$ & 0.1 & 0.2 & 2.1 & 16.0 & 15,000 & 9,000 \\
\hline & 391606104392701 & DAWMAS 15 & $12 / 1 / 2004$ & $<0.2$ & 0.2 & 4.8 & -- & -- & -- \\
\hline & 392727104385201 & DAWMAS 17 & $12 / 28 / 2004$ & 7.5 & 0.5 & 8.8 & 88.7 & 1,000 & na \\
\hline & 391148104294101 & DAWMAS 27 & $12 / 8 / 2004$ & 1.7 & 0.2 & 9.4 & 75.2 & 2,000 & na \\
\hline & 391848104261401 & DAWMAS 28 & $12 / 14 / 2004$ & 0.6 & 0.3 & 4.8 & 81.9 & 2,000 & na \\
\hline
\end{tabular}


Table 13. Summary of age tracers, age interpretation, and associated data for groundwater samples, Denver Basin aquifer system, Colorado, 2003-5.-Continued

[Values shown with a strikethrough were determined to be unsuitable for groundwater age interpretation. USGS, U.S. Geological Survey; ft, feet; $\delta \mathrm{D}$, delta deuterium; $\delta^{18} \mathrm{O}$, delta oxygen-18; $\delta^{13} \mathrm{C}$, delta carbon-13; per mil, parts per thousand; CFC, chlorofluorocarbon; pptv, parts per trillion by volume; ${ }^{3} \mathrm{H}$, tritium; TU, tritium units; mg/L, milligrams per liter; ${ }^{14} \mathrm{C}$, carbon-14; pmC, percent modern carbon; --, not measured; na, not applicable; M, presence verified but not quantified; <, less than; >, greater than; $\sim$, about; \%, percent; DO, dissolved oxygen; $\geq$, greater than or equal to; selected (best-fit) age model in bold]

\begin{tabular}{|c|c|c|c|c|c|c|c|c|c|}
\hline \multicolumn{4}{|c|}{ Site information } & \multicolumn{2}{|c|}{ Tritium } & \multirow[b]{2}{*}{$\begin{array}{c}\text { Dissolved } \\
\text { oxygen } \\
\text { (mg/L) }\end{array}$} & \multicolumn{3}{|c|}{${ }^{14} \mathrm{C}$ age models ${ }^{2}$} \\
\hline Aquifer & $\begin{array}{c}\text { USGS site } \\
\text { identification number }\end{array}$ & $\begin{array}{l}\text { Local well name } \\
\text { (final wells) }\end{array}$ & $\begin{array}{l}\text { Sample } \\
\text { date }\end{array}$ & $\begin{array}{c}{ }^{3} \mathrm{H} \\
\text { (TU) }\end{array}$ & $\begin{array}{c}{ }^{3} \mathrm{H} \text { uncertainty, } \\
\text { 2-sigma } \\
\text { (TU) }\end{array}$ & & $\begin{array}{c}{ }^{14} \mathrm{C} \\
(\mathrm{pmC})\end{array}$ & $\begin{array}{c}\text { Unadjusted } \\
{ }^{14} \mathrm{C} \text { age } \\
\text { (years) }\end{array}$ & $\begin{array}{c}\text { Adjusted } \\
{ }^{14} \mathrm{C} \text { age } \\
\text { (years) Netpath }\end{array}$ \\
\hline \multirow{10}{*}{ Denver } & 392559104415201 & DENMAS 01 & $8 / 25 / 2005$ & $<0.2$ & 0.2 & 0.2 & 0.0 & $>30,000$ & na \\
\hline & 394134104305701 & DENMAS 02 & $9 / 8 / 2005$ & $<0.3$ & 0.3 & 0.3 & 0.4 & 44,000 & $>\mathbf{3 0 , 0 0 0}$ \\
\hline & 390226104134801 & DENMAS 03 & $9 / 13 / 2005$ & $<0.3$ & 0.3 & 1.0 & 13.9 & 16,000 & 8,000 \\
\hline & 385816104411201 & DENMAS 04 & $10 / 1 / 2005$ & 0.5 & 0.3 & 0.1 & 16.3 & 15,000 & na \\
\hline & 391851104204501 & DENMAS 05 & $12 / 29 / 2005$ & $<0.1$ & 0.2 & 0.0 & 0.0 & $>30,000$ & na \\
\hline & 391825104272101 & DENMAS 06 & $9 / 28 / 2005$ & $<0.1$ & 0.3 & 0.5 & -- & -- & 24,000 \\
\hline & 390534104465501 & DENMAS 07 & $10 / 25 / 2005$ & $<0.2$ & 0.2 & 0.1 & 2.5 & 30,000 & -- \\
\hline & 393227104493001 & DENMAS 08 & $10 / 13 / 2005$ & 2.2 & 0.3 & 0.2 & -- & -- & -- \\
\hline & 393304104444201 & DENMAS 09 & $10 / 25 / 2005$ & $<0.2$ & 0.2 & 0.3 & 0.8 & 39,000 & $>\mathbf{3 0 , 0 0 0}$ \\
\hline & 390243104481401 & DENMAS 10 & $12 / 1 / 2005$ & $<0.2$ & 0.2 & 0.6 & 11.5 & 17,000 & 12,000 \\
\hline \multirow{12}{*}{ Arapahoe } & 385646104504601 & ARAPMAS 01 & $7 / 5 / 2005$ & $<0.2$ & 0.2 & 0.1 & 14.6 & 15,000 & 9,000 \\
\hline & 393747104493501 & ARAPMAS 03 & $7 / 21 / 2005$ & $<0.1$ & 0.2 & 3.4 & 0.0 & $>\mathbf{3 0 , 0 0 0}$ & na \\
\hline & 395841104510901 & ARAPMAS 06 & $7 / 13 / 2005$ & $<0.2$ & 0.2 & 0.1 & 0.0 & $>\mathbf{3 0 , 0 0 0}$ & na \\
\hline & 394058104312101 & ARAPMAS 16 & $8 / 1 / 2005$ & $<0.2$ & 0.2 & 0.1 & 0.0 & $>30,000$ & na \\
\hline & 395408104335301 & ARAPMAS 17 & $7 / 15 / 2005$ & $<0.2$ & 0.2 & 0.1 & 0.6 & $>30,000$ & 28,000 \\
\hline & 400202104335801 & ARAPMAS 18 & $7 / 22 / 2005$ & $<0.2$ & 0.2 & 0.7 & 11.6 & 17,000 & 12,000 \\
\hline & 394618104184201 & ARAPMAS 20 & $7 / 19 / 2005$ & $<0.2$ & 0.2 & M & 11.1 & 18,000 & 10,000 \\
\hline & 391834104205601 & ARAPMAS 22 & $7 / 1 / 2005$ & 0.1 & 0.2 & 0.1 & 0.0 & $>30,000$ & na \\
\hline & 385059104231201 & ARAPMAS 24 & $10 / 1 / 2005$ & 11.2 & 0.8 & 6.3 & 106 & 0 & na \\
\hline & 390341104135001 & ARAPMAS 26 & $7 / 20 / 2005$ & $<0.2$ & 0.2 & 0.3 & 5.2 & 24,000 & 16,000 \\
\hline & 392400104150601 & ARAPMAS 28 & $7 / 14 / 2005$ & $<0.2$ & 0.2 & 0.1 & 2.5 & 30,000 & 25,000 \\
\hline & 393617104131101 & ARAPMAS 29 & $6 / 29 / 2005$ & $<0.2$ & 0.2 & 0.1 & 2.6 & 29,000 & 24,000 \\
\hline \multirow{10}{*}{$\begin{array}{l}\text { Laramie- } \\
\text { Fox } \\
\text { Hills }\end{array}$} & 400111104354501 & LFHMAS 01 & $10 / 26 / 2005$ & $<0.3$ & 0.3 & 0.2 & 0.0 & $>\mathbf{3 0 , 0 0 0}$ & na \\
\hline & 395911104505901 & LFHMAS 02 & $12 / 6 / 2005$ & $<0.2$ & 0.2 & 1.3 & 0.0 & $>\mathbf{3 0 , 0 0 0}$ & na \\
\hline & 385056104231901 & LFHMAS 03 & $11 / 18 / 2005$ & $<0.2$ & 0.3 & 0.1 & 0.0 & $>30,000$ & na \\
\hline & 394748104112301 & LFHMAS 04 & $11 / 29 / 2005$ & $<0.2$ & 0.2 & 0.1 & 0.0 & $>\mathbf{3 0 , 0 0 0}$ & na \\
\hline & 393659104111801 & LFHMAS 05 & $11 / 17 / 2005$ & $<0.2$ & 0.2 & 0.0 & 0.0 & $>30,000$ & na \\
\hline & 385622104461201 & LFHMAS 06 & $12 / 15 / 2005$ & $<0.2$ & 0.2 & 0.1 & 1.2 & $>30,000$ & $>30,000$ \\
\hline & 385036104364101 & LFHMAS 07 & $11 / 15 / 2005$ & $<0.3$ & 0.3 & $\mathrm{M}$ & 4.8 & 24,000 & 18,000 \\
\hline & 390707104053001 & LFHMAS 08 & $11 / 16 / 2005$ & $<0.2$ & 0.2 & $\mathrm{M}$ & 10.9 & 18,000 & 12,000 \\
\hline & 393114105025801 & LFHMAS 09 & $12 / 13 / 2005$ & $<0.2$ & 0.2 & 0.1 & 0.0 & $>30,000$ & na \\
\hline & 400607104503901 & LFHMAS 10 & $12 / 9 / 2005$ & $<0.2$ & 0.2 & 0.0 & 0.1 & $>30,000$ & $>\mathbf{3 0 , 0 0 0}$ \\
\hline
\end{tabular}


Table 13. Summary of age tracers, age interpretation, and associated data for groundwater samples, Denver Basin aquifer system, Colorado, 2003-5.-Continued

[Values shown with a strikethrough were determined to be unsuitable for groundwater age interpretation. USGS, U.S. Geological Survey; ft, feet; $\delta \mathrm{D}$, delta deuterium; $\delta^{18} \mathrm{O}$, delta oxygen-18; $\delta^{13} \mathrm{C}$, delta carbon-13; per mil, parts per thousand; CFC, chlorofluorocarbon; pptv, parts per trillion by volume; ${ }^{3} \mathrm{H}$, tritium; TU, tritium units; mg/L, milligrams per liter; ${ }^{14} \mathrm{C}$, carbon-14; pmC, percent modern carbon; --, not measured; na, not applicable; M, presence verified but not quantified; <, less than; >, greater than; , about; \%, percent; DO, dissolved oxygen; $\geq$, greater than or equal to; selected (best-fit) age model in bold]

\begin{tabular}{|c|c|c|c|c|c|}
\hline \multicolumn{4}{|c|}{ Site information } & \multirow{2}{*}{$\begin{array}{l}\text { General } \\
\text { age } \\
\text { cat- } \\
\text { egory }\end{array}$} & \multirow[b]{2}{*}{ Comment } \\
\hline Aquifer & $\begin{array}{l}\text { USGS site } \\
\text { identification } \\
\text { number }\end{array}$ & $\begin{array}{c}\text { Local well } \\
\text { name } \\
\text { (final wells) }\end{array}$ & $\begin{array}{c}\text { Sample } \\
\text { date }\end{array}$ & & \\
\hline \multirow{15}{*}{$\begin{array}{l}\text { Water- } \\
\text { table } \\
\text { wells }\end{array}$} & 394310104393401 & AGLUS 1 & $7 / 29 / 2003$ & Mixed & CFC results consistent with mixture of young and old (CFC-free) water. \\
\hline & 395909104350401 & AGLUS 6 & $7 / 28 / 2003$ & Mixed & $\mathrm{CFC}$ results consistent with mixture of young and old (CFC-free) water. \\
\hline & 395541104385701 & AGLUS 7 & $7 / 28 / 2003$ & Mixed & $\mathrm{CFC}$ results consistent with mixture of young and old (CFC-free) water. \\
\hline & 394539104305901 & AGLUS 12 & $8 / 4 / 2003$ & Mixed & $\mathrm{CFC}$ results consistent with mixture of young and old (CFC-free) water. \\
\hline & 394947104335201 & AGLUS 14 & $7 / 31 / 2003$ & Mixed & $\mathrm{CFC}$ results consistent with mixture of young and old (CFC-free) water. \\
\hline & 395352104302801 & AGLUS 18 & $7 / 31 / 2003$ & Young & \\
\hline & 394919104291001 & AGLUS 20 & $8 / 4 / 2003$ & Young & \\
\hline & 394351104302901 & AGLUS REF2 & $7 / 30 / 2003$ & Young & \\
\hline & 393458104544101 & URLUS 6 & $11 / 20 / 2003$ & Young & \\
\hline & 393408104544001 & URLUS 7 & $11 / 20 / 2003$ & Young & \\
\hline & 393846104465501 & URLUS 18 & $12 / 8 / 2003$ & Young & \\
\hline & 393655104463001 & URLUS 21 & $12 / 1 / 2003$ & Young & \\
\hline & 393654104472001 & URLUS 22 & $12 / 1 / 2003$ & Young & \\
\hline & 393057104441101 & URLUS 24 & $11 / 25 / 2003$ & Young & Age determination suspect because of possible CFC degradation; likely younger than 31 years. \\
\hline & 393700104454101 & URLUS 26 & $12 / 2 / 2003$ & Young & Age determination not possible due to CFC contamination; likely modern. \\
\hline \multirow{12}{*}{ Dawson } & 393226104490101 & DAWMAS 07 & $12 / 10 / 2004$ & Young & Concentration of ${ }^{14} \mathrm{C},{ }^{3} \mathrm{H}$, and CFCs consistent with young water. \\
\hline & 393125104433701 & DAWMAS 08 & $12 / 3 / 2004$ & Mixed & $\begin{array}{l}\text { Detected, low }{ }^{3} \mathrm{H} \text { concentration consistent with recharge in late } 1950 \text { s as determined by CFCs; CFC results } \\
\text { consistent with mixture of young and old (CFC-free) water. }\end{array}$ \\
\hline & 392339104482601 & DAWMAS 09 & $12 / 7 / 2004$ & Mixed & $\begin{array}{l}\text { Nondetection of }{ }^{3} \mathrm{H},{ }^{14} \mathrm{C} \text { concentration, and corrected }{ }^{14} \mathrm{C} \text { age consistent with old water. } \mathrm{CFC} \text { results consistent } \\
\text { with a minor component of young water. }\end{array}$ \\
\hline & 391605104475001 & DAWMAS 10 & $1 / 20 / 2005$ & Mixed & $\begin{array}{l}\text { Mixed age based on unadjusted }{ }^{14} \mathrm{C} \text { age of } \geq 1,000 \text { years, with detected }{ }^{3} \mathrm{H} \text { concentration. } \mathrm{CFC} \text { age interpretation } \\
\text { consistent with mixed water. }\end{array}$ \\
\hline & 390716104470801 & DAWMAS 11 & $12 / 2 / 2004$ & Old & $\begin{array}{l}\text { Nondetection of }{ }^{3} \mathrm{H} \text { consistent with old water (CFC age interpretation suspect due to possible low-level CFC } \\
\text { contamination). }\end{array}$ \\
\hline & 390342104464401 & DAWMAS 12 & $12 / 9 / 2004$ & Mixed & $\begin{array}{l}\text { Classified as mixed age due to uncertainties. Nondetection of }{ }^{3} \mathrm{H} \text { consistent with old water. Used as initial well } \\
\text { for }{ }^{14} \mathrm{C} \text { age modeling and adjusted age varies depending on age model. CFC results consistent with mixture } \\
\text { of young and old (CFC-free) water. }\end{array}$ \\
\hline & 385758104414801 & DAWMAS 13 & $12 / 13 / 2005$ & Mixed & $\begin{array}{l}\text { Mixed age based on unadjusted }{ }^{14} \mathrm{C} \text { age of } \geq 1,000 \text { years, with detected (low) }{ }^{3} \mathrm{H} \text { concentration. } \mathrm{CFC} \text { results } \\
\text { consistent with mixed-age interpretation, although also suspect based on low } \mathrm{DO} \text { and possible degradation. }\end{array}$ \\
\hline & 390717104400401 & DAWMAS 14 & $11 / 30 / 2004$ & Old & $\begin{array}{l}\text { Concentration of }{ }^{3} \mathrm{H} \text { and }{ }^{14} \mathrm{C} \text { and corrected }{ }^{14} \mathrm{C} \text { age consistent with old water (CFC results suspect due to pos- } \\
\text { sible low-level CFC contamination). }\end{array}$ \\
\hline & 391606104392701 & DAWMAS 15 & $12 / 1 / 2004$ & Mixed & Nondetection of ${ }^{3} \mathrm{H}$ consistent with old water; CFC results consistent with mixed-age interpretation. \\
\hline & 392727104385201 & DAWMAS 17 & $12 / 28 / 2004$ & Mixed & $\begin{array}{l}\text { Mixed age based on unadjusted }{ }^{14} \mathrm{C} \text { age of } \geq 1,000 \text { years, with detected }{ }^{3} \mathrm{H} \text { concentration. } \mathrm{CFC} \text { results consistent } \\
\text { with mixed-age interpretation. }\end{array}$ \\
\hline & 391148104294101 & DAWMAS 27 & $12 / 8 / 2004$ & Mixed & $\begin{array}{l}\text { Mixed age based on unadjusted }{ }^{14} \mathrm{C} \text { age of } \geq 1,000 \text { years, with detected }{ }^{3} \mathrm{H} \text { concentration. } \mathrm{CFC} \text { results consistent } \\
\text { with mixed water. }\end{array}$ \\
\hline & 391848104261401 & DAWMAS 28 & $12 / 14 / 2004$ & Mixed & $\begin{array}{l}\text { Mixed age based on unadjusted }{ }^{14} \mathrm{C} \text { age of } \geq 1,000 \text { years, with detected }{ }^{3} \mathrm{H} \text { concentration. } \mathrm{CFC} \text { results consistent } \\
\text { with mixed water. }\end{array}$ \\
\hline
\end{tabular}


Table 13. Summary of age tracers, age interpretation, and associated data for groundwater samples, Denver Basin aquifer system, Colorado, 2003-5.-Continued

[Values shown with a strikethrough were determined to be unsuitable for groundwater age interpretation. USGS, U.S. Geological Survey; ft, feet; $\delta \mathrm{D}$, delta deuterium; $\delta^{18} \mathrm{O}$, delta oxygen-18; $\delta^{13} \mathrm{C}$, delta carbon-13; per mil, parts per thousand; CFC, chlorofluorocarbon; pptv, parts per trillion by volume; ${ }^{3} \mathrm{H}$, tritium; TU, tritium units; mg/L, milligrams per liter; ${ }^{14} \mathrm{C}$, carbon-14; pmC, percent modern carbon; --, not measured; na, not applicable; M, presence verified but not quantified; <, less than; >, greater than; $\sim$, about; \%, percent; DO, dissolved oxygen; $\geq$, greater than or equal to; selected (best-fit) age model in bold $]$

\begin{tabular}{|c|c|c|c|c|c|}
\hline \multicolumn{4}{|c|}{ Site information } & \multirow{2}{*}{$\begin{array}{l}\text { General } \\
\text { age } \\
\text { cat- } \\
\text { egory }\end{array}$} & \multirow[b]{2}{*}{ Comment } \\
\hline Aquifer & $\begin{array}{c}\text { USGS site } \\
\text { identification } \\
\text { number }\end{array}$ & $\begin{array}{c}\text { Local well } \\
\text { name } \\
\text { (final wells) }\end{array}$ & $\begin{array}{c}\text { Sample } \\
\text { date }\end{array}$ & & \\
\hline \multirow{10}{*}{ Denver } & 392559104415201 & DENMAS 01 & $8 / 25 / 2005$ & Old & Nondetection of ${ }^{3} \mathrm{H}$ and ${ }^{14} \mathrm{C}$ consistent with old water. \\
\hline & 394134104305701 & DENMAS 02 & $9 / 8 / 2005$ & Old & Nondetection of ${ }^{3} \mathrm{H},{ }^{14} \mathrm{C}$ concentration, and corrected ${ }^{14} \mathrm{C}$ age consistent with old water. \\
\hline & 390226104134801 & DENMAS 03 & $9 / 13 / 2005$ & Old & Nondetection of ${ }^{3} \mathrm{H},{ }^{14} \mathrm{C}$ concentration, and corrected ${ }^{14} \mathrm{C}$ age consistent with old water. \\
\hline & 385816104411201 & DENMAS 04 & $10 / 1 / 2005$ & Mixed & $\begin{array}{l}\text { Mixed age based on unadjusted }{ }^{14} \mathrm{C} \text { age of } \geq 1,000 \text { years, with detected }{ }^{3} \mathrm{H} \text { concentration (CFC age interpretation } \\
\text { suspect). }\end{array}$ \\
\hline & 391851104204501 & DENMAS 05 & $12 / 29 / 2005$ & Old & $\begin{array}{l}\text { Nondetection of }{ }^{3} \mathrm{H} \text { and }{ }^{14} \mathrm{C} \text { consistent with old water (CFC age interpretation suspect due to possible low-level } \\
\text { CFC contamination). }\end{array}$ \\
\hline & 391825104272101 & DENMAS 06 & $9 / 28 / 2005$ & Old & Nondetection of ${ }^{3} \mathrm{H}$ consistent with old water. \\
\hline & 390534104465501 & DENMAS 07 & $10 / 25 / 2005$ & Old & Nondetection of ${ }^{3} \mathrm{H},{ }^{14} \mathrm{C}$ concentration, and corrected ${ }^{14} \mathrm{C}$ age consistent with old water. \\
\hline & 393227104493001 & DENMAS 08 & $10 / 13 / 2005$ & Mixed & $\begin{array}{l}\text { Detection of }{ }^{3} \mathrm{H} \text { and } \mathrm{CFC} \text { concentrations consistent with young water. Binary mixing model consistent with } \\
\text { mixed water (CFC age intepretation suspect based on low DO and possible degradation). }\end{array}$ \\
\hline & 393304104444201 & DENMAS 09 & $10 / 25 / 2005$ & Old & Nondetection of ${ }^{3} \mathrm{H},{ }^{14} \mathrm{C}$ concentration, and corrected ${ }^{14} \mathrm{C}$ age consistent with old water. \\
\hline & 390243104481401 & DENMAS 10 & $12 / 1 / 2005$ & Old & $\begin{array}{l}\text { Nondetection of }{ }^{3} \mathrm{H},{ }^{14} \mathrm{C} \text { concentration, and corrected }{ }^{14} \mathrm{C} \text { age consistent with old water (CFC age interpretation } \\
\text { suspect). }\end{array}$ \\
\hline \multirow{12}{*}{ Arapahoe } & 385646104504601 & ARAPMAS 01 & $7 / 5 / 2005$ & Old & Nondetection of ${ }^{3} \mathrm{H},{ }^{14} \mathrm{C}$ concentration, and corrected ${ }^{14} \mathrm{C}$ age consistent with old water. \\
\hline & 393747104493501 & ARAPMAS 03 & $7 / 21 / 2005$ & Old & Nondetection of ${ }^{3} \mathrm{H}$ and ${ }^{14} \mathrm{C}$ consistent with old water. \\
\hline & 395841104510901 & ARAPMAS 06 & $7 / 13 / 2005$ & Old & Nondetection of ${ }^{3} \mathrm{H}$ and ${ }^{14} \mathrm{C}$ consistent with old water. \\
\hline & 394058104312101 & ARAPMAS 16 & $8 / 1 / 2005$ & Old & Nondetection of ${ }^{3} \mathrm{H}$ and ${ }^{14} \mathrm{C}$ consistent with old water. \\
\hline & 395408104335301 & ARAPMAS 17 & $7 / 15 / 2005$ & Old & $\begin{array}{l}\text { Nondetection of }{ }^{3} \mathrm{H},{ }^{14} \mathrm{C} \text { concentration, and corrected }{ }^{14} \mathrm{C} \text { age consistent with old water (CFC age interpretation } \\
\text { suspect). }\end{array}$ \\
\hline & 400202104335801 & ARAPMAS 18 & $7 / 22 / 2005$ & Old & Nondetection of ${ }^{3} \mathrm{H},{ }^{14} \mathrm{C}$ concentration, and corrected ${ }^{14} \mathrm{C}$ age consistent with old water. \\
\hline & 394618104184201 & ARAPMAS 20 & $7 / 19 / 2005$ & Old & $\begin{array}{l}\text { Nondetection of }{ }^{3} \mathrm{H},{ }^{14} \mathrm{C} \text { concentration, and corrected }{ }^{14} \mathrm{C} \text { age consistent with old water (CFC age interpretation } \\
\text { suspect). }\end{array}$ \\
\hline & 391834104205601 & ARAPMAS 22 & $7 / 1 / 2005$ & Old & Low concentration of ${ }^{3} \mathrm{H}$ and ${ }^{14} \mathrm{C}$ consistent with old water (CFC age interpretation suspect). \\
\hline & 385059104231201 & ARAPMAS 24 & $10 / 1 / 2005$ & Young & Concentration of ${ }^{14} \mathrm{C},{ }^{3} \mathrm{H}$, and $\mathrm{CFC}$ age tracers consistent with young water. \\
\hline & 390341104135001 & ARAPMAS 26 & $7 / 20 / 2005$ & Old & $\begin{array}{l}\text { Nondetection of }{ }^{3} \mathrm{H},{ }^{14} \mathrm{C} \text { concentration, and corrected }{ }^{14} \mathrm{C} \text { age consistent with old water (CFC age interpretation } \\
\text { suspect due to possible low-level CFC contamination). }\end{array}$ \\
\hline & 392400104150601 & ARAPMAS 28 & $7 / 14 / 2005$ & Old & Nondetection of ${ }^{3} \mathrm{H},{ }^{14} \mathrm{C}$ concentration, and corrected ${ }^{14} \mathrm{C}$ age consistent with old water. \\
\hline & 393617104131101 & ARAPMAS 29 & $6 / 29 / 2005$ & Old & Nondetection of ${ }^{3} \mathrm{H},{ }^{14} \mathrm{C}$ concentration, and corrected ${ }^{14} \mathrm{C}$ age consistent with old water. \\
\hline
\end{tabular}


Table 13. Summary of age tracers, age interpretation, and associated data for groundwater samples, Denver Basin aquifer system, Colorado, 2003-5.-Continued

[Values shown with a strikethrough were determined to be unsuitable for groundwater age interpretation. USGS, U.S. Geological Survey; ft, feet; $\delta \mathrm{D}$, delta deuterium; $\delta^{18} \mathrm{O}$, delta oxygen-18; $\delta^{13} \mathrm{C}$, delta carbon-13; per mil, parts per thousand; $\mathrm{CFC}$, chlorofluorocarbon; pptv, parts per trillion by volume; ${ }^{3} \mathrm{H}$, tritium; TU, tritium units; mg/L, milligrams per liter; ${ }^{14} \mathrm{C}$, carbon-14; pmC, percent modern carbon; --, not measured; na, not applicable; M, presence verified but not quantified; <, less than; >, greater than; , about; \%, percent; DO, dissolved oxygen; $\geq$, greater than or equal to; selected (best-fit) age model in bold]

\begin{tabular}{|c|c|c|c|c|c|}
\hline \multicolumn{4}{|c|}{ Site information } & \multirow{2}{*}{$\begin{array}{c}\text { General } \\
\text { age } \\
\text { cat- } \\
\text { egory }\end{array}$} & \multirow[b]{2}{*}{ Comment } \\
\hline Aquifer & $\begin{array}{c}\text { USGS site } \\
\text { identification } \\
\text { number }\end{array}$ & $\begin{array}{c}\text { Local well } \\
\text { name } \\
\text { (final wells) }\end{array}$ & $\begin{array}{c}\text { Sample } \\
\text { date }\end{array}$ & & \\
\hline \multirow{10}{*}{$\begin{array}{l}\text { Laramie- } \\
\text { Fox } \\
\text { Hills }\end{array}$} & 400111104354501 & LFHMAS 01 & $10 / 26 / 2005$ & Old & Nondetection of ${ }^{3} \mathrm{H}$ and ${ }^{14} \mathrm{C}$ consistent with old water. \\
\hline & 395911104505901 & LFHMAS 02 & $12 / 6 / 2005$ & Old & Nondetection of ${ }^{3} \mathrm{H}$ and ${ }^{14} \mathrm{C}$ consistent with old water. \\
\hline & 385056104231901 & LFHMAS 03 & $11 / 18 / 2005$ & Old & Nondetection of ${ }^{3} \mathrm{H}$ and ${ }^{14} \mathrm{C}$ consistent with old water. \\
\hline & 394748104112301 & LFHMAS 04 & $11 / 29 / 2005$ & Old & $\begin{array}{l}\text { Nondetection of }{ }^{3} \mathrm{H} \text { and }{ }^{14} \mathrm{C} \text { consistent with old water (CFC age interpretation suspect due to possible low-level } \\
\text { CFC contamination). }\end{array}$ \\
\hline & 393659104111801 & LFHMAS 05 & $11 / 17 / 2005$ & Old & $\begin{array}{l}\text { Nondetection of }{ }^{3} \mathrm{H} \text { and }{ }^{14} \mathrm{C} \text { consistent with old water (CFC age interpretation suspect due to possible low-level } \\
\text { CFC contamination). }\end{array}$ \\
\hline & 385622104461201 & LFHMAS 06 & $12 / 15 / 2005$ & Old & Nondetection of ${ }^{3} \mathrm{H},{ }^{14} \mathrm{C}$ concentration, and corrected ${ }^{14} \mathrm{C}$ age consistent with old water. \\
\hline & 385036104364101 & LFHMAS 07 & $11 / 15 / 2005$ & Old & Nondetection of ${ }^{3} \mathrm{H},{ }^{14} \mathrm{C}$ concentration, and corrected ${ }^{14} \mathrm{C}$ age consistent with old water. \\
\hline & 390707104053001 & LFHMAS 08 & $11 / 16 / 2005$ & Old & Nondetection of ${ }^{3} \mathrm{H},{ }^{14} \mathrm{C}$ concentration, and corrected ${ }^{14} \mathrm{C}$ age consistent with old water. \\
\hline & 393114105025801 & LFHMAS 09 & $12 / 13 / 2005$ & Old & Nondetection of ${ }^{3} \mathrm{H}$ and low $(<0.1 \mathrm{pmC}){ }^{14} \mathrm{C}$ concentration consistent with old water. \\
\hline & 400607104503901 & LFHMAS 10 & $12 / 9 / 2005$ & Old & $\begin{array}{l}\text { Nondetection of }{ }^{3} \mathrm{H} \text {, low }(<0.1 \mathrm{pmC}){ }^{14} \mathrm{C} \text {, and corrected }{ }^{14} \mathrm{C} \text { age consistent with old water (CFC age interpreta- } \\
\text { tion suspect due to possible low-level CFC contamination and [or] degradation). }\end{array}$ \\
\hline
\end{tabular}

${ }^{1}$ See table 10 for CFC details.

${ }^{2}$ See table 11 for ${ }^{14} \mathrm{C}$ details.

${ }^{3}$ Adjusted ages calculated by using NetpathXL (Plummer and others, 1994; Parkhurst and Charlton, 2008). 
Adjusted ${ }^{14} \mathrm{C}$ ages for samples from the bedrock aquifers generally increased with well depth (fig. 34). The median adjusted ${ }^{14} \mathrm{C}$ age (hereinafter, ${ }^{14} \mathrm{C}$ age) for samples from the Dawson aquifer was 2,000 years, which was notably younger than that for the other bedrock aquifers, with median ${ }^{14} \mathrm{C}$ ages of 24,000 years for samples from the Arapahoe aquifer and $>30,000$ years for samples from the Denver and Laramie-Fox Hills aquifers. These results are consistent with a previous study that documented old groundwater with residence times from 8,000 to $>30,000$ years in the Denver and Arapahoe aquifers (Novotny and Sanford, 2005).

\section{Interpreted Groundwater Ages}

As described in the "Methods" section, the program TracerLPM (Jurgens and others, 2012) was used to evaluate lumped-parameter models for age interpretation. A variety of models were considered appropriate for samples from the Denver Basin on the basis of aquifer hydrogeology, age-tracer results, tracer-tracer graphs, and age-tracer model results and were used to estimate groundwater age. A piston-flow model was considered for the water-table wells, which were shallow wells with short screened intervals (table 3). For the bedrock aquifers, with potentially longer flow paths and longer screened intervals for wells compared to the watertable wells (table 3), dispersion and mixing are likely to be important processes; as a result, a dispersion model was also considered. For many samples, age-tracer results, tracer-tracer graphs, and model results were consistent with a binarymixing model, which was used to estimate young and old fractions of samples. A binary-mixing model comprising a piston-flow model for the young fraction and a dispersion model for the old fraction was used for all binary-mixing models. The dispersion model used is based on a solution to a one-dimensional advection-dispersion equation as described by Jurgens and others (2012). The model uses a dispersion parameter to define the relative importance of advection to dispersion. For most models used in the current study, the dispersion parameter was set to 0.1 . Lower values of the dispersion parameter $(<0.1)$ simulate behavior of tracer concentrations fairly similar to those of piston flow; higher values $(>0.1)$ simulate more dispersive mixing (Jurgens and others, 2012). A binary-mixing model also was considered for some of the samples from the bedrock aquifers, particularly from the Dawson aquifer, where ${ }^{3} \mathrm{H}$ results indicated that many samples had at least a component of young water.

Based on lumped-parameter model results using TracerLPM (Jurgens and others, 2012) and integrated agetracer results, groundwater samples were grouped into three general age categories: (1) young (post-1950s recharge);

(2) mixed (a binary mixture of young and old water); and (3) old (pre-1950s recharge and, for many samples, ages that are thousands of years old based on ${ }^{14} \mathrm{C}$ ages and a lack of detectable ${ }^{3} \mathrm{H}$ ) (fig. 35; table 13). For some samples,

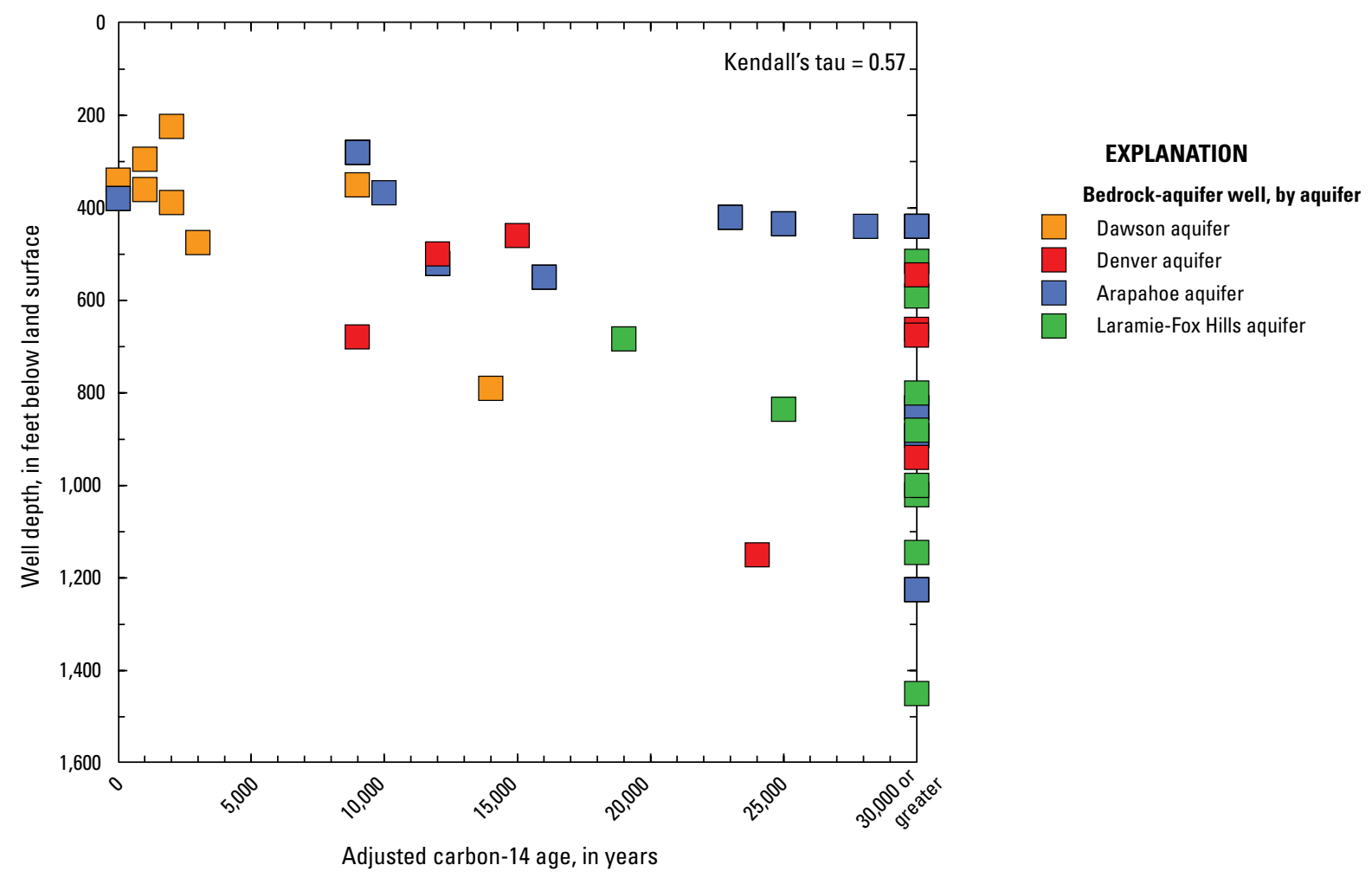

Figure 34. Relation between well depth and adjusted carbon-14 ages for groundwater samples, Denver Basin aquifer system, Colorado, 2003-5. 


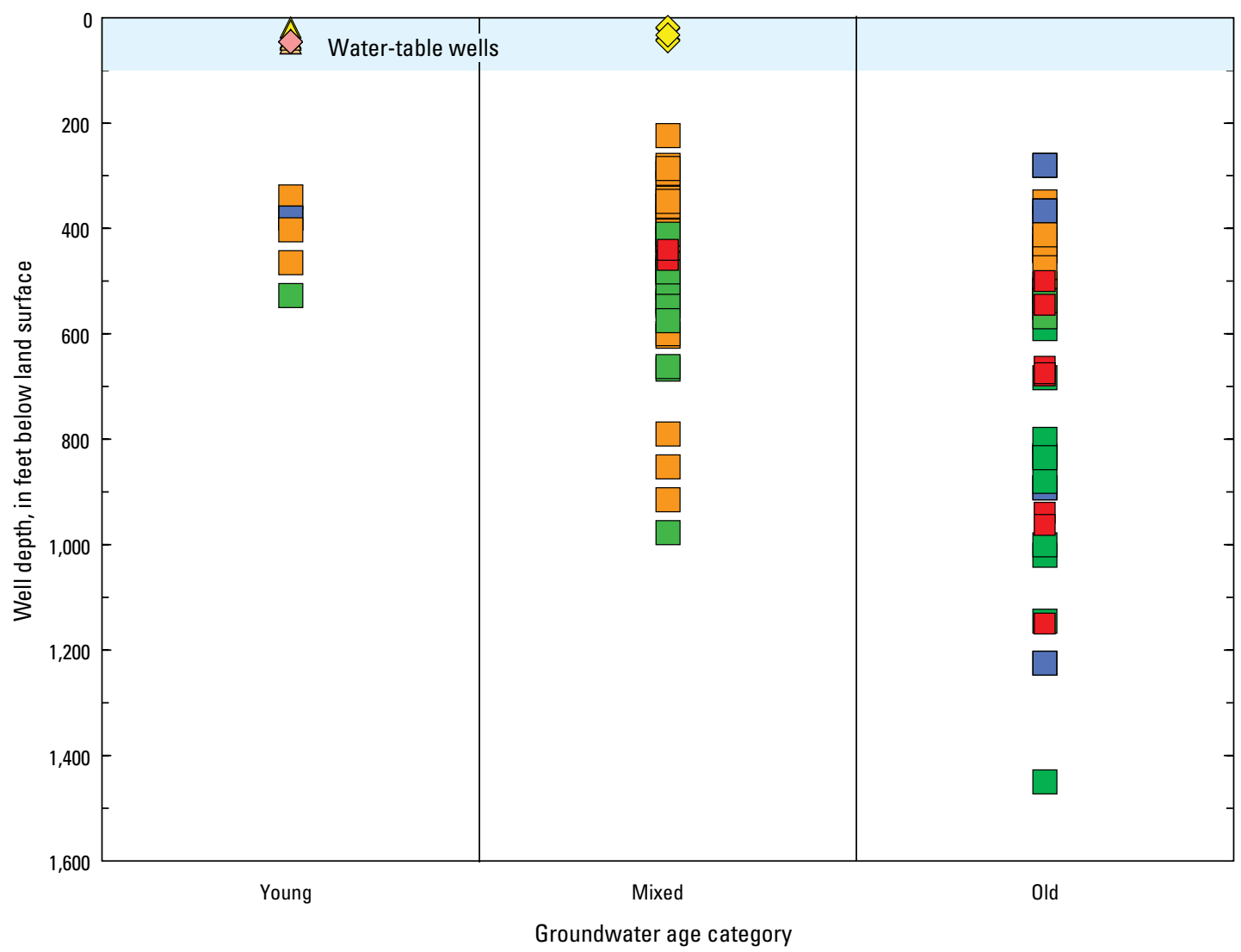

EXPLANATION

Water-table well, by land use

and aquifer

Agricultural land use

$\diamond \quad$ Alluvial aquifer

$\diamond \quad$ Denver aquifer

Urban land use

$\triangle \quad$ Alluvial aquifer

$\triangle \quad$ Dawson aquifer

Bedrock-aquifer well, by aquife

Dawson aquifer

Denver aquifer

Arapahoe aquifer

Laramie-Fox Hills aquifer

Figure 35. Relation between well depth and groundwater age interpretation category for groundwater samples, Denver Basin aquifer system, Colorado, 2003-5.

age categories were based on results for a single age tracer (for example, ${ }^{3} \mathrm{H}$ was the only age tracer collected for some samples from the bedrock aquifers). Low-level CFC contamination was suspected for many of the deeper bedrockaquifer samples from the Denver, Arapahoe, and Laramie-Fox Hills aquifers; as a result, ${ }^{3} \mathrm{H}$ and ${ }^{14} \mathrm{C}$ were the primary tracers used to interpret groundwater ages for samples from these aquifers. Additional age-tracer data might result in refined age estimates. Samples from the water-table wells were categorized as young or mixed; samples from the urban land-use wells were young, whereas most of the agricultural land-use wells were mixed (fig. 35; table 13). For the water-table well samples, there was no relation between well depth and age category. For the bedrock aquifers, 
samples from the Dawson aquifer were mostly categorized as mixed, and samples from the deeper bedrock aquifers were mostly categorized as old (fig. 35). There were several notable exceptions to these generalizations, with 1 sample from the Arapahoe aquifer categorized as young (from well ARAPMAS 24) and 2 samples from the Denver aquifer categorized as mixed (from wells DENMAS 04 and DENMAS 08) (table 13; fig. 35). For mixed-age category samples from the bedrock aquifers, the modeled fraction of young water generally decreased with well depth (young and old age category samples were assumed to have young water fractions of 100 and 0 percent, respectively) (fig. 36).

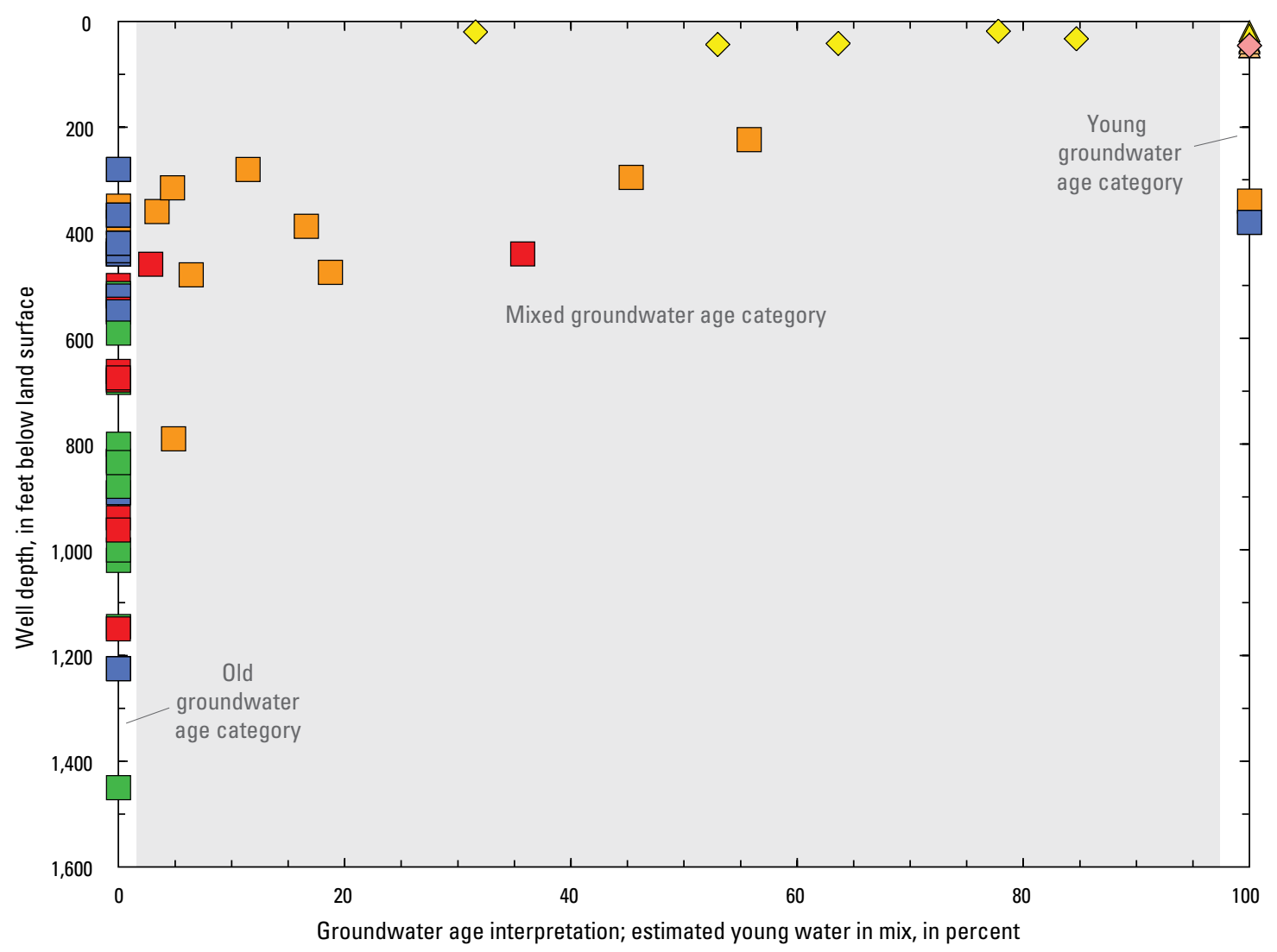

EXPLANATION

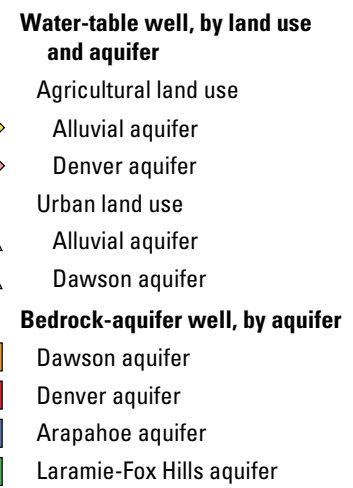

Figure 36. Relation between well depth and the estimated proportion of young water from groundwater age interpretation, Denver Basin aquifer system, Colorado, 2003-5. 


\section{Synthesis: Vulnerability of the Denver Basin Aquifer System to Contamination}

The wide range of constituents analyzed for groundwater samples throughout the Denver Basin provides insight into processes and factors affecting groundwater quality in the region. Additionally, results of the current study provide a framework for evaluating aquifer vulnerability to contaminants derived from geologic sources and human activities. Understanding the vulnerability of Denver Basin groundwater to contamination is important to water-resource managers tasked with maintaining high-quality drinking-water supplies.

Results for groundwater samples from the water-table wells, representative of water quality in the alluvial aquifer and shallowest parts of the bedrock aquifers, indicate that the quality of shallow groundwater is degraded as a result of both natural factors and human activities that have modified the chemistry and hydrology of the Denver Basin. Results of the current study are consistent with previous studies in the region that have described these factors and activities and their effects on water quality (Robson, 1989; Bruce and McMahon, 1998; Paschke and others, 2008; Bails and others, 2009; Paschke, 2011). Agricultural and urban land uses have altered the pattern and composition of recharge in the basin. Increased recharge from irrigation water results in the mobilization of soluble salts and nutrients that have accumulated in the unsaturated zone under natural, semiarid conditions. Leaching of chemicals applied to the land surface, including fertilizers and road salts, contributes to elevated concentrations of dissolved constituents such as $\mathrm{NO}_{3}$ and TDS near the water table (figs. 11 and 19). The development of agricultural and urban land-use areas has increased the vulnerability of Denver Basin groundwater to organic contaminants (figs. 26 and 27). Concentrations of several chemical constituents of concern for human health, including those from both geologic and human sources, are relatively high in shallow groundwater. Water-quality degradation associated with samples from the water-table wells is indicated by relatively high concentrations of TDS, $\mathrm{NO}_{3}$, and selected trace elements (As, U, Se) and relatively frequent detections of pesticides and VOCs (figs. 11 and 37; tables 5 and 9). Around half of the samples from the water-table wells exceeded water-quality SMCL benchmarks for TDS, $\mathrm{SO}_{4}$, and $\mathrm{Mn}$ concentrations (table 5). Additionally, from about 10 to 30 percent of the water-table wells exceeded MCL benchmarks for $\mathrm{NO}_{3}$, U, and Se concentrations (fig. 21; table 5). Water-table wells tended to have a higher frequency of benchmark exceedances than did the bedrock aquifers for most constituents of concern (fig. 21; table 5).

Deep confined groundwater is often considered isolated and resistant to effects from human activities on the land surface (Eberts and others, 2013) and has historically been a high-quality source of drinking water in the Denver Basin. The vulnerability of bedrock aquifer groundwater to contamination can be evaluated by examining selected water-quality properties and concentrations or occurrence of constituents that characterize water quality in the shallow aquifers; these include TDS, $\mathrm{DO}, \mathrm{NO}_{3}, \mathrm{U}, \mathrm{Se}$, and As, as well as pesticides and VOCs that originate solely from human sources. It should be noted that many of the constituents associated with poor or degraded water quality in the shallow aquifer system are affected by redox processes, and generally anoxic conditions in the deeper bedrock aquifers do not favor the transport or persistence of constituents such as $\mathrm{DO}, \mathrm{NO}_{3}$, $\mathrm{U}, \mathrm{Se}, \mathrm{As}$, and some VOCs. Groundwater age tracers provide additional insight into vulnerability of the bedrock aquifers; in conjunction with water-quality data, age-tracer results can help determine if recently recharged groundwater of poor or degraded quality has migrated or has the potential to migrate to deeper parts of the bedrock aquifers used for drinking-water supply.

Relatively high TDS concentrations (exceeding the SMCL of $500 \mathrm{mg} / \mathrm{L}$ ) in some bedrock-aquifer samples likely result from mineral-solution reactions occurring along flow paths over long residence times, such as mineral dissolution and geochemical reactions with clay minerals. The evolution of groundwater chemistry along flow paths for relatively deep, old groundwater is indicated by changes in groundwater composition from shallower, predominantly $\mathrm{Ca}-\mathrm{HCO}_{3}$ waters to $\mathrm{Na}-\mathrm{HCO}_{3}$ or $\mathrm{Na}-\mathrm{SO}_{4}$ waters in deeper bedrock aquifers (fig. 10) and by spatial variability in water quality, such as that for TDS concentrations for the bedrock aquifers (fig. 13).

Concentrations of most constituents associated with poor or degraded water quality in shallow groundwater decreased with depth in the Denver Basin (fig. 37; table 5). Nonetheless, several lines of evidence indicate that young, contaminant-bearing recharge has reached shallow to moderate depths in some parts of the bedrock aquifers (fig. 37). The stratigraphically shallowest bedrock aquifer, the Dawson aquifer, in particular, is vulnerable to contamination from natural and human sources. Most Dawson aquifer samples were characterized by oxic conditions and detections of U, Se, and As (fig. 37). Median concentrations for these constituents were generally intermediate between the watertable wells and the stratigraphically deeper bedrock aquifers (table 5). Additionally, several pesticide compounds were detected in samples from the Dawson aquifer (fig. 37; table 9). Groundwater samples from the Dawson aquifer were interpreted as mostly mixed-age, indicating that young recharge has mixed with old groundwater (table 13). Tritium was detected at concentrations indicative of young groundwater in more than half of Dawson aquifer samples (fig. 37; table 13). Although some Dawson aquifer samples (from wells DAWMAS 11 and DAWMAS 14) were interpreted as many thousands of years old, these samples were also oxic, which independently indicates the likely mixing of old water in the Dawson aquifer with young recharge (table 13). In the stratigraphically deeper bedrock aquifers, constituents of concern for water-quality degradation 


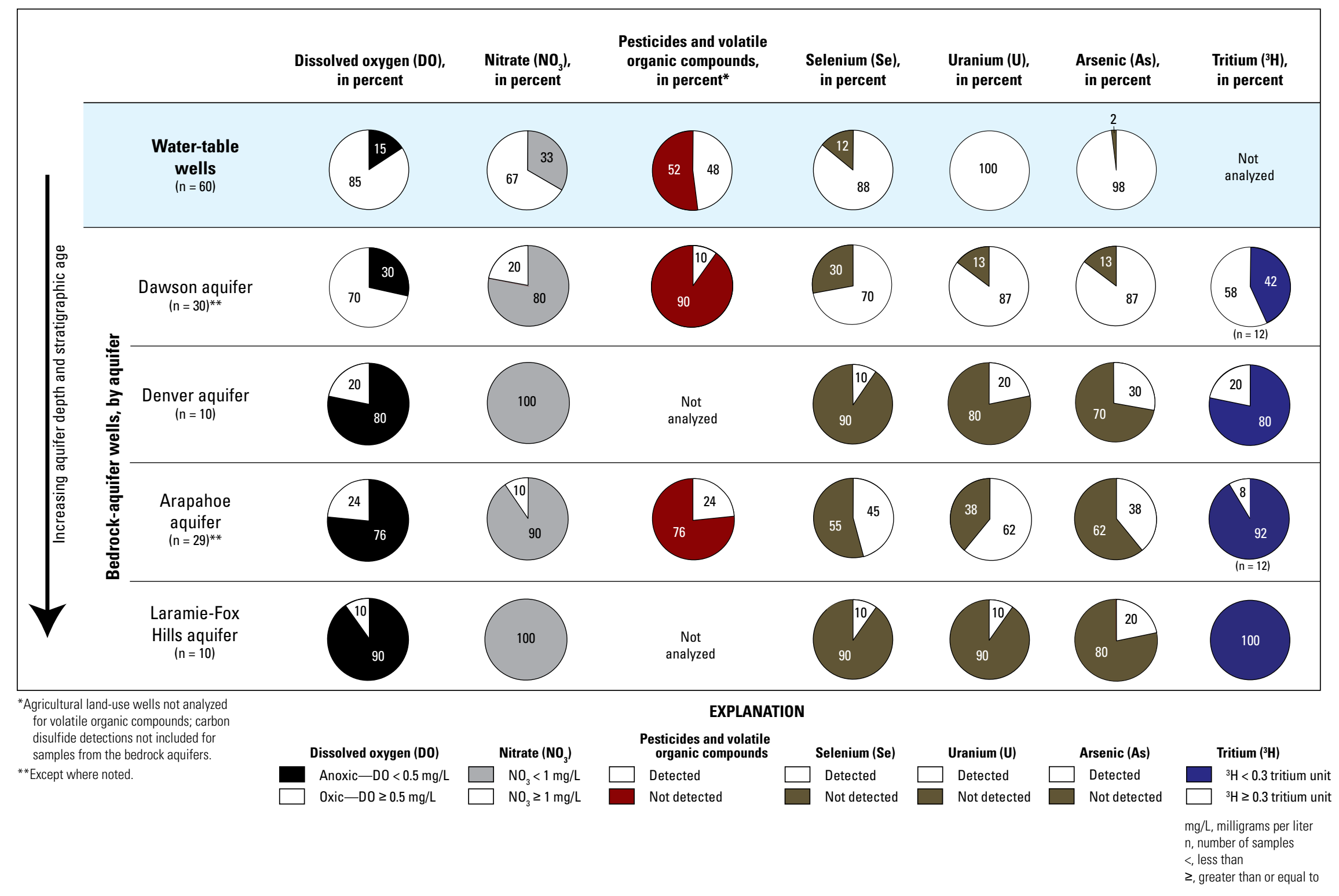

Figure 37. Summary of occurrence and detection of water-quality constituents used to evaluate vulnerability to contamination for groundwater samples, Denver Basin aquifer system, Colorado, 2003-5. 
occurred less frequently and at lower median concentrations (fig. 37; table 5), indicating that these aquifers were less vulnerable to contamination. Age interpretations indicated that groundwater in the Denver, Arapahoe, and Laramie-Fox Hills aquifers is dominantly thousands of years old and has mostly not been affected by mixing with young recharge (table 13); however, most constituents associated with poor or degraded water quality for the shallow aquifer system also occurred in some samples from the deeper bedrock aquifers, including the detection of 11 VOCs in samples from the Arapahoe aquifer (fig. 37; table 9). Additionally, not all groundwater in the deeper bedrock aquifers is old. Some mixtures of young and old groundwater at depth in samples from the Denver aquifer (collected from wells DENMAS 04 and DENMAS 08, with well depths of 460 and $441 \mathrm{ft}$, respectively) and one young groundwater sample from the Arapahoe aquifer (collected from well ARAPMAS 24, with a well depth of $380 \mathrm{ft}$ ) indicate that groundwater mixing with young recharge has occurred locally in the deeper bedrock aquifers. These bedrock-aquifer samples had ${ }^{3} \mathrm{H}$ concentrations that are consistent with mixing with a portion of young groundwater (table 13). Although organic contaminants were not measured for the Denver aquifer samples, three VOCs were detected in the sample collected from well ARAPMAS 24, including the highest chloroform concentration measured in the study $(9.38 \mu \mathrm{g} / \mathrm{L}$; table 9). These results further support the interpretation that young water of poor or degraded quality from the shallow aquifer system has mixed with deeper groundwater in some locations.

Spatial variability in land-surface processes, urban development, and water use might affect the migration of solutes and contaminants from the shallow aquifer system to the bedrock aquifers. Pumping of groundwater from the bedrock aquifers has increased steadily over the last few decades in response to increases in population and publicsupply needs (fig. 7), and flow-modeling results have simulated increases in downward flow through the Denver Basin associated with increased groundwater pumping (Paschke, 2011). As a result, even relatively deep groundwater is susceptible to effects of mixing with poor or degraded quality shallow groundwater in response to pumping-induced gradients.

Although the Arapahoe aquifer is deeper than the Denver aquifer, oxic conditions and the detection of several constituents associated with poor water quality or young water $\left(\mathrm{NO}_{3}, \mathrm{Se}\right.$, and $\left.\mathrm{U}\right)$ were more common in samples from the Arapahoe aquifer relative to those from the Denver aquifer (fig. 37). The Arapahoe aquifer has been the most heavily pumped of the bedrock aquifers (Paschke, 2011), and the differences in water quality for the Arapahoe aquifer relative to the Denver aquifer might result from enhanced pumpinginduced drawdown and transport of contaminants from overlying units. Fewer samples were collected for the Denver aquifer $(\mathrm{n}=10)$, however, than for the Arapahoe aquifer $(\mathrm{n}=$ 29 ), so these differences in water quality might also be biased by the number of samples collected from each bedrock aquifer (table 5).

As described by Paschke (2011), three general areas of recent development rely heavily on Denver Basin groundwater for municipal supply: the south Denver metropolitan area, the northern area, and the Monument area (fig. 6). The occurrence of oxic conditions and detections of ${ }^{3} \mathrm{H}$, which are indicative of the potential for mixing of bedrock aquifer groundwater with poor quality shallow groundwater, were evaluated spatially to assess potential effects of water use on water quality for the bedrock aquifers in these areas (fig. 38). Most (about 60 percent) bedrock-aquifer samples that were oxic or had ${ }^{3} \mathrm{H}$ concentrations of greater than $0.3 \mathrm{TU}$ were located within the three general areas of recent urban development associated with high groundwater usage, which indicates that water-use practices might be contributing to vulnerability of the bedrock aquifers to contamination. Additional samples meeting these criteria, however, were located outside the areas of high groundwater usage; most of these samples were from the Dawson aquifer, which as previously noted in this section is particularly vulnerable to contamination from mixing with shallow groundwater. The occurrence of several additional wells in the Denver and Arapahoe aquifers meeting these criteria but located outside the areas of high groundwater usage might reflect local pumping or land-use practices, which potentially could allow for transport of contaminants from overlying units. These wells include, for example, ARAPMAS 24 in the southern part of the study area, which as noted earlier was categorized as young groundwater with detection of several VOCs, as well as $\mathrm{NO}_{3}$, Se, and U. Studies in other aquifers have demonstrated that water-use and public-supply well practices can affect vulnerability and concentrations of constituents of concern (Eberts and others, 2013).

As noted earlier in this section, many of the constituents associated with poor water quality in the shallow aquifer system are affected by redox processes, and as a result, redox conditions in the bedrock aquifers might attenuate concentrations of constituents such as $\mathrm{DO}, \mathrm{NO}_{3}, \mathrm{U}, \mathrm{Se}, \mathrm{As}$, and some VOCs. Geochemical conditions, such as redox processes, have been found to be an important measure of contaminant mobility and persistence in aquifers across the Nation (Eberts and others, 2013). While the detection of some of these constituents in the bedrock aquifers might be indicative of vulnerability from mixing with downward moving shallow groundwater, it might also reflect localscale variability in redox processes or aquifer lithology. Additionally, the absence of some of these constituents in the bedrock aquifer might not necessarily reflect that mixing with downward moving shallow groundwater has not occurred but might reflect that, because these constituents are not conservative, concentrations have been attenuated as a result of redox processes. An evaluation of groundwater age categories for bedrock-aquifer samples relative to well depth, DO concentration, VOC detections, and well location (within or outside of high groundwater usage areas) indicates that no 


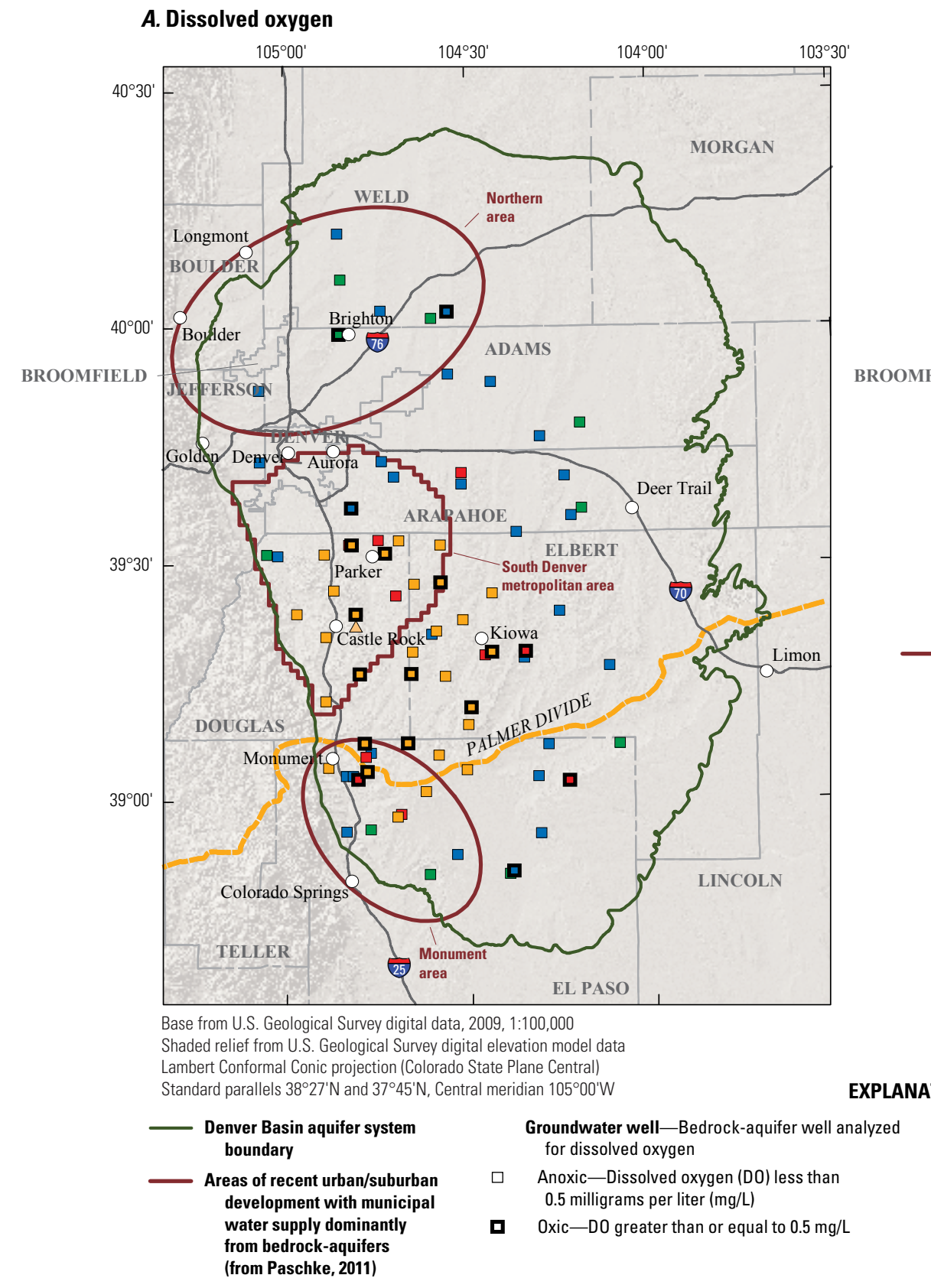

\section{B. Tritium}

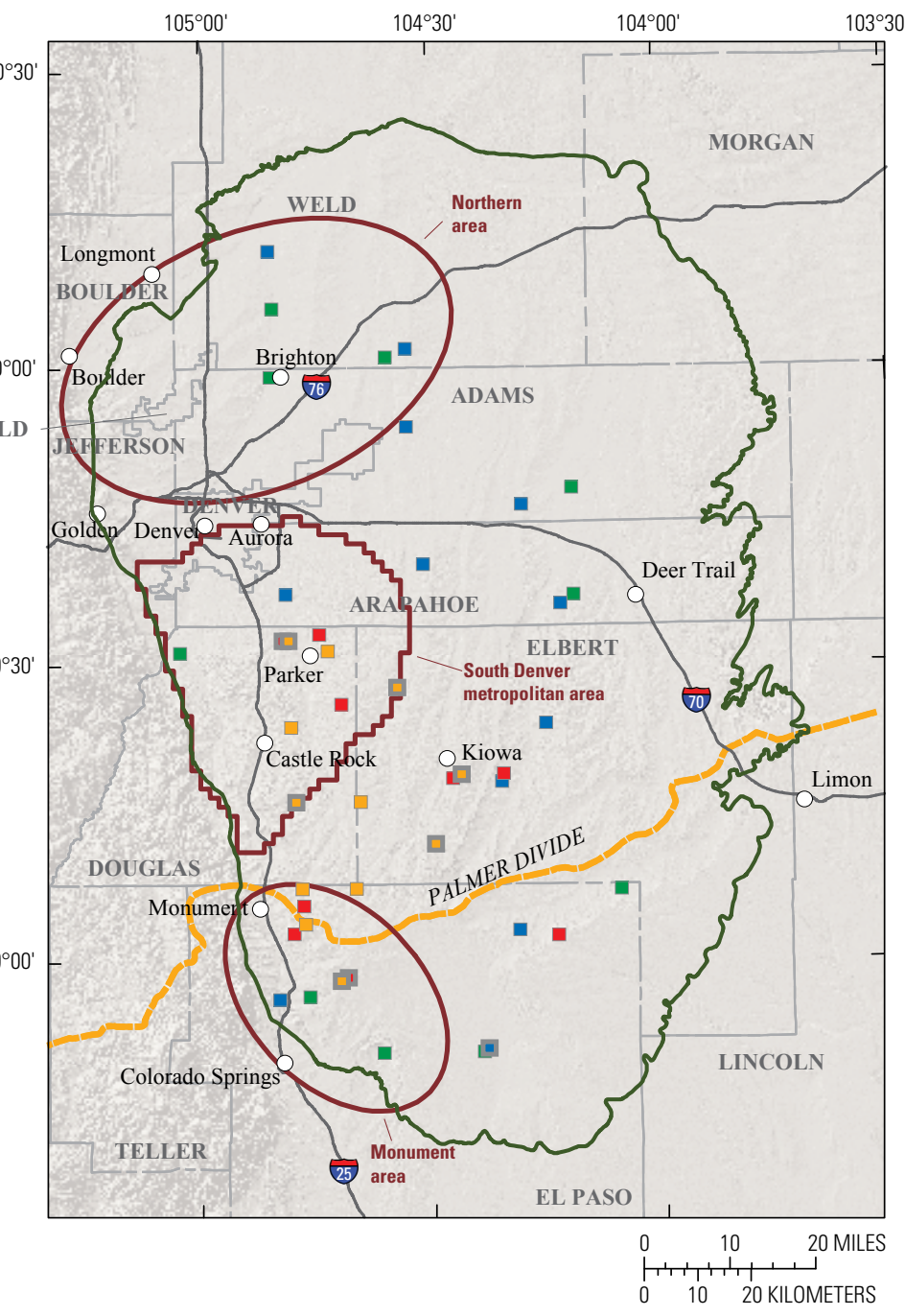

Groundwater well—Bedrock-aquifer well analyzed for tritium

Tritum

Denver Basin bedrock-aquifer well, by aquifer

- Tritium greater than or equal to 0.3 tritium units

- Dawson aquifer

- Denver aquifer

- Arapahoe aquifer

- Laramie-Fox Hills aquifer

Figure 38. Hydrogeologic setting and location of sampled wells with detections of selected water-quality constituents, Denver Basin aquifer system, Colorado, 2003-5. 
single criterion was consistently indicative of vulnerability to contaminants from shallow groundwater (fig. 39). For example, numerous samples categorized as old were oxic, from both within and outside of areas of high groundwater usage; oxic conditions occurred in old samples from relatively deep wells ( $>1,000 \mathrm{ft}$ below land surface), as well as from shallower wells; and VOCs were detected in oxic and anoxic samples and in relatively deep and shallow wells.

Evaluating the vulnerability of the bedrock aquifers is complex because of the nonconservative nature of many constituents of concern and requires consideration of multiple lines of evidence; measures of vulnerability for the Denver Basin should ideally include results for groundwater age tracers in combination with results for DO, nutrients, trace elements, and organic compounds. In spite of these complexities, results of the current study indicate that young groundwater of degraded quality from the shallow aquifer system has mixed with deeper bedrock aquifer groundwater in some locations and that the bedrock aquifers are vulnerable to natural and human contaminants.

\section{Denver Basin Groundwater Quality in a National Context}

Nationally consistent sampling protocols and analytical methods used by the NAWQA Program allow for comparison of Denver Basin study results with those obtained across the Nation. Previous assessments of water quality for many aquifer systems have indicated that shallow groundwaterparticularly from unconfined aquifers - is generally more vulnerable to contamination from human activities at the land surface than is deep groundwater from confined aquifers (Toccalino and Hopple, 2010). Results for the Denver Basin are consistent with these national observations.

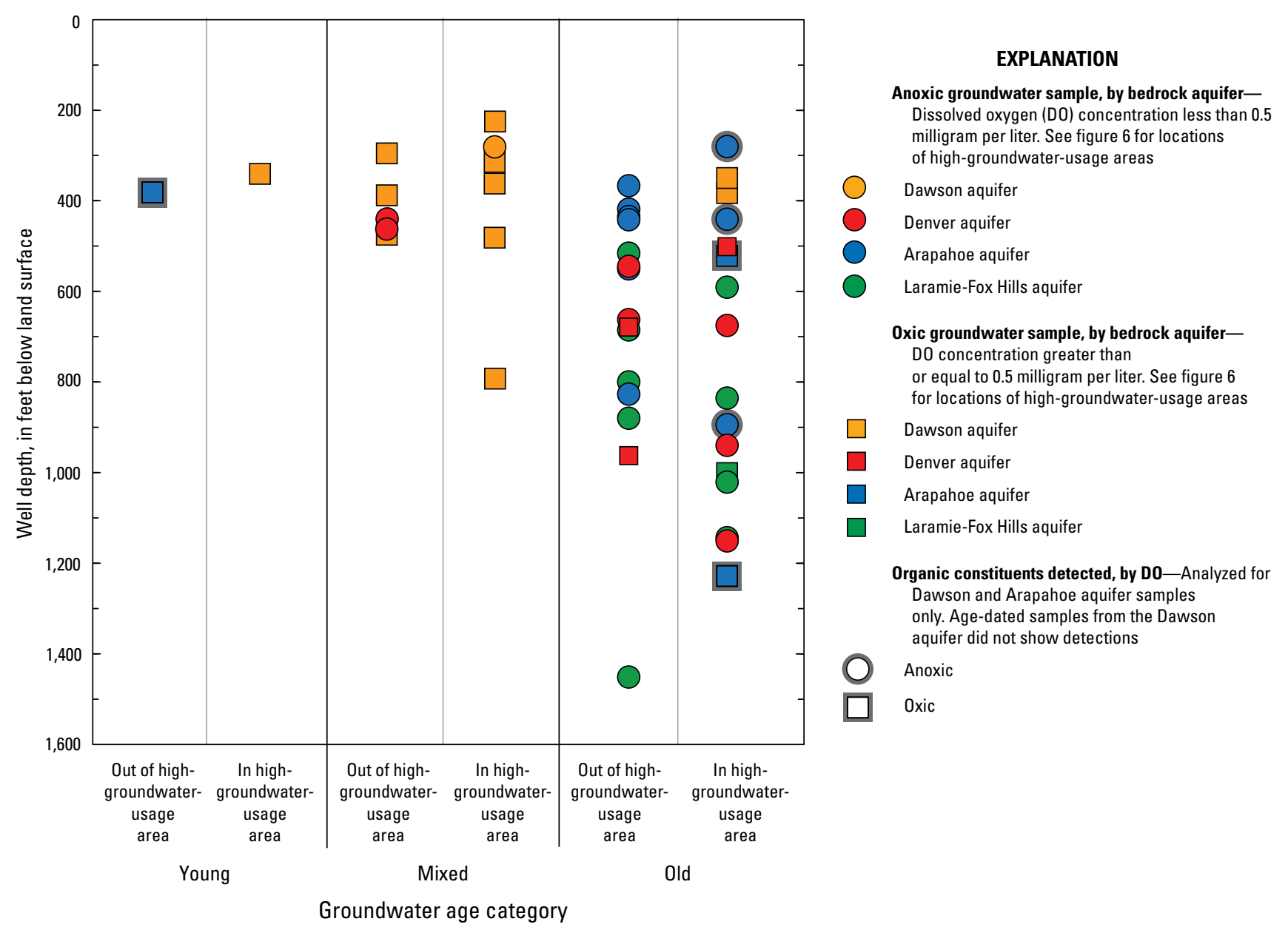

Figure 39. Relation between well depth and groundwater age interpretation category for groundwater samples, distinguished by dissolved oxygen concentration and detections of volatile organic compounds, Denver Basin aquifer system, Colorado, 2003-5. 
Results of the current study were compared with other NAWQA Program studies with similar land-use and aquifer settings to evaluate results for the Denver Basin in a national context (fig. 40). Bedrock aquifers were compared with other sandstone aquifers sampled by the NAWQA Program from 1991 to 2010. Results for the water-table wells were compared with results for shallow groundwater in agricultural and urban areas.

Relative to similar land-use settings, shallow Denver Basin groundwater tended to have higher concentrations of many constituents of concern. Concentrations of some natural contaminants, such as Se and $\mathrm{U}$, are likely affected by sediments and minerals in the Denver Basin that interact with recharge water as it infiltrates toward the water table. Resulting Se and U concentrations for samples from Denver Basin water-table wells more frequently exceeded their respective MCLs than in similar land-use settings (fig. 40). Additionally, concentrations of TDS, $\mathrm{SO}_{4}, \mathrm{Cl}$, and $\mathrm{Mn}$ exceeded their respective SMCLs more frequently for samples from Denver Basin water-table wells (fig. 40). Increased application of irrigation water in the Denver Basin has helped move these constituents from soils and unsaturated sediment, with subsequent evaporative concentration in shallow groundwater, contributing to the relatively high percentage of exceedances of water-quality benchmarks.

Relative to other sandstone aquifers nationwide, water quality of the Denver Basin bedrock aquifers is similar to or has lower percentages of benchmark exceedances for most constituents (fig. 40). Concentrations of four constituents with drinking-water MCLs- $\mathrm{Rn}$ (proposed MCL), $\mathrm{NO}_{3}$, As, and
$\mathrm{Se}$ - exceeded their respective MCLs in some samples from the bedrock aquifers. Of these constituents, only the lower of the two proposed MCLs for Rn had exceedances that occurred in more than 5 percent of samples. These results are consistent with the generally good quality of drinking-water resources of the bedrock aquifers.

No organic compound was detected in the Denver Basin aquifer system at a concentration that exceeded humanhealth benchmarks. Detections of organic contaminants in the Denver Basin were similar to national results, with respect to compounds that were detected. Chloroform, which has been linked to factors associated with urban development, was the most frequently detected VOC in samples from water-table wells in the Denver Basin and for agricultural and urban land-use areas nationwide (Zogorski and others, 2006). For pesticides, atrazine, its degradate deethylatrazine, and prometon were detected more frequently than other pesticide compounds in the Denver Basin and were mostly associated with shallow groundwater from the water-table wells (fig. 27). These findings were consistent with samples collected from agricultural and urban land-use areas nationwide, where these compounds are frequently detected (Gilliom and others, 2006). Nationally, four organic compounds (PCE, chloroform, diazinon, and dieldrin) have been detected at concentrations that exceeded MCLs or HBSLs for samples from drinkingwater wells completed in sandstone aquifers (Zogorski and others, 2006). Of these compounds, only chloroform was detected in samples from the Denver Basin bedrock aquifers, and it was detected at concentrations less than the MCL for total trihalomethanes (table 9). 
$\boldsymbol{A}$

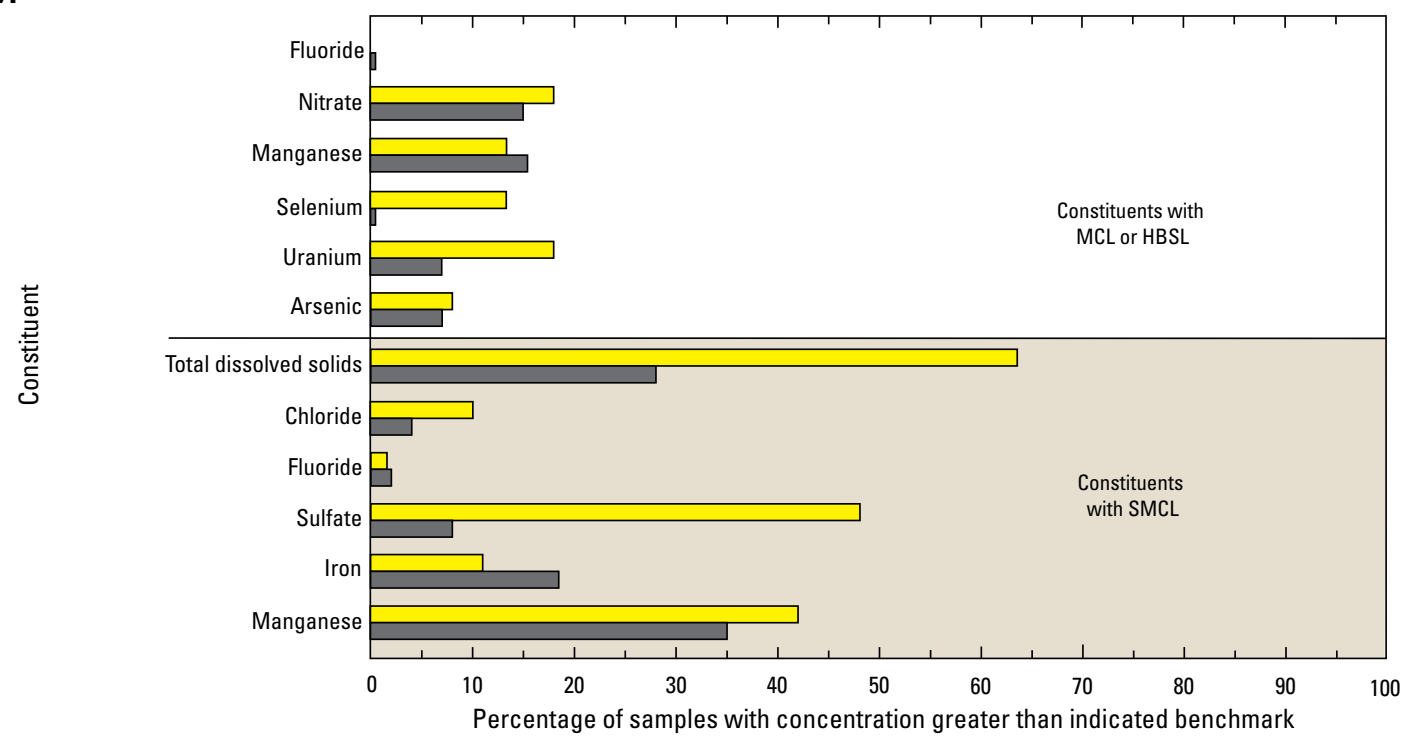

EXPLANATION

Shallow groundwater in agricultural

and urban land-use areas

Denver Basin

Other areas in the United States

MCL, maximum contaminant level

HBSL, health-based screening level

SMCL, secondary maximum contaminant level

B

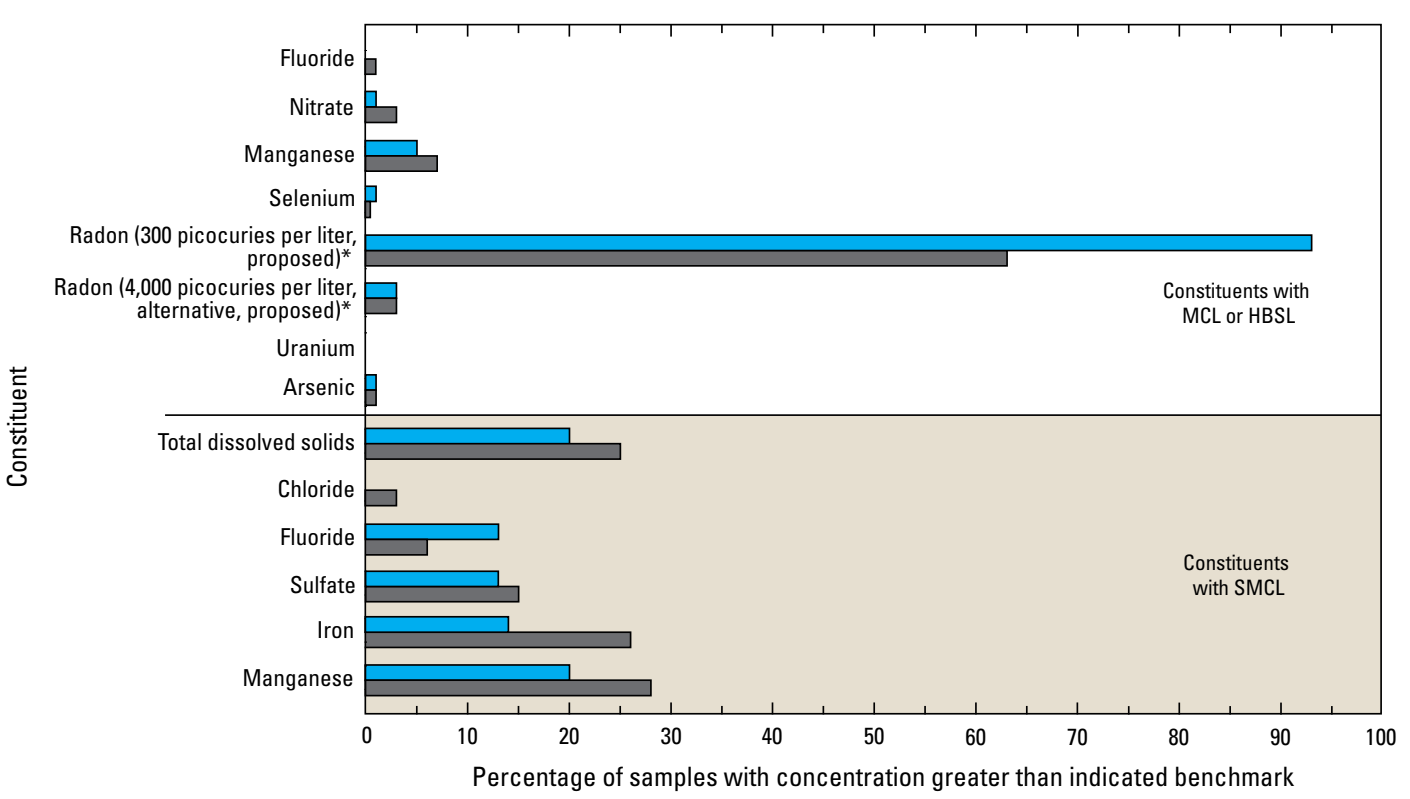

EXPLANATION

Sandstone aquifers

Denver Basin bedrock aquifers

$\square$ Other sandstone aquifers in the United States

MCL, maximum contaminant level

HBSL, health-based screening level

SMCL, secondary maximum contaminant level

*Only Dawson and Arapahoe aquifers sampled for

radon. The radon $\mathrm{MCL}$ and alternative $\mathrm{MCL}$ are proposed

levels (U.S. Environmental Protection Agency, 2013).

Figure 40. Comparison of selected water-quality results from the National Water-Quality Assessment Program, 1991-2010, with samples from the Denver Basin aquifer system, Colorado, 2003-5. $A$, Water-table wells in areas of agricultural and urban land use. $B$, Drinking-water wells completed in sandstone aquifers. 


\section{Summary}

The alluvial and bedrock aquifers of the Denver Basin (the Denver Basin aquifer system) provide critical water resources for municipal, domestic, and agricultural irrigation uses in Colorado along the eastern front of the Rocky Mountains. Understanding the quality of groundwater in the Denver Basin is important for human and aquatic ecosystem health and management and protection of the available resource. From 2003-5 the National Water-Quality Assessment Program of the U.S. Geological Survey conducted groundwater-quality studies in the Denver Basin aquifer system. Water-quality constituents of concern in the Denver Basin aquifer system for human health or because they might otherwise limit use of water include total dissolved solids, fluoride, sulfate, nitrate, iron, manganese, selenium, radon, uranium, arsenic, pesticides, and volatile organic compounds. Samples were collected from shallow monitoring wells (watertable well samples) installed to characterize water quality at the water table beneath agricultural (31 wells; predominantly non-irrigated wheat) and urban (29 wells) land uses; samples were collected from either the alluvial aquifer or near-surface bedrock, depending on where the water table was encountered. Samples were also collected from domestic- and municipalwater-supply wells from each of the four underlying bedrock aquifers (bedrock-aquifer samples). From stratigraphically youngest (shallowest) to oldest (deepest), these are the Dawson, Denver, Arapahoe, and Laramie-Fox Hills aquifers.

The extensive dataset collected from the bedrock aquifers (79 samples) provides the opportunity to evaluate the factors and processes that affect groundwater quality in the Denver Basin and to establish a baseline that can be used to characterize future changes in groundwater quality. The Denver Basin is an area of rapid urban development located mostly within the lower South Platte River Basin, which is an important agricultural area. Much of the population increase resulting from urban development of the past few decades depends on groundwater for water supply. Although precipitation is the primary natural source of recharge to the aquifer system, urban development and agricultural practices have resulted in increased irrigation in support of crops, lawns, and other landscape application. Water in the alluvial aquifer is primarily derived from the infiltration of surface water from streams and of irrigation water. Discharge from the Denver Basin aquifers occurs naturally as evapotranspiration, as flows to streams and springs, and as interaquifer flow. Urban development on the land surface has increased the amount of water moving through the aquifer system in response to increased irrigation, as well as increased demands on groundwater resources and associated increased pumping from municipal and domestic wells. As a result, the vulnerability of the groundwater near the water table and in the drinkingwater aquifers to natural and human-sourced contaminants has increased.

Groundwater samples were analyzed for major ions, nutrients, and trace elements. Additionally, selected samples were analyzed for isotopes of hydrogen, oxygen, and carbon; radionuclides; pesticides; volatile organic compounds; and groundwater age tracers. Age-tracer analyses included chlorofluorocarbons, associated dissolved gases, tritium, and carbon-14. This report describes these water-quality data, documents the occurrence and distribution of selected chemical characteristics, evaluates factors that control the spatial and depth variability of water quality, and synthesizes the findings to assess the vulnerability of the aquifer system and in particular the bedrock aquifers to groundwater contamination from contaminants in geologic materials and those of human origin.

Groundwater samples spanned a broad range of compositions; major-ion chemistry generally evolved from a calcium-bicarbonate composition to a calcium-sulfate composition, with some sodium-bicarbonate and sodiumsulfate compositions in the deeper bedrock aquifers. Concentrations of total dissolved solids and most major ions were generally higher for samples from the water-table wells, where water is primarily derived from the infiltration of surface water from streams and from irrigation water. Evaporative concentration of irrigation recharge concentrates dissolved salts and minerals in the shallow subsurface, where subsequent leaching provides sources of dissolved constituents to shallow groundwater. Total dissolved solids and sulfate concentrations exceeded water-quality standards for about half or more of samples from the water-table wells. In the bedrock aquifers, groundwater compositions also varied spatially: concentrations of total dissolved solids generally increased from the shallower to deeper bedrock aquifers and along groundwater flow paths to the north and east. This geochemical evolution likely results from longer residence times and reactions such as ion-exchange processes associated with the deeper bedrock aquifers. Changes in concentrations of calcium and sodium with depth indicate that ion-exchange processes are an important influence on major-ion chemistry in the bedrock aquifers. Oxidationreduction conditions generally evolve from oxic at the water table to anoxic with increasing depth in the bedrock aquifers. Several samples from the Arapahoe, Denver, and LaramieFox Hills aquifers, however, were oxic, which might reflect mixing with shallow oxic recharge in some locations. The decrease in dissolved oxygen concentrations with depth in the bedrock aquifers was accompanied by a decrease in nitrate concentration, an increase in $\mathrm{pH}$, and an increase in alkalinity concentration. Eighteen percent of the water-table well samples exceeded the maximum contaminant level for nitrate. High nitrate concentrations for the shallow aquifer are at least partially associated with urban and agricultural land uses and water-quality degradation of alluvial groundwater. One bedrock-aquifer sample (1 percent), from a relatively shallow (140 feet below land surface) Arapahoe aquifer well (ARAPMAS 07), exceeded the maximum contaminant level for nitrate. Relatively low nitrate concentrations in the bedrock aquifers are likely influenced by oxidation-reduction conditions and might also be influenced by the presence of older groundwater that recharged prior to extensive nitrate loading to groundwater in the region. 
Concentrations of several trace elements of concern with respect to water quality - selenium, uranium, and arsenic decreased with depth. These trace elements are present naturally in the sediments and rocks of the Denver Basin, and their concentrations in drinking water are of concern for human-health effects. Exceedances of water-quality standards for trace elements, including selenium, uranium, arsenic, iron, and manganese, were more frequent for samples from the water-table wells than for samples from the bedrockaquifer wells. Discharge of shallow groundwater has been identified as a source of selenium to surface water in the region and has resulted in several Denver Basin streams being classified as impaired because selenium concentrations have exceeded aquatic-life standards established by the State of Colorado. For the water-table wells, 18, 27, and 8 percent of samples exceeded the maximum contaminant levels for selenium $(50 \mu \mathrm{g} / \mathrm{L})$, uranium $(30 \mu \mathrm{g} / \mathrm{L})$, and arsenic $(10 \mu \mathrm{g} / \mathrm{L})$, respectively. Increased application of irrigation water and evaporation in the subsurface have likely mobilized these constituents. Conversely, for the bedrock aquifers, 1 percent or less of samples exceeded maximum contaminant levels for selenium, uranium, or arsenic. Concentrations of these and other constituents were generally transitional for the Dawson aquifer, the shallowest of the bedrock aquifers, with intermediary values between those for the water-table wells and the deeper bedrock aquifers. Radon was measured for bedrock-aquifer samples from the Dawson and Arapahoe aquifers, with a higher median concentration for the Dawson aquifer. Exceedance of the lower proposed Rn maximum contaminant level was widespread (greater than 90 percent) in both aquifers; for the higher proposed standard, exceedances were less than 5 percent.

A total of 8 pesticide compounds and 17 volatile organic compounds were detected in the aquifer system, all at concentrations that were generally orders of magnitude less than the associated standards for those constituents with benchmarks. Detections of pesticides and volatile organic compounds, which are indicative of human-sourced contaminants, occurred more frequently in samples from the water-table wells, with detections in 33 and 62 percent of samples, respectively (volatile organic compounds were not analyzed for agricultural land-use samples). The most frequently detected pesticide compounds for the watertable wells were atrazine, its degradate deethylatrazine, and prometon; chloroform was the most frequently detected volatile organic compound. The relatively common detection of several organic compounds in samples from the watertable wells is indicative of relatively young groundwater and of the vulnerability of shallow groundwater to humansourced contamination. Although found less frequently than in samples from the water-table wells, several pesticides and volatile organic compounds were detected in samples from the bedrock aquifers (analyzed for the Dawson and Arapahoe aquifers only). Pesticides were detected in two samples ( 3 percent) from the bedrock aquifers, both from the Dawson aquifer. Volatile organic compounds were detected in 22 percent of bedrock-aquifer samples, with more frequent detections for the stratigraphically deeper Arapahoe aquifer. Detections of carbon disulfide, the most frequent detected volatile organic compound for the bedrock aquifers, likely resulted from natural sources. More frequent volatile organic compound detections for the Arapahoe aquifer relative to the Dawson aquifer might partially reflect the downward flow of shallow groundwater and associated contaminants to the deeper aquifer in some areas resulting from high pumping rates.

Stable isotope results were indicative of meteoric recharge to the aquifer system, with some of the water-table well samples affected by evaporation. Stable isotope values generally increased (that is, were isotopically heavier) with depth in the bedrock aquifers. Some samples with heavier values were located from recharge areas near the Palmer Divide in the southern part of the study area.

Results for groundwater age tracers were integrated to group samples into categories of young (post-1950s recharge), mixed (a binary mixture of young and old [pre-1950s] recharge), and old; for many old samples, the groundwater is likely thousands of years old. Dominantly young groundwater associated with the water-table wells transitioned to dominantly old groundwater in the deeper bedrock aquifers. There were several notable exceptions to these generalizations, with 1 sample from the Arapahoe aquifer categorized as young and 2 samples from the Denver aquifer categorized as mixed.

Water-quality data were synthesized to evaluate factors that affect spatial and depth variability in water quality and to assess aquifer vulnerability to contaminants from geologic materials and those of human origin. The development of agricultural and urban and suburban areas has increased the vulnerability of Denver Basin groundwater to contamination. Water quality of shallow groundwater in the basin is degraded, as evidenced by relatively high concentrations of total dissolved solids and several constituents of concern with respect to drinking-water standards. Concentrations of most constituents associated with water-quality degradation in the water-table wells decreased with depth. Deep confined groundwater is often considered isolated and resistant to effects from human activities on the land surface and has historically been a source of high-quality drinking water in the Denver Basin. Nonetheless, several lines of evidence indicate that young, contaminant-bearing recharge has reached shallow to moderate depths in some parts of the bedrock aquifers. The stratigraphically shallowest bedrock aquifer, the Dawson aquifer, in particular, is vulnerable to contamination from natural and human sources. In the stratigraphically deeper bedrock aquifers, constituents of concern for water-quality degradation occurred less frequently and at lower concentrations, indicating that these aquifers were less vulnerable to contamination. Not all groundwater in the deeper bedrock aquifers is old, however, and mixing with young recharge has occurred locally in some locations. Spatial variability in bedrock-aquifer use and pumping might partially contribute to the potential migration of solutes 
and contaminants from the shallow aquifer system to the bedrock aquifers. Many of the constituents associated with poor water quality in the shallow aquifer system are affected by oxidation-reduction conditions, which are not generally conducive to the migration or persistence of many constituents of concern in the deeper bedrock aquifers. As a result, evaluating the vulnerability of the bedrock aquifers is complex because of the nonconservative nature of many constituents and requires consideration of multiple lines of evidence. Results of this study were compared with other studies with similar land-use and aquifer settings. Relative to similar land-use settings, shallow Denver Basin groundwater tended to have higher concentrations of many constituents of concern for human health, including selenium and uranium, which have local natural sources. Relative to other sandstone aquifers nationwide, the bedrock aquifers have similar water quality, indicative of generally good quality drinking-water resources.

\section{References Cited}

Agency for Toxic Substances and Disease Registry, 1996, Toxicological profile for carbon disulfide: U.S. Government Printing Office 1996-739-324, 219 p., accessed March 26, 2013, at http://www.atsdr.cdc.gov/ToxProfiles/tp82.pdf.

American Public Health Association, 1998, Standard methods for the examination of water and wastewater (20th ed.): Washington, D.C., American Public Health Association, American Water Works Association, and Water Environment Federation, 1,220 p.

Anderman, G.G., and Ackman, E.J., 1963, Structure of the Denver-Julesburg Basin and surrounding areas, in Guidebook to the geology of the northern Denver Basin and adjacent uplifts: Rocky Mountain Association of Geologists, p. $170-175$.

Appelo, C.A.J., and Postma, Dieke, 2005, Geochemistry, groundwater, and pollution ( $2 \mathrm{~d}$ ed.): A.A. Balkema Publishers, $649 \mathrm{p}$.

Ayotte, J.D., Gronberg, J.M., and Apodaca, L.E., 2011, Trace elements and radon in groundwater across the United States, 1992-2003: U.S. Geological Survey Scientific Investigations Report 2011-5059, 115 p.

Ayotte, J.D., Szabo, Zoltan, Focazio, M.J., and Eberts, S.M., 2011, Effects of human-induced alteration of groundwater flow on concentrations of naturally-occurring trace elements at water-supply wells: Applied Geochemistry, v. 26, p. 747-762.

Bailey, R.T., Hunter, W.J., and Gates, T.K., 2012, The influence of nitrate on selenium in irrigated agricultural groundwater systems: Journal of Environmental Quality, v. 41, p. $783-792$.
Bails, J.B., Deitsch, B.J., Landon, M.K., Paschke, S.S., 2009, Occurrence of selected organic compounds in groundwater used for public supply in the Plio-Pleistocene deposits of east-central Nebraska and the Dawson and Denver aquifers near Denver, Colorado, 2002-2004: U.S. Geological Survey Scientific Investigations Report 2008-5243, 29 p. with appendixes.

Bender, D.A., Zogorski, J.S., Mueller, D.K., Rose, D.L., Martin, J.D., and Brenner, C.K., 2011, Quality of volatile organic compound data from groundwater and surface water for the National Water-Quality Assessment Program, October 1996-December 2008: U.S. Geological Survey Scientific Investigations Report 2011-5204, 128 p.

Bethke, C.M., and Johnson, T.M., 2008, Groundwater age and groundwater age dating: Annual Reviews of Earth and Planetary Science, v. 36, p. 121-152.

Bexfield, L.M., Jurgens, B.C., Crilley, D.M., and Christenson, S.C., 2012, Hydrogeology, water chemistry, and transport processes in the zone of contribution of a public-supply well in Albuquerque, New Mexico, 2007-9: U.S. Geological Survey Scientific Investigations Report 2011-5182, 114 p.

Bjorklund, L.J., and Brown, R.F., 1957, Geology and groundwater resources of the lower South Platte River valley between Hardin Colorado and Paxton, Nebraska: U.S. Geological Survey Water-Supply Paper 1378, 438 p.

Boberg, W.W., and Runnells, D.D., 1971, Reconnaissance study of uranium in the South Platte River, Colorado: Economic Geology, v. 66, p. 435-450.

Böhlke, J.K., 2006, Tracermodel 1. Excel workbook for calculation and presentation of environmental tracer data for simple groundwater mixtures, in Use of chlorofluorocarbons in hydrology - A guidebook, Vienna, Austria, International Atomic Energy Agency, STI/PUB/1238, 277 p.

Böhlke, J.K., Révész, Kinga, Busenberg, Eurybiades, Deák, József, Deseö, Evá, and Stute, Martin, 1997, Groundwater record of halocarbon transport by the Danube River, Environmental Science and Technology, v. 31, p. 3293 3299.

Brenton, R.W., and Arnett, T.L., 1993, Methods of analysis by the U.S. Geological Survey National Water Quality Laboratory-Determination of dissolved organic carbon by UV-promoted persulfate oxidation and infrared spectrometry: U.S. Geological Survey Open-File Report 92-480, 12 p.

Bruce, B.W., and McMahon, P.B., 1998, Shallow groundwater quality of selected land-use/aquifer settings in the South Platte River Basin, Colorado and Nebraska, 1993-95: U.S. Geological Survey Water-Resources Investigations Report 97-4229, 48 p. 
Bullister, J.L., 1984, Atmospheric chlorofluoromethanes as tracers of ocean circulation and mixing-Studies in the Greenland and Norwegian seas: La Jolla, University of California San Diego, Ph.D. dissertation, 172 p.

Bullister, J.L., and Weiss, R.F., 1988, Determination of $\mathrm{CFC}_{3} \mathrm{~F}$ and $\mathrm{CCl}_{2} \mathrm{~F}_{2}$ in seawater and air: Deep Sea Research, v. 35, p. $839-854$.

Busenberg, Eurybiades, and Plummer, L.N., 1992, Use of chlorofluorocarbons $\left(\mathrm{CCl}_{3} \mathrm{~F}\right.$ and $\left.\mathrm{CCl}_{2} \mathrm{~F}_{2}\right)$ as hydrologic tracers and age-dating tools-The alluvium and terrace system of central Oklahoma: Water Resources Research, v. 28 , p. $2257-2283$.

Busenberg, Eurybiades, Weeks, E.P., Plummer, L.N., and Bartholomay, R.C., 1993, Age dating ground water by use of chlorofluorocarbons $\left(\mathrm{CCl}_{3} \mathrm{~F}\right.$ and $\left.\mathrm{CCl}_{2} \mathrm{~F}_{2}\right)$, and distribution of chlorofluorocarbons in the unsaturated zone, Snake River Plain aquifer, Idaho National Engineering Laboratory, Idaho: U.S. Geological Survey, Water-Resources Investigations Report 93-4054, $47 \mathrm{p}$.

Chapelle, F.J., McMahon, P.B., Dubrovsky, N.M., Fujii, R.F., Oaksford, E.T., and Vroblesky, D.A., 1995, Deducing the distribution of terminal electron-accepting processes in hydrologically diverse groundwater systems: Water Resources Research, v. 31, p. 359-371.

Childress, C.J.O., Foreman, W.T., Connor, B.F., and Maloney, T.J., 1999, New reporting procedures based on long-term method detection levels and some considerations for interpretations of water-quality data provided by the U.S. Geological Survey National Water Quality Laboratory: U.S. Geological Survey Open-File Report 99-193, 19 p.

Chin, Mian, and Davis, D.D., 1993, Global sources and sinks of OCS and $\mathrm{CS}_{2}$ and their distributions: Global Biogeochemical Cycles, v. 7, p. 321-337.

Clark, P.F., and Fritz, I.D., 1997, Environmental isotopes in hydrogeology; New York, N.Y., CRC Press, 328 p.

Colorado Department of Public Health and Environment, 2010, Regulation No. 93 - Colorado's section 303(d) list of impaired waters and monitoring and evaluation list: Colorado Department of Public Health and Environment, Water Quality Control Commission, 62 p., accessed October 11, 2011, at http://www.cdphe.state.co.us/regulations/wqccr egs/100293wqlimitedsegtmdlsnew.pdf.

Colorado Department of Public Health and Environment, 2013, Regulation No. 31-The basic standards and methodologies for surface water: Colorado Department of Public Health and Environment, Water Quality Control Commission Regulations, accessed January 24, 2013, at http://www.colorado.gov/cs/Satellite?c=Page\&childpagena $\mathrm{me}=$ CDPHE-Main\%2FCBONLayout\&cid $=1251595703337$ \&pagename $=\mathrm{CBONWrapper}$.
Colorado Division of Water Resources, 1998, Denver Basin and South Platte River Basin technical study: Final Report Senate Bill 96-074, variously paged.

Colorado Division of Water Resources, 2010, Ground water administration and well permitting: Accessed March 8, 2010, at http://water.state.co.us/groundwater/groundwater. asp.

Colorado Division of Water Resources, 2012, Colorado's well permit search: Accessed October 25, 2012, at http://www. dwr.state.co.us/WellPermitSearch/default.aspx.

Colorado Water Conservation Board, 2004, Statewide water supply initiative report-November 2004: variously paginated, accessed March 19, 2009, at http://cwcb.state. co.us/IWMD/SWSITechnicalResources/SWSIPhaseIReport/ SWSIPhaseIReport.htm.

Connor, B.F., Rose, D.L., Noriega, M.C., Murtagh, L.K., and Abney, S.R., 1998, Analysis by the U.S. Geological Survey National Water Quality Laboratory-Determination of 86 volatile organic compounds in water by gas chromatography/mass spectrometry, including detections less than reporting limits: U.S. Geological Survey OpenFile Report 97-829, 78 p.

Cook, P.G., and Böhlke, J.K., 2000, Determining timescales for groundwater flow and solute transport, in Cook, P.G., and Herczeg, A.L., eds., Environmental tracers in subsurface hydrology: Boston, Mass., Kluwer Academic Publishers, p. 1-30.

Cook, P.G., Plummer, L.N., Solomon, D.K., Busenberg, Eurybiades, and Han, L.F., 2006, Effects and processes that can modify apparent CFC age, in Use of chlorofluorocarbons in hydrology - A guidebook: Vienna, Austria, International Atomic Energy Agency, STI/ PUB/1238, $277 \mathrm{p}$.

Coplen, T.B., Hopple, J.A., Böhlke, J.K., Peiser, H.S., Rieder, S.E., Krouse, H.R., Rosman, K.J.R., Ding, T., Vocke, R.D., Jr., Révész, K.M., Lamberty, A., Taylor, P.D.P., and De Bièvre, P., 2002, Compilation of minimum and maximum isotope ratios of selected elements in naturally occurring terrestrial materials and reagents: U.S. Geological Survey Water-Resources Investigations Report 01-4222, 98 p.

Coplen, T.B., Wildman, J.D., and Chen, J., 1991, Improvements in the gaseous hydrogen-water equilibration technique for hydrogen isotope ratio analysis: Analytical Chemistry, v. 63, p. 910-912.

Craig, Harmon, 1961, Isotopic variations in meteoric waters: Science, v. 133, p. 1702-1703.

Davis, J.G., and Westfall, D.G., 2009a, Fertilizing corn: Colorado State University Extension, Fact Sheet no. 0.538, accessed August 16, 2013, at http://www.ext.colostate.edu/ pubs/crops/00538.html. 
Davis, J.G., and Westfall, D.G., 2009b, Fertilizing winter wheat: Colorado State University Extension, Fact Sheet no. 0.544, accessed August 16, 2013, at http://www.ext. colostate.edu/pubs/crops/00544.html.

Dennehy, K.F., Litke, D.W., Tate, C.M., Qi, S.L., McMahon, P.B., Bruce, B.W., Kimbrough, R.A., and Heiny, J.S., 1998, Water quality in the South Platte River Basin, Colorado, Nebraska, and Wyoming, 1992-95: U.S. Geological Survey Circular 1167, $38 \mathrm{p}$.

Devai, Istvan, and DeLaune, R.D., 1995, Formation of volatile sulfur compounds in salt marsh sediment as influenced by soil redox condition: Organic Geochemistry, v. 23, no. 4, p. 283-287.

Drimmie, R.J., Heemskerk, A.R., and Aravena, R.O., 1994, Dissolved inorganic carbon (DIC), technical procedure 5.0, rev. 02, Environmental Isotope Laboratory: Waterloo, Ontario, Department of Earth Sciences, University of Waterloo, $7 \mathrm{p}$.

Driscoll, L.B., 1974, Land-use classification map of the Boulder-Fort Collins-Greeley area, Front Range Urban Corridor: U.S. Geological Survey Miscellaneous Investigation Series Map I-855-B, 1 sheet.

Driscoll, L.B., 1975, Land-use classification map of the Colorado Springs-Castle Rock area, Front Range Urban Corridor: U.S. Geological Survey Miscellaneous Investigation Series Map I-857-B, 1 sheet.

Dubrovsky, N.M., Burow, K.R., Clark, G.M., Gronberg, J.M., Hamilton P.A., Hitt, K.J., Mueller, D.K., Munn, M.D., Nolan, B.T., Puckett, L.J., Rupert, M.G., Short, T.M., Spahr, N.E., Sprague, L.A., and Wilber, W.G., 2010, The quality of our Nation's waters-Nutrients in the Nation's streams and groundwater, 1992-2004: U.S. Geological Survey Circular $1350,174 \mathrm{p}$.

Eberts, S.M., Thomas, M.A., and Jagucki, M.L., 2013, The quality of our Nation's waters-Factors affecting publicsupply well vulnerability to contamination-Understanding observed water quality and anticipating future water quality: U.S. Geological Survey Circular, 1385, 120 p.

Edmunds, W.M., and Gaye, C.B., 1997, Naturally high nitrate concentrations in groundwaters from the Sahel: Journal of Environmental Quality, v. 26, p. 1231-1239.

Epis, R.C., Scott, G.R., Taylor, R.B., and Chapin, C.E., 1976, Cenozoic volcanic, tectonic, and geomorphic features of central Colorado, in Epis, R.C., and Weimer, R.J., eds., Professional Contributions of Colorado School of Mines Number 8: Studies in Colorado Field Geology, p. 23-338.

Epstein, S., and Mayeda, T., 1953, Variation of O-18 content of water from natural sources: Geochimica et Cosmochimica Acta, v. 4, p. 213-224.
Faires, L.M., 1993, Methods of analysis by the U.S. Geological Survey National Water Quality LaboratoryDetermination of metals in water by inductively coupled plasma-mass spectrometry: U.S. Geological Survey OpenFile Report 92-634, 28 p.

Fenneman, N.M., 1931, Physiography of the western United States: New York, McGraw-Hill, 534 p.

Fernández-Martínez, Alejandro, and Charlet, Laurent, 2009, Selenium environmental cycling and bioavailability-A structural chemist point of view: Reviews in Environmental Science and Biotechnology, v. 8, p. 81-110.

Fishman, M.J., ed., 1993, Methods of analysis by the U.S. Geological Survey National Water Quality LaboratoryDetermination of inorganic and organic constituents in water and fluvial sediments: U.S. Geological Survey OpenFile Report 93-125, $217 \mathrm{p}$.

Fishman, M.J., and Friedman, L.C., 1989, Methods for determination of inorganic substances in water and fluvial sediments: U.S. Geological Survey Techniques of WaterResources Investigations, book 5, chap. A1, 545 p.

Fram, M.S., Olsen, L.D., and Belitz, Kenneth, 2012, Evaluation of volatile organic compound (VOC) blank data and application of study reporting levels to groundwater data collected for the California GAMA Priority Basin Project, May 2004 through September 2010: U.S. Geological Survey Scientific Investigations Report 20125139, $94 \mathrm{p}$.

Fritz, Peter, and Fontes, J.C., eds., 1980, Handbook of environmental isotope geochemistry-The terrestrial environment: Amsterdam, Elsevier, v. 1, 545 p.

Furlong, E.T., Anderson, B.D., Werner, S.L., Soliven, P.P., Coffey, L.J., and Burkhardt, M.R., 2001, Methods of analysis by the U.S. Geological Survey National Water Quality Laboratory-Determination of pesticides in water by graphitized carbon-based solid-phase extraction and high-performance liquid chromatography/mass spectrometry: U.S. Geological Survey Water-Resources Investigations Report 01-4134, 73 p.

Galloway, J.N., Townsend, A.R., Erisman, J.W., Bekunda, M., Cai, Z., Freney, J.R., Martinelli, L.A., Seitzinger, S.P., and Sutton, M.A., 2008, Transformation of the nitrogen cycleRecent trends, questions, and potential solutions: Science, v. 320, p. 889-892.

Garbarino, J.R., 1999, Methods of analysis by the U.S. Geological Survey National Water Quality LaboratoryDetermination of dissolved arsenic, boron, lithium, selenium, strontium, thallium, and vanadium using inductively coupled plasma-mass spectrometry: U.S. Geological Survey Open-File Report 99-093, 31 p. 
Gat, J.R., and Gonfiantini, R., 1981, Stable isotope hydrology-Deuterium and oxygen-18 in the water cycle: IAEA Technical Report Series No. 210, International Atomic Energy Agency, Vienna, Austria, 339 p.

Gates, T.K., Cody, B.M., Donnelly, J.P., Herting, A.W., Bailey, R.T., and Price, J.M., 2009, Assessing selenium contamination in the irrigated stream-aquifer system of the Arkansas River, Colorado: Journal of Environmental Quality, v. 38, p. 2344-2356.

Gilliom, R.J., Alley, W.M., and Gurtz, M.E., 1995, Design of the National Water-Quality Assessment ProgramOccurrence and distribution of water-quality conditions: U.S. Geological Survey Circular 1112, 33 p.

Gilliom, R.J., Barbash, J.E., Crawford, C.G., Hamilton, P.A., Martin, J.D., Nakagaki, Naomi, Nowell, L.H., Scott, J.C., Stackelberg, P.E., Thelin, G.P., and Wolock, D.M., 2006, Pesticides in the Nation's stream and ground water, 19922001: U.S. Geological Survey Circular 1291, 172 p.

Graham, Glenn, and VanSlyke, George, 2004, Development of the regulatory framework for Denver Basin aquifers: The Mountain Geologist, v. 41, p. 153-160.

Graham, R.C., Hirmas, D.R., Wood, Y.A., and Amrhein, Christopher, 2008, Large near-surface nitrate pools in soils capped by desert pavement in the Mojave Desert, California: Geology, v. 36, p. 259-262.

Gurdak, J.J., and Qi, S.L., 2006, Vulnerability of recently recharged ground water in the High Plains aquifer to nitrate contamination: U.S. Geological Survey Scientific Investigations Report 2006-5050, 39 p.

Hansen, W.R., Chronic, J., and Matelock, J., 1978, Climatography of the Front Range Urban Corridor and vicinity, Colorado: U.S. Geological Survey Professional paper $1019,59 \mathrm{p}$.

Harvey, F.E., 2005, Stable hydrogen and oxygen isotope composition of precipitation in northeastern Colorado: Journal of the American Water Resources Association, April 2005, p. 447-459.

Helsel, D.R., and Hirsch, R.M., 2002, Hydrologic analysis and interpretation-Statistical methods in water resources: U.S. Geological Survey Techniques of Water-Resources Investigations, book 4, chap. A3, accessed September 2008 at http://pubs.usgs.gov/twri/twri4a3/html/pdf_new.html.

Hem, J.D., 1992, Study and interpretation of the chemical characteristics of natural water ( $3 \mathrm{~d}$ ed.): U.S. Geological Survey Water-Supply Paper 2254, 263 p.

Herring, J.R., and Walton-Day, Katherine, 2007, Selenium and other elements in water and adjacent rock and sediment of Toll Gate Creek, Aurora, Arapahoe County, Colorado, December 2003 through March 2004: U.S. Geological Survey Scientific Investigations Report 2007-5018, 58 p.
Hobbs, 2007, An overview of Colorado groundwater law, in Colorado water-Newsletter of the Water Center of Colorado State University: Fort Collins, Colo., Colorado State University Water Center, v. 24, no. 5, p. 2-5, accessed May 2012 at http://wsnet.colostate.edu/cwis31/ ColoradoWater/Images/Newsletters/2007/CW_24_5.pdf.

Homer, Collin, Huang, Chengquan, Yang, Limin, Wylle, Bruce, and Coan, Michael, 2004, Development of a 2001 National Land-Cover Database for the United States: Photogrammetric Engineering and Remote Sensing, July 2004, p. 829-840.

Hurr, R.T., Schneider, P.A., Jr., and Minges, D.R., 1975, Hydrology of the South Platte River valley, northeastern Colorado: Colorado Water Resources Circular 28.

Ivahnenko, Tamara, and Barbash, J.E., 2004, Chloroform in the hydrologic system - Sources, transport, fate, occurrence, and effects on human health and aquatic organisms: U.S. Geological Survey Scientific Investigations Report 20045137, $34 \mathrm{p}$.

Jurgens, B.C., Böhlke, J.K., and Eberts, S.M., 2012, TracerLPM (Version 1)-An Excel workbook for interpreting groundwater age distributions from environmental tracer data: U.S. Geological Survey Techniques and Methods Report 4-F3, $60 \mathrm{p}$.

Jurgens, B.C., Fram, M.S., Belitz, K., Burow, K.R., and Landon, M.K., 2010, Effects of groundwater development on uranium-Central Valley, California, USA:

Groundwater, v. 48, p. 913-928.

Jurgens, B.C., McMahon, P.B., Chapelle, F.H., and Eberts, S.M., 2009, An Excel workbook for identifying redox processes in groundwater: U.S. Geological Survey OpenFile Report 2009-1004, 8 p.

Keith, J.R., and Maberry, J.O., 1973, Vegetation map of the Parker Quadrangle, Arapahoe and Douglas Counties, Colorado: U.S. Geological Survey Folio of the Parker Quadrangle, Colorado, Map I-770-N, 1 sheet.

Koterba, M.T., 1998, Ground-water data-collection protocols and procedures for the National Water-Quality Assessment Program-Collection, documentation, and compilation of required site, well, subsurface, and landscape data for wells: U.S. Geological Survey Water-Resources Investigations Report 98-4107, $91 \mathrm{p}$.

Koterba, M.T., Wilde, F.T., and Lapham, W.W., 1995, Groundwater data-collection protocols and procedures for the National Water-Quality Assessment Program - Collection and documentation of water-quality samples and related data: U.S. Geological Survey Open-File Report 95-399, $133 \mathrm{p}$. 
Kyser, T.K., ed., 1987, Stable isotope geochemistry of low temperature processes: Short Course Handbook, Mineralogical Association of Canada, Saskatoon, Saskatchewan, v. 13, 452 p.

Lapham, W.W., Hamilton, P.A., and Myers, D.N., 2005, National Water-Quality Assessment Program-Cycle II Regional Assessments of Aquifers: U.S. Geological Survey Fact Sheet 2005-3013, 4 p.

Lapham, W.W., Wilde, F.D., and Koterba, M.T., 1995, Groundwater data-collection protocols and procedures for the National Water-Quality Assessment ProgramSelection, installation, and documentation of wells, and collection of related data: U.S. Geological Survey OpenFile Report 95-398, 69 p.

Lindley, C.E., Stewart, J.T., and Sandstrom, M.W., 1996, Determination of low concentrations of acetochlor in water by automated solid-phase extraction and gas chromatography with mass selective detection: Journal of Association of Official Analytical Chemists International, v. 79, p. 962-966.

Llopis, J.L., 1991, Effects of well casing material on ground water-quality: U.S. Environmental Protection Agency, Office of Research and Development, Office of Solid Waste and Emergency Response, Report number EPA/504/491/005, $15 \mathrm{p}$.

Lucas, L.L., and Unterweger, M.P., 2000, Comprehensive review and critical evaluation of the half-life of tritium: Journal of Research of the National Institute of Standards and Technology, v. 105, p. 541-549.

Madsen, J.E., Sandstrom, M.W., and Zaugg, S.D., 2003, Methods of analysis by the U.S. Geological Survey National Water Quality Laboratory-A method supplement for the determination of fipronil and degradates in water by gas chromatography/mass spectrometry: U.S. Geological Survey Open-File Report 02-462, 11 p.

McLain, B.J., 1993, Methods of analysis by the U.S. Geological Survey National Water Quality LaboratoryDetermination of chromium in water by graphite furnace atomic absorption spectrophotometry: U.S. Geological Survey Open-File Report 93-449, 16 p.

McMahon, P.B., and Böhlke, J.K., 1996, Denitrification and mixing in a stream-aquifer system-Effects on nitrate loading to surface water: Journal of Hydrology, v. 186, p. $105-128$.

McMahon, P.B., and Chapelle, F.H., 2008, Redox processes and water quality of selected principal aquifer systems: Ground Water, v. 46, p. 259-271.
McMahon, P.B., Cowdery, T.K., Chapelle, F.H., and Jurgens, B.C., 2009, Redox conditions in selected principal aquifers of the United States: U.S. Geological Survey Fact Sheet 2009-3041, 6 p.

Miller, L.D., Watts, K.R., Ortiz, R.F., and Ivahnenko, Tamara, 2010, Occurrence and distribution of dissolved solids, selenium, and uranium in groundwater and surface water in the Arkansas River Basin from the headwaters to Coolidge, Kansas, 1970-2009: U.S. Geological Survey Scientific Investigations Report 2010-5069, 59 p.

Moore, J.E., Raynolds, R.G., and Barkmann, P.E., 2004, Groundwater mining of bedrock aquifers in the Denver Basin —Past, present, and future: Environmental Geology, v. 47, p. 63-68.

Moore, J.E., Raynolds, R.G., and Dechesne, M., 2007, Bedrock aquifers and population growth in the Denver Basin, Colorado, USA: Episodes, v. 30, p. 115-118.

National Oceanic and Atmospheric Administration, 2004, Monthly surface data for Colorado 1931-2003: Accessed October 29, 2004, at http://www.ncdc.noaa.gov/oa/ncdc. html.

Nolan, B.T., Ruddy, B.C., Hitt, K.J., and Helsel, D.R., 1998, A national look at nitrate contamination of ground water: Water Conditioning and Purification, v. 39, p. 76-79.

Novotny, M.M., and Sanford, W.E., 2005, Groundwater residence time and recharge temperature estimates of the Denver and Arapahoe aquifers, Denver Basin, Colorado: The Mountain Geologist, v. 41, p. 161-167.

Nwangwu, Uka, 1977, Depositional environments, upper Pierre Shale, Denver Basin, Colorado: Rocky Mountain Association of Geologists, 1977 Symposium, p. 213-222.

Parkhurst, D.L., and Charlton, S.R., 2008, NetpathXL-An Excel interface to the program NETPATH: U.S. Geological Survey Techniques and Methods 6-A26, 11 p.

Paschke, S.S., ed., 2011, Groundwater availability of the Denver Basin aquifer system, Colorado: U.S. Geological Survey Professional Paper 1770, $274 \mathrm{p}$.

Paschke, S.S., Runkel, R.L., Walton-Day, Katherine, Kimball, B.A., and Schaffrath, K.R., 2013, Streamflow and water-quality conditions including geologic sources and processes affecting selenium loading in the Toll Gate Creek watershed, Aurora, Arapahoe County, Colorado, 2007: U.S. Geological Survey Scientific Investigations Report 20125280, $108 \mathrm{p}$.

Paschke, S.S., Schaffrath, K.R., and Mashburn, S.L., 2008, Near-decadal changes in nitrate and pesticide concentrations in the South Platte River alluvial aquifer, 1993-2004: Journal of Environmental Quality v. 37, p. S-281-S-295. 
Patton, C.J., and Kryskalla, J.R., 2003, Methods of analysis by the U.S. Geological Survey National Water Quality Laboratory - Evaluation of alkaline persulfate digestion as an alternative to Kjeldahl digestion for determination of total and dissolved nitrogen and phosphorus in water: U.S. Geological Survey Water-Resources Investigations Report 03-4174, $33 \mathrm{p}$.

Phillips, F.M., and Castro, M.C., 2003, Groundwater dating and residence-time measurements, in Holland, H.D., and Turekian, K.K., eds., Treatise on geochemistry-Surface and ground water, weathering, and soils, v. 5, Drever, J.I., volume ed.: Oxford, Oxford University Press, p. 451-497.

Piper, A.M., 1953, A graphic procedure in the geochemical interpretation of water analysis: U.S. Geological Survey Ground Water Note No. 12.

Plummer, L.N., 2005, Dating of young groundwater, in Aggarwal, P.K., Gat, J.R., and Froelich, K.F.O., eds., Isotopes in the water cycle-Past, present, and future of a developing science: Dordrecht, Netherlands, Springer, p. 193-220.

Plummer, L.N., Bexfield, L.M., Anderholm, S.K., Sanford, W.E., and Busenberg, Eurybiades, 2004, Geochemical characterization of groundwater flow in the Santa Fe Group aquifer system, Middle Rio Grande Basin, New Mexico: U.S. Geological Survey Water-Resources Investigations Report 03-4131, 395 p.

Plummer, L.N., and Busenberg, Eurybiades, 2005, Chlorofluorocarbons, in Cook, P.G., and Herczeg, A., eds., Environmental tracers in subsurface hydrology: Boston, Mass., Kluwer Academic Publishers, 552 p.

Plummer, L.N., and Busenberg, Eurybiades, 2008a, U.S. Geological Survey analytical procedures to analyze dissolved gas, accessed March 20, 2008, at http://water. usgs.gov/lab/dissolved-gas/lab/analytical_procedures/.

Plummer, L.N., and Busenberg, Eurybiades, 2008b, U.S. Geological Survey analytical procedures to analyze chlorofluorocarbons, accessed March 20, 2008, at http://water.usgs.gov/lab/chlorofluorocarbons/lab/ analytical_procedures/.

Plummer, L.N., and Friedman, L.C., 1999, Tracing and dating young ground water: U.S. Geological Survey Fact Sheet 134-99, 4 p.

Plummer, L.N., Prestemon, E.C., and Parkhurst, D.L., 1994, An interactive code (NETPATH) for modeling net geochemical reactions along a flow path Version 2.0: U.S. Geological Survey Water-Resources Investigations Report 94-4169, Reston, Virginia, 130 p. [Also available at http://wwwbrr.cr.usgs.gov/projects/GWC_coupled/netpath/.]
Pohlmann, K.F., and Alduino, A.J., 1992, Potential sources of error in groundwater sampling at hazardous waste sites: U.S. Environmental Protection Agency, Office of Research and Development, Office of Solid Waste and Emergency Response, Report number EPA/540/S-92/019, 28 p.

Puckett, L.J., 1994, Nonpoint and point sources of nitrogen in major watersheds of the United States: U.S. Geological Survey Water-Resources Investigations Report 94-4001, 9 p.

Raynolds, R.G., 2002, Upper Cretaceous and Tertiary stratigraphy of the Denver Basin, Colorado: Rocky Mountain Geology, v. 37, p. 111-134.

Raynolds, R.G.H., Johnson, K.R., Arnold, L.R., Farnham, R.M., Fleming, R.F., Hicks, J.F., Kelley, S.A., Lapey, L.A., Nichols, D.J., Obradovich, J.D., and Wilson, M.D., 2001, The Kiowa core, a continuous drill core through the Denver Basin bedrock aquifers at Kiowa, Elbert Country, Colorado: U.S. Geological Survey Open-File Report 01-185.

Robson, S.G., 1983, Hydraulic characteristics of the principal bedrock aquifers in the Denver Basin, Colorado: U.S. Geological Survey Hydrologic Investigations Atlas HA-659, scale 1:500,000, 3 sheets.

Robson, S.G., 1987, Bedrock aquifers in the Denver Basin, Colorado-A quantitative water-resources appraisal: U.S. Geological Survey Professional Paper 1257, 73 p.

Robson, S.G., 1989, Alluvial and bedrock aquifers of the Denver Basin-Eastern Colorado's dual groundwater resource: U.S. Geological Survey Water-Supply Paper 2302, $40 \mathrm{p}$.

Robson, S.G., 1996, Geohydrology of the shallow aquifers in the Denver metropolitan area, Colorado: U.S. Geological Survey Hydrologic Investigations Atlas HA-736, scale $1: 50,000,5$ sheets.

Robson, S.G., and Banta, E.R., 1993, Data from core analyses, aquifer testing, and geophysical logging of Denver Basin bedrock aquifers at Castle Pines, Colorado: U.S. Geological Survey Open-File Report 93-442, 94 p.

Robson, S.G., and Banta, E.R., 1995, Arizona, Colorado, New Mexico, Utah, segment 2 of Ground water atlas of the United States: U.S. Geological Survey Hydrologic Investigations Atlas HA-730C, $32 \mathrm{p}$.

Robson, S.G., and Romero, J.C., 1981a, Geologic structure, hydrology, and water quality of the Arapahoe Aquifer in the Denver Basin, Colorado: U.S. Geological Survey Hydrologic Investigations Atlas HA-647.

Robson, S.G., and Romero, J.C., 1981b, Geologic structure, hydrology, and water quality of the Denver Aquifer in the Denver Basin, Colorado: U.S. Geological Survey Hydrologic Investigations Atlas HA-646. 
Robson, S.G., and Romero, J.C., 1981c, Geologic structure, hydrology, and water quality of the Dawson Aquifer in the Denver Basin, Colorado: U.S. Geological Survey Hydrologic Investigations Atlas HA-643.

Robson, S.G., Romero, J.C., and Zawistowski, S., 1981, Geologic structure, hydrology, and water quality of the Arapahoe aquifer in the Denver Basin, Colorado: U.S. Geological Survey Hydrologic Investigations Atlas HA-646, scale 1:500,000, 3 sheets.

Robson, S.G., VanSlyke, George, and Graham, G., 1998, Structure, outcrop, and subcrop of the bedrock aquifers along the western margin of the Denver Basin, Colorado: U.S. Geological Survey Hydrologic Investigations Atlas HA-742, scale 1:50,000, 5 sheets.

Robson, S.G., Wacinski, A., Zawistowski, S., and Romero, J.C., 1981, Geologic structure, hydrology, and water quality of the Laramie-Fox Hills Aquifer in the Denver Basin, Colorado: U.S. Geological Survey Hydrologic Investigations Atlas HA-650.

Romero, J.C., 1976, Ground-water resources of the bedrock aquifers of the Denver Basin: Colorado Division of Water Resources Report, 109 p.

Sandstrom, M.W., Stroppel, M.E., Foreman, W.T., and Schroeder, M.P., 2001, Methods of analysis by the U.S. Geological Survey National Water Quality LaboratoryDetermination of moderate-use pesticides and selected degradates in water by $\mathrm{C}-18$ solid-phase extraction and gas chromatography/mass spectrometry: U.S. Geological Survey Water-Resources Investigations Report 01-4098, $70 \mathrm{p}$.

Schlesinger, W.H., Reckhow, K.H., and Bernhardt, E.S., 2006, Global change-The nitrogen cycle and rivers: Water Resources Research, v. 42, W03S06, doi:10.1029/ 2005WR004300.

Schlosser, P., Stute, M., Dorr, H., Sonntag, C., and Munnich, K.O., 1988, Tritium $/{ }^{3} \mathrm{He}$ dating of shallow groundwater: Earth and Planetary Science Letters, v. 89, p. 353-362.

Scoffin, T.P., 1987, An introduction to carbonate sediments and rocks: Chapman and Hall/Methuen, Inc., New York, N.Y., $274 \mathrm{p}$.

Scott, G.R., 1963a, Quaternary geology and geomorphic history of the Kassler quadrangle, Colorado: U.S. Geological Survey Professional Paper 421-A, 70 p.

Scott, G.R., 1963b, Bedrock geology of the Kassler quadrangle, Colorado: U.S. Geological Survey Professional Paper 421-B, 70 p.

Scott, J.C., 1990, Computerized stratified random siteselection approaches for design of a ground-water-quality sampling network: U.S. Geological Survey Water-Resources Investigations Report 90-4101, 114 p.
Seiler, R.L., Skorupa, J.P., and Peltz, L.A., 1999, Areas susceptible to irrigation-induced selenium contamination of water and biota in the western United States: U.S. Geological Survey Circular 1180, 36 p.

Smith, R.O., Schneider, P.A., Jr., and Petri, L.R., 1964, Ground-water resources of the South Platte River Basin in western Adams and southwestern Weld Counties, Colorado: U.S. Geological Survey Water-Supply Paper 1658, 132 p.

Soister, P.E., 1978a, Geologic setting of coal in Denver Basin: Rocky Mountain Association of Geologists 1978 Symposium, p. 183-185.

Soister, P.E., 1978b, Stratigraphy of uppermost Cretaceous and lower Tertiary rocks of the Denver Basin: Rocky Mountain Association of Geologists 1978 Symposium, p. 223-230.

Sosebee, J.B., Jr., Geiszler, P.C., Winegardner, D.L., and Fisher, C.R., 1983, Contamination of groundwater samples with poly (vinyl chloride) adhesives and poly (vinyl chloride) primer from monitor wells, in Conway, R.A., and Gulledge, W.P., eds., Hazardous and industrial solid waste testing, 2nd Symposium, January 28-29, 1982: American Society for Testing and Materials (ASTM) Technical Publication 805, p. 38-50.

Spalding, R.F., and Exner, M.E., 1993, Occurrence of nitrate in ground water-A review: Journal of Environmental Quality, v. 22, p. 392-402.

Steele, G.V., Cannia, J.C., Sibray, S.S., and McGuire, V.L., 2005, Age and quality of ground water and sources of nitrogen in the surficial aquifers in Pumpkin Creek Valley, western Nebraska, 2000: U.S. Geological Survey Scientific Investigations Report 2005-515, 68 p.

Stuiver, M., and Polach, H.A., 1977, Discussion-Reporting of ${ }^{14} \mathrm{C}$ data: Radiocarbon, v. 19, p. 353-363.

Thatcher, L.L., Janzer, V.J., and Edwards, K.W., 1977, Methods for determination of radioactive substances in water and fluvial sediments: U.S. Geological Survey Techniques of Water-Resources Investigations, book 5, chap. A5, p. 79-81.

Thompson, G.M., and Hayes, J.M., 1979, Trichlorofluoromethane in groundwater-A possible tracer and indicator of groundwater age: Water Resources Research, v. 14, no. 3, p. 546-554.

Toccalino, P.L., 2007, Development and application of healthbased screening levels for use in water-quality assessments: U.S. Geological Survey Scientific Investigations Report 2007-5106, 12 p.

Toccalino, P.L., and Hopple, J.A., 2010, The quality of our Nation's waters-Quality of water from public-supply wells in the United States, 1993-2007-Overview of major findings: U.S. Geological Survey Circular 1346, 58 p. 
Toccalino, P.L., Norman, J.E., Booth, N.L., Thompson, J.L., and Zogorski, J.S., 2012, Health-based screening levels-Benchmarks for evaluating water-quality data: U.S. Geological Survey, National Water-Quality Assessment Program, accessed August 1, 2013, at http://water.usgs.gov/ nawqa/HBSL/.

Toccalino, P.L., Norman, J.E., Phyllips, R.H., Kauffman, L.J., Stackelberg, P.E., Nowell, L.H., Krietzman, S.J., and Post, G.B., 2004, Application of health-based screening levels to groundwater quality data in a state-scale pilot effort: U.S. Geological Survey Scientific Investigations Report 20045174, 64 p.

Trimble, D.E., 1980, The geologic story of the Great Plains: U.S. Geological Survey Bulletin 1493, 55 p.

Tweto, Ogden, 1979, Geologic map of Colorado: U.S. Geological Survey Special Geologic Map, 1 sheet.

U.S. Census Bureau, 2012, Population estimates: Accessed December 31, 2012, at http:/www.census.gov/population/ metro/data/.

U.S. Environmental Protection Agency, 2004a, Drinking water health advisory for manganese: EPA-822-R-04-003, 55 p., accessed October 7, 2011, at http://www.epa.gov/ogwdw/ $\mathrm{ccl} / \mathrm{pdfs} /$ reg_determine1/support_cc1_magnese_dwreport. pdf.

U.S. Environmental Protection Agency, 2004b, State actions banning MTBE (Statewide): EPA420-B-04-009, 3 p., accessed December 16, 2011, at http://www.epa.gov/ mtbe/420b04009.pdf.

U.S. Environmental Protection Agency, 2011, Drinking water contaminants: Accessed June 22, 2011, at http://water.epa. gov/drink/contaminants/index.cfm.

U.S. Environmental Protection Agency, 2013, Proposed radon in drinking water regulation: Accessed January 30, 2013, at http://water.epa.gov/lawsregs/rulesregs/sdwa/radon/ regulations.cfm.

U.S. Geological Survey, variously dated, National field manual for the collection of water-quality data: U.S. Geological Survey Techniques of Water-Resources Investigations. [Also available at http://water.usgs.gov/owq/FieldManual/.]

U.S. Geological Survey, 2001, National Land Cover Database 2001: Accessed December 2, 2009, at http://www.mrlc.gov/ nlcd.php.

U.S. Geological Survey, 2012, USGS Water Data for Colorado: National Water Information System (NWIS). [Also available at http://waterdata.usgs.gov/co/nwis.]

U.S. Geological Survey Reston Chlorofluorocarbon Laboratory, 2010, The Reston Chlorofluorocarbon Laboratory: accessed November 10, 2010, at http:/water. usgs.gov/lab/.
VanSlyke, George, Romero, J.C., Moravec, G., and Wacinski, A., 1988a, Geologic structure, sandstone/siltstone isolith, and location of non-tributary ground water for the Dawson aquifer, Denver Basin, Colorado: Colorado Division of Water Resources, Denver Basin Atlas no. 1 (DBA-1), 3 pls.

VanSlyke, George, Romero, J.C., Moravec, G., and Wacinski, A., 1988b, Geologic structure, sandstone/siltstone isolith, and location of non-tributary ground water for the Denver aquifer, Denver Basin, Colorado: Colorado Division of Water Resources, Denver Basin Atlas no. 2 (DBA-2), 3 pls.

VanSlyke, George, Romero, J.C., Moravec, G., and Wacinski, A., 1988c, Geologic structure, sandstone/siltstone isolith, and location of non-tributary ground water for the Arapahoe aquifer, Denver Basin, Colorado: Colorado Division of Water Resources, Denver Basin Atlas no. 3 (DBA-3), 3 pls.

VanSlyke, George, Romero, J.C., Moravec, G., and Wacinski, A., 1988d, Geologic structure, sandstone/siltstone isolith, and location of non-tributary ground water for the LaramieFox Hills aquifer, Denver Basin, Colorado: Colorado Division of Water Resources, Denver Basin Atlas no. 4 (DBA-4), 3 pls.

Walvoord, M.A., Philips, F.M., Stonestrom, D.A., Evans, R.D., Hartsough, P.C., Newman, B.D., and Striegl, R.G., 2003, A reservoir of nitrate beneath desert soils: Science, v. 302, p. 1021-1024.

Waskom, R., and Neibauer, M., 2010, Water conservation in and around the home: Colorado State University Extension, Consumer Series/Housing Fact Sheet No. 9.952, accessed May 1, 2011, at http://www.ext.colostate.edu/pubs/ consumer/09952.html.

Weimer, R.J., 1973, Guide to uppermost Cretaceous stratigraphy, Central Front Range, Colorado-Deltaic sedimentation, growth faulting and early Laramide crustal movement: The Mountain Geologist, v. 10, no. 3, p. 53-97.

Weimer, R.J., and LeRoy, L.W., 1987, Paleozoic-Mesozoic section-Red Rocks Park, I-70 road cut, and Rooney Road, Morrison area, Jefferson County, Colorado: Geological Society of America Centennial Field Guide, Rocky Mountain Section, p. 315-319.

Weres, Oleh, Bowman, H.R., Goldstein, Aaron, Smith, E.C., and Tsao, Leon, 1990, The effect of nitrate and organic matter upon mobility of selenium in groundwater and in a water treatment process: Water, Air, and Soil Pollution, v. 49 , p. 251-272.

Wiedemeier, T.H., Rifai, H.S., Newell, C.J., and Wilson, J.T., 1999, Natural attenuation of fuels and chlorinated solvents in the subsurface: New York, John Wiley and Sons, Inc., $617 \mathrm{p}$.

Winter, T.C., Harvey, J.W., Franke, O.L., and Alley, W.M., 1998, Ground water and surface water-A single resource: U.S. Geological Survey Circular 1139, 79 p. 
Wright, W.G., 1999, Oxidation and mobilization of selenium by nitrate in irrigation drainage: Journal of Environmental Quality, v. 28, p. 1182-1187.

Wylie, B.K., Wagner, D.G., Hoffer, R.M., Maxwell, S., and Shaffer, M.J., 1993, Spatial distribution of nitrate leaching 'hot spots' and nitrate contributions to the South Platte River Basin aquifers: Fort Collins, Colorado Water Resources Research Institute Report 181, 12 p.

Zaugg, S.D., Sandstrom, M.W., Smith, S.G., and Fehlberg, K.M., 1995, Methods of analysis by the U.S. Geological Survey National Water Quality Laboratory-Determination of pesticides in water by $\mathrm{C}-18$ solid-phase extraction and capillary-column gas chromatography/mass spectrometry with selected-ion monitoring: U.S. Geological Survey Open-File Report 95-181, 60 p.
Zielinski, R.A., Asher-Bolinder, Sigrid, and Meier, A.L., 1995, Uraniferous waters of the Arkansas River valley, Colorado, U.S.A.-A function of geology and land use: Applied Geochemistry, v. 10, p. 133-144.

Zogorski, J.S., Carter, J.M., Ivahnenko, Tamara, Lapham, W.W., Moran, M.J., Rowe, B.L., Squillace, P.J., and Toccalino, P.L., 2006, The quality of our Nation's watersVolatile organic compounds in the Nation's ground water and drinking-water supply wells: U.S. Geological Survey Circular 1292, 101 p.
Publishing support provided by Lafayette Publishing Service Center

Information regarding water resources in Colorado is available at http://co.water.usgs.gov/ 

